Norway spruce in German low mountain ranges morphological distinctiveness and genetic adaptation of high elevation provenances

\author{
Dissertation \\ to attain the doctoral degree (Dr. forest.) \\ of the Faculty of Forest Sciences and Forest Ecology \\ Georg-August-Universität Göttingen \\ Submitted by \\ Oliver Caré
}

born in Munich, Germany

Göttingen, July 2020 
1. Referee: PD Dr. Ludger Leinemann

2. Referee: Prof. Dr. Niko Balkenhol

Date of oral examination: $27^{\text {th }}$ of October 2020 
"On silent days I hear you whisper

In the wind and in the storm

Hold on to what is sacred to you

Hold it close and don't let go"

Epicon

From the album: Hell in Eden

By: Diary of Dreams

2017 


\section{Abstract}

The natural range of Norway spruce (Picea abies [L.] KARST.) populations in Germany are the low mountain ranges. But in the last decades and centuries anthropogenic stand establishment highly increased the area covered by Norway spruce. This happens mostly in regions beyond their natural growing range. The used reproduction material often originates from allochthonous provenances. This leads not only to a change in the species composition of German forests, but likely alter genetic composition of spruce populations. Therefore, planted spruce stands are potentially maladapted to their current growing environment.

Under changing climatic conditions, it is expected that future suitable regions for spruce forestry are restricted to higher elevations, with challenging environmental conditions. Norway spruce provenances, adapted to the harsh mountainous condition, usually show narrower crowns and different branching morphology than provenances from lower elevations. Stands characterised by these morphological traits have nonetheless become rare due to the past anthropogenic replantation with unsuited material. To support silvicultural management of high elevation stands and to preserve and expand adapted populations, information on the morphologic and genetic characteristics of provenances is required.

Stand pairs in the regions of the Thuringian Forest, the Ore mountains and the Harz mountains of putative native mountainous and planted Norway spruce stands in comparable altitudes were investigated. In each stand, 200 trees were visually assessed for their crown morphology and sampled for the genetic analyses. Additionally, the relict stand "Schlossbergfichte" in the Thuringian Forest, known for its characteristic high elevation phenotypes, was included with 75 samples.

These samples were investigated by Caré et al. (2018) to assess the neutral genetic differentiation between the stands and quantify morphological differentiation between the putative provenances. Between the stands an overall low differentiation $\left(F_{S T}=0.002-0.007 ; G^{\prime \prime}{ }_{S T}\right.$ $=0.002-0.030$ ) based on the analysis of 11 neutral SSR (simple sequence repeat) markers was found. Likely attributed to the high long distant geneflow commonly reported for Norway spruce. Nevertheless, both the stands from the Harz mountains as well as the "Schlossbergfichte" were slightly differentiated from all other populations. Indicating in the first case restricted geneflow by the small isolation by distance effect and usage of local material in case of the planted stand. In the second case, that the relict characteristics of the stand is reflected in its genepool. Contrasting, the provenances were highly differentiated for crown morphology traits $\left(P_{S T}=0.952-0.989\right)$. This contrast between low neutral genetic but high morphological differentiation, indicates natural selection in adaptive genes which are involved in the expression of crown phenotypes. 
To analyse the influence of selection, a subsequent analysis at 44 SNPs (single nucleotide polymorphisms) in putative adaptive candidate genes was conducted (Caré et al. 2020a). The selected SNPs had previously been identified to be involved in phenological adaptation, the photoperiodic pathway, local adaptation, and stress response in Picea ssp. By a combination of differentiation- and regression-based approaches, six SNPs in three genes (APETALA 2-like 3 [AP2L3], one GIGANTEA [GI] gene, and a mitochondrial transcription termination factor $[m T E R F])$ with a high significant relationship between the allele frequencies and the variation of the crown shape were identified. With lower statistical support five SNPs in three genes (D6-protein kinase-like 2 [D6PKL2], one gene with unknown function, and a pseudo-response regulator 1 [PRR1]) exhibit a possible association to the crown shape. These results underline the important role of circadian clock genes (GI6/PRR1) in local adaptation and support the assumption of the adaptive differences of provenances expressing contrasting crown shape. Thus, the crown shape is suitable as a selection and assessment criteria in elevated stands, also reflecting adaptive genetic attributes.

As shown by this specific adaptedness, the rare local adapted high elevation stands are valuable for the conservation of genetic resources and utilised to produce seed material. With the large proportion of planted allochthon stands in mountainous regions, it is of further interest to quantify the extend of external pollen contribution to the progeny of native stands. In a mating system analysis, conducted in the Thuringian forest, Caré et al. (2020b) estimated a high external pollen contribution of at least $70 \%$. Combined with the demonstrated adaptive genetic difference, presumably this introgressive gene-flow alters the genetic composition of the autochthonous stands' progeny. Additionally, a relationship between germination percentage and effective pollen population size and relatedness of half-sib families was found. Likely linked to diversity differences of the individual pollen clouds, this result indicates a genetic effect on fitness in an early ontogenetic stage. Noteworthy, the progenies from trees in the central part of the sample area have in general a lower contribution from external pollen $(\bar{x} \approx 63 \%)$ than those from edge trees $(\bar{x} \approx 78 \%)$. This suggests, that seed should preferably be harvested from central trees when maintaining high numbers of seed trees is possible. Further studies are nevertheless needed to assess the fluctuation between years and sites for precise recommendations. 


\section{Zusammenfassung}

Die mittleren und höheren Lagen stellen die natürliche Verbreitung der Fichte (Picea abies [L.] KARST.) in Deutschland dar, jedoch erweiterten Pflanzungen ab dem 18. Jahrhundert diese Verbreitung massiv. Durch einen ausgeprägten Saatguthandel kann bei vielen heutigen Beständen von einer gebietsfremden Herkunft ausgegangen werden. Diese Maßnahmen prägten nicht nur das Erscheinungsbild der Wälder bis heute, auch von einem Einfluss auf die genetische Zusammensetzung der Fichtenbestände ist auszugehen.

Risiken der Klimaveränderung beschränken nachhaltige Forstwirtschaft mit der Fichte zukünftig auf die Hochlagen. Fichtenherkünfte, die an das harte Klima der Hochlagen angepasst sind, zeigen eine typischerweise schlanke Kronenform. Bestände mit solcher Ausprägung sind jedoch durch die historischen Aufforstungen selten geworden. Um die waldbauliche Steuerung und den Erhalt solcher Bestände zu fördern, ist ein fundierte Wissensbasis $\mathrm{zu}$ den morphologischen und genetischen Unterschieden der verschiedenen Herkünfte unumgänglich.

In dem Mittelgebirgsregionen des Thüringer Waldes, des Erzgebirges und des Harzes wurden daher, vermeintlich gebietsfremde und gebietsheimische, Fichtenbestände in vergleichbarer Höhenlage untersucht. Je Region wurden Bestandespaare lokaler und gebietsfremder Herkunft ausgewählt und 200 Altbäume je Bestand beprobt und morphologisch charakterisiert. Zusätzlich wurde der Reliktbestand "Schlossbergfichte" im Thüringer Wald mit 75 Bäumen in die Untersuchungen einbezogen. Dieser ist für seine charakteristischen schlanken Hochlagenfichten bekannt.

Anhand dieser Proben wurde von Caré et al. (2018) die neutrale genetische Differenzierung der Bestände untersucht und Unterschiede zwischen den Herkünften anhand morphologischer Kronenmerkmale quantifiziert. Zwischen den Beständen wurde eine geringe neutrale genetische Differenzierung an 11 Mikrosatelliten $\left(F_{S T}=0.002-0.007 ; G^{\prime \prime}{ }_{S T}=0.002-\right.$ 0.030) festgestellt. Hierfür wahrscheinlich ursächlich ist der für die gemeine Fichte bekannte und ausgeprägte Genfluss über große Distanzen. Dennoch konnte sowohl für beide Populationen aus dem Harz als auch bei der "Schlossbergfichte“ eine geringe, aber deutliche, Differenzierung zu den übrigen Populationen gezeigt werden. Für die Bestände im Harz deutet dies auf eine räumliche Isolation durch die Verwendung lokalen Pflanzenmaterials hin. Die Schlossbergfichte zeigt ausgeprägte variable genetische Strukturen eines Reliktvorkommens. Kontrastierend, zeigten die angenommenen Herkünfte starke phänotypische Differenzierung der Kronenmorphologie $\left(P_{S T}=0.952-0.989\right)$. Natürliche Selektion in adaptiv relevanten Genen, verantwortlich für die Ausprägung der Kronenmorphologie, ist daher anzunehmen.

Zur Analyse von selektiven Effekten wurde im Folgenden die Variation anhand 44 Einzelnukleotid-Polymorphismen (SNPs) in putativen Kandidatengenen untersucht (Caré et al. 2020a). 
Die ausgewählten SNPS wurden bereits mit phänologischen Anpassungs- und photoperiodischen Steuerungprozessen, lokaler Anpassung und der Reaktion auf Stress bei Picea ssp. in Verbindung gebracht. Mit einer Kombination aus Differenzierungs- und Regressionsanalysen konnten, mit hoher Signifikanz, die Allelhäufigkeiten an sechs SNPs in drei Genen (APETALA 2-like 3 [AP2L3], GIGANTEA [GI], und mitochondrialer Transkriptionsterminations-faktor [mTERF]) mit der Variation der Kronenform in Zusammenhang gebracht werden. Mit geringerer statistischer Absicherung, zeigten weitere fünf SNPs in drei Genen (D6-ähnliche Proteinkinase 2 [D6PKL2], ein Gen unbekannter Funktion, und ein Pseudo-Response Regulator 1 [PRR1]) eine mögliche Assoziation zur Kronenform. Einerseits bestätig dies die Rolle von Genen der circadianen Uhr (GI/PRR1) in lokalen Anpassungsprozessen, anderseits zeigt es die adaptiven Unterschiede der untersuchten Herkünfte mit verschiedener Kronenmorphologie. Daher spiegelt die Kronenmorphologie adaptiv genetische Merkmale wider und können als Selektions- und Beurteilungskriterium in Hochalgenbeständen genutzt werden.

Mit ihrer spezifischen Angepasstheit stellen diese seltenen autochthonen Hochlagenbestände aus Sicht der Generhaltung und der Saatgutgewinnung wertvolle Genressourcen dar. Jedoch ist die Quantifizierung das Ausmaß von externem Polleneinfluss auf die Nachkommenschaft der gebietsheimischen Bestände von Bedeutung, da in den Hochlagen ein großer Anteil gepflanzte Bestände gebietsfremder Herkunft vorkommt. In der Untersuchung des Paarungssystems eines autochthonen Hochlagenbestand im Thüringer Wald schätzten Caré et al. (2020b) dabei den Fremdpollenbeitrag zur Nachkommenschaft auf mindesten 70 \%. Mit großer Wahrscheinlichkeit stammen wesentliche Anteile des externen Pollens aus Beständen ohne lokale Angepasstheit. Damit ist von einem negativen Effekt auf das, in angepassten Beständen produzierte, Saatgut auszugehen. Auch ein Einfluss auf die genetischen Strukturen über mehrere Generationen scheint hierdurch wahrscheinlich. Weiterhin konnten Hinweise auf den Einfluss der Genetik auf die Leistungsfähigkeit in frühe ontogenetische Phase in Form der Keimprozente, gefunden werden. Dies ließ sich aus dem signifikanten Zusammenhang zwischen Keimprozenten in den Halbgeschwister-Familien und deren geschätzter Verwandtschaft bzw. effektiver Populationgröße der Pollenwolke ableiten, welches wahrscheinlich auf Unterschiede in der genetischen Diversität der Pollenwolke zurückgeführt werden kann. Beachtenswert ist, dass der geschätzten Fremdpollenanteil in der Nachkommenschaft bei Mutterbäumen im Bestandeszentrum geringer ist $(\bar{x} \approx 63 \%)$ als es der bei Randbäumen ist $(\bar{x} \approx 78 \%)$. Möglicherweise ist daher die Ernte von Saatgut in einer Kernzone anzustreben, wenn trotzdem eine hohe Anzahl bäume beerntet werden kann. Weitere Studien zur jährlichen und standortabhängigen Fluktuation sind jedoch für die Ableitung präziser Handlungsempfehlungen durchzuführen. 


\section{Table of contents}

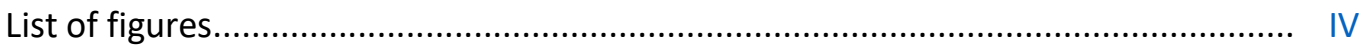

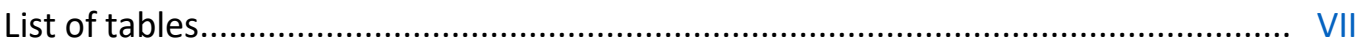

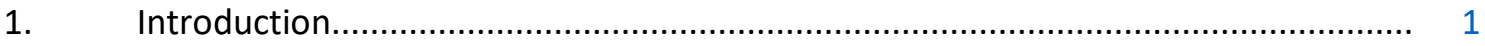

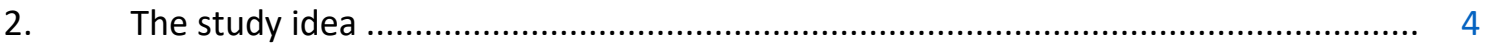

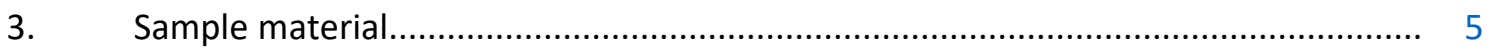

4. Overview of the project results, discussions, and additional remarks................... 6

4.1. Neutral genetic and morphological differentiation of Norway spruce stands in the German uplands (presented in Caré et al. 2018)........................................................ 6

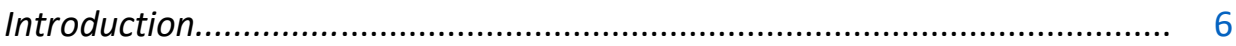

Materials and methods ............................................................................ 7

Results and discussion ........................................................................... 7

4.2. Remarks to Caré et al. 2018............................................................................ 9

4.3. Search for signs of genetic adaptation between morphological differentiated trees (presented in Caré et al. 2020a)..................................................................... 12

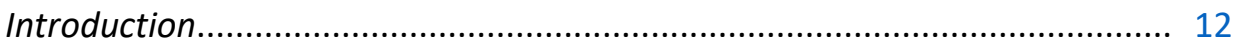

Materials and methods.................................................................... 12

Results and discussion ............................................................................ 13

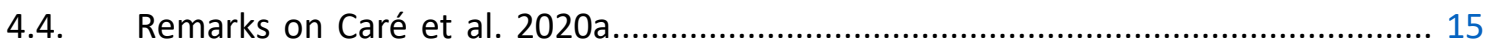

4.5. Mating system analysis in a native Norway spruce stand estimated high levels of immigrant geneflow (presented in Caré et al. 2020b)............................................... 18

Introduction ............................................................................................. 18

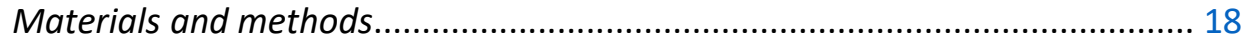

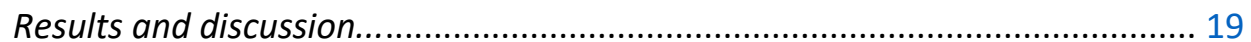

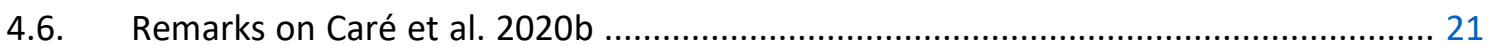

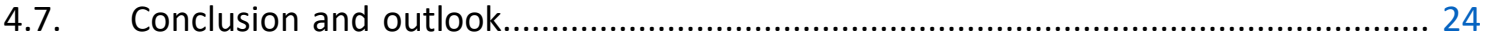

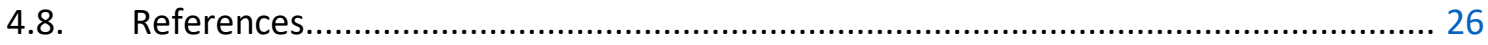

5. Chapter I-High morphological differentiation in crown architecture contrasts with low population genetic structure of German Norway spruce stands.................................. 33

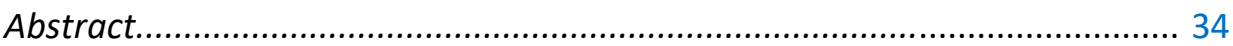

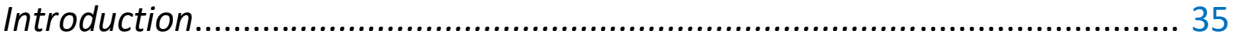

Materials and methods........................................................................ 36

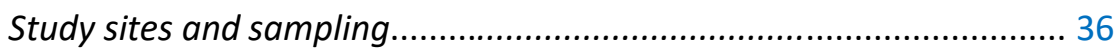

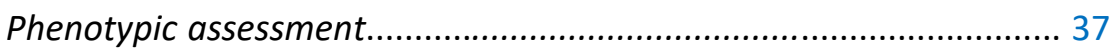


Marker analysis.

DNA extraction

Phenotypic variation................................................................ 39

Genetic variation -SSR analyses............................................ 40

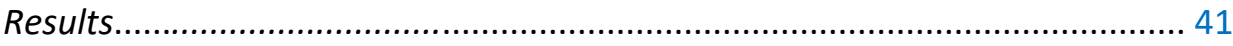

Phenotypic differentiation between low and high elevation types..... 41

Genetic variation and differentiation ........................................ 43

Discussion ......................................................................... 46

Autochthonous and allochthones stands................................. 46

Phenotypic differentiation....................................................... 46

Genetic variation and differentiation...................................... 47

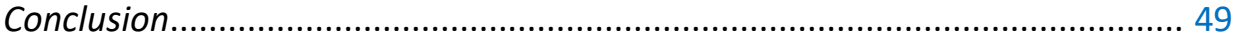

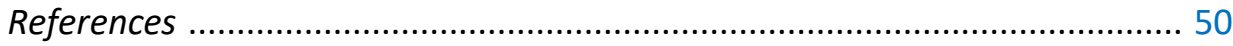

5.1. Chapter I - Supplementary Materials .......................................................... 57

6. Chapter II - Crown morphology in Norway spruce (Picea abies [KARST.] L.) as adaptation to mountainous environments is associated with single nucleotide polymorphisms (SNPs) in genes regulating seasonal growth rhythm....................................... 66

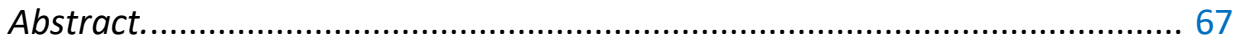

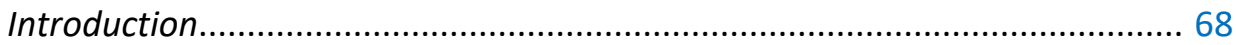

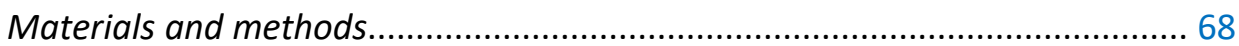

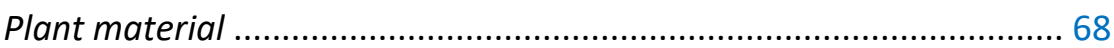

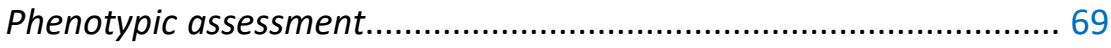

SNP selection and genotyping ................................................ 69

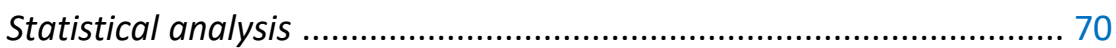

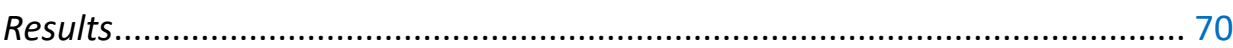

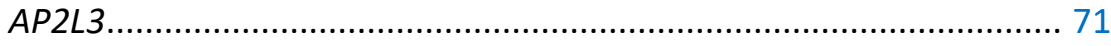

GI.................................................................................... 71

mTERF ........................................................................ 71

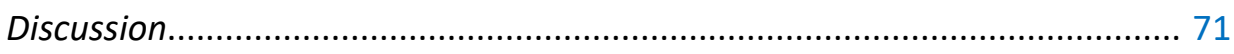

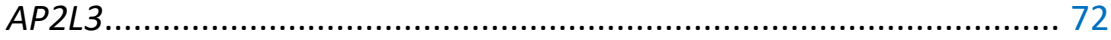

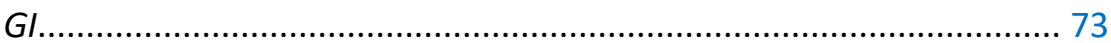

mTERF .......................................................................... 74

Genetic structure and possible evolutionary forces.......................... 74

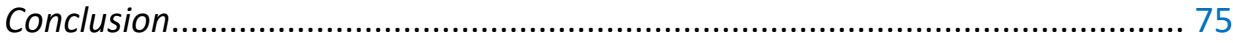


6.1. Chapter II -Supplementary Materials 1: Information on the SNPs ............................ 80

6.2. Chapter II - Supplementary Materials 2: Figures and tables ..................................... 81

6.3. Chapter II-Supplementary Materials 3: Additional results and discussion on nominal significant SNPs

PRR1

D6PKL2

UF.

7. Chapter III - Mating system in a native Norway spruce (Picea abies [L.] KARST.) stand Effective population size and relatedness show the tendency of an association with the germination percentage of single tree progenies.

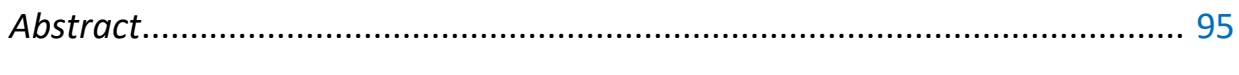

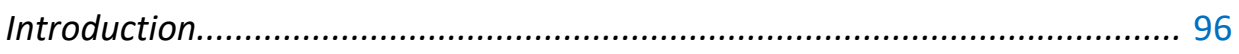

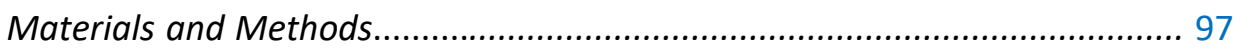

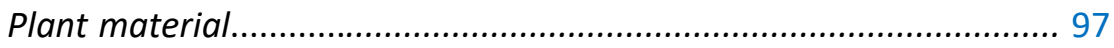

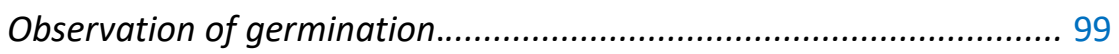

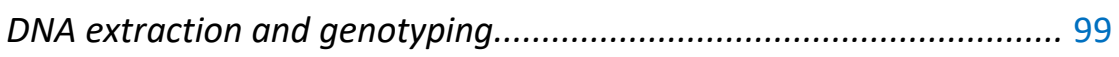

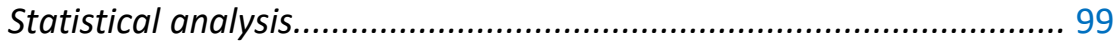

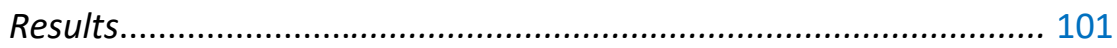

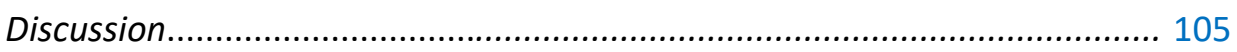

Germination and relatedness......................................................... 105

Distance and distribution.................................................................. 107

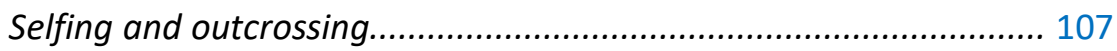

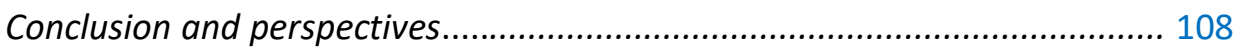

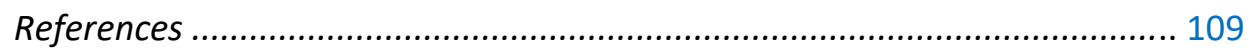

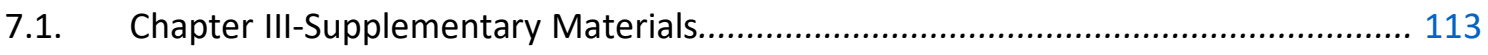

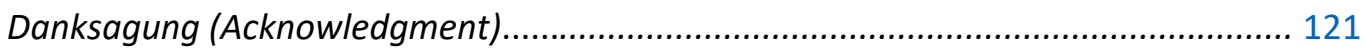

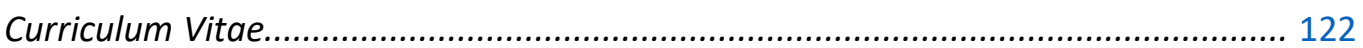




\section{List of figures}

Recapitulation of the project results, discussions and additional remarks

Figure 1. Norway spruce trees representing a) the "lowland" morphotype with damaged crown and subsequent forking, b) mountainous morphotype with downward facing branching and narrow appearance.

Figure 2. Spatial distribution of crown shape in the putative autochthonous stand in the Ore mountains Saxony.

Figure 3. Preliminary and exemplary illustration of the estimated proportion of local pollen contribution to the progeny.

\section{Chapter I - High morphological differentiation in crown architecture contrasts with low population genetic structure of German Norway spruce stands}

Figure 1. Relative frequencies of the assessed phenotypic traits (overall crown shape, angle of the first order branches, second order branching pattern, occurrence of crown damage, and occurrence of forking) in the studied stands.

Figure 2. Discriminant analysis of principal component (DAPC) [65] on multivariate phenotypic data.

Figure 3. Spatial principal component analysis [66] based on the allele data, reflecting low spatial genetic differentiation for the SSR loci.

Figure 4. Clustering result based on the STRUCTURE [96] analysis and displayed as the average over the 15 runs obtained from CLUMPAK [100].

\section{Chapter I - Supplementary Materials}

Figure S1 a-d. Overview map (a) and map sections of the stand locations. Harz region (b) with the northern high elevation (HE) and southern low elevation (LE) stand. Thuringian forest (c) with the northern relict stand "Schlossbergfichte", the southern LE stand and the more eastern HE stands. Ore mountains in Saxony (d) with the western HE stand and eastern LE stand. ...... 59

Figure S2. Schematic presentation of the three main crown architectural types. From left to right, lowland combe type, intermediate brush type and narrow high elevation plate type. .... 60

Figure S3. Relationship of phenotypic divergence in a trait across populations $\left(P_{S T}\right)$ [60-62] over the ratio of the total variance explained by additive genetic effects across populations and the narrow sense heritability $\left(c / h_{2}\right)$.

Figure S4. Corresponding $p$ - value of the log likelihood ratio test on the deviation from HWE of each locus genotyped in each population sampled.

Figure S5. Estimation of the null allele frequency at each locus in each population separately. Average of maximum likelihood estimation expectation maximisation [71] in genepop [72] and ML estimation in ML-Nullfreq [73].

Figure S6. Heatmaps displaying the standardizes index of association $\bar{r}_{d}$ [69] for pairwise loci comparison for each stand separately.

Figure S7. Detection of outlier loci in LOSITAN [82] exploring the relationship between $F_{S T}$ and $H_{e}$ among populations by permutations.

Figure S8. Directional relative migration network [85] based on $G_{S T}$ [86] of potential allochthones and autochthones populations. 
Figure S9 (a\&d). Detection of the number of clusters K according to a) DeltaK [101], the b) loglikelihood probability of $K(L(K))$ and the corresponding c) first and d) second order change of $L(K)$ [96] calculated in STRUCTURE HARVESTER [102].

Figure S10. Major modes of cluster results from $K 2$ to 12 of STRUCTURE [96] analysis summarised in CLUMPAK [100]. For each $K$ the major mode is given indication the number of runs and der mean similarity of the summarisation output as well as the mean In probability of the mode. 65

Chapter II - Crown morphology in Norway spruce (Picea abies [KARST.] L.) as adaptation to mountainous environments is associated with single nucleotide polymorphisms (SNPs) in

Figure 1. Frequency of crown phenotypes among a) all genotyped Norway spruce trees, and b) within each region.

Figure 2. Nominal $\log _{10}(p)$ values of the association analysis based on GLM analyses implemented in TASSEL 5.0 (Bradbury et al. 2007).

Figure 3. Frequency of genotypes at the two Gigantea genes SNPs a) G/6-1089 and b) G/6-1207 in the three phenotypic groups of main crown trait (narrow, intermediate, and broad) for the pooled dataset.

\section{Chapter II -Supplementary Material 2: Figures and tables}

Figure S1. Map section of central to south-eastern Germany indicating the stand locations as coloured points with corresponding abbreviations as high elevation type (HE), low elevation type (LE), "Schlossbergfichte" (SBF) followed by region Harz Mountains (H), Thuringian Forest (T) and Ore Mountains/ Saxony (S).

Figure S2. Clustering result based on the STRUCTURE (Pritchard et al. 2000) analysis of 11 SSR markers.

Figure S3. Nominal $p$-values of allelic and genotypic complementary compositional differentiation $\delta_{S D}$ calculated using Differlnt (Gillet 2013) between phenotypic groups of narrow, intermediate and broad shaped trees.

Figure S4. Nominal p-values of the association analysis based on the GLM implemented in the R-package "SNPassoc" 1.9-2 (Gonzalez et al. 2007) for each SNP alphabetically ordered along the $x$-axis with corresponding logarithmic $p$-values on the $y$-axis for four colour-coded datasets Harz, Saxonian, Thuringian, and pooled.

Figure S5. The outlier SNPs detected by LOSITAN (Antao et al. 2008) for the groups of narrow, intermediate and broad crowned trees.

Figure S6. Nominal $p$-values of the association analysis based on the GLM implemented in TASSEL 5.0 (Bradbury et al. 2007) for the (a) pooled, (b) Harz, (c) Saxonian and (d) Thuringian datasets for each SNP alphabetically ordered along the $x$-axis with corresponding $p$-values on the $y$-axis. 86

Figure S7. Nominal p-values of the association analysis based on the GLM implemented in the R-package "SNPassoc" 1.9-2 (Gonzalez et al. 2007) for the (a) pooled, (b) Harz, (c) Saxonian and (d) Thuringian datasets for each SNP alphabetically ordered along the $x$-axis with corresponding p-values on the $y$-axis.

Figure S8. Frequency distribution of SNP genotypes in phenotypic groups of selected loci and datasets (a-u). 
Chapter III- Mating System in a Native Norway Spruce (Picea abies [L.] KARST.) StandRelatedness and Effective Pollen Population Size Show an Association with the Germination

Figure 1. (a) Map of the 200 genotyped adult trees (green dots) including 21 seed-sampled mother trees labelled by numbers corresponding to the half-sib family numbers in Table 1 and depicted by yellow cross symbols over green dots. Coordinates are given in WGS 84 (EPSG: 4326). Topographic map at 1:25,000 (b) and 1:1000,000 (c) scales with the stand location indicated by the red dot.

Figure 2. Scatter plot of mean seed germination percentage (x-axis) in 21 half-sib families plotted against the (a) rarefied mean within half-sib family relatedness $\left(r_{(r)}\right)$ or $(b)$ rarefied mean effective pollen population size $\left(N_{e}(P ; r)\right)$ of the half-sib families. 103

Figure 3. Relative frequency of local, within the stand, pollen dispersal in $10 \mathrm{~m}$. distance interval classes and the $0 \mathrm{~m}$ distance class indicating self-fertilisation: (a) dark grey bars represent strict assignments without any mismatch at the genotyped simple sequence repeat (SSR) markers, grey bars represent strict assignments combined with assignments allowing for only one mismatch, where in cases of multiple possible assignments for a seed the nearest pollen donor was considered, and light grey bars represent the same conditions as previous, but mean distance is used in cases of multiple assignments; (b) dark and light grey bars represent assignments made by CERVUS 3.0.7 with $95 \%$ and $80 \%$ confidence, respectively. 105

Figure S1. Quantile-Quantile diagram of the standardized residuals in the linear regression between within half-sib family seed germination rate presented in Figure 3 and a) rarefied mean relatedness or $b$ ) rarefied mean effective pollen population size.

Figure S2. Scatter plot of mean seed germination rate (y-axis) in 21 half-sib families plotted against the a) mean within half-sib family relatedness $(r)$ or b) effective population size $\left(N_{e}\right)$ of the half-sib families. 114

Figure S3. Principal Coordinate Analysis (PCoA) of embryos and also adult trees that represent potential pollen donors in the stand based on the pairwise Hamming distance [25] between them calculated using genotypes of 10 SSR markers. 115

Figure S4. Local pollen dispersal distances and angles of the assignment determined by a) matching the pollen haplotype with the genotyped individuals and b) using Cervus 3.0.7 software. 


\section{List of tables}

Chapter I- High morphological differentiation in crown architecture contrasts with low population genetic structure of German Norway spruce stands

Table 1. Climatological and stand specific data.

Table 2. The assessed phenotypic traits and phenotypes associated with elevation.

Table 3. Details on the SSR (simple sequence repeat) markers used for genotyping.

Table 4. Annotation of the four EST (expressed sequenced tag)-sequences with SSRs (EST-SSRs) used in this study.

Table 5. Summary of basic population genetic parameters.

\section{Chapter I-Supplementary Materials}

Table S1. Concentration $\left(c_{i}\right)$ of each forward and reverse primer in the multiplex reactions and single-plex.

Table S2. Relative frequencies of assessed morphological traits in each stand corresponding to the Figure 1 in the main paper.

Table S3. Hierarchical AMOVA based on the regional and population membership of the individuals. 58

Table S4. Pairwise $F_{S T}$ values between population pairs (bolt) with corresponding $p$-values from 10000 permutations in GenAlEx 6.5 [77].

Table S5. Pairwise $G^{\prime \prime}{ }_{S T}$ values between population pairs in GenAlEx 6.5 [77].

Chapter II - Crown morphology in Norway spruce (Picea abies [KARST.] L.) as adaptation to mountainous environments is associated with single nucleotide polymorphisms (SNPs) in genes regulating seasonal growth rhythm

Table 1. Significant associations between SNP loci and crown phenotype based on the generalized linear model (GLM), $F_{S T}$ outliers, and significant allelic differentiation $\left(\delta_{S D}\right)$ between individuals grouped by their phenotypes, for detected SNPs.

\section{Chapter II - Supplementary Material 2: Figures and tables}

Table S1. Climatological data for the sample stands.

Table S2. Summary of results for the different methods used to detect association between SNP loci and crown phenotype.

Crown morphology in Norway spruce (Picea abies [KARST.] L.) as adaptation to mountainous environments is associated with single nucleotide polymorphisms (SNPS) in genes regulating seasonal growth rhythm

Table 1. Summary of statistical and descriptive parameters for the sampled half-sib families. 98

\section{Chapter III-Supplementary Materials}

Table S1. SSR markers used for genotyping 200 adult trees including 21 seed-collected trees, embryos, and megagametophytes (Caré et al. [17], modified).

Table S2. Concentration $\left(c_{i}, \mu M / \mu l\right)$ of each forward and reverse primer in the multiplex reactions (Caré et al. [17], modified). 
Table S3. PCR touch-down protocol used for amplification of SSR-markers.

Table S4. Pearson's correlation coefficient (PCC) for the comparisons (1 vs. 2) of mean within half-sib families relatedness estimated with different algorithms and reference allele frequencies.

Table S5. Adjusted $\mathrm{R}^{2}$ of linear regressions between the germination percentage and the mean within family relatedness estimated with different algorithms and reference allele frequencies from the original data, excluding half-sib-family 1 due to very limited sample size. 


\section{Introduction}

Conifers are the source for softwood, which is important for timber and pulpwood production. Historically softwood was intensely used as fuel and construction wood, and for charcoal production. Throughout history there are several examples of overexploitations of conifer forests. The Cedar forests in the Middle east where cut, to expand the naval fleet of ancient empires (Khuri et al. 2000). In North America the British empire exploited North American forests for shipbuilding, but also settlement and industrialisation left their traces (MacCleery 1992; Drushka 2003). In Europe the charcoal demand for mining and glassmaking resulted in deforestation in the Carpathians, Romania, European alps, and the low German mountain range (Kirby and Watkins 1998; Oosthoek and Richard 2018). In the area, which is today Germany, the forest state in the beginning of the $19^{\text {th }}$ century can be described as devastated, and fears of a recurrent timber shortage re-emerged. Thus, it is not remarkable, that the transition to the $19^{\text {th }}$ century is also marked by the comprehensive implementation of organized sustainable forest management (Hasel 1993). However, the plantation activities with predominately fast-growing conifers in monocultures, largely spruce and pine, had shaped todays appearance of German forests (Schmidt-Vogt 1977; McGrath et al. 2015).

Norway spruce is still the economically most important tree species in Germany and designated as the "Brotbaum" of German forestry (Spiecker 2000; Knoke 2009; Möhring and Wilhelm 2015). However, pure spruce stands show little resistance and resilience against biotic and abiotic stress, especially beyond their natural range and under changing climatic conditions (Knoke et al. 2008; Zhang et al. 2009). Due to a combination of summer droughts, bark beetle infestations and storms, the economic risk of Norway spruce monocultures has drastically increased in the last decades, leading to the recommendation of a transfer to mixed stands (Spiecker 2000; Knoke 2009). Predictions also show the aggravated difficulties of spruce forestry under future climatic conditions (Hanewinkel et al. 2012).

To increase resilience and resistance of pure spruce stands in suboptimal areas transition to mixed stands with native broadleaved species or transition to broadleaf stands are implemented in several Federal states' silvicultural directives (Bayerische Staatsforsten 2009; Landesforsten Niedersächsische 2011; Landesbetrieb Forst Baden-Württemberg and Ministerium für Ländlichen Raum und Verbraucherschutz Baden-Württemberg 2014; Landesbetrieb HessenForst 2016). Combind with recurring calamities, this leads to a decline of the species share in German forests (Thünen-Institut 2014). Economically, conifer species offer a higher revenue as broadleaf species. 
Thus, introduced conifers like Douglas-fir, Grand-Fir, Hemlock, or the native silver fir are increasingly used to replace spruce forests (Spellmann et al. 2007; Rau and Schönfelder 2008; Vitali et al. 2017). However, reasons to prefer native to non-native tree species are for example the lower investment, better habitat quality, coevolution to native pathogen and mycorrhiza (Brang et al. 2016).

For Norway spruce, the areas with medium to low risk under predicted climate development will be restricted to higher elevations (Spellmann et al. 2007; Kölling et al. 2009; Berendt et al. 2017). Additionally, also from an economic perspective the share of mixed forest with beech and the proportion of beech within the stand will increase compared to the climate average of 1960-90 (Paul et al. 2019). From an ecological perspective and especially in areas where spruce would naturally occur, it is preferable to maintain native species and provenances as genetic resources for in situ conservation (Paul et al. 2010). Thus, the management of spruce stands in suitable regions towards resilient stands shall also be advanced according to the above-mentioned silvicultural directives. Management recommendations in this respect include the species composition, the choice of adapted provenances, the aim of an uneven stand structure and thinning concepts (Paul et al. 2010; Gray and Hamann 2011; Pretzsch et al. 2013; Härt et al. 2015; Möllmann and Möhring 2017).

As outlined, future spruce dominated stands will be more restricted to mountainous region in Germany. Nevertheless, the extensive planting activities in the last centuries, often conducted with material of unknown origin (Paul et al. 2010) and a flourishing seed trade across Europe at the time (Jansen et al. 2017), likely introduced provenances from lowland areas to these regions. Since Norway spruce covers several latitudes and longitudes as well as different altitudinal ranges, different provenances have adapted to a broad variety of environmental conditions. This leaves the questions on the adaptiveness and diversity of current spruce populations in mountainous regions.

In a mountainous environment, selection factors for plant species include frost events, cold temperature, snow load, wind, and a reduced vegetation period (Körner 2003). Comparisons between different provenance have demonstrated, variation in growth and yield, timing of growth cessation, bud set and flushing, susceptibility to frost event and low temperature, and the resistance to snow brakeage (Kalela 1937; Modrzyński and Eriksson 2002; Hannerz and Westin 2005; Chmura 2006; Gömöry et al. 2010; Liesebach et al. 2010). Only little information is available concerning crown characteristic, but an asssociation between narrow symmetrical crown form and tree resistance to brakeage by snow and wind was descirbed (Nykänen et al. 1997). Up to now, only a few provenances, studied in common garden trials, are described in their habitus (Kalela 1937; Liesebach et al. 2010). 
Crown shape in Norway spruce varies gradually between a narrow and a broad shape, with the second order branching pattern exhibits also gradual variation (Priehäusser 1958; Schmidt-Vogt 1977; Gruber 1989, 1993). The narrow crown form with a plate-like branching is more resistant to crown breakage, thus observations of narrow trees are more frequent at higher elevations or snow rich regions (Schmidt-Vogt 1977; Gruber 1993; König 2002; Mátyás 2004; Geburek et al. 2008). Heritability of the crown architecture is assumed (Sylvén 1909; Kiellander 1962; Schmidt-Vogt 1977; Gruber 1989) and recent observations on the trees' slenderness in half-sib families confirmed this assumption (Apostol and Budeanu 2019). Also, some earlier evidence is supporting the high heritability of spruce crown shape (Pöykkö and Pulkkinen 1990).

In mountainous regions in Germany, spruce populations with predominantly narrow crowned trees as well as mainly broad crowned trees occure (Fig.1). The later often showing crown damages, likely caused by snow, due to their unsuitable form (cf. Nykänen et al. 1997). Due to planting activities in the past, the potentially adapted narrow trees are much less frequent (Paul et al. 2010). Crown morphology and phenological traits follow clinal variation, and traits may drastically differ between provenances (Schmidt-Vogt 1977; Leinonen and Hänninen 2002; Chmura 2006; Geburek et al. 2008; Gömöry et al. 2010; Skrøppa and Steffenrem 2020). Provenance differences have been confirmed for putative adaptive genes associated with various traits (Geburek et al. 2007; Chen et al. 2012, 2014; Gyllenstrand et al. 2012; Lind et al. 2014; Di Pierro et al. 2016, 2017). Studies on the association of SNP (single nucleotide polymorphisms) with crown architecture are nonetheless missing.

a)

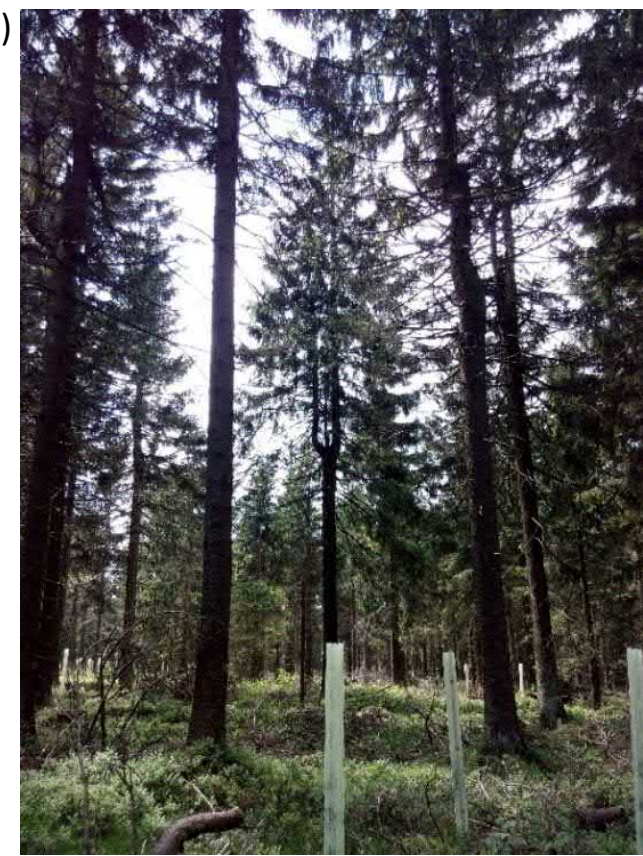

b)

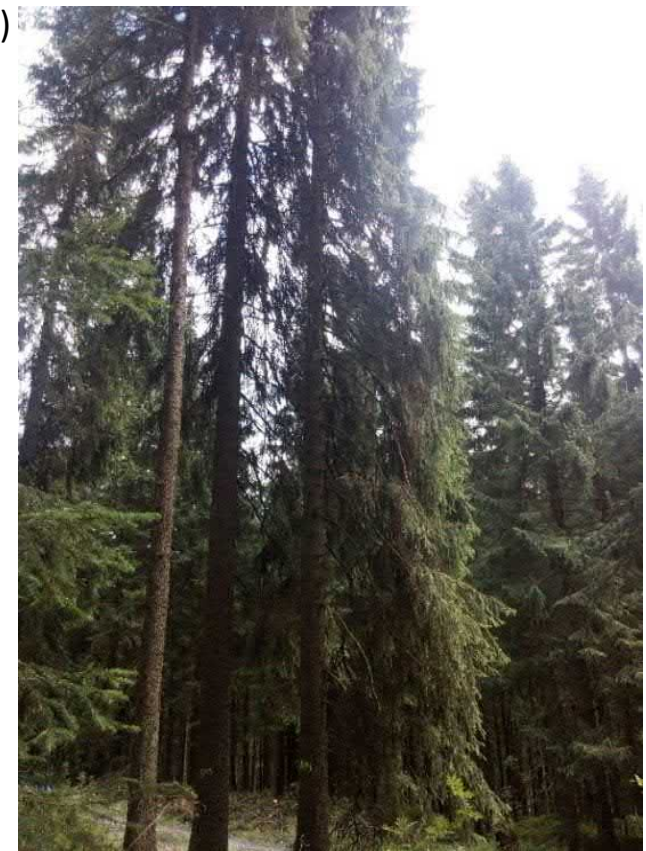

Figure 1: Norway spruce trees representing a) the "lowland" morphotype with damaged crown and subsequent forking, b) mountainous morphotype with downward facing branching and narrow appearance. (O. Caré, 2016) 


\section{The study idea}

In order to develop sound concepts for future forest management strategies knowledge about the genetic diversity and adaptiveness of provenances is needed. Especially with regards to the adaptive potential of future forests, silvicultural management profits from ease of use phenotypic selection criteria with a known association to adaptive genetic variation (Schaberg et al. 2008).

The investigation of Norway spruce populations in higher elevation are motivated by silvicultural management concept for spruce population of the Thuringian Forest service. Beside an increase of mixed forest, the use of plant material of adapted mountainous spruce provenances is planned. Management and utilisation in the past, and the plantation of allochthonous material led to a high proportion of lowland provenance. In mountainous regions, these provenances are susceptible to heavy snow loads and wind. Only few stands are regarded as autochthonous and suitable for seed harvests with the aim of replacing the maladapted stands. One remarkable stand is the so called "Schlossbergfichte" near Oberhof in the Thuringian Forest. The stand is characterised by relative few very old trees and their progeny with the typical mountainous ecotype. But due to its small size, the stand is not able to cover the demand of seeding material. Thus, the characterisation of mountainous ecotypes on a genetic level to aid the selection of suitable seed material is one practical application that motivated the here presented study. Stands of mountainous regions in Thuringia, the Ore Mountains, and the Harz Mountains were included, representing typical conifer forest areas, with a long history of wood exploitation.

Aims of the study are: In Chapter I (p.33) the characterisation of putative planted and autochthonous Norway spruce stands at neutral genetic marker and morphological traits is presented. In Chapter II (p.65), association analyses between SNPs, in potentially adaptive candidate genes, and the crown shape target the genetic basis of high elevation adaptation. These should unveil potential adaptive differences between morphotypes. In Chapter III (p.93), seed samples of half-sib families from a mountainous stand in Thuringia are investigated to characterise genetic effects of gene flow and mating system. Such knowledge is crucial in the assessment of stands for in situ conservation of genetic resources and evaluation of the produced reproductive material through seed harvesting. 


\section{Sample material}

In elevated regions, between $761 \mathrm{~m}$ and $1065 \mathrm{~m}$ a.s.l.,of the Thuringian Forest, the Ore mountains and the Harz Mountains pairs of pure spruce stands were selected. One pair consists of a putatively planted stand originated from allochthones material and an autochthonous stand with characteristics of the mountainous spruce ecotype. Location of the stands can be found in Ch. I Fig. S1 (p.59). These stands grow under similar climatic condition in higher altitudes of the respective regions (Ch. I Tab. 1 ; p.37). In these stands, needle material from 200 adult trees was obtained, representing a continuous sampling of all upper layer trees until the target sample quantity was reached. Where the Northwest German Forest Research Institute (NW-FVA) provided 250 samples of the autochthonous population at Mt. Brocken (Harz mountains). Additionally, the relict stand "Schlossbergfichte", situated near the city of Oberhof in the Thuringian forest was included with 75 individuals. With the oldest trees now up to 285 years old (Wilhelm 1990; Jetschke 2019), these are considered the natural occurring type of spruce in the higher elevations of the Thuringian forest. All sampled trees where visually assessed for their crown architecture (Ch. I 2.2.; p.37). Seed samples for the analysis of the mating system in the high elevation stand in the Thuringian Forest were provided by the Forstliches Forschungs- und Kompetenzzentrum Gotha (FFK Gotha). 


\section{Overview of the project results, discussions, and additional remarks}

\subsection{Neutral genetic and morphological differentiation of Norway spruce stands in the German uplands}

Presented in: Caré O, Müller M, Vornam B, Höltken A, Kahlert K, Krutovsky K, Gailing O, Leinemann L (2018) High Morphological Differentiation in Crown Architecture Contrasts with Low Population Genetic Structure of German Norway Spruce Stands. Forests 9:752.

\section{Introduction}

Spruce species, and conifers in general, have effective long distant geneflow (Mitton and Williams 2006). The usually low neutral genetic differentiation between Norway spruce populations, even from geographic distant regions, is mainly attributed to this factor (Heuertz et al. 2006; Tollefsrud et al. 2009). Further, the translocation of seed and seedling material lead to an artificial mix of genetic variation in central Europe (Jansen et al. 2017). On the other hand, environmental conditions are highly variable throughout the distribution range. Thus, translocation of provenances might introduce maladapted material to a region. Local adaptation is nevertheless the key for the maintenance of stable populations (Savolainen et al. 2013). A clearly visible adaptive kline is the crown morphology, changing from an overall broad shape to a narrow appearance with increaseing altitude or latitude (Schmidt-Vogt 1977; Geburek et al. 2008).

In the selected stands trees were morphological assessed and sampling of needle material for genotyping was conducted. The stand pairs differed in their assumed provenances and stand history. One being a putatively planted stand, possible established with translocated material, and the other a autochtonous and natural regenerated stand. The main objective was to quantify the phenotypic and natural genetic differentiation between these stand types.

Chapter I (Caré et al. 2018) quantifies the neutral genetic and phenotypic differentiation between the investigated stands. Based on the previously reported distribution of genetic and morphological variation in Norway spruce the hypotheses were, that between the stands non to very limited genetic differentiation is found, but genetic diversity is high and retained on the individual and population level. The crown morphology on the other hand, was expected to show high phenotypic differentiation between the planted and natural stands. The divergence between phenotypic and genetic differentiation could then be interpreted as signature of natural selection shaping the variation pattern of morphological traits. 


\section{Materials and Methods}

All trees were visually assessd for their crown architecture by overall crown shape, orientation of primary order branches and secondary branching pattern. The traits were scored on a three level scheme, partitioning the gradual traits in mountainous, intermediate and "lowland" type (Ch.I Tab.2; p.37). The scheme is primarily derived from the characterisation of crown morphology of (Gruber 1989) and further incorporated crown assessment in Norway spruce by various authors (Priehäusser 1958; Schmidt-Vogt 1977; Gruber 1993; Geburek et al. 2008). Additionally, damage to the main stem in the crown and subsequent forking was recorded. The 1325 obtained samples were genotyped at 7 random genomic SSRs (gSSRs) and 4 expressed sequenced tag SSRs (EST-SSRs) (Ch.I Tab.3; p.38).

Additional to the diversity and population structure analyses based on the genetic data, comparable statistical methods were used to examine and quantify both genetic and morphological differences and differentiation of the investigated stands to obtain comparable results. Beyond variance differentiation based approaches for phenotypic $\left(P_{S T}\right)$ and genetic $\left(F_{S T}\right.$, $G^{\prime \prime}{ }_{S T}$ ) data, discriminant analysis of principal components (DAPC) (Jombart et al. 2010) was used to examine between group separation. The use of discriminant analysis (DA) on the principal components (PC) allowing for (auto-)correlated variables in the original data, which can be the case in genetic data, possible by marker linkage, and for phenotypic traits that for example follow the same/similar gradients. To incorporate spatial structure in the multivariate analysis, spatial principal components analysis (sPCA) (Jombart et al. 2008) was used, that expands the variance focused PCA by spatial autocorrelation.

Results and discussion

Clear indication of the genetic basis of crown shapes and signatures of natural selection can be derived by the much higher phenotypic differentiation $\left(P_{S T}\right)$ between stands of assumed different provenances growing in the same environment compared to their overall low neutral genetic differentiation $\left(F_{S T}, G^{\prime \prime}{ }_{S T}\right)$. This result supports the heritability of crown architecture in Norway spruce, previously assumed in literature (e.g. Sylvén 1909; Kiellander 1962; Schmidt-Vogt1977).

The morphological crown characteristics between putative planted stands and the putative native (autochthonous) mountainous stands differ over all regions examined. Overall, the mountainous stands showed an overall narrower crown shape, a tendency of the primary branches facing downward and a plate to brush like secondary branching pattern (e.g. SchmidtVogt 1977; Gruber 1989). Contrasting, the putative planted stands showed a broad crown shape, strait to upwards facing branches and a comb-brush to comb like secondary branching. 
A broad crown form and a comb-like branching are considered traits of the "lowland" provenance. These lowland provenances in the Harz mountains and the Thuringian forest further have extensive crown damages, resulting in subsequent forking, also a sign of maladaptation to the site conditions (Ch. I Fig.1; p.42 \& Ch.I Supp. Tab. S2; p.57). Phenotypic differentiation $\left(P_{S T}\right)$ for the morphological traits was high $(\geq 0.95)$, even when low additive variance to narrow sense heritability ratios were considered (Ch.I Supp. Fig. S3; p.60). Thus, the estimate is very robust, even in the absence of information on the amount of genetic control (for details on the calculation of $P_{S T}$ see Ch.I 2.5; p.39 and Brommer 2011; Leinonen et al. 2013). DAPC confirmed the high phenotypic differentiation between the assumed provenances (Ch.I Fig. 2; p.43).

In accordance to other studies (Chevarria 2005; Scotti et al. 2006; Tollefsrud et al. 2009; Unger et al. 2011) low between population differentiation accompanied by high within population diversity was found. No divergences in terms of diversity or allelic richness between the putative planted lowland provenance and natural regenerated stands of high elevation provenance were detected. Supporting (Müller-Starck 1995) and opposing (Gömöry 1992; Maghuly et al. 2006; Radu et al. 2014) results for this observation were previously reported.

The genetic differentiation between the presumed provenances was low. Only very slight indication of separation of autochthones population can be found in the the population structure analysis considering higher cluster numbers than the best supported $K=2$ (Ch.I Supp. Fig. S10; p.65). Although, genetic separation of different ecotypes or between autochthones and planted stands in mountainous environments was previously reported (Jeandroz et al. 2004; Máchová et al. 2018).

Despite the overall low neutral genetic differentiation, weak but clear differentiation of the populations in the Harz region was observed. This result is likely attributed to a more recent recolonization history (Terhürne-Berson 2005), resulting in a still visible founder effect. In the past seed material was also obtained from local populations (Jansen et al. 2017). Thus, plantation within the region could be conducted with local material retaining the regional genetic structure.

Further, an indication of the relict characteristics of the population "Schlossbergfichte", previously deduced by morphology and age (Wilhelm 1990; Jetschke 2019), was found to be reflected in the genetic variation. This is the only example of a high elevation type stand genetically differentiated to the "lowland" types stands. Suggesting low introgressive geneflow in the "Schlossbergfichte", but high rates of gene flow between the stand pairs, especially within region of the Ore mountains . 


\subsection{Remarks on Caré et al. 2018ף}

Stand classification in mountainous ecotypes and putative planted stands was performed according to the stand- and estimated age structure, occurrence of narrow phenotypes and the assessment of local foresters (See Ch.I 4.1.; p.46). Written documentations of the stands' origin are unfortunately not available. In the study, the populations in the Thuringian mountains can be regarded as the prime example of these stand classifications. Either clear uniform age and stand structure with clearly visible row design in the putative planted stand or multi-layered structure with no indication of former planting activity in the high elevation stand. Whereas, in Saxony the classification is less clear. Both stands might have admixtures of the other stand type in minor proportion. Such a mixed stand structure is exemplary illustrated by the distribution of crown shapes in one stand, classified as autochthonous mountainous type, in the Ore mountains, Saxony (Fig.2). In the centre of the sampling area a group of broad crowned trees is identifiable. PSuch pattern might be caused by natural regeneration with a high influence of immigrant pollen or due to a replantation of a small clearing. Therefore, the assessment of the crown shape in the complete stand is crucial for evaluating its status as mountainous ecotype. In case the stand is used for harvesting seeds, such assessment could be included in the thinning/ harvest operation to remove undesired tree types.

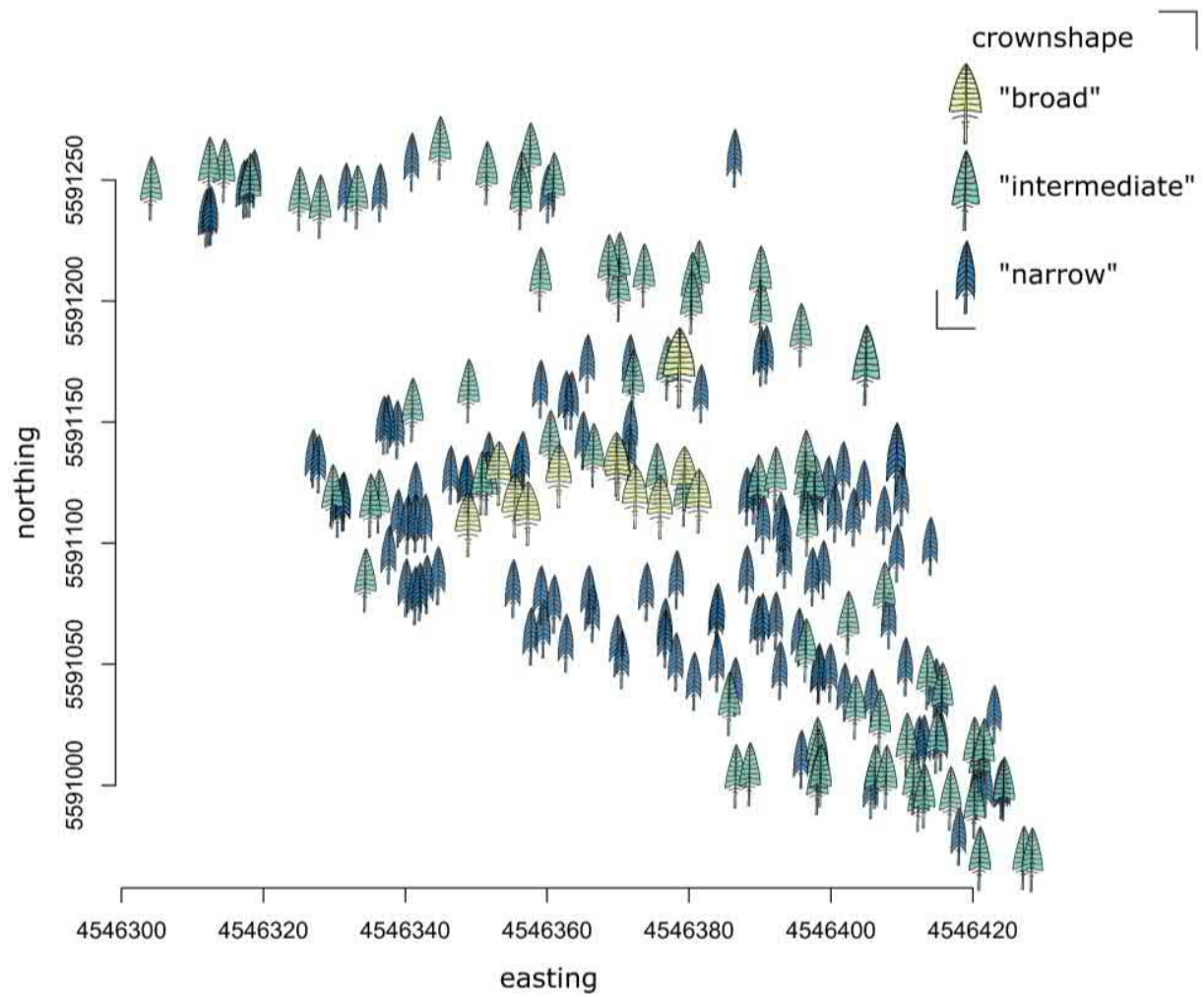

Figure 2: Spatial distribution of crown shape in the putative autochthonous stand in the Ore mountains Saxony. Axis represent easting/northing in DHDN / 3-degree Gauss-Kruger zone 3. 
Nonetheless, the morphological characterisation of the crown captures both, the genetic and environmental influence on the phenotype. For Norway spruce especially stand density and layering has an influence on the height to diameter ratio, proportion of the living crown, branch length and crown width (Deleuze et al. 1996; Grassi and Giannini 2005). As already mentioned, extreme site condition can alter the crown shape even for high elevation provenances, like the Mt. Broken population in the Harz mountains (Ch.I $4.2 ;$ p.47).

Even though various subtypes and combination of trait expression were described (Schröter 1934; Priehäusser 1958), here a three-class system for the continuous traits was used. It follows former used classification approaches (Gruber 1989; Geburek et al. 2008), without the transition types. Trees where always assigned to the intermediate type, if no clear expression of the mountainous or lowland type was visible. This led to a high proportion of intermediate type trees in the most stands investigated, possible underestimating the proportion of either mountainous or lowland type trees. However, crown morphology has a complex expression, that may also be environmentally influenced. The use of a clear and easy scoring scheme and assignment of ambiguous individuals to the intermediate class certainly reduced scoring errors.

The neutral genetic differentiation between the stands of putative different provenances within each region was found to be small, and no genetic differentiation was observable. An exception is the differentiation between the population "Schlossbergfichte" and the planted stands indicating the relic character of this provenance (Ch. I $4.3 ;$ p.47). Nonetheless these difference where too small to assign individuals to ecotypic groups using SSR markers. This result is supported by the absence of clear differentiation between ecotypes in a comparable study (Bínová et al. 2020). The authors accordingly conclude, that the marker set is not capturing the selective process of ecotypic differentiation and population structure. Further, the authors also suggest that, the genetic structure is influenced by the high amounts of geneflow assumed in Norway spruce. Contrasting results were reported in a study on Czech Norway spruce stands using mainly, potentially adaptive EST-SSRs, where a clearer separation between population and ecotypes was found (Máchová et al. 2018). The EST-SSRs used in the presented study, did not show differentiation between ecotypes. With very few individuals investigated $(\mathrm{N}=5)$ genetic differences between spruce trees in Serbia (Galović et al. 2015) can more likely be related to the high individual diversity, than population differentiation. 
Further, distinguishable pattern between regions at RAPD markers and between autochthonous and planted stand when combined with mitochondrial markers was found in stands at the Vogues mountains (Jeandroz et al. 2004). The authors stated that the use of planting material of a distant gene pool, likely material from Germany, is the reason of the differentiation found.

Based on the found regional differentiation of the Harz mountains to the other study regions and absence of differentiation in the stand pair, it has been concluded, that the planted population originated from local material (Ch.I 4.3. ; p.48). The population at Mt. Broken can be considered autochthones with relatively high confidence by the forest history of Mt. Broken (cf. Greger 1992). Due to their genetic similarities, both stands have likely undergone similar demographic processes, resulting in the conclusion of identical regional origin. This conclusion is also supported by the estimated complete bidirectional geneflow in the relative migration network (Ch.I Supp. Fig. S8; p.62).

Jansen et al. (2017) described in detail historical seed trade in Germany. Seed material was also heavily imported into the Harz region comprised of a broad variety of origins. For example in the local region of "Westerhof", stand establishment was conducted mainly with imported material. As also stated, the Harz region was production center for huge amounts of seeding material. This material was used within the region and traded, mainly over Darmstadt, throughout Germany and beyond. Thus, planted stand in the Harz region could have originated either of local or imported material. Evidence from the investigated planted stand point to the local origin. 


\subsection{Search for signs of genetic adaptation between morphological differentiated trees}

Presented in: Caré O, Gailing O, Müller M, Krutovsky K V., Leinemann L (2020) Crown morphology in Norway spruce (Picea abies [KARST.] L.) as adaptation to mountainous environments is associated with single nucleotide polymorphisms (SNPs) in genes regulating seasonal growth rhythm. Tree Genetic and Genomes 16:4.

\section{Introduction}

Norway spruce provenances from different latitudes or altitudes are known to differ in their cold hardiness, growth and flowering rhythm and yield (Kalela 1937; Qamaruddin et al. 1993; Modrzyński and Eriksson 2002; Chmura 2006; Gömöry et al. 2010; Liesebach et al. 2010; Kathke and Bruelheide 2011). Within the last decade also candidate genes involved in the control of these traits have been identified (Gyllenstrand et al. 2012; Scalfi et al. 2014; Chen et al. 2016; Di Pierro et al. 2016, 2017). Whereas, surprisingly little is reported about crown morphology. Very few studies exist that covers both assessment of the crown morphology and genetic markers (Galović et al. 2015; Máchová et al. 2018; Bínová et al. 2020), but investigation in putative adaptive SNPs related to morphology are missing. Chapter II (Caré et al. 2020a) presents association analysis between the morphological crown shape of Norway spruce trees growing at similar elevation and putative adaptive SNP markers in previously identified candidate gene. The aim is to unveil the genetic basis of high elevation adaptation and confirm the genetic adaptation to the mountainous environment of the high elevation ecotype.

\section{Materials and Methods}

To analyse putative adaptive variation associated with the crown morphology, a subset of 765 individuals from the 1325 sampled trees was genotyped at 44 single nucleotide polymorphisms (SNPs) in candidate genes. The selected individuals included 115 trees for each stand and all 75 sampled trees from the relict stand "Schlossbergfichte", respectively. SNPs in candidate genes involved in processes related to or associated with phenological, environmental or local adaptation in Norway spruce were selected for genotyping (Heuertz et al. 2006; Gyllenstrand et al. 2012; Källman et al. 2014; Chen et al. 2016; Heer et al. 2016; Ganthaler et al. 2017b). Association between the SNP genotypes and the crown form was assessed by generalised linear models implemented in the software TASSEL 5.0 (Bradbury et al. 2007) and SNPassoc 1.9-2 (Gonzalez et al. 2007), accounting for the neutral population structure as covariate, obtained from the SSR data (Caré et al. 2018). A differentiation based approach (Gregorius and Roberds 1986; Gillet 2013) and $F_{S T}$-outlier detection (Antao et al. 2008) was further used to detect SNPs with significant diverging allele frequency patterns between groups of the same crown shape, which also points to directional selection (Gillet et al. 2016). Multiple testing was accounted for by adjusting the $p$-value distribution for the false discovery rate (FDR) (Storey 2002; Storey and Tibshirani 2003). 
Results and discussion

Highly significant association between genetic markers and the individual crown shape was found for six SNPs in three candidate genes after adjusting for false discovery rate (FDR), based on a $q$-value $\leq 0.05$. Trees with different crown shape from the Thuringian Forest were significantly differentiated at two SNPs in the APETALA 2-like 3 (AP2L3) gene. Two SNPs in a GIGANTEA (GI 6) gene where highly significant associated with groups of different crown shape. Significant association was also found for one SNP in a mitochondrial transcription termination factor related (mTERF) gene. For both candidate genes this observation was made for the pooled sample over all regions and the Thuringian samples.

Additionally, five SNPs had significant association or differentiation at $p \leq 0.05$ for the crown shape groups, detected by several methods but failed to reach significant threshold when FDR correction was applied. These five SNPS (BIF2L2-423, BIF2L2-747, NODE-60-length-1132-cov, PabiesPRR1-1992, and PabiesPRR1-3828) located in three genes encoding D6-protein kinase-like 2 (D6PKL2), one gene with unknown function (UF), and pseudo-response regulator 1 (PRR1) or synonymous timing of CAB extension 1 (TOC1), respectively.

In two core circadian clock genes, SNPs where identified to be highly (GI6-1089, GI61207) and nominal (PabiesPRR1-1992, PabiesPRR1-3828) significant associated with the crown shape. The overall observed allele frequency pattern of the GI6-SNPs, with the major allele more frequent in the narrow crowned individuals, match with altitudinal and latitudinal patterns in Norway spruce. The major allele increases towards higher altitude or latitude (Gyllenstrand et al. 2012; Chen et al. 2016). Further, GIGANTEA genes were previously identified as candidate genes for local adaptation in several conifers (Gyllenstrand et al. 2012; Holliday et al. 2013; Chen et al. 2014; Alakärppä et al. 2018). As with SNPs in GI6, the genotypic pattern of the PRR1 SNPs, observed in the group of narrow compared to broad crown types, showed similarities to patterns observed along climate gradients in Pinus sylvestirs (Kujala and Savolainen 2012). Thus, the presented results support that, circadian clock genes have a crucial role in local adaptation of Norway spruce. 
Among seed plants APETALA2 like genes (AP2L1, AP2L2, AP2L3) are functionaly conserved (Shigyo and Ito 2004; Shigyo et al. 2006; Nilsson et al. 2007). In Picea spp., AP2-like genes show variation patterns related to temperature, stress, and adaptation over broad geographic regions (Namroud et al. 2008; Prunier et al. 2011; Chen et al. 2016). Only as a regional specific effect in the analyses SNPS within AP2L3 (AP2L3-2312, AP2L3-2842, AP2L3-2907) high significant differentiation between groups in the Thuringian region was found, but no significant association.

Significant association with crown shape was further found for one SNP (MA_39589g0010-566) in the mTERF gene. Despite spare knowledge about the functional role in plants, an adaptive importance to environmental stress response was suggested (Kleine 2012; Robles et al. 2012; Quesada 2016). The observed similarity of allele frequencies pattern between sites and regions of this SNP, with a low minor allele frequency, supports the assumption of adaptive importance of the gene and transferability to other regions.

Association to the crown shape was also identified in one SNP (NODE-60-length1132-cov) in a gene of unknown function but linked to the phytoalexin synthesis in P. abies. Thus, this gene has a putative role in the resistance to fungal pathogens (Ganthaler et al. 2017a, b). In the regions Harz mountains and Thuringian forest, the genotype associated with higher content of phytoalexin was more frequent in the group of broad and intermediate trees.

Two nominal significant associated SNPs (BIF2L2-423, BIF2L2-747) were found in a gene putative coding a D6PKL protein. The gene is presumed to be involved in the plants' reactions to low temperatures (Sun et al. 2009) and the auxin transport, thus influencing development and growth (Willige et al. 2013; Miao et al. 2018; Zhou and Luo 2018). Hence, this gene is a potential candidate for plant structure. 


\subsection{Remarks on Caré et al. 2020a}

Candidate genes regulating phenological traits (Gyllenstrand et al. 2012; Scalfi et al. 2014; Chen et al. 2016; Di Pierro et al. 2016, 2017), wood formation and wood quality traits (Jokipii-Lukkari et al. 2018; Baison et al. 2019) have been identified in Norway spruce. In contrast, association of candidate gene to the crown architecture had not yet been investigated. The study demonstrated significant association of SNPs to the crown shape, which in nearly all cases can be considered to reflect co-adaptive patterns. Meaning the SNP variation, as well as the crown trait variation, following the same gradient without direct dependencies between both. Here, both the crown-shape and the found phenological related SNPs are subjected and influenced by similar environmental gradients related to an altitudonal shift. Thus, correlation occurs between SNPs, crown shape and provenance and this is reflected in the significant association between SNPs and the crown shape. Nevertheless, these results demonstrated for the first-time differences in the genetic adaptation between morphotypes. Exclusively, one candidate gene (D6PKL) identified could have a putative role in plant structural development by its role in the auxin transport. Accordingly, studies to identify genes responsible for the morphological appearance in Norway spruce are needed to understand the formation of different crown types.

The trait expression of the crown shape is at most characterizable at an ordinal scale, limiting the spectrum of analytic methods compared to nominal or ratio scaled traits. Additionally, the crown characteristic is only fully expressed in the adult phase of the tree (Schmidt-Vogt 1977), making growth under control condition difficult and excluded greenhouse experiments. Field conditions can also influence this trait especially by spacing and competition effects (Deleuze et al. 1996; Grassi and Giannini 2005), making it a difficult trait to study. Hence, the used categorical scale with three levels for the crown shape in the study compensate for uncertainties by using the intermediate type also in cases where unclear trait expression was observed. Possible this lowered the statistical power of the analysis for the regions especially the Harz Mountains. In this region a higher proportion of trees in the autochthonous stand were scored as intermediate, due to the strongly damaged appearance by the exceptional extreme site conditions (see Ch.I, 4.2.; p.47). It could be speculated, that under slightly more moderate environmental conditions, these trees would nearly all be identifiable as the narrow crown type. Thus, the number of individuals in the group would increase and results might show more significant SNPs. Conclusively, the used phenotypic characterisation is more prone to produce false negative than false positive results in genetic association analysis. 
Generalised linear regression was used for identification of a present association. To be significantly correlated, the frequency of a genetic variant must follow a linear trend, from broad over intermediate to narrow trees (for example: Ch.Il, Fig. 3; p.72). Differentiation based approaches, however, only require clear distinction between groups independent of a ranking. The significant differentiation at the AP2L3 SNPs in Thuringia, under absence of significant association, is based on the difference between the intermediate and both other groups (Ch.II, Fig.S8 a-c; p.88). The result can be discussed with regards to the distribution of phenotypes among the stands in the region. Intermediate types occur almost exclusively in the autochthonous stand in Thuringia. The relict stand "Schlossbergfichte" and the planted stand are comprised of narrow and nearly entirely broad trees, respectively (Ch.I, Fig.1; p.42). Hence, the differentiation can also be seen as a differentiation of crown shape groups within the autochthones stands. APETALA2 are amongst other involved in the regulation of flowering time (Jofuku et al. 1994; Nilsson et al. 2007), possible indicating differences in the genetic control of flowering time within the stands morphologically differing trees. Hence, flowering time, and potentially also bud break, should be observed in autochthones stand and correlated to genotypes and crown shape to investigate this hypothesis further.

Differences in the defence strength against pathogens might be suggested by the differences observed between the phenotypic groups at a SNP related to phytoalexin synthesis. However, functional role of the gene is so far unknown. In the group with narrow crown shape in the Harz mountains and the Thuringian Forest the more frequent found genetic variant is related to a lower needle content of trans-resveratrol and transpiceatannol (Ganthaler et al. 2017b). Synthesis of trans-resveratrol is induced in response to phytopathogenic microorganisms in several plant families (Jeandet et al. 2010; Ahuja et al. 2012; Ribera and Zuñiga 2012) and higher needle content in spruce correlates with lower susceptibility in the early infection phase with Chrysomyxa rhododendri (Ganthaler et al. 2017a). Difference in the investment into the defence system in the adaptation to different environments could be explained by occurrence and severity of pathogens. A lower impact, measured by growth reduction, is reported for trees infected with Heterobasidion parviporum growing at high altitude and was related to suboptimal conditions for the pathogen (Gori et al. 2013). With increasing altitude herbivore pressure is lowered, but especially physical resistance of leaves increases, possible due to adaptation to abiotic stress (Rasmann et al. 2014). However, diverse effects and complex interaction in plant host systems along altitude gradients exist (Hodkinson 2005) with no clear "winner" at higher altitudes. 
The two phytoalexins mentioned represent only a very small part out of the bandwidth of chemical components involved in plant defence (Bennett and Wallsgrove 1994; Jeandet et al. 2010; Dar et al. 2015). Thus, a conclusion on the defence capabilities in different crown shape groups by the observed group differentiation would be exaggerated. It is expected, that community composition and species distribution range of pathogen change with changing climatic conditions and their development conditions might improve (Rasmann et al. 2014). In the selection of provenances the degree of resistance to pathogen needs consideration. Therefore, further studies on the defence system and genetic variation related to plant defence in different provenances, not exclusively from different altitudes, are highly recommended. 


\subsection{Mating system analysis in a native Norway spruce stand estimated high levels of immigrant geneflow}

Presented in: Caré O, Gailing O, Müller M, Krutovsky K V, Leinemann L (2020) Mating System in a Native Norway Spruce (Picea abies [L.] KARST.) Stand-Relatedness and Effective Pollen Population Size Show an Association with the Germination Percentage of Single Tree Progenies. Diversity 12:266.

Introduction

Norway spruce stands in Germany, characterised as high elevation type, are frequently used as seed source for forest reproductive material. These stands are surrounded by putative planted populations of maladapted provenances (Paul et al. 2010). High pollen mediated gene flow is commonly found in wind-pollinated conifers and accounts to a large extend of the low interpopulation genetic differentiation (Xie and Knowles 1994; Burczyk et al. 2004; Mitton and Williams 2006; Tollefsrud et al. 2008; Williams 2010; Di Pierro et al. 2017). Thus, possible geneflow between stands of different origin could alter adaptive genetic structure between the parent population and the progeny. To assess the mating system and the level of immigrant gene flow, seed sample of a native Norway spruce stand, representing 21 half-sib families, were investigated. Further, germination of the seed samples was observed to assess a possible impact of genetics on fitness in an early ontogenetic stage.

\section{Materials and Methods}

Cones samples from 21 trees in a native Norway spruce stand in the Thuringian Forest were collected in March 2017. The samples were kept and studied separately for each mother tree to retain the half-sib structure. Trees selected for the sampling can be spatially classified as groups in the northern, the central and the south-eastern part of the stand (Ch. III Fig.1; p.112). The 200 adult trees in the stand were previously sampled, scored and analysed for phenotypic, neutral genetic (Caré et al. 2018) and in part for putative adaptive genetic variation (Caré et al. 2020a). Germination of 84 seeds per family each was observed for ten days on moist tissue paper in petri dishes under ambient conditions. Germination progress was rated daily. For the genetic study 20 randomly chosen seeds per family were prepared for DNA extraction, either when the root tip has emerged and elongated or after the 10-day observation period. In 5 families less than 20 out of the 84 seeds were usable for DNA extraction due to high percentage of hollow seed. The same SSRs used in the characterisation of the adult trees (Ch.I Tab.3; p.38), excluding EST-SSR PaGB8, were used to genotype the endosperm and the embryo of each seed. With the genetic information of the haploid maternal contribution and the diploid embryo, also the haploid pollen contribution to the embryo could then be determined. 
Parentage assignment was performed by matching haploid pollen genotypes to the genotype of the adult trees and by a likelihood approach implemented in the software CERVUS (Kalinowski et al. 2007). Seeds without assigned parental trees within the stand were considered to descend from immigrant pollen from the surrounding stands. In addition to diversity and fixation indices, effective pollen population size and relatedness among single half-sib families was calculated. To account for uneven sample size, rarefaction resampling was used to estimate both metrics. Afterwards, linear regressions were used to assess correlation between the germination percentage and genetic variation.

\section{Results and Discussion}

Between the half-sib families seed germination percentage varied considerably, from $3,6 \%$ to $61,9 \%$. Germination percentage for the complete seed lot was estimated with $38,5 \%$ (Ch. III Tab.1; p.98). Factor influencing germination percentage are pollination success and environmental condition. Fluctuation also occur between trees, location, and year (Andersson 1965; Skröppa 1996). The material was not commercially processed, and hollow seeds remained in the sample. Thus, the overall high proportion of empty seeds is the main cause of the low germination percentage. In conifers, hollow seeds are mainly formed by selfing and inbreeding, inducing postzygotic embryo abortion by expression of deleterious recessive alleles (Mergen et al. 1965; Fowler and Park 1983; Woods and Heaman 1989; Lynch 1991; Kuittinen and Savolainen 1992; Berrill and Libby 2016). One possible factor for an increased selfing rate might have been a restricted pollen production, as the sample represents a partial mast year.

For genetic variation between half-sib families was also found in a) the observed $\left(H_{o}\right)$ and expected $\left(H_{e}\right)$ heterozygosity, ranging from 0.517 to 0.713 and from 0.500 to 0.640 , respectively; b) rarefied effective pollen population size $\left(N_{e}(P ; r): 1.1-3.7\right)$; and c) rarefied relatedness within half sib families $\left(r_{(r)}: 0.11-0.33\right)$ (Ch.III Tab.1; p.98). Highly significant linear associations between the germination percent and $r_{(r)}(p=0.005)$, with a negative trend, and $N_{e(P ; r)}(p=0.003)$, with a positive trend, was found (Ch. III Fig.2; p.103). Whereas, no significant relationship of the germination percentage with $H_{0}$ was found, despite a visible positive trend. Different levels of inbreeding in the half-sib families could be a possible explanation for the found variation in genetic indices. Nevertheless, variation in inbreeding levels could not be confirmed statistically. A further explanation could be the variation in the diversity of the pollen contribution in each family, resulting in the variation of genetic diversity and genetic similarity. Lowered diversity and increased similarity in turn result in increased relatedness and decrease effective population size estimates. 
The influence by the pollen is particularly reflected in the estimate of the effective pollen population size, as it was calculated from the haploid pollen contribution. The association to the germination percentage is further plausible, as fitness correlates with genetic diversity in forest trees (Müller-Starck et al. 2005) and study results previously showed correlation between poorer seed performance and restricted population size in other conifers (del Castillo et al. 2011; Wojacki et al. 2019).

High proportion of immigrant pollen was found contributing to the pooled progeny. Depending on the method and confidence threshold used minimum of $70.2 \%$ and up to 91.5\% of analysed seeds were estimated to have descended from pollen of trees outside the sampling area. Pollen immigration, even over large distances, was previously confirmed in Norway spruce (Xie and Knowles 1994; Burczyk et al. 2004). While neutral genetic differentiation between German high elevation native and planted stand was showed to be low (Caré et al. 2018), adaptive genetic variation was associated with morphotypes (Caré et al. 2020a). As the studied stand's surrounding is characterised by putatively planted Norway spruce stands, alteration of the genetic composition of the progeny, particularly in terms of adaptive genetic variation, is likely. Further studies with markers reflecting adaptational processes are hence needed, to further quantify impacts of immigrant pollen and the evaluation of the stand as seed source.

From assigned parent pairs within the stand, a distant depending mating success was found with mating events most frequently occur between trees in a distance between of 0 to 20 meters (Ch.III Fig.3; p.105). Furthest observed pollinations occurred between trees around 170meter apart. This distance dependent pollen dispersal pattern is in agreement with other mating system analyses in Norway spruce stands (Burczyk et al. 2004; Shimono et al. 2011) and results of pollen cloud density (Wright 1952). While only representing the mating in the area with genotyped trees and accounting for approx. $10-30 \%$ of seeds investigated, a different pollen distribution could be expected. Considering all pollen, the distribution could likely show much longer pollination distances.

The demonstrated high influence of pollen from outside the sampled area, contributing to the tested progeny, was considered as a potential problematic influence on the genetic composition and adaptiveness of the progeny. However, to quantify the effect on the adaptiveness of the progeny, further analysis based on adaptive genetic markers (SNPs) are needed. Nevertheless, a spatial influence on the percentage of immigrant pollen within single half-sib families was determined. Seed trees growing in the central part of the stand had an overall lower proportion of $40-60 \%$ of seeds with a parental contribution from neighbouring stands. On the other hand, progenies from trees growing at the edge of the stand had up to $90 \%$ immigrant pollen. 
Thus, the progeny of central trees is expected to reflect the genetic composition of the parental stand more than those of edge trees. In a seed harvest aiming for maintaining the genetic composition of the parental stand, seed should not be collected in direct proximity of neighbouring stands, but in the central area of the stand. While it needs to be stressed, that as many trees as possible should be sampled to avoid the artificial introduction of drift or bottleneck effect to maintain high genetic diversity.

\subsection{Remarks on Caré et al. $2020 \mathrm{~b}$}

As summarised in the study, the impact of immigrant pollen on the genetic composition of progeny and their performance can have various direction. Long-distance geneflow can counteract genetic drift, inbreeding and distribute adaptive relevant genetic variants among population. It may also negatively influence local adaptation by the induced change in allele frequency or breakup of gene complexes in adaptive genes (Krutovsky et al. 2012).

The occurrence of introgression from planted into autochthones stands in mountainous environments has previously been shown (Jeandroz et al. 2004). It may aid in the adaptational process of high elevation provenances under rapid changing climatic conditions (Guisan and Theurillat 2001), but based on the assessment of adaptive genetic variation in planted and autochthones populations (Caré et al. 2020a) a negative influence on the high elevation adaptation is however likely to occur by extended pollen immigration.

Regarding the pronounced number of hollow seeds, the possibility of outbreeding depression by mating of distant gene pools in conifers causing breakdown of adaptive gene complexes was mentioned. Few studies exist, that proposed increased hollow seed formation (Kärkkäinen et al. 1999) or a long term decrease in growth performance, similar to inbreeding depression, (Goto et al. 2011) by outbreeding depression in conifers. While a study investigating the effect of mating distance in Norway spruce on chemical defends and infection with galling aphides, suggested inbreeding depression acting more on the community/ population level rather than having delirious effects on the individual. Moreover, increased mating distance between parental trees was positive correlated with needle content of candidate defensive compounds and fewer galls, at least at one study site (Axelsson and Senior 2018). Thus, this study presented results for the positive effect of longdistant geneflow. While occurrence of outbreeding depression could not be statistically confirmed in the data, it could possible occur in Norway spruce. Hence, controlled crosses within and between provenances are of interest to examine inbreeding and outbreeding effects of close or distant gene pools. Where, inclusion of markers reflecting local adaptation is needed to assess the impact on the genetic side. 
While, previously fine scale genetic structure in high elevation population was reported (Unger et al. 2011; Mosca et al. 2018), neither spatial relationship of relatedness in the autochthones Thuringian stand (Caré et al. 2020b) nor in genetic distance in any of the investigated stands (Caré et al. 2018) could be detected. Unpublished research on the ancestry and kinship of differently structured and managed Norway spruce stands suggest that overlapping of generation masked family structure in natural regenerated stands over generations, making them undetectable without kinship reconstruction (Eusemann, personal communication, Feb. 2020). Thus, further analysis of the genetic data from the autochthones stands could be conducted and discussed with regards to this aspect.

Seeding material is expected to reflect the genetic composition of the harvested stand. Thus, forest reproductive material with high immigrant pollen contribution is undesired, also in the light of conservation of genetic resources. With the spatial dependency of the amount of immigrant pollen contribution to single tree progenies, seed harvest in large stands could be conducted in core area of the stand. However, the harvest area needs to represent enough trees to both respect the law and ensure the maintenance of genetic diversity. Under consideration of the complete genetic analysis conducted, the establishment of seed orchards with phenotypically and genetically assessed and tested individual could be used to produce seed material with desired properties. Like in seed stands, measures to minimizing immigrant pollen would be needed. Also, the growing area for a high elevation provenance seed orchard must be characterised by mountainous environment condition to avoid possible undesired epigenetic effects on the progeny. For examples see Johnsen et al. $(1996,2005)$. Measures to reduce immigrant pollen in a seed orchard could include a buffer area where desired tree genotypes grow but are not considered for seed production. In this buffer area, pollen from chosen genotypes is produced and contributes to the progeny of the actual orchard. This measure could not only be adopted for new but also in exiting seed orchards. Both for implementing recommendations on seed harvesting and define the width and spatial positioning of buffer areas, further studies are needed. Aim would be to estimate the expected local pollen contribution depending on stand characteristics. Multiannual data from divers stands of pollen contribution and influence of spatial position of the tree within the stand, topography, prevailing wind direction and surrounding stands on the percentage of immigrant pollen in single tree progenies would be needed. Desirable outcome for seed stands would be the estimation of suitable harvest areas, exemplary illustrated in Fig. 3. The figure shows an interpolation of the estimates of pollen contribution based on the genetic data. Ideal would be to generate such estimates, precise 
enough for practical application, without or only very limited genetic analyses. Possibly adapting dispersal and demographic populations models (Jongejans et al. 2008), or methods for modelling pollen dispersal on landscape level (Di-Giovanni et al. 1989; Fyfe 2006; Schueler and Schlünzen 2006; Bunting et al. 2008) often used vegetation reconstruction in palaeobotany.

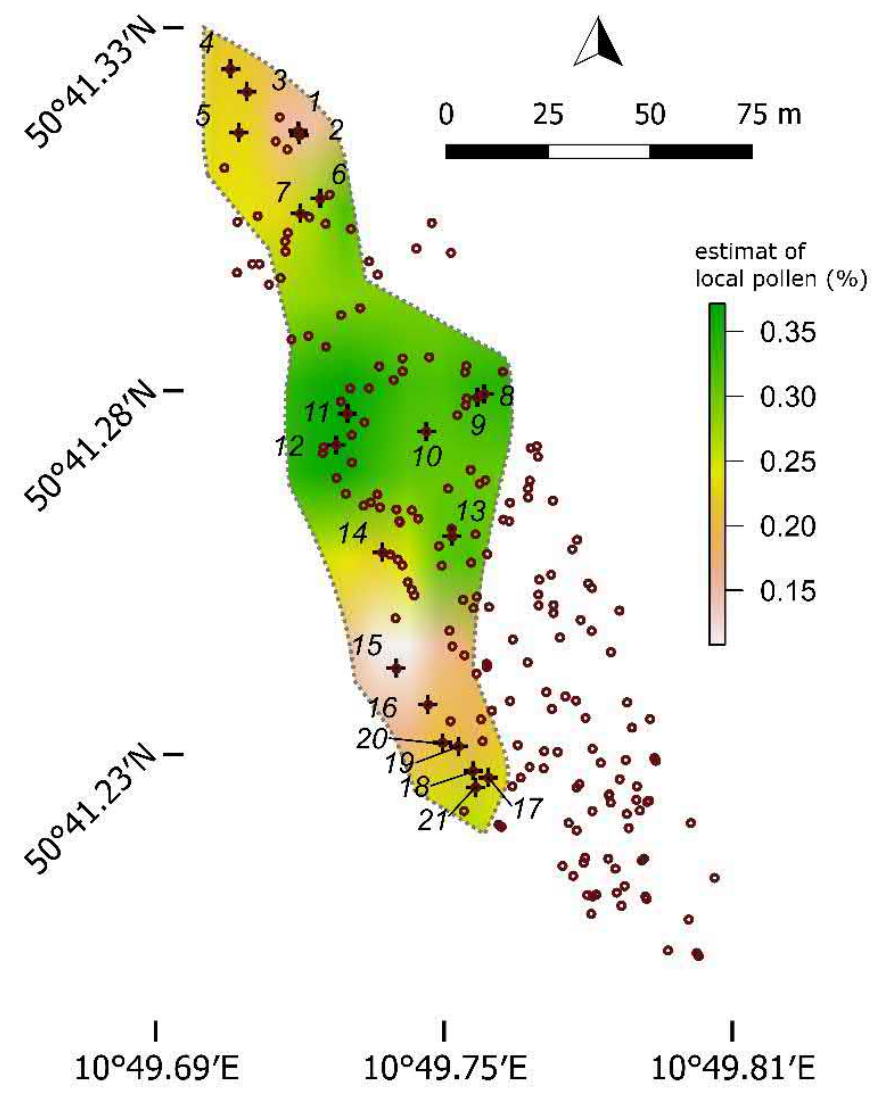

Figure 3: Preliminary and exemplary illustration of the estimated proportion of local pollen contribution to the progeny. Circles represent the genotyped adult trees, crosses with corresponding numbering the seed trees investigated. The estimated percentage of local pollen to the progeny is indicated as background colouring and given for the area demarcated by the dotted line. Corresponding scale displayed on the right-hand side. Estimate is based on an inverse distance spatial interpolation of the percentage of seeds with locally assigned pollen donor by a comparison of genotypes of the adult trees and the haploid pollen contribution. 


\subsection{Conclusion and outlook}

German high elevation Norway spruce populations showed low neutral genetic differentiation, even between autochthonous and planted populations. While phenotypic assessment of the crown morphology revealed high variation between the autochthones and putative planted stand independent of the region investigated. Expression of crown traits showed to be relative stable even under extreme site conditions. This suggests that, the crown shape is under strong genetic control. Common garden experiments should be conducted in order to assess heritability of overall crown shape, branching pattern and branch angle. (Ch.I, Caré et al. 2018)

Narrow crowned Norway spruce provenances are also interesting for breeding purposes and hybrid breeding between common and narrow spruce forms had also previously been suggested (Pârnuţă 2003). Recent studies showed the influence of the provenance on the slenderness of the tree (Apostol and Budeanu 2019) and further present, that the narrow crowned form Picea abies f. pendula in average has more favourable stand stability traits (slenderness, wood density, diameter and finesse of branches) (Apostol and Budeanu 2019; Budeanu et al. 2019). Further, it is reported narrow crowned provenance have a higher yield per area compared to broader crowned provenance (Pulkkinen and Pöykkö 1990; Gerendiain et al. 2008). Hence, aspects of tree improvement could be incorporated in the suggested common garden experiments.

Crown shape could be effectively used in the assessment of the adaptiveness of Norway spruce population to mountainous site conditions. Highly significant association between SNPs in candidate genes related to local adaptation and the crown shape, showed adaptiveness of narrow crowned trees. Further, it suggests that directional selection is responsible for the found differences between crown morphology groups. Genes of the circadian clock, namely GIGANTEA 6 and PRR1, where identified and the coincident allele distribution between the presented study and previous research at latitude clines demonstrate the important role of these genes in local adaptation with high confidence (Caré et al. 2020a). With the high number of investigated individuals ( $N=765$ ), genetic association in high elevation population could be studied with high accuracy also taking the categorical phenotyping into consideration. Nevertheless, only a carefully selected but small proportion of SNPs $(N=44)$ was investigated. With the presented results further extension of the marker set could detect genes involved in environmental adaptation and expression of the phenotype. (Ch. II, Caré et al. 2020a) 
Samples of single tree progenies collected in a native Norway spruce stand in the Thuringian Forest showed association between the germination percentage, the relatedness $\left(r_{(r)}\right)$ and effective pollen population size $\left(N_{e}\left(p_{;} r\right)\right)$. Lowered number of pollen donor and/or lower genetic diversity of the pollen in families with poorer germination percentage could explain the found relationship. As, neither an inbreeding nor outbreeding depression could be confirmed by the data, investigation focusing on these effects would be needed, as both effects could occur in the progeny. Indications of inbreeding depression were given by the high proportion of hollow seeds, in some families reaching approx. $75 \%$. Inbreed embryos are known to be aborted in conifers and responsible for the observed high outcrossing rates (Woods and Heaman 1989; Kärkkäinen et al. 1999; Mullin et al. 2019). Yet, it cannot be confirmed with genetic analysis due to absence of material to study. For the mating within the stand, i.e. for seeds with assigned paternal tree, pollen dispersal was clearly distant depending, with most mating events occurred in $0-20$ meters. Further, a high outcrossing rate $(97,9 \%-99,7 \%)$ was estimated for the seed lot, with a high proportion of at least $70 \%$ of immigrant pollen contributed to the pooled progeny. The surrounding stands, from which this pollen likely originate, are comprised of putative planted trees most likely of different provenance(s). Thus, influence on the genetic composition and decrease of adaptation of the progeny compart to the parental stand is likely to occur. Especially, as the adaptive difference between mountainous stands of native and introduced provenances had been shown (Caré et al. 2020a). To assess the effect on the in situ conservation of stands of high elevation provenance, however the natural regeneration and younger trees needs to be studied as natural selection might counterbalance or at least lower the effect of immigrant gene-flow. In terms of the utilisation as a seed source such high amounts of immigrant pollen nonetheless can be seen with concern. However, seed trees located in the stand centre have in average lower external pollen influence. As a preliminary recommendation, seed harvest should be conducted within the stands centre if enough seed trees are available to ensure the maintenance of genetic diversity. For reliable prognoses further studies on this topic are nevertheless required. (Ch.III, Caré et al. 2020b) 


\subsection{References}

Ahuja I, Kissen R, Bones AM (2012) Phytoalexins in defense against pathogens. Trends Plant Sci 17:73-90. https://doi.org/10.1016/j.tplants.2011.11.002

Alakärppä E, Salo HM, Valledor L, Cañal MJ, Häggman H, Vuosku J (2018) Natural variation of DNA methylation and gene expression may determine local adaptations of Scots pine populations. J Exp Bot 69:5293-5305. https://doi.org/10.1093/jxb/ery292

Andersson E (1965) Cone and seed studies in Norway spruce (Pices abies (L.) KARST). Studia Forestalia Suecica 23

Antao T, Lopes A, Lopes RJ, Beja-Pereira A, Luikart G (2008) LOSITAN: A workbench to detect molecular adaptation based on a $F_{s t}$-outlier method. BMC Bioinformatics 9:323. https://doi.org/10.1186/1471-2105-9-323

Apostol EN, Budeanu M (2019) Adaptability of narrow-crowned Norway spruce ideotype (Picea abies (L.) KARST. pendula form) in 25 years half-sib comparative trials in the eastern Carpathians. Forests 10:395. https://doi.org/10.3390/f10050395

Axelsson EP, Senior JK (2018) The extended consequences of genetic conductivity: Mating distance affects community phenotypes in Norway spruce. Ecol Evol 8:11645-11655. https://doi.org/10.1002/ece3.4616

Baison J, Vidalis A, Zhou L, Chen Z, Li Z, Sillanpää MJ, Bernhardsson C, Scofield D, Forsberg N, Grahn T, Olsson L, Karlsson B, Wu H, Ingvarsson PK, Lundqvist S, Niittylä T, García-Gil MR (2019) Genome-wide association study identified novel candidate loci affecting wood formation in Norway spruce. Plant J 100:83-100. https://doi.org/10.1111/tpj.14429

Bayerische Staatsforsten (ed) (2009) Bewirtschaftung von Fichten- und Fichtenmischbeständen im Bayerischen Staatswald. Bayerische Staatsforsten, Regensburg

Bennett RN, Wallsgrove RM (1994) Secondary metabolites in plant defence mechanisms. New Phytol 127:617-633. https://doi.org/10.1111/j.1469-8137.1994.tb02968.x

Berendt F, Fortin M, Jaeger D, Schweier J (2017) How climate change will affect forest composition and forest operations in Baden-Württemberg-A GIS-based case study approach. Forests 8:298. https://doi.org/10.3390/f8080298

Berrill J, Libby WJ (2016) Comparing growth and form of coast Redwood selfs and outcrosses. Proceedings of the Coast Redwood Science Symposium, September 13-15, 2016, Eureka, California. 229-240

Bínová Z, Korecký J, Dvořák J, Bílý J, Zádrapová D, Jansa V, Lstibůrek M (2020) Genetic structure of Norway spruce ecotypes studied by SSR markers. Forests 11:10-12. https://doi.org/10.3390/f11010110

Bradbury PJ, Zhang Z, Kroon DE, Casstevens TM, Ramdoss Y, Buckler ES (2007) TASSEL: software for association mapping of complex traits in diverse samples. Bioinformatics 23:2633-2635. https://doi.org/10.1093/bioinformatics/btm308

Brang P, Pluess A, Bürgi A, Born J (2016) Potenzial von Gastbaumarten bei der Anpassung an den Klimawandel. In: Pluess AR, Augustin S, Brang P (eds) Wald im Klimawandel. Grundlagen für Adaptationsstrategien. Bundesamt für Umwelt BAFU; Eidg. Forschungsanstalt WSL, Bern; Stuttgart, pp 385-405

Brommer JE (2011) Whither $P_{S T}$ ? The approximation of $Q_{S T}$ by $P_{S T}$ in evolutionary and conservation biology. J Evol Biol 24:1160-1168. https://doi.org/10.1111/j.1420-9101.2011.02268.x

Budeanu M, Apostol EN, Popescu F, Postolache D, loniţă L (2019) Testing of the narrow crowned Norway spruce ideotype (Picea abies f. pendula) and the hybrids with normal crown form (pyramidalis) in multisite comparative trials. Sci Total Environ 689:980-990. https://doi.org/10.1016/j.scitotenv.2019.06.518

Bunting MJ, Twiddle CL, Middleton R (2008) Using models of pollen dispersal and deposition in hilly landscapes: Some possible approaches. Palaeogeogr Palaeoclimatol Palaeoecol 259:77-91. https://doi.org/10.1016/j.palaeo.2007.03.051

Burczyk J, Lewandowski A, Chalupka W (2004) Local pollen dispersal and distant gene flow in Norway spruce (Picea abies [L.] KARST.). For Ecol Manage 197:39-48. https://doi.org/10.1016/j.foreco.2004.05.003

Caré O, Gailing O, Müller M, Krutovsky K V., Leinemann L (2020a) Crown morphology in Norway spruce (Picea abies [KARST.] L.) as adaptation to mountainous environments is associated with single nucleotide polymorphisms (SNPs) in genes regulating seasonal growth rhythm. Tree Genet Genomes 16:4. https://doi.org/10.1007/s11295-019-1394-x

Caré O, Gailing O, Müller M, Krutovsky K V, Leinemann L (2020b) Mating system in a native Norway spruce (Picea abies [L.] KARST.) stand-Relatedness and effective pollen population size show an association with the germination percentage of single tree progenies. Diversity 12:266. https://doi.org/10.3390/d12070266

Caré O, Müller M, Vornam B, Höltken A, Kahlert K, Krutovsky K, Gailing O, Leinemann L (2018) High morphological differentiation in crown architecture contrasts with low population genetic structure of German Norway spruce stands. Forests 9:752. https://doi.org/10.3390/f9120752

Chen J, Källman T, Ma X-F, Zaina G, Morgante M, Lascoux M (2016) Identifying genetic signatures of natural selection using pooled population sequencing in Picea abies. G3 Genes, Genomes, Genet 6:1979-1989. https://doi.org/10.1534/g3.116.028753

Chen J, Tsuda Y, Stocks M, Källman T, Xu N, Kärkkäinen K, Huotari T, Semerikov VL, Vendramin GG, Lascoux M (2014) Clinal variation at phenology-related genes in spruce: Parallel evolution in FTL2 and Gigantea? Genetics 197:1025-1038. https://doi.org/10.1534/genetics.114.163063 
Chen J, Uebbing S, Gyllenstrand N, Lagercrantz U, Lascoux M, Källman T (2012) Sequencing of the needle transcriptome from Norway spruce (Picea abies KARST L.) reveals lower substitution rates, but similar selective constraints in gymnosperms and angiosperms. BMC Genomics 13:589. https://doi.org/10.1186/1471-216413-589

Chevarria MV (2005) Genetic characterisation of populations from the European natural range of Norway spruce (Picea abies ( L .) KARST .) by means of EST markers. Dissertation. Technischen Universität München. Munich, Germany. 09.03.2005

Chmura DJ (2006) Phenology differs among Norway spruce populations in relation to local variation in altitude of maternal stands in the Beskidy Mountains. New For 32:21-31. https://doi.org/10.1007/s11056-005-3390-2

Cooke JEK, Eriksson ME, Junttila O (2012) The dynamic nature of bud dormancy in trees: Environmental control and molecular mechanisms. Plant, Cell Environ 35:1707-1728. https://doi.org/10.1111/j.1365-3040.2012.02552.x

Dar TA, Uddin M, Khan MMA, Hakeem KR, Jaleel H (2015) Jasmonates counter plant stress: A review. Environ Exp Bot 115:49-57. https://doi.org/10.1016/j.envexpbot.2015.02.010

del Castillo RF, Trujillo-Argueta S, Sánchez-Vargas N, Newton AC (2011) Genetic factors associated with population size may increase extinction risks and decrease colonization potential in a keystone tropical pine. Evol Appl 4:574-588. https://doi.org/10.1111/j.1752-4571.2010.00177.x

Deleuze C, Hervé J-CC, Colin F, Ribeyrolles L, Herve JC, Colin F, Ribeyrolles L (1996) Modelling crown shape of Picea abies: Spacing effects. Can J For Res 26:1957-1966. https://doi.org/10.1139/×26-221

Di-Giovanni F, Beckett PM, Flenley JR (1989) Modelling of dispersion and deposition of tree pollen within a forest canopy. Grana 28:129-139. https://doi.org/10.1080/00173138909429964

Di Pierro EA, Mosca E, González-Martínez SC, Binelli G, Neale DB, La Porta N (2017) Adaptive variation in natural Alpine populations of Norway spruce (Picea abies [L.] KARST) at regional scale: Landscape features and altitudinal gradient effects. For Ecol Manage 405:350-359. https://doi.org/10.1016/j.foreco.2017.09.045

Di Pierro EA, Mosca E, Rocchini D, Binelli G, Neale DB, La Porta N (2016) Climate-related adaptive genetic variation and population structure in natural stands of Norway spruce in the South-Eastern Alps. Tree Genet Genomes 12:1-15. https://doi.org/10.1007/s11295-016-0972-4

Drushka K (2003) Canada's Forests- A history, 1st edn. McGill-Queen's University Press, Montreal \& Kingston, London, Ithaca

Fowler DP, Park YS (1983) Population studies of white spruce. I. Effects of self-pollination. Can J For Res 13:11331138. https://doi.org/10.1139/x83-151

Fyfe R (2006) GIS and the application of a model of pollen deposition and dispersal: A new approach to testing landscape hypotheses using the POLLANDCAL models. J Archaeol Sci 33:483-493. https://doi.org/10.1016/j.jas.2005.09.005

Galović V, Šijačić-Nikolić M, Šafhauzer R, Čortan D, Orlović S (2015) Genetic differentiation of Norway spruce (Picea abies (L.) KARST.) trees with diferent crown types from the mountain Golija. Genetika 47:849-861. https://doi.org/10.2298/GENSR1503849G

Ganthaler A, Stöggl W, Kranner I, Mayr S (2017a) Foliar phenolic compounds in Norway spruce with varying susceptibility to Chrysomyxa rhododendri: Analyses of seasonal and infection-induced accumulation patterns. Front Plant Sci 8:1-9. https://doi.org/10.3389/fpls.2017.01173

Ganthaler A, StöggI W, Mayr S, Kranner I, Schüler S, Wischnitzki E, Sehr EM, Fluch S, Trujillo-Moya C (2017b) Association genetics of phenolic needle compounds in Norway spruce with variable susceptibility to needle bladder rust. Plant Mol Biol 94:229-251. https://doi.org/10.1007/s11103-017-0589-5

Geburek T, Robitschek K, Milasowszky N (2008) A tree of many faces: Why are there different crown types in Norway spruce (Picea abies [L.] KARST.)? Flora Morphol Distrib Funct Ecol Plants 203:126-133. https://doi.org/10.1016/j.flora.2007.01.003

Geburek T, Robitschek K, Milasowszky N, Schadauer K (2007) Different cone colours pay off: Lessons learnt from European larch (Larix decidua) and Norway spruce (Picea abies). Can J Bot 85:132-140. https://doi.org/10.1139/B07-003

Gerendiain AZ, Peltola H, Pulkkinen P, Ikonen VP, Jaatinen R (2008) Differences in growth and wood properties between narrow and normal crowned types of Norway spruce grown at narrow spacing in Southern Finland. Silva Fenn 42:423-427. https://doi.org/10.14214/sf.247

Gillet EM (2013) DifferInt : compositional differentiation among populations at three levels of genetic integration. Mol Ecol Resour 13:953-964. https://doi.org/10.1111/1755-0998.12145

Gillet EM, Ziehe M, Gregorius HR (2016) Detecting differential viability selection between environments by analysis of compositional differentiation at different levels of genetic integration. Silvae Genet 65:17-29. https://doi.org/10.1515/sg-2016-0013

Gömöry D (1992) Effect of stand origin on the genetic diversity of Norway spruce (Picea abies KARST.) populations. For Ecol Manage 54:215-223. https://doi.org/10.1016/0378-1127(92)90014-Z

Gömöry D, Foffová E, Kmet J, Longauer R, Romšáková I (2010) Norway spruce (Picea abies [L.] KARST.) Provenance variation in autumn cold hardiness: Adaptation or acclimation? Acta Biol Cracoviensia Ser Bot 52:42-49. https://doi.org/10.2478/v10182-010-0022-8

Gonzalez JR, Armengol L, Sole X, Guino E, Mercader JM, Estivill X, Moreno V (2007) SNPassoc: an R package to perform whole genome association studies. Bioinformatics 23:654-655. https://doi.org/10.1093/bioinformatics/btm025 
Gori Y, La Porta N, Camin F (2013) Tree-ring isotope analysis of Norway spruce suffering from long-term infection by the pathogenic white-rot fungus Heterobasidion parviporum. For Pathol 44:160-162. https://doi.org/10.1111/efp.12089

Goto S, lijima H, Ogawa H, Ohya K (2011) Outbreeding depression caused by intraspecific hybridization between local and nonlocal genotypes in Abies sachalinensis. Restor Ecol 19:243-250. https://doi.org/10.1111/j.1526100X.2009.00568.x

Grassi G, Giannini R (2005) Influence of light and competition on crown and shoot morphological parameters of Norway spruce and silver fir saplings. Ann For Sci 62:269-274. https://doi.org/10.1051/forest:2005019

Gray LK, Hamann A (2011) Strategies for reforestation under uncertain future climates: Guidelines for Alberta, Canada. PLoS One 6:e22977. https://doi.org/10.1371/journal.pone.0022977

Greger O (1992) Erfassung von Reliktvorkommen des autochtonen Fichtenvorkommens im Hochharz. Dissertation. Georg-August-Universität, Göttingen, Germany, 1992.

Gregorius H-R, Roberds JH (1986) Measurement of genetical differentiation among subpopulations. Theor Appl Genet 71:826-834. https://doi.org/10.1007/BF00276425

Gruber F (1989) Phänotypen der Fichte (Picea abies (L.) KARST.). I. Verzweigungsphänotypen: Genotyp und Modifikation. Allg Forst- u J-Ztg 160:157-165

Gruber F (1993) Verzweigungssystem, Benadelung und Nadelfall der Fichte (Picea abies). ecomed, Landsberg am Lech

Guisan A, Theurillat JP (2001) Potential impact of climate change on vegetation in the european alps: a review. Clim Change 50:77-109. https://doi.org/10.1023/A:1010632015572

Gyllenstrand N, Karlgren A, Clapham D, Holm K, Hall A, Gould PD, Källman T, Lagercrantz U (2014) No time for spruce: Rapid dampening of circadian rhythms in Picea abies (L. KARST). Plant Cell Physiol 55:535-550. https://doi.org/10.1093/pcp/pct199

Gyllenstrand N, Morgante M, Neale D, Eckert A, Ma X, Chen J, Kallman T, Lascoux M, Lagercrantz U, Wegrzyn J, Zaina G, Bousquet J, Källman T, Ma X, Gyllenstrand N, Zaina G, Morgante M, Bousquet J, Eckert A, Wegrzyn J, Neale D, Lagercrantz U, Lascoux M (2012) Disentangling the roles of history and local selection in shaping clinal variation of allele frequencies and gene expression in Norway spruce (Picea abies). Genetics 191:865881. https://doi.org/10.1534/genetics.112.140749

Hanewinkel M, Cullmann DA, Schelhaas M, Nabuurs G, Zimmermann NE (2012) Climate change may cause severe loss in the economic value of European forest land. Nat Clim Chang 3:203-207. https://doi.org/10.1038/nclimate1687

Hannerz M, Westin J (2005) Autumn frost hardiness in Norway spruce plus tree progeny and trees of the local and transferred provenances in central Sweden. Tree Physiol 25:1181-1186. https://doi.org/10.1093/treephys/25.9.1181

Härt FH, Barka I, Hahn WA, Hlásny T, Irauschek F, Knoke T, Lexer MJ, Griess VC (2015) Multifunctionality in European mountain forests - An optimization under changing climatic conditions. Can J For Res 46:163-171. https://doi.org/10.1139/cjfr-2015-0264

Hasel K (1993) Zur Geschichte der Waldverwüstung in Deutschland und ihrer Überwindung durch Forstwirtschaft. Zeitschrift für Wirtschaftsgeographie 37:117-125. https://doi.org/10.1515/zfw.1993.0012

Heer K, Ullrich KK, Liepelt S, Rensing SA, Zhou J, Ziegenhagen B, Opgenoorth L (2016) Detection of SNPs based on transcriptome sequencing in Norway spruce (Picea abies (L.) KARST). Conserv Genet Resour 8:105-107. https://doi.org/10.1007/s12686-016-0520-4

Heuertz M, De Paoli E, Källman T, Larsson H, Jurman I, Morgante M, Lascoux M, Gyllenstrand N (2006) Multilocus patterns of nucleotide diversity, linkage disequilibrium and demographic history of Norway spruce [Picea abies (L.) KARST]. Genetics 174:2095-2105. https://doi.org/10.1534/genetics.106.065102

Hodkinson ID (2005) Terrestrial insects along elevation gradients: Species and community responses to altitude. Biol Rev Camb Philos Soc 80:489-513. https://doi.org/10.1017/S1464793105006767

Holliday JA, Wang T, Aitken S (2013) Predicting Adaptive Phenotypes From Multilocus Genotypes in Sitka Spruce (Picea sitchensis) Using Random Forest. G3 Genes|Genomes|Genetics 2:1085-1093. https://doi.org/10.1534/g3.112.002733

Ibáñez C, Kozarewa I, Johansson M, Ogren E, Rohde A, Eriksson ME (2010) Circadian clock components regulate entry and affect exit of seasonal dormancy as well as winter hardiness in Populus trees. Plant Physiol 153:1823-1833. https://doi.org/10.1104/pp.110.158220

Jansen S, Konrad H, Geburek T (2017) The extent of historic translocation of Norway spruce forest reproductive material in Europe. Ann For Sci 74:. https://doi.org/10.1007/s13595-017-0644-z

Jeandet P, Delaunois B, Conreux A, Donnez D, Nuzzo V, Cordelier S, Clément C, Courot E (2010) Biosynthesis, metabolism, molecular engineering, and biological functions of stilbene phytoalexins in plants. BioFactors 36:331-341. https://doi.org/10.1002/biof.108

Jeandroz S, Collignon AM, Favre JM (2004) RAPD and mtDNA variation among autochthonous and planted populations of Picea abies from the Vosges mountains (France) in reference to other French populations. For Ecol Manage 197:225-229. https://doi.org/10.1016/j.foreco.2004.05.015

Jetschke G (2019) Oberhofer Schlossberg-Fichten und Methusalem-Kiefern von Paulinzella: zwei bemerkenswerte Altbestände von Nadelbäumen. ThüringenForst-Anstalt öffentlichen Rechts: Erfurt, Germany, (accepted); Mitteilungen 37/2019 
Jofuku KD, den Boer BG, Van Montagu M, Okamuro JK (1994) Control of Arabidopsis flower and seed development by the homeotic gene APETALA2. Plant Cell 6:1211-1225. https://doi.org/10.1105/tpc.6.9.1211

Johnsen $\varnothing$, Fossdal CG, Nagy N, MøImann J, Dæhlen OG, Skrøppa T (2005) Climatic adaptation in Picea abies progenies is affected by the temperature during zygotic embryogenesis and seed maturation. Plant, Cell Environ 28:1090-1102. https://doi.org/10.1111/j.1365-3040.2005.01356.x

Johnsen, Skrøppa T, Junttila O, Dæhlen OG (1996) Influence of the female flowering environment on autumn frosthardiness of Picea abies progenies. Theor Appl Genet 92:797-802. https://doi.org/10.1007/s001220050195

Jokipii-Lukkari S, Delhomme N, Schiffthaler B, Mannapperuma C, Prestele J, Nilsson O, Street NR, Tuominen H (2018) Transcriptional roadmap to seasonal variation in wood formation of Norway spruce. Plant Physiol 176:2851-2870. https://doi.org/10.1104/pp.17.01590

Jombart T, Devillard S, Balloux F (2010) Discriminant analysis of principal components: a new method for the analysis of genetically structured populations. BMC Genet. https://doi.org/doi:10.1186/1471-2156-11-94

Jombart T, Devillard S, Dufour AB, Pontier D (2008) Revealing cryptic spatial patterns in genetic variability by a new multivariate method. Heredity (Edinb) 101:92-103. https://doi.org/10.1038/hdy.2008.34

Jongejans E, Skarpaas O, Shea K (2008) Dispersal, demography and spatial population models for conservation and control management. Perspect Plant Ecol Evol Syst 9:153-170. https://doi.org/10.1016/j.ppees.2007.09.005

Kalela A (1937) Zur Synthesse er experimentellen Untersuchungen über Klimarassen der Holzarten. Communications Instituti Forestalis Fenniae: Helsinki, Finland

Kalinowski ST, Taper ML, Marshall TC (2007) Revising how the computer program cervus accommodates genotyping error increases success in paternity assignment. Mol Ecol 16:1099-1106. https://doi.org/10.1111/j.1365294X.2007.03089.x

Källman T, De Mita SS, Larsson H, Gyllenstrand N, Heuertz M, Parducci L, Suyama Y, Lagercrantz U, Lascoux M (2014) Patterns of nucleotide diversity at photoperiod related genes in Norway spruce [Picea abies (L.) KARST.]. PLoS One 9:1-10. https://doi.org/10.1371/journal.pone.0095306

Kärkkäinen K, Savolainen O, Koski V (1999) Why do plants abort so many developing seeds: bad offspring or bad maternal genotypes? Evol Ecol 13:305-317. https://doi.org/10.1023/A:1006746900736

Kathke S, Bruelheide H (2011) Differences in frost hardiness of two Norway spruce morphotypes growing at Mt. Brocken, Germany. Flora Morphol Distrib Funct Ecol Plants 206:120-126. https://doi.org/10.1016/j.flora.2010.09.007

Khuri S, Shmoury MR, Baalbaki R, Maunder M, Talhouk SN (2000) Conservation of the Cedrus libani populations in Lebanon: history, current status and experimentalapplication of somatic embryogenesis. Biodivers Conserv 9:1261-1273. https://doi.org/10.1023/A:1008936104581

Kiellander CL (1962) Picea, Abies, Pseudozuga. In: founded by Th. Roemer and W. Rudolf edited by H. Kappert and W. Rudorf (ed) Manual of Plant Breeding VI-Breeding of Legumes and Fruits, Viniculture and Silviculture, 2nd edn. P. Parey, Berlin, Hamburg, pp 854-873

Kirby KJ, Watkins C (eds) (1998) The ecological history of European forests. CAB International, New York

Kleine T (2012) Arabidopsis thaliana mTERF proteins: evolution and functional classification. Front Plant Sci 3:1-15. https://doi.org/10.3389/fpls.2012.00233

Knoke T (2009) Die ökonomische Zukunft der Fichte. LWF Wissen 63:16-21

Knoke T, Ammer C, Stimm B, Mosandl R (2008) Admixing broadleaved to coniferous tree species: A review on yield, ecological stability and economics. Eur J For Res 127:89-101. https://doi.org/10.1007/s10342-007-0186-2

Kölling C, Knoke T, Schall P, Ammer C (2009) Cultivation of Norway spruce (Picea abies (L.) KARST.) in Germany: considerations on risk against the background of climate change (original title in German: Überlegungen zum Risiko des Fichtenanbaus in Deutschland vor dem Hintergrund des Klimawandels). Forstarchiv 80:42-54

König A (2002) Growth and snowbreak damage of Norway spruce provenances from Poland under harsh site conditions. In: Meier-Dinkel A, Steiner W (eds) Forest tree breeding in an ecologically oriented forest management system. Schriften Forstlichen Fakultät Universität Göttingen und der Niedersächsischen Forstlichen Versuchsanstalt. Sauerländer, Frankfurt am Main, pp 139-150

Kopelman NM, Mayzel J, Jakobsson M, Rosenberg NA, Mayrose I (2015) Clumpak: A program for identifying clustering modes and packaging population structure inferences across K. Mol Ecol Resour 15:1179-1191. https://doi.org/10.1111/1755-0998.12387

Körner C (2003) Alpine plant life: functional plant ecology of high mountain ecosystems, 2nd edn. Springer, Berlin Krutovsky K, Burczyk J, Chybicki I (2012) Gene flow, spatial structure, local adaptation, and assisted migration in trees. In: Schnell RJ, Priyadarshan PM (eds) Genomics of tree crops. Springer New York Heidelberg Dordrecht London, pp 71-116

Kuittinen H, Savolainen O (1992) Picea omorika is a self-fertile but outcrossing conifer. Heredity (Edinb) 68:183-187. https://doi.org/10.1038/hdy.1992.27

Kujala ST, Savolainen O (2012) Sequence variation patterns along a latitudinal cline in Scots pine (Pinus sy/vestris): signs of clinal adaptation? Tree Genet Genomes 8:1451-1467. https://doi.org/10.1007/s11295-012-0532-5

Landesbetrieb Forst Baden-Württemberg, Ministerium für Ländlichen Raum und Verbraucherschutz BadenWürttemberg (eds) (2014) Forst BW Praxis - Richtlinie Landesweiter Waldentwicklungstypen. Landesbetrieb Forst Baden-Württemberg, Ministerium für Ländlichen Raum und Verbraucherschutz Baden-Württemberg, Stuttgart 
Landesbetrieb HessenForst (ed) (2016) Hessische Waldbaufibel- Grundsätze und Leitlinien zur naturnahen Wirtschaftsweise im hessischen Staatswald. Kassel

Landesforsten Niedersächsische (ed) (2011) Das LÖWE-Programm. Niedersächsische Landesforsten, Braunschweig

Leinonen I, Hänninen H (2002) Adaptation of the timing of bud burst of Norway spruce to temperate and boreal climates. Silva Fenn 36:695-701

Leinonen T, McCairns RJS, O'Hara RB, Merilä J (2013) $Q_{S T}-F_{S T}$ comparisons: evolutionary and ecological insights from genomic heterogeneity. Nat Rev Genet 14:179-190. https://doi.org/10.1038/nrg3395

Liesebach M, Rau H, König AO (2010) Fichtenherkunftsversuch von 1962 und IUFRO-Fichtenherkunftsversuch von 1972 - Ergebnisse von mehr als 30-jähriger Beobachtung in Deutschland. Nordwestdeutsche Forstliche Versuchsanstalt (NW-FVA): Göttingen, Germany

Lind M, Källman T, Chen J, Ma XF, Bousquet J, Morgante M, Zaina G, Karlsson B, Elfstrand M, Lascoux M, Stenlid J (2014) A Picea abies linkage map based on SNP markers identifies QTLS for four aspects of resistance to Heterobasidion parviporum infection. PLoS One 9:. https://doi.org/10.1371/journal.pone.0101049

Lynch M (1991) The Genetic Interpretation of Inbreeding Depression and Outbreeding Depression. Evolution (N Y) 45:622. https://doi.org/10.2307/2409915

MacCleery DW (1992) American forests : A history of resiliency and recovery. Forest History Society, Durham, North Carolina

Máchová P, Trčková O, Cvrčková H (2018) Use of nuclear microsatellite loci for evaluating genetic diversity of selected populations of Picea abies (L.) KARSTEN in the Czech republic. Forests 9:92. https://doi.org/10.3390/f9020092

Maghuly F, Pinsker W, Praznik W, Fluch S (2006) Genetic diversity in managed subpopulations of Norway spruce [Picea abies (L.) KARST.]. For Ecol Manage 222:266-271. https://doi.org/10.1016/j.foreco.2005.10.025

Mátyás C (2004) Population, conservation and ecological genetics. In: Burley J, Evans J, Youngquist JA (eds) Encyclopedia of forest sciences. Vol.1. Elsevier, Amsterdam, pp 188-197

McGrath MJ, Luyssaert S, Meyfroidt P, Kaplan JO, Bürgi M, Chen Y, Erb K, Gimmi U, Mclnerney D, Naudts K, Otto J, Pasztor F, Ryder J, Schelhaas MJ, Valade A (2015) Reconstructing European forest management from 1600 to 2010. Biogeosciences 12:4291-4316. https://doi.org/10.5194/bg-12-4291-2015

Mergen F, Burley J, Furnival GM (1965) Embryo and seedling development in Picea glauca (MOENCH) Voss after self-, cross-, and wind-pollination. Silvae Genet 14:188-194

Miao Z, Zhao P, Mao J, Yu L, Yuan Y, Tang H, Liu Z (2018) HOMEOBOX PROTEIN52 Mediates the crosstalk between ethylene and auxin signaling during primary root elongation by modulating auxin transport-related gene expression. 30:2761-2778. https://doi.org/10.1105/tpc.18.00584

Mitton JB, Williams CG (2006) Gene flow in conifers. In: Williams C (ed) Landscapes, genomics and transgenic conifers. Managing Forest Ecosystems. Springer, Dordrecht, pp 147-168

Modrzyński J, Eriksson G (2002) Response of Picea abies populations from elevational transects in the Polish Sudety and Carpathian mountains to simulated drought stress. For Ecol Manage 165:105-116. https://doi.org/10.1016/S0378-1127(01)00651-X

Möhring B, Wilhelm S (2015) Nadelholz - ökonomische Basis für Forstbetriebe. AFZ-DerWald 17/2015:202-203

Möllmann TB, Möhring B (2017) A practical way to integrate risk in forest management decisions. Ann For Sci 74:75. https://doi.org/10.1007/s13595-017-0670-x

Mosca E, Di Pierro EA, Budde KB, Neale DB, González-Martínez SC (2018) Environmental effects on fine-scale spatial genetic structure in four Alpine keystone forest tree species. Mol Ecol 1-12. https://doi.org/10.1111/mec.14469

Müller-Starck G (1995) Genetic variation in high elevated populations of Norway spruce (Picea abies (L.) KARST.) in Switzerland. Silvae Genet. 44:356-362

Müller-Starck G, Ziehe M, Schubert R (2005) Genetic diversity parameters associated with viability selection, reproductive efficiency, and growth in forest tree species. In: Scherer-Lorenzen $M$, Körner C, Schulze ED (eds) Forest diversity and function. Springer-Verlag, Berlin Heidelberg, pp 87-108

Mullin TJ, Persson T, Abrahamsson S, Gull BA (2019) Effects of inbreeding depression on seed production in scots pine (Pinus sylvestris). Can J For Res 49:854-860. https://doi.org/10.1139/cjfr-2019-0049

Namroud MC, Beaulieu J, Juge N, Laroche J, Bousquet J (2008) Scanning the genome for gene single nucleotide polymorphisms involved in adaptive population differentiation in white spruce. Mol Ecol 17:3599-3613. https://doi.org/10.1111/j.1365-294X.2008.03840.x

Nilsson L, Carlsbecker A, Sundås-Larsson A, Vahala T (2007) APETALA2 like genes from Picea abies show functional similarities to their Arabidopsis homologues. Planta 225:589-602. https://doi.org/10.1007/s00425-006-03741

Nykänen ML, Peltola H, Quine C, Kellomäki S, Broadgate M (1997) Factors affecting snow damage of trees with particular reference to European conditions. Silva Fenn 31:193-213. https://doi.org/10.14214/sf.a8519

Oosthoek JK, Richard H (eds) (2018) Managing northern europe's forests: Histories from the age of improvement to the age of ecology. Berghahn Books, New York; Oxford

Pârnuţă G (2003) Researchs concerning narrow-crowned spruce ideotypes (Picea abies f . pendula (LAWSON) SYLVEN ) in Romania. Analele ICAS 46:109-122 
Paul C, Brandl S, Friedrich S, Falk W, Härtl F, Knoke T (2019) Climate change and mixed forests: how do altered survival probabilities impact economically desirable species proportions of Norway spruce and European beech? Ann For Sci 76:14. https://doi.org/10.1007/s13595-018-0793-8

Paul M, Hinrichs T, Janßen A, Schmitt H-P, Soppa B, Stephan R, Dörflinger H (2010) Forest genetic resources in Germany-Concept for the conservation and sustainable utilization of forest genetic resources in the federal republic of Germany, Updated ed. BMELV, Bonn

Pöykkö VT, Pulkkinen PO (1990) Characteristics of normal-crowned and pendula spruce (Picea abies (L.) KARST.) examined with reference to the definition of a crop tree ideotype. Tree Physiol 7:201-207. https://doi.org/10.1093/treephys/7.1-2-3-4.201

Pretzsch H, Schütze G, Uhl E (2013) Resistance of European tree species to drought stress in mixed versus pure forests: evidence of stress release by inter-specific facilitation. Plant Biol 15:483-495. https://doi.org/10.1111/j.1438-8677.2012.00670.x

Priehäusser G (1958) Die Fichten-Variationen und -Kombinationen des Bayr. Waldes nach phänotypischen Merkmalen mit Bestimmungsschlüssel. Forstwissenschaftliches Cent 77:151-171. https://doi.org/10.1007/BF01829703

Pritchard JK, Stephens M, Donnelly P (2000) Inference of population structure using multilocus genotype data. Genetics 155:945-959. https://doi.org/10.1111/j.1471-8286.2007.01758.x

Prunier J, Laroche J, Beaulieu J, Bousquet J (2011) Scanning the genome for gene SNPs related to climate adaptation and estimating selection at the molecular level in boreal black spruce. Mol Ecol 20:1702-1716. https://doi.org/10.1111/j.1365-294X.2011.05045.x

Pulkkinen P, Pöykkö T (1990) Inherited narrow crown form, harvest index and stem biomass production in Norway spruce, Picea abies. Tree Physiol 6:381-391. https://doi.org/10.1093/treephys/6.4.381

Qamaruddin M, Dormling I, Ekberg I, Eriksson G, Tillberg E (1993) Abscisic acid content at defined levels of bud dormancy and frost tolerance in two contrasting populations of Picea abies grown in a phytotron. Physiol Plant 87:203-210. https://doi.org/10.1034/j.1399-3054.1993.870212.x

Quesada V (2016) The roles of mitochondrial transcription termination factors (MTERFs) in plants. Physiol Plant 157:389-399. https://doi.org/10.1111/ppl.12416

Radu RG, Curtu LA, Spârchez G, Şofletea N (2014) Genetic diversity of Norway spruce [Picea abies (L.) KARST.] in Romanian Carpathians. Ann For Res 57:19-29. https://doi.org/10.15287/afr.2014.178

Rasmann S, Pellissier L, Defossez E, Jactel H, Kunstler G (2014) Climate-driven change in plant-insect interactions along elevation gradients. Funct Ecol 28:46-54. https://doi.org/10.1111/1365-2435.12135

Rau HM, Schönfelder E (2008) Experiences of cultivation with Grand fir (Abies grandis LINDL.) provenances in Western Germany - Results of assessments on 18 sites at age 27. Austrian J For Sci 125:201-216

Ribera A., Zuñiga G (2012) Induced plant secondary metabolites for phytopatogenic fungi control: a review. J soil Sci plant Nutr 12:0-0. https://doi.org/10.4067/S0718-95162012005000040

Robles P, Micol JL, Quesada V (2012) Arabidopsis MDA1, a nuclear-encoded protein, functions in chloroplast development and abiotic stress responses. PLoS One 7:. https://doi.org/10.1371/journal.pone.0042924

Savolainen O, Lascoux M, Merilä J (2013) Ecological genomics of local adaptation. Nat Rev Genet 14:807-820. https://doi.org/10.1038/nrg3522

Scalfi M, Mosca E, Di Pierro EA, Troggio M, Vendramin GG, Sperisen C, La Porta N, Neale DB (2014) Micro-and macro-geographic scale effect on the molecular imprint of selection and adaptation in Norway spruce. PLoS One 9:1-22. https://doi.org/10.1371/journal.pone.0115499

Schaberg PG, DeHayes DH, Hawley GJ, Nijensohn SE (2008) Anthropogenic alterations of genetic diversity within tree populations: Implications for forest ecosystem resilience. For Ecol Manage 256:855-862. https://doi.org/10.1016/j.foreco.2008.06.038

Schmidt-Vogt H (1977) Taxonomie, Verbreitung, Morphologie, Ökologie, Waldgesellschaften. In: Die Fichte -Ein Handbuch in zwei Bänden; Bd. 1. Parey, Hamburg ; Berlin, p 647

Schröter C (1934) Übersicht über die Modifikationen der Fichte. Schweizerische Zeitschrift für Forstwesen 85:33-46

Schueler S, Schlünzen KH (2006) Modeling of oak pollen dispersal on the landscape level with a mesoscale atmospheric model. Environ Model Assess 11:179-194. https://doi.org/10.1007/s10666-006-9044-8

Scotti I, Paglia G, Magni F, Morgante M (2006) Population genetics of Norway spruce (Picea abies KARST.) at regional scale: sensitivity of different microsatellite motif classes in detecting differentiation. Ann For Sci 63:485-491. https://doi.org/10.1051/forest:2006029

Shigyo M, Hasebe M, Ito M (2006) Molecular evolution of the AP2 subfamily. Gene 366:256-265. https://doi.org/10.1016/j.gene.2005.08.009

Shigyo M, Ito M (2004) Analysis of gymnosperm two-AP2-domain-containing genes. Dev Genes Evol 214:105-114. https://doi.org/10.1007/s00427-004-0385-5

Shimono A, Wang XR, Torimaru T, Lindgren D, Karlsson B (2011) Spatial variation in local pollen flow and mating success in a Picea abies clone archive and their implications for a novel "breeding without breeding" strategy. Tree Genet Genomes 7:499-509. https://doi.org/10.1007/s11295-010-0351-5

Skröppa T (1996) Diallel crosses in Picea abies II. Perdormance and inbreeding depression of selfed families. Forest Genetics 3:69-79

Skrøppa T, Steffenrem A (2020) Variation among and within provenances of Norway spruce from Trøndelag and Nordland. NIBIO Rapport 6:10 
Spellmann H, Sutmöller J, Meesenburg H (2007) Risikovorsorge im Zeichen des Klimawandels. Vorläufige Empfehlungen der NW-FVA am Beispiel des Fichtenanbaus. AFZ-Der Wald 62:1246-1249

Spiecker H (2000) Growth of Norway spruce (Picea abies (L.) KARST.) under changing environmental conditions in Europe. In: Klimo E, Hager H, Kulhavý J (eds) Spruce monocultures in central Europe-Problems and prospects, EFI Proceedings No. 33. European Forest Institute, Joensuu, Finland, pp 11-27

Storey JD (2002) A direct approach to false discovery rates. J R Stat Soc Ser B (Statistical Methodol) 64:479-498. https://doi.org/10.1111/1467-9868.00346

Storey JD, Tibshirani R (2003) Statistical significance for genomewide studies. Proc Natl Acad Sci 100:9440-9445. https://doi.org/10.1073/pnas.1530509100

Sun L, Wang S, Xi J, Yang S, Liu X, Chai X, Xin H, An B, Haoi D (2009) A fractionation procedure for identifying novel proteins induced by chill stress in Arabidopsis thaliana. Biotechnol Lett 31:1289-1295. https://doi.org/10.1007/s10529-009-9985-5

Sylvén N (1909) Studier öfver granens formrikedom, särskildt dess förgreningstyper och deras skogliga värde. Statens Skogsförsöksanstalt: Stockholm, Sweden

Terhürne-Berson R (2005) Changing distribution patterns of selected conifers in the Quaternary of Europe caused by climatic variations. Dissertation. Friedrich-Wilhelms-Universität Bonn, Germany. 16.06.2005

Thünen-Institut (2014) Dritte Bundeswaldinventur - Ergebnisdatenbank. Auftragskürzel 77Z1JI_L244of_2012_bi, Arch. 2014-6-12 14348.660, Überschrift Vor. [1000 m³] nach L. und Baumartengruppe, Filter Jahr=2012. https://bwi.info. Accessed 24 Mar 2015

Tollefsrud MM, Kissling R, Gugerli F, Johnsen $\varnothing$, Skrøppa T, Cheddadi R, Van Der Knaap WO, Latałowa M, TerhürneBerson R, Litt T, Geburek T, Brochmann C, Sperisen C (2008) Genetic consequences of glacial survival and postglacial colonization in Norway spruce: Combined analysis of mitochondrial DNA and fossil pollen. Mol Ecol 17:4134-4150. https://doi.org/10.1111/j.1365-294X.2008.03893.x

Tollefsrud MM, Sønsteb $\varnothing \mathrm{JH}$, Brochmann C, Johnsen $\varnothing$, Skrøppa T, Vendramin GG (2009) Combined analysis of nuclear and mitochondrial markers provide new insight into the genetic structure of north European Picea abies. Heredity (Edinb) 102:549-562. https://doi.org/10.1038/hdy.2009.16

Unger GM, Konrad H, Geburek T (2011) Does spatial genetic structure increase with altitude? An answer from Picea abies in Tyrol, Austria. Plant Syst Evol 292:133-141. https://doi.org/10.1007/s00606-010-0407-x

Vitali V, Büntgen U, Bauhus J (2017) Silver fir and Douglas fir are more tolerant to extreme droughts than Norway spruce in south-western Germany. Glob Chang Biol 23:5108-5119. https://doi.org/10.1111/gcb.13774

Wilhelm B (1990) Die autochtonen Höhenfichten des Thüringer Waldes am Beispiel der Oberhofer SchloßbergFichte. AFZ 33-34:845-846

Williams CG (2010) Long-distance pine pollen still germinates after meso-scale dispersal. Am J Bot 97:846-855 https://doi.org/10.3732/ajb.0900255

Willige BC, Ahlers S, Zourelidou M, Barbosa ICR, Demarsy E, Trevisan M, Davis PA, Roelfsema MRG, Hangarter R, Fankhauser C, Schwechheimer C (2013) D6PK AGCVIII Kinases are required for auxin transport and phototropic hypocotyl bending in Arabidopsis. Plant Cell 25:1674-1688. https://doi.org/10.1105/tpc.113.111484

Wojacki J, Eusemann P, Ahnert D, Pakull B, Liesebach H (2019) Genetic diversity in seeds produced in artificial Douglas-fir (Pseudotsuga menziesii) stands of different size. For Ecol Manage 438:18-24. https://doi.org/10.1016/j.foreco.2019.02.012

Woods JH, Heaman JC (1989) Effect of different inbreeding levels on filled seed production in Douglas-fir. Can J For Res 19:54-59. https://doi.org/10.1139/x89-007

Wright JW (1952) Pollen dispersion of some forest trees. Station Paper 46. United States Department of Agriculture. Forest Service. Northeastern Forest Experiment Station. Upper Darby, Pennsylvania, USA

Xie CY, Knowles P (1994) Mating system and effective pollen immigration in a Norway spruce (Picea abies (L.) Karst) plantation. Silvae Genet 43:48-51

Zhang N, Shugart HH, Yan X (2009) Simulating the effects of climate changes on eastern Eurasia forests. Clim Change 95:341-361. https://doi.org/10.1007/s10584-009-9568-4

Zhou J, Luo J (2018) The PIN-FORMED auxin efflux carriers in plants. Int J Mol Sci 19:2759. https://doi.org $10.3390 /$ ijms 19092759 


\title{
5. Chapter I - High Morphological Differentiation in Crown Architecture Contrasts with Low Population Genetic Structure of German Norway Spruce Stands
}

Oliver Caré, Markus Müller, Barbara Vornam, Aki M. Höltken, Karina Kahlert, Konstantin V. Krutovsky, Oliver Gailing, Ludger Leinemann

\author{
Journal: $\quad$ Forests \\ Volume: $\quad 9$ \\ Issue: $\quad 12$ \\ Year: 2018 \\ Publisher: $\quad$ MDPI \\ Copyright: (C) by the authors under the terms and conditions of the Creative \\ Commons Attribution (CC BY) license \\ (https://creativecommons.org/licenses/by/4.0/) \\ Published: $\quad 04$ December 2018 \\ DOI: $\quad 10.3390 / f 9120752$ \\ URL: $\quad$ www.mdpi.com/1999-4907/9/12/752
}

Autor contributions:

Conceptualization: O.C., M.M, B.V., K.K., K.V.K., O.G. and L.L.; Methodology: O.C., M.M., B.V., O.G. and L.L.; Software: O.C.; Validation: O.C., M.M, B.V., K.V.K., O.G. and L.L.; Formal analysis: O.C.; Investigation: O.C.; Resources, K.K. and A.M.H.; Data curation: O.C.; Writing-original draft preparation: O.C.; Writing-review \& editing: O.C., M.M, B.V., A.M.H., K.K., K.V.K., O.G. and L.L.; Visualization: O.C.; Supervision: O.G. and L.L.; Project administration: O.G. and L.L.; Funding acquisition: M.M., B.V., O.G. and L.L. (listed based on position in author list, CRediT taxonomy) 


\title{
High Morphological Differentiation in Crown Architecture Contrasts with Low Population Genetic Structure of German Norway Spruce Stands
}

\author{
Oliver Caré ${ }^{1} \oplus$, Markus Müller ${ }^{1} \oplus$, Barbara Vornam ${ }^{1}$, Aki M. Höltken ${ }^{2}$, Karina Kahlert ${ }^{3}$, \\ Konstantin V. Krutovsky ${ }^{1,4,5,6} \oplus$, Oliver Gailing ${ }^{1, *}$ and Ludger Leinemann ${ }^{1}$ \\ 1 Department of Forest Genetics and Forest Tree Breeding, Büsgen-Institute, Faculty of Forest Sciences and \\ Forest Ecology, University of Göttingen, 37077 Göttingen, Germany; \\ oliver.care@forst.uni-goettingen.de (O.C.); mmuellef@gwdg.de (M.M.); bvornam1@gwdg.de (B.V.); \\ kkrutov@gwdg.de (K.V.K.); lleinem@gwdg.de (L.L.) \\ 2 Department of Forest Genetic Resources, Northwest German Forest Research Institute (NW-FVA), \\ 34346 Hann. Münden, Germany; aki.hoeltken@nw-fva.de \\ 3 Service and Competence Centre of Thüringen Forst, 99867 Gotha, Germany; \\ karina.kahlert@forst.thueringen.de \\ 4 Department of Ecosystem Science and Management, Texas A\&M University, College Station, TX 77840, USA \\ 5 Laboratory of population genetics, Vavilov Institute of General Genetics, Russian Academy of Sciences, \\ 119991 Moscow, Russia \\ 6 Genome Research and Education Centre, Siberian Federal University, 660036 Krasnoyarsk, Russia \\ * Correspondence: ogailin@gwdg.de
}

Received: 21 November 2018; Accepted: 30 November 2018; Published: 4 December 2018

\begin{abstract}
High elevation sites in the low mountain ranges in Germany are naturally covered by Norway spruce (Picea abies (Karst.) L.) stands. Historically, large scale anthropogenic range expansion starting in the mid to late 18th century had a huge impact on the forest composition throughout Germany. Utilisation and exploitation often led to artificial regeneration, mostly carried out using seeds from allochthonous provenances. Usually, autochthonous (natural) high elevation Norway spruce trees have narrow crown phenotypes, whereas lowland trees have broader crowns. Narrow crown phenotypes are likely the result of adaptation to heavy snow loads combined with high wind speeds. In the present study, neighbouring stand pairs of putative autochthonous and allochthonous origin with contrasting phenotypes in high elevation sites were investigated with 200 samples each. These stands are located in the Ore Mountains, the Thuringian Forest, and the Harz Mountains. Additionally, a relict population with the typical narrow high elevation phenotypes was sampled in Thuringia, known as "Schlossbergfichte". The objective of the study was to quantify supposedly adaptive phenotypic differences in crown architecture and the genetic differentiation of 11 putatively neutral nuclear microsatellite markers (i.e., simple sequence repeats (nSSRs)). The high differentiation of morphological traits $\left(P_{\mathrm{ST}}=0.952-0.989\right)$ between the neighbouring autochthonous and allochthonous stands of similar age contrasts with the very low neutral genetic differentiation $\left(F_{\mathrm{ST}}=0.002-0.007 ; G^{\prime \prime}{ }_{\mathrm{ST}}=0.002-0.030\right)$, suggesting that directional selection at adaptive gene loci was involved in phenotypic differentiation. Comparing the regions, a small isolation by distance effect for the Harz Mountains was detected, suggesting landscape resistance restricting gene flow. Finally, the differentiation of the very old autochthonous (up to 250 years) stand "Schlossbergfichte" with typical high elevation phenotypes could cohere with the sampling of a relict genepool.
\end{abstract}

Keywords: Picea abies; microsatellites; crown architecture; morphology; phenotypic adaptation; genetic differentiation 


\section{Introduction}

Genetic variation of neutral genetic markers across the distribution range of Norway spruce (Picea abies (Karst.) L.) is very high, but genetic differentiation is usually relatively low [1,2] and contrasts with the high phenotypic differentiation of crown architecture between low and high elevation varieties [3-5]. Autochthonous (natural) high elevation stands are characterised by narrow crowned individuals as a result of potential adaptation to heavy snow loads, while in allochthonous stands relatively recently planted in the same region, broad crown shapes are prevailing. High differentiation of phenotypic traits between neighbouring stands in the same environment, but low differentiation at randomly selected selectively neutral markers, would suggest directional selection on genes related to these phenotypic traits [6], which are crown architecture traits in our study.

Norway spruce is one of the economically most important tree species in Germany and has been widely planted since the late 18th century [7]. However, some autochthonous stands are still present in the low mountain ranges at higher elevations. One of these rare stands is located in Thuringia known as "Schlossbergfichte". This stand is characterised by very old native trees (up to 250 years) with typical narrow crown phenotypes, whereas trees of neighbouring allochthonous stands mostly show the broad low elevation phenotypes.

Before extensive translocation of seeding material occurred [8], variation in crown phenotypes and typical narrow crown phenotypes were described in natural spruce stands from northern latitudes [9,10]. Crown characteristics are crucial for the resistance to snow breakage and high wind speeds [11]. Hence, trees with a narrow crown shape are considered to be more adapted to climatic conditions in high elevations or regions with high snow loads [7,12-14]. This assumption is also supported by the finding of higher frequencies of narrow crowned trees in areas with a high snow break hazard [15]. In addition, association of crown architecture with temperature, altitude, and precipitation had previously been reported $[4,7,13]$. Moreover, trees with high elevation phenotypes showed a higher frost hardiness than low elevation phenotypes, while both "morphotypes" had sufficient frost tolerance to prevent late frost damage [16].

Sylvén [17] was one of the first who suggested that variation in crown shapes is heritable. The occurrence of neighbouring autochthonous and allochthonous stands with different crown shapes is a further indication of the heritability of crown shapes. Kiellander [18] suggested heritability of crown architecture based on a crossing experiment made in 1942 in Sweden. Common garden studies have also revealed that damages caused by snow loads were less frequent in trees representing provenances from higher altitudes than in those from lower altitudes [19]. In addition, decreasing susceptibility to late and early frost events, a lower height to diameter ratio (slenderness), probable resulting in the reported increased resistance to mechanical damages by snow, a reduced growth rate, and shorter and thicker needles are reported for higher altitude provenances [20]. However, direct measurements on crown architecture in common garden experiments and heritability estimates are missing. In a formal way, inheritance of crown architecture was only assessed for the pendulous variety of Norway spruce (Picea abies f. pendula). Segregation ratios in open pollinated progenies suggested that it is controlled by a single or by a few dominant genes [21] and linked to an RAPD (random amplified polymorphic DNA) marker [22].

Even though genetic differentiation across the species range is low, historical migration patterns can be reconstructed using neutral genetic markers and other evidence, such as pollen data. Pollen data suggest that the first larger populations in the Holocene occurred within present day Germany in the Alps around 8000-9000 years ago [23]. Macrofossils and pollen data give evidence for several potential refugia during the last glacial maximum, some of which had no contribution to the recolonization history, such as the Massif Central (France) or the Moldavian lowlands refugia [24]. Concurrently, different refugia are proposed as a source of re-immigration, as $P$. abies can be divided in two main (Baltico Nordic and Alpine Central Europe) and one minor (Carpathian) domains [2,25-29]. Combined analysis from mtDNA (mitochondrial DNA) and pollen data reveal a more detailed view that suggest at least seven refugia from which recolonization occurred [30]. Despite this distinction, 
the level of inter-population differentiation at nuclear markers remains relatively low, even on larger geographical scales of several hundred kilometres, which is likely caused by high rates of pollen mediated gene flow [31-34].

Genetic and morphological analyses of neighbouring Norway spruce populations, which are morphologically differentiated in their crown architecture at the same altitudinal level, are rare. The study by Greger [35] is the only example for an investigation of a possible link between crown morphology and genetic variation. More common are studies comparing stands or individuals along altitudinal transects without any specific information on crown architecture. Results from different sources showed no consistent pattern of genetic variation between low and high elevation stands. For example, Maghuly et al. [36] found a higher genetic diversity in high elevation type populations than in allochthonous middle and low elevation populations, at nuclear simple sequence repeats (nSSRs) and mitochondrial markers. The authors further found higher expected heterozygosity in older stands than in younger stands, at nSSRs. However, other studies found either no relationship between altitude and diversity [32] or the highest diversity in populations from intermediate elevations [37].

For the first time, neighbouring high elevation type and low elevation type stands in the same high elevation environment are analysed for crown phenotypes and genetic markers to estimate both neutral and potentially adaptive genetic variation. These stands are located in the low mountain range in Germany, in the regions of the Thuringian Forest, the Ore Mountains, and the Harz Mountains.

Our objectives were to quantify phenotypic differences in crown architecture and genetic differentiation of nSSR markers between these neighbouring populations.

We tested the following hypotheses:

(1) There is large phenotypic differentiation $\left(P_{\mathrm{ST}}\right)$ among the investigated stands.

(2) All stands show a high genetic variation, but only low genetic differentiation based on neutral SSR markers.

(3) Signatures of selection for crown types can be detected by contrasting phenotypic and genetic differentiation $\left(P_{\mathrm{ST}}>F_{\mathrm{ST}}\right)$.

Our results are discussed regarding the human influence on genetic structures and the phenotypic variation of $P$. abies.

\section{Materials and Methods}

\subsection{Study Sites and Sampling}

A total of 1325 adult trees were sampled in seven stands growing in altitudes from $770 \mathrm{~m}$ to $1060 \mathrm{~m}$ above sea level (a.s.1.). Selected stands are located in the low mountain ranges of the Thuringian Forest, the Ore Mountains (Saxony), and the Harz Mountains (Lower-Saxony/Saxony-Anhalt), all being part of the Central German Uplands (Figure S1a-d). In each region, two neighbouring Norway spruce stands were sampled-one consisting of trees with narrow crowned mountain spruce phenotypes of autochthonous origin (high elevation type, HE) and another consisting of trees with lowland phenotypes with typical broad crowns of allochthonous origin (low elevation type, LE). In each stand, terminal branches from 200 individual adult trees were collected between June and August 2016. We sampled all upper layer trees, starting from one edge of the stand, until 200 samples were collected. In addition, as a typical high elevation narrow crowned spruce stand, the relict population, "Schlossbergfichte", near Oberhof, Thuringia, was included with 75 individuals representing nearly the complete stock of old adult trees in this stand. All stands are growing under similar climatic conditions, such as mean temperature, length of the vegetation period, snow cover days, and wind speed (Table 1.) The names for low and high elevation type stands are abbreviated as LE and HE, respectively, with Thy, Sa, and $\mathrm{H}$ in the name indicating Thuringian Forest, Ore mountains (Saxony), and Harz, respectively. 
Table 1. Climatological and stand specific data.

\begin{tabular}{|c|c|c|c|c|c|c|c|c|}
\hline Stand & $\mathbf{N}$ & $\begin{array}{l}\text { Age of } \\
\text { Upper Story } \\
\text { Trees, years }\end{array}$ & $\begin{array}{c}\text { Mean Multi } \\
\text { Annual Air } \\
\text { Temperature } \\
\text { 1981-2010, } \\
{ }^{\circ} \mathrm{C}\end{array}$ & $\begin{array}{c}\text { Mean } \\
\text { Vegetation } \\
\text { Period in } \\
\text { 1992-2015, } \\
\text { days }\end{array}$ & $\begin{array}{c}\text { Mean Snow } \\
\text { Cover Days } \\
\text { in } \\
\text { 1981-2010, } \\
\text { days }\end{array}$ & $\begin{array}{c}\text { Annual } \\
\text { Mean } \\
\text { Precipitation } \\
\text { in } \\
\text { 1981-2010, } \\
\text { mm }\end{array}$ & $\begin{array}{c}\text { Mean Wind } \\
\text { in } 20 \mathrm{~m} \text { a.g.1. } \\
\mathrm{m} / \mathrm{s} \text { in } \\
1981-2000\end{array}$ & $\begin{array}{c}\text { Elevation } \\
\text { Range Of } \\
\text { Sampled } \\
\text { Individuals, } \\
\text { m a.s.l. }\end{array}$ \\
\hline LE_H & 200 & 180 & 4.7 & 181.0 & 141.5 & 1668.5 & 56 & $889-915$ \\
\hline HE_H & 250 & $300 *$ & 3.9 & 177.0 & 158.0 & 1793.0 & 79 & $1036-1065$ \\
\hline LE_S & 200 & 162 & 5.2 & 184.0 & 127.0 & 1210.0 & 55.5 & $972-1009$ \\
\hline HE_S & 200 & 142 & 4.9 & 182.0 & 136.0 & 1255.0 & 58 & 988-1014 \\
\hline LE_Thy & 200 & 90 & 5.7 & 190.0 & 122.0 & 1331.0 & 57 & 899-912 \\
\hline HE_Thy & 200 & 151 & 6.3 & 195.5 & 100.5 & 1211.0 & 39 & $761-776$ \\
\hline Schloss-bergfichte & 75 & $280 *$ & 5.8 & 191.0 & 116.0 & 1331.0 & 50 & $818-840$ \\
\hline Mean & & & 5.2 & 185.8 & 128.7 & 1399.9 & 56.4 & 921 \\
\hline
\end{tabular}

Number of sampled individuals $(\mathrm{N})$, mean air temperature, mean length of the vegetation period, mean number of days with a snow cover $>1 \mathrm{~cm}$ in the morning, mean annual precipitation, mean wind speed at $20 \mathrm{~m}$ above ground level, and the elevation range in the sampled stands. LE: Low elevation type; HE: High elevation type; S: Ore Mountains (Saxony); Thy: Thuringia; H: Harz Mountains. Values for climatological parameters were taken from extrapolated $1 \times 1 \mathrm{~km}$ grid maps of the long-term average measurements [38-43]. For individuals falling in different grids, the mean of these grid values is given and used for calculation of the total mean. The mean vegetation period is calculated from the grid values of the mean end-date minus the mean starting-date of the vegetation period (both are presented in days from New Year). Elevation data were taken from the GPS data and stand age according to information given by the forestry officials. * The age of the "Schlossbergfichte" population is based on the oldest trees [44,45], and the age of the HE_Harz population is based on the oldest trees of equivalent stands at Mt. Brocken [46].

\subsection{Phenotypic Assessment}

During the collection of needle material, visual assessment of each tree for crown architectural characteristics was carried out. The spectrum of possible trait expressions was subdivided in three categories, representing the high elevation (mountainous), intermediate, and low elevation (lowland) phenotypes (Table 2). A schematic visualisation of the traits based on a previous study [5] can be found in Figure S2. Additional crown breakage and the occurrence of forking was noted. Breakage of the main stem was noted irrespective of the number of breakage points. Forking was diagnosed when more than one secondary stem replaced the lost apical shoot.

Table 2. The assessed phenotypic traits and phenotypes associated with elevation.

\begin{tabular}{cccc}
\hline Trait & Mountainous & Phenotype & Lowland \\
\cline { 2 - 4 } $\begin{array}{c}\text { overall crown architecture; } \\
\text { structural appearance }\end{array}$ & narrow shaped crown & equivocal/intermediate shape & $\begin{array}{c}\text { Intermediate } \\
\text { angle of the first } \\
\text { order branches }\end{array}$ \\
$\begin{array}{c}\text { branching pattern of the } \\
\text { second order branches }\end{array}$ & $\begin{array}{c}\text { clearly downwards facing } \\
\text { branches, stem and branches }\end{array}$ & $\begin{array}{c}\text { no clear branch orientation up- } \\
\text { or downwards }\end{array}$ & $\begin{array}{c}\text { facing branches, all } \\
\text { angles between stem and } \\
\text { branches right or obtuse }\end{array}$ \\
\hline
\end{tabular}

The traits were scored in three categories, which were summarizations of the categories used by various authors [4,7,12,13].

\subsection{Marker Analysis}

All individuals were genotyped at 7 random genomic SSRs (gSSRs) and 4 expressed sequenced tag SSRs (EST-SSRs) (Table 3). Additional information on potential gene functions of the EST-SSRs is provided in Table 4. A total of 46 unlabelled primer pairs were tested for amplification, including SSRs developed specifically for Picea abies and SSRs adapted from other Picea species [47-54]. Further requirements for marker selection were the absence of null alleles in earlier studies $[55,56]$ and the known location in different linkage groups of P. abies $[25,57,58]$. Eleven primer pairs that generated single-locus and polymorphic products were finally selected for the population analysis. 


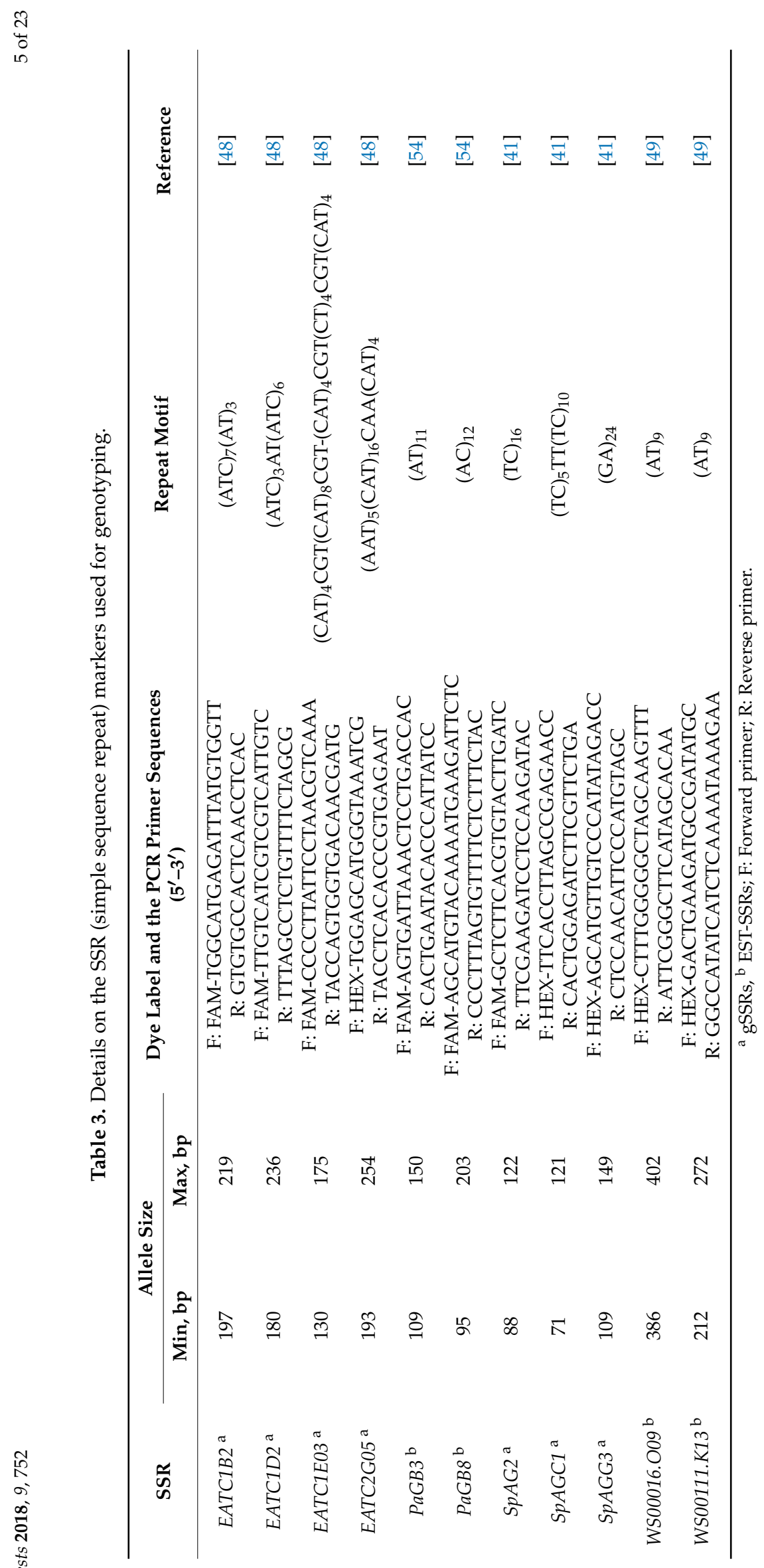


Table 4. Annotation of the four EST (expressed sequenced tag)-sequences with SSRs (EST-SSRs) used in this study $[49,54]$.

\begin{tabular}{cccc}
\hline EST-SSR & $\begin{array}{c}\text { GenBank } \\
\text { Accession } \\
\text { Number }\end{array}$ & Annotation & $\begin{array}{c}\text { Location of SSR } \\
\text { in the EST }\end{array}$ \\
\hline PaGB3 & AJ133748 & P. abies mRNA for major intrinsic protein & (aquaporin) \\
PaGB8 & AF100429 & $\begin{array}{c}\text { P. abies clone PA12H2 repetitive DNA sequence } \\
\text { NP 197764- expressed protein (A. thaliana) }\end{array}$ & $3^{\prime}$ UTR \\
$W S 00016.009 *$ & CN480894 & BAB86071-putative beta-glucosidase (O. sativa & $3^{\prime}$ UTR \\
WS00111.K13* & CN480897 & (japonica cultivar-group)) & \\
\hline
\end{tabular}

\subsection{DNA Extraction}

From each sample tree approximately $50 \mathrm{mg}$ fresh needle tissue was cut into small pieces, frozen in liquid nitrogen, and ground in a MM300 ball mill (Retsch, Haan, Germany) for $2 \mathrm{~min}$ at $30 \mathrm{~Hz}$. For the extraction of total DNA, we used the DNeasy ${ }^{\mathrm{TM}} 96$ Plant Kit (Qiagen, Hilden, Germany) according to the manufacturer's protocol with the minor modification of adding $5 \mathrm{~mL}$ of $26 \%$ polyphenylpyrovat solution to the $90.5 \mathrm{~mL}$ lysis buffer. Initial DNA concentration was measured using a NanoDrop ${ }^{\mathrm{TM}}$ 2000 spectrophotometer (Thermo Fisher Scientific, Madison, SD, USA).

All PCR reactions were performed in a $14 \mu \mathrm{L}$ total volume, containing $1 \mu \mathrm{L}$ of 1:10 diluted DNA (ca. $20 \mathrm{ng}$ ). The PCR mix contained $1 \times$ reaction buffer B (Solis BioDyne, Tartu, Estonia), $2.68 \mathrm{mM}$ $\mathrm{MgCl}_{2}, 178.57 \mu \mathrm{M}$ for each dNTP, and one unit of HOT FIREPol ${ }^{\circledR}$ (Solis BioDyne, Tartu, Estonia) Taq polymerase. Each forward and reverse primer was added in a concentration given in Table S1.

The reaction started with an initial incubation for $15 \mathrm{~min}$ at $95^{\circ} \mathrm{C}, 10$ touch-down cycles of denaturation at $94^{\circ} \mathrm{C}$, followed by annealing at $60^{\circ} \mathrm{C}\left(\Delta-1^{\circ} \mathrm{C}\right)$ and extension at $72{ }^{\circ} \mathrm{C}$ each for $1 \mathrm{~min}$, 25 cycles at $94{ }^{\circ} \mathrm{C}, 50^{\circ} \mathrm{C}$, and $72{ }^{\circ} \mathrm{C}$ with each temperature level kept for $1 \mathrm{~min}$, and final extension at $72{ }^{\circ} \mathrm{C}$ for $20 \mathrm{~min}$. All reactions were run in a Biometra TProfessional Basic thermocycler (Analytic Jena AG, Jena, Germany). SSR fragments were separated on an $\mathrm{ABI}^{\mathrm{TM}}$ 3130xl Genetic Analyzer (Applied Biosystems, Foster City, CA, USA) with the size standard GeneScan ${ }^{\mathrm{TM}} 500$ ROX $^{\mathrm{TM}}$ as a reference (Applied Biosystems, Foster City, CA, USA). Peak calling was done in the GeneMapper ${ }^{\mathrm{TM}} \mathrm{v}$ 4.1 software (Applied Biosystems, Foster City, CA, USA).

\subsection{Phenotypic Variation}

To assess differentiation and structuring of phenotypic traits and to compare the results with the genetic data, we used the $Q_{\text {ST }}$ parameter and multivariate analyses, as follows.

The commonly used genetic differentiation measure, $G_{\mathrm{ST}}$, has its analogy in $Q_{\mathrm{ST}}$ to characterize the among population genetic variance exhibited by quantitative traits [60]. In case the among population additive genetic component of variance is unknown, $Q_{\mathrm{ST}}$ can be estimated based on the phenotypic data. This estimate of phenotypic differentiation among populations $\left(P_{\mathrm{ST}}\right)$ is reliant on the scaling parameters, $c$ (the proportion of total variance explained by the additive effect) and $h^{2}$ (narrow sense heritability) [61,62]. Usually, no prior knowledge of $c / h^{2}$ exists, and since this ratio can also vary across population pairs, robustness of the estimated $P_{\mathrm{ST}}$ on this ratio should be evaluated [62]. We calculated $P_{\text {ST }}$ on the phenotypic data and evaluated its robustness with the Pstat-package (version 1.2) [63] in $R$ (version 3.5.1) [64].

In addition, we used discriminant analysis (DA) of principal components (PCs) to analyse the phenotypic dataset. In contrast to principal component analysis (PCA), where the PCs are optimised for the maximal represented total variance, DAPC (discriminate analysis of principal components) maximises the between group variance while minimizing within group variance [65]. To choose the number of retained PCs, we ran a stratified cross-validation step with 5000 replications, and the number of used discriminant functions (DFs) was fixed to 2, as these always had much higher eigenvalues (EVs) 
than the remaining DFs. Two PCs were chosen as these had the lowest mean squared error, the highest number of correctly assigned individuals of the subsample, and explained $58.1 \%$ of the variance. To test for significance of group separation, a multivariate analysis of variance (MANOVA) on the retained PCs was performed, where the independent variables, contrary to DA, are the population groups. Finally, a classical PCA and a spatial principal component analysis (sPCA) [66] that optimizes the product of the variance and the spatial autocorrelation were calculated.

\subsection{Genetic Variation—SSR Analyses}

Allele binning was done using a custom R [64] script. Histograms of raw peak size data per locus were plotted with fine scale breakpoints and the binning limits of each allele per locus were manually defined. Then, we double checked the allele sizing further, and, if necessary, corrected allele sizes to make them consistent and reliable.

The Hardy-Weinberg equilibrium (HWE) was tested using the exact test proposed by Engels [67] and implemented in the R package "HWxtest" (version 1.1.7) [68].

Linkage disequilibrium (LD) was assessed as the standardized index of association, $\bar{r}_{d}$ [69], in a pairwise loci comparison for each stand. Occurrence of significance of the LD values in each stand was evaluated by 10,000 permutations using the R package "poppr" (version 2.8.1) [70].

Null allele frequencies were estimated by the expectation maximisation (EM) algorithm [71] in the joint maximum likelihood (ML) estimation implementation in genepop [72]. Additionally, the ML method in ML-Nullfreq [73] was used. Averaging these results should improve the estimate and applying a frequency threshold of $\geq 5 \%$ for reporting can further reduce false positives [74]. Nevertheless, the occurrence of null alleles does not hinder the usage of affected markers, as conclusions drawn from assignment analyses or $F_{\mathrm{ST}}$ based estimates are unlikely to be influenced by the presence of null alleles [75].

Expected $\left(H_{\mathrm{e}}\right)$ and observed $\left(H_{\mathrm{o}}\right)$ heterozygosity, fixation index $\left(F_{\mathrm{IS}}\right)$, and its $p$-values were calculated using Arlequin 3.5.2.2 [76]. Pairwise $F_{\mathrm{ST}}$ and standardized $G^{\prime \prime}$ 's , and corresponding $p$-values based on 10,000 permutations, were calculated using GenAlEx 6.5 [77]. The mean number of alleles per locus $(A)$, the mean allelic richness based on rarefaction $\left(A_{\mathrm{r}}\right)$, and the number of private allelic states within populations were calculated using the "hierfstat" (version 0.04-22) [78] and "poppr" [70] R-packages. To test for differences in diversity between stands, regions, and between high and low elevation type stands, linear mixed models accounting for differences in diversity between loci based on the rarefied allelic richness were calculated with the R-package "Ime4" (version 1.1-18-1) [79]. The model included the rarefied allelic richness as a response variable, stand or region as a fixed effect, and locus as a random effect.

Being located in expressed genes, some EST-SSRs may reflect imprints of selection [80,81], which could be inferred from population genetic analysis when their variation and differentiation significantly deviate from those that are expected under neutrality (a so called $F_{\mathrm{ST}}$ outlier test). Hence, we checked potential deviation from neutrality for all SSRs using the $F_{\mathrm{ST}}$ outlier tests implemented in the Lositan (version 1.6) [82], Arlequin 3.5.2.2 [76] and BayeScan 2.1 [83] software. We used the recommended workflow in Lositan by first estimating the neutral $F_{\mathrm{ST}}$ value $(\sim 0.004)$ using the random gSSRs, and then rerunning the analysis, including the EST-SSRs, with the stepwise mutation model and 50,000 replications. In Arlequin, 50,000 simulations of 100 demes per group were run with the finite island model also based on $F_{\mathrm{ST}}$. The default parameters were used to run the Markov chain Monte Carlo simulations implemented in BayeScan 2.1.

Hierarchical analysis of molecular variance (AMOVA) [84] was performed in Arlequin 3.5.2.2 [76] to partition variance between regions, stands, and stand types. The hierarchical structure of the dataset was described as the region in which the stands grow, the population/stand itself, and the single individuals. Alternatively, the stand classification as an HE or LE stand was used as the highest hierarchical level to compare if this grouping explains more variation than the grouping by regions. The within and between group variance was tested for significance using 5000 permutations. 
To study the relatedness of the populations, in the light of hypothetical gene flow, we applied the approach of Sundqvist et al. [85] that projects the populations on a relative migration network. This method estimates the direction and rate of migration based on either $G_{S T}[86], D[87,88]$ or $N m_{\text {Alcala }}$ [89]. We used $G_{S T}$, as it was shown to perform best in most scenarios [78], and further tested for significant directional migration by 10,000 permutations in the "diveRsity" - R-package (version 1.9.90) [90].

To study the structuring of individuals at the SSR markers accounting for spatial autocorrelation, we used sPCA [66] that optimizes the product of the variance and the spatial autocorrelation measured by Moran's I [91,92]. Global or local structures with positive or negative autocorrelation are indicated by positive or negative EVs. To test whether global or local structures are significantly different from the null hypothesis of alleles being randomly distributed across space, the estimated distribution of the EVs via Monte Carlo (MC) sampling was used. This test has higher statistical power than the previously suggested method based on $R^{2}[66,93]$. We calculated the sPCA and the test procedure as implemented in the R-package "adegenet" (version 2.1.1) [94,95]. Spatial distribution was described by spatial weights that are directly proportional to the inverse of the geographic distance matrix. The EV-MC test for local and global structure was run $10^{3}$ times. As with the phenotypic traits we calculated the alternatives, PCA and DAPC.

Finally, to determine if the sampled individuals can be grouped into different genetic clusters $(K)$, the program, STRUCTURE (Version 2.3.4) [96], was used. Admixture proportions were estimated for $K=1$ to 12 clusters with 15 replicated iterations for each cluster run with 10,000 burn-in and 50,000 following iterations. The ancestry model considering admixed individuals was chosen. Sample location information was considered as prior knowledge for the model [97], and both the degree of admixture alpha and the parameter lambda for the distribution of allele frequencies were set to be estimated from the data. Further, the model considered allele frequencies between populations to be correlated, as the result may give more accurate estimates of admixture, produces more detailed clustering results, and gives the same results as independent models in the absence of correlation [98,99]. Averaging different runs for the same $K$ was done in CLUMPAK [100] with the default settings. The runs for each $K$ were summarised according to a similarity score. If different runs passed a certain threshold value in the comparison, they were included in the major mode, which is a summary of the majority of the runs, or in one or more minor modes depending on their similarity. Methods based on DeltaK [101], the log-likelihood probability of $K(L(K))$, and the corresponding first and second order change of $L(K)$ [96] were calculated with STRUCTURE HARVESTER (Version 0.6.94) [102] to help choose the most likely number of clusters $(K)$.

\section{Results}

\subsection{Phenotypic Differentiation between Low and High Elevation Types}

A clear difference in the phenotypic traits was found between the selected high and low elevation type stands. The overall crown shape, angle, and the branching pattern were strongly correlated (Pearson correlation 0.64-0.76), due to the dependence of the crown appearance on the angle and pattern of the branches. The relative frequencies of the traits in each stand are presented in Figure 1 (values are also provided in Table S2). In the relict stand, "Schlossbergfichte" from Thuringia, all trees expressed the high elevation type according to the assessed traits, and no crown damage and forking were detected. High elevation characteristics were also found in more than half of the observed trees $(\sim 55 \%)$ in the potential autochthonous HE-Thy stand, and no damage and forking occurred. The neighbouring low elevation type stand was predominantly comprised of lowland crown shapes $(96.5 \%)$, with all trees being damaged. In the Harz Mountains, the high elevation type stand was comprised of $37 \%$ narrow crowned individuals, but most trees showed the intermediate $(62.6 \%)$ crown shape. Varying branching patterns were also observed there, and all trees were damaged. In the neighbouring low elevation type stand, most trees had broad (68\%) or intermediate (31.5\%) crowns, 
and most of them showed crown breakage (94\%). In Saxony, the trees in the high elevation type stand were of narrow crowned $(56.5 \%)$ or intermediate $(37.5 \%)$ character, with few trees showing signs of breakage $(8.5 \%)$. Intermediate crown type $(73 \%)$ and branching pattern $(66 \%)$ were typical for the low elevation type stand in Saxony, where also only a few trees were damaged (4.5\%). Accordingly, the divergence for phenotypic traits $\left(P_{\mathrm{ST}}\right)$ showed high between group variance compared to within group variance, as the crown shape traits as well as the damage traits had $P_{\mathrm{ST}}$ values of 0.952 to 0.989 for $c / h^{2}=1$. Only a weak effect of varying ratios of $c / h^{2}$ could be noted. Even for low $c / h^{2} \geq 0.1$ ratios, the $P_{\mathrm{ST}}$ value was above or near 0.95 (forking occurrence and branching pattern with $P_{\mathrm{ST}}$ values of 0.945 and 0.936 for $c / h^{2}=0.1$, Figure S3).

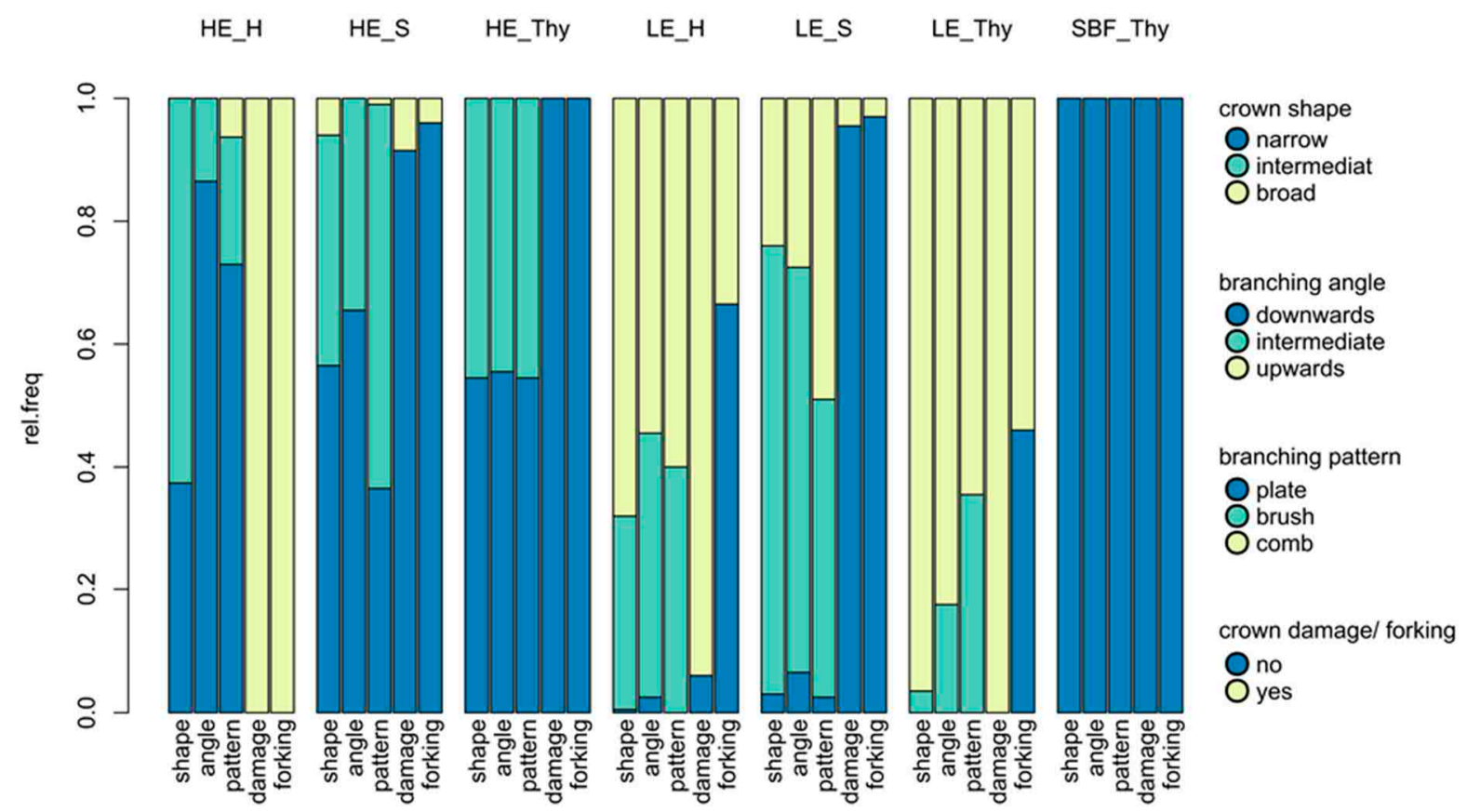

Figure 1. Relative frequencies of the assessed phenotypic traits (overall crown shape, angle of the first order branches, second order branching pattern, occurrence of crown damage, and occurrence of forking) in the studied stands. LE: Low elevation type; HE: High elevation type; SBF: relict stand "Schlossbergfichte"; S: Ore Mountains (Saxony); Thy: Thuringia; H: Harz Mountains. Categories for the traits are described in the right-hand legend.

The DAPC results demonstrated that the between group structure of the phenotypic data was mainly explained by the first two DFs as reflected in the corresponding high EVs. The low elevation type stands were separated from the high elevation type stands with the LE_S stand as a transition, as its 95\% distribution density on the first DF overlaps with all, but the SBF_Thy and HE_H distributions. The second DF mostly separated the HE_H and LE_S stands from the other stands (Figure 2). Further testing the prior group membership of the individuals by MANOVA yielded a high significance $(p \approx 0)$. Post hoc Tukey's HSD (honestly significant difference) tests of ANOVAs on each DF with Bonferroni correction showed a significant regional separation and significant differentiation between stand types. Similar phenotypic stand pairs (non-significant differences) for the first DF were SBF/HE_Thy and HE_Thy/HE_S, and SBF/HE_H, HE_Thy/HE_S and LE Thy/LE_S for the second DF. 


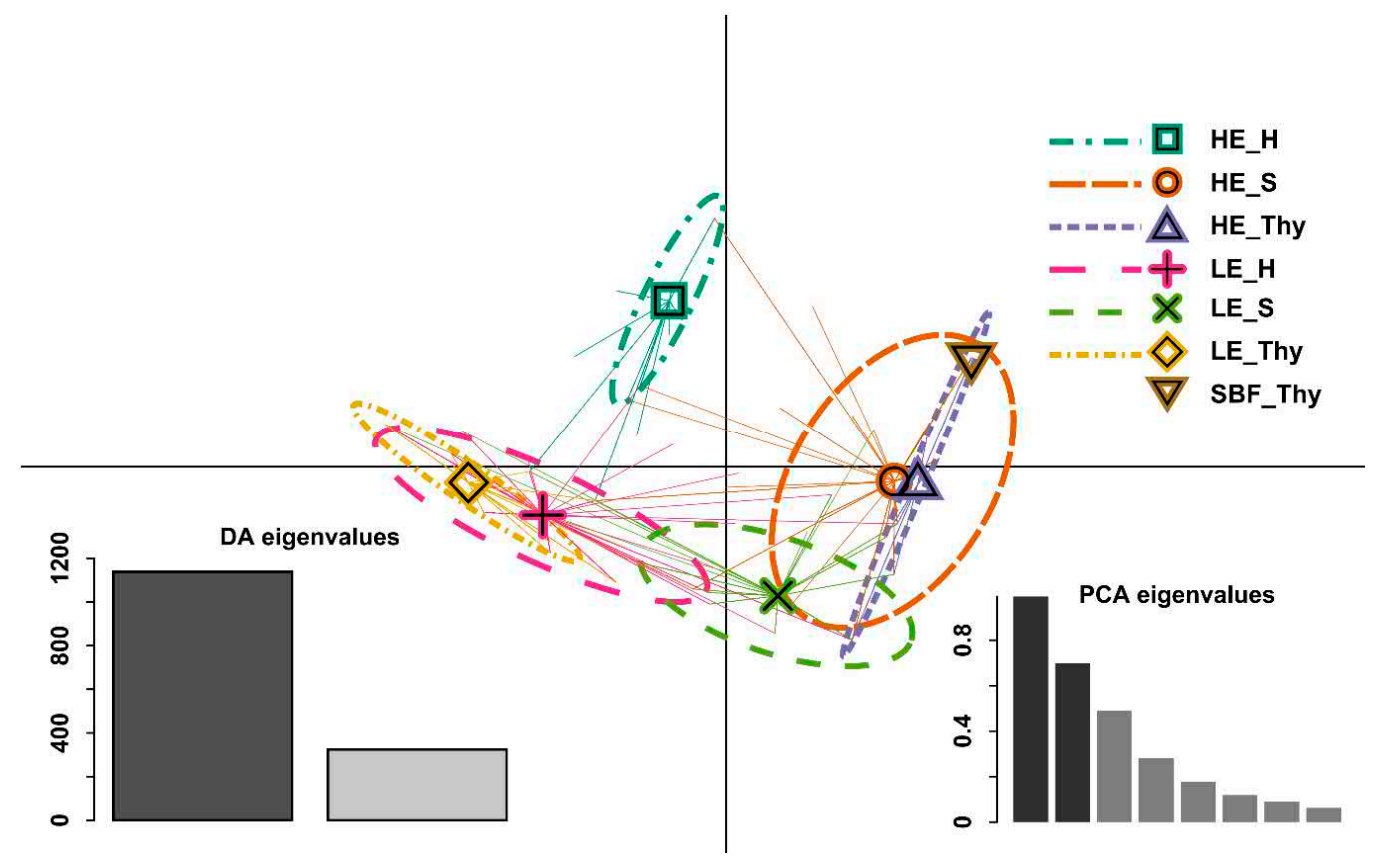

Figure 2. Discriminant analysis of principal component (DAPC) [65] on multivariate phenotypic data. Data points are displayed along the first and second discriminate axes ( $x$ - and $y$-axes, respectively) of the DAPC indicated by the stars originating from the corresponding distribution centre. Groups are depicted by $95 \%$ inertia ellipses with corresponding barycentre as a symbol. LE: Low elevation type; HE: High elevation type; SBF: relict stand "Schlossbergfichte"; S: Ore Mountains (Saxony); Thy: Thuringia; H: Harz Mountains. Note that for the stand SBF_Thy, no ellipse is displayed as all data points are identical. In the bottom left corner, the DA (discriminate analysis) eigenvalues are displayed, where the first and second DA are highlighted in dark grey and grey, respectively. The PCA (principal component analysis) eigenvalues are displayed in the lower right corner, where the retained PC's (principal component) eigenvalues are highlighted in dark grey.

PCA gave a similar data distribution on the first two axes; nevertheless, separation of the single stands was weaker compared to DAPC, as the DA step is not performed. Centres for each stand distribution were more separated in DAPC as well as the $95 \%$ inertia ellipses. In the sPCA, strong and highly significant global structure (positive autocorrelation), attributed to inter- and intra-regional separation of the stands with contrasting phenotypes, was observed. No local structure (negative autocorrelation) could be detected, which reflects the absence of clustering of similar types within the stands.

Summarizing these results, it is evident that a high phenotypic differentiation between high and low elevation type stands was observed at the assessed traits.

\subsection{Genetic Variation and Differentiation}

No significant differences in diversity between populations, regions, and stand-types could be detected based on linear mixed effect models accounting for between loci diversity divergences. In total, nine (EATC1E03 \& WS00016-O09) to 41 ( $P a G B 8(a))$ alleles per locus were observed and only small differences in $H_{\mathrm{o}}, H_{\mathrm{e}}$, and $A_{\mathrm{r}}$ values between the stands were found. The $H_{\mathrm{o}}$ values ranged from 0.630 to 0.702 , with the highest values found in the HE_Thy (0.702) and SBF_Thy (0.692) stands and lowest in the LE_H (0.640) and HE_S (0.630) stands. Values for $H_{\mathrm{e}}$ were similar among stands (0.730-0.757). The rarefied allelic richness of the relict stand, SBF_Thy, had a value (16.79) comparable to the other stands (16.13-16.83). HE_H (16.51) had a slightly reduced $A_{\mathrm{r}}$ compared to other HE stands (16.51-16.83). All, but one, $F_{\text {IS }}$ values (0.041 in LE_H) were significant, ranging from 0.079 in SBF_Thy to 0.142 in HE_H (Table 5). 
Table 5. Summary of basic population genetic parameters.

\begin{tabular}{cccccccc}
\hline Stand & $\boldsymbol{H}_{\mathbf{o}}$ & $\boldsymbol{H}_{\mathbf{e}}$ & $\boldsymbol{A}$ & $\boldsymbol{A}_{\mathbf{r}}$ & Private Alleles & $\boldsymbol{F}_{\mathbf{I S}}$ & $\boldsymbol{p}$-Value \\
\hline HE_H & 0.655 & 0.733 & 17.09 & 16.51 & 0 & 0.142 & 0.000 \\
HE_S & 0.640 & 0.751 & 16.90 & 16.83 & 2 & 0.124 & 0.000 \\
HE_Thy & 0.702 & 0.757 & 17.00 & 16.67 & 4 & 0.129 & 0.006 \\
LE_H & 0.630 & 0.730 & 16.46 & 16.13 & 4 & 0.041 & 0.099 \\
LE_S & 0.673 & 0.746 & 16.64 & 16.64 & 0 & 0.108 & 0.000 \\
LE_Thy & 0.668 & 0.734 & 16.73 & 16.46 & 5 & 0.137 & 0.000 \\
SBF_Thy & 0.692 & 0.749 & 14.55 & 16.79 & 0 & 0.079 & 0.007 \\
\hline
\end{tabular}

LE: Low elevation type; HE: High elevation type; S: Ore Mountains (Saxony); Thy: Thuringia; H: Harz Mountains; SBF: relict stand "Schlossbergfichte". $H_{\mathrm{o}}$ and $H_{\mathrm{e}}$ - expected and observed heterozygosity, respectively; $A$-mean number of alleles per locus; $A_{\mathrm{r}}$-allelic richness adjusted for different sample size by rarefaction; $F_{\mathrm{IS}}$-index of fixation with corresponding $p$-values based on permutation.

Deviation from HWE was found for five loci in several stands. Locus WS0016-O09 deviated in all stands from HWE; PaGB3 in all stands, but SBF_Thy; and EATCG05 in all stands, but LE_Thy and SBF_Thy. Furthermore, in four stands, significant deviation from HWE was found for the loci, SpAGC1 and SpAGG3, and in one or two stands for EATC1B2, EATC1E03 and SpAG2, WS0011-K13, respectively (Figure S4). The estimated null allele frequencies per locus were mostly similar in the stands, thus underestimation of genetic diversities as result of null alleles would have affected all stands equally. Loci surpassing null allele frequencies of $5 \%$ were mostly in the more complex trinucleotide repeats, namely the EATC-loci. The dinucleotide repeats expressed much lower values, which narrowly exceeded 5\% (Figure S5). Insignificant LD values $\left(\bar{r}_{d}\right)$ were found for all locus pairs based on a population-wise permutation test (Figure $\mathrm{S6}$ ). In the applied $F_{\mathrm{ST}}$ outlier tests, none of the loci exceeded the lower or upper 95\% confidence intervals of the simulation run in Lositan (Figure S7). In accordance, no directional selection was found by the Bayesian method used as well.

The high phenotypic differences between high and low elevation type populations were not reflected in genetic variation patterns at the screened supposedly selectively neutral SSRs. Overall, very low genetic differentiation was observed among populations and regions based on the 11 supposedly neutral polymorphic SSR markers. Partitioning the molecular variance indicated that variation was mostly attributed to variability of the individuals within the population $(99.60 \%$ with $90.21 \%$ within the individuals and $9.39 \%$ among individuals within the populations). Only $0.16 \%$ of the variance was attributed to among population variation within regions, and $0.24 \%$ was distributed between geographical regions. Except for the variance among regions, all levels were highly significant $(p<0.0002)$ (Table S3). When the phenotypic stand characteristics (high or low elevation type stand) were used as the highest hierarchical level no variance was partitioned between these two groups (the actual value of the percentage of variation among groups was $-0.09 \%$; negative values may arise due to the geometric distance calculation and can be considered zero).

In the pairwise comparison, low and non-significant $F_{\mathrm{ST}}$ values of 0.002 were observed between low elevation type stands in Saxony and Thuringia and in both stands in the Harz Mountains. Slightly higher values of 0.004-0.007 were detected between the relict stand, "Schlossbergfichte", and all, but the HE_Thy stand (Table S4). Comparison based on $G^{\prime \prime}$ ST gave a similar picture. Further, most of the highest $G^{\prime \prime}$ ST values (0.016-0.030) were found between the Harz Mountains and both the Thuringia and Saxony regions (Table S5). Compared to the estimated $P_{\mathrm{ST}}$ values, even for low $c / h^{2}$ ratios, all $F_{\mathrm{ST}}$ and $G^{\prime \prime}{ }_{\mathrm{ST}}$ values were much lower. Estimated rates of gene flow between stands of the same region were relatively high $(0.58-1)$, but lower between the SBF_Thy stand and the other Thuringian stands. For this stand, a high gene flow rate (0.5) was only estimated towards the HE_Thy stand. Between Saxon and Thuringian stands (also excluding SBF), high bidirectional gene flow rates were estimated. As a general pattern across all regions, a stronger gene flow from the low to the high elevation type stand was detected. Nevertheless, no significant asymmetric migration was found at $\alpha=0.05$ (Figure S8). 
We applied sPCA, which also incorporated spatial relationships among stands, to detect potential genetic structuring correlated with the geographic distances. The results revealed weak isolation by distance between the Harz Mountains and the two other regions. In Figure 3, the distribution of data along the first two sPCA-axes shows separation of the Harz population along the first axis, whereas the second axis slightly separates the HE_Thy and SBF_Thy populations from the LE_Thy population. The MC-EV test showed the absence of local structuring, but revealed highly significant global structuring $(p<0.001)$, which is attributed to the first four PCs. When only the between group variation is used, a DAPC analysis yields similar separation along the first DF as the sPCA, but a slightly stronger difference for SBF_Thy and HE_S stands. The regional differentiation was supported by MANOVA $(p<0.001)$, where the post hoc tests confirmed the regional separation of the Harz populations along the first axis. Weak geographical differentiation between Harz populations and the others was also confirmed by STRUCTURE. Evaluation of the cluster number, $K$, suggested two distinct clusters supported by delta $K$ (Figure S9a). Summarizing all runs for $K=2$ presented in Figure 4, individuals of the Harz populations formed one cluster, while individuals of all other populations were assigned to the second cluster, with a considerable amount of estimated admixture in all individuals. The analysis of the 15 runs in CLUMPAK [100] gave one major and one minor mode, which are very similar and consistent in their interpretation. Modes with a higher cluster number (especially $K \geq 6$ ) showed higher admixture proportions of one cluster each in the HE_S, HE_Thy, and SBF population (Figure S10).

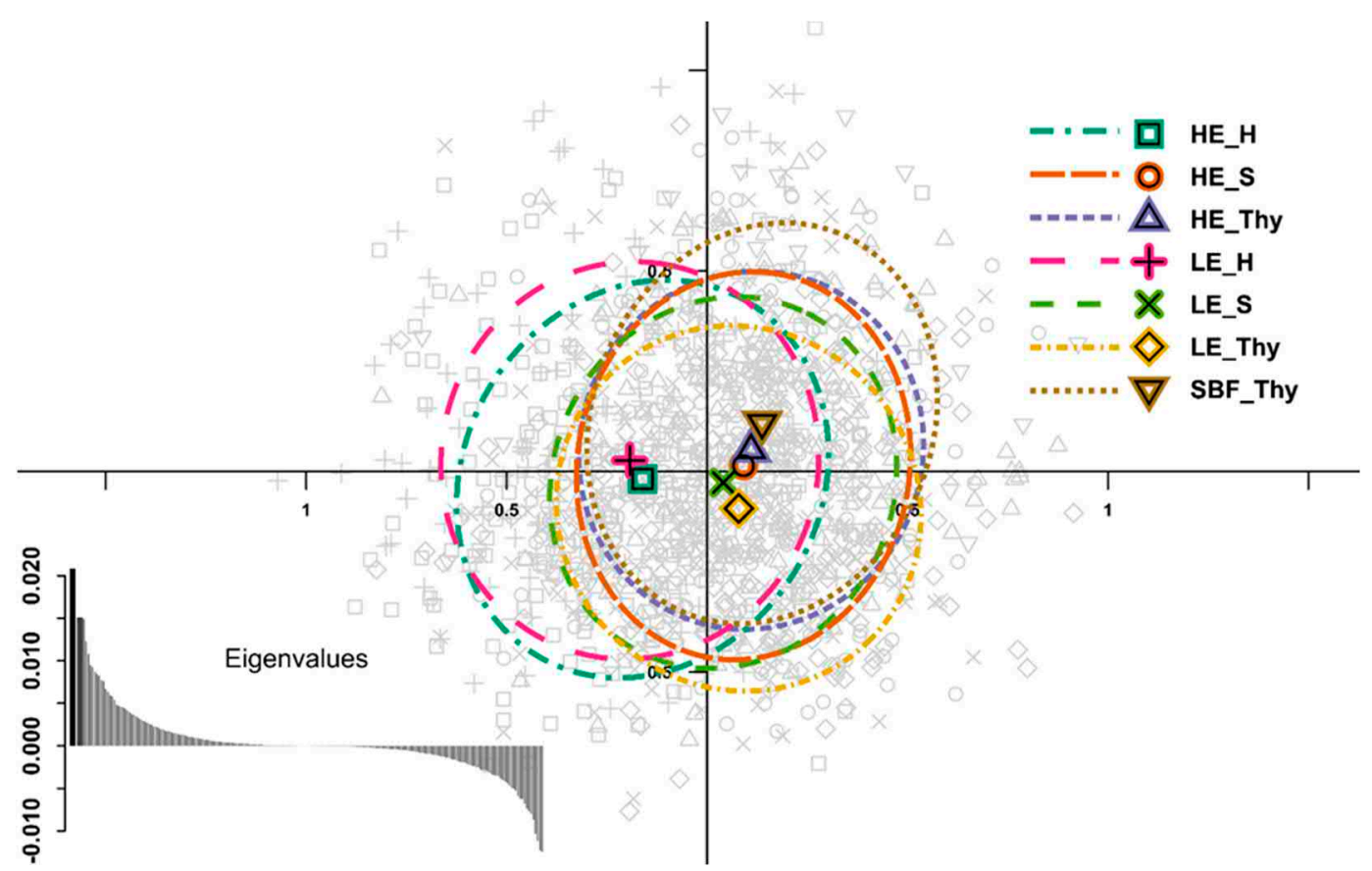

Figure 3. Spatial principal component analysis [66] based on the allele data, reflecting low spatial genetic differentiation for the SSR loci. Data points (grey) are displayed on the first and second principal components ( $x$ - and y-axes, respectively), where the symbols represent the different stands in the upper right legend. LE: Low elevation type; HE: High elevation type; SBF: relict stand "Schlossbergfichte"; S: Ore Mountains (Saxony); Thy: Thuringia; H: Harz Mountains. Groups are depicted by 95\% inertia ellipses with a corresponding barycentre as a symbol. In the bottom left corner, the eigenvalues are displayed, were the first and second eigenvalues are displayed with wider bars and highlights in the darker grey. 
a) Major mode, 8/15, Mean(Ln Prob) $=-57021.988$, Mean(similarity score $)=0.972$

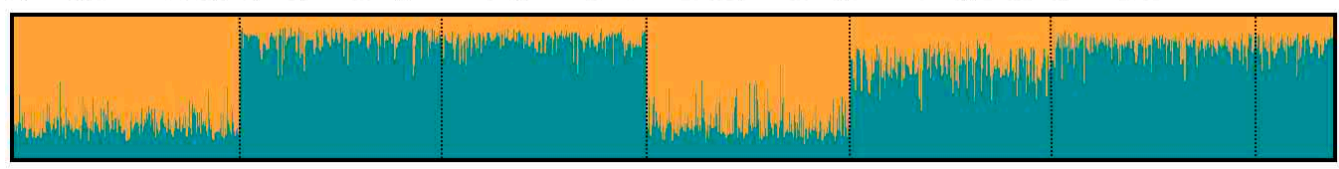

b) Minor mode, 7/15, Mean(Ln Prob) $=-56956.214$, Mean(similarity score $)=0.976$

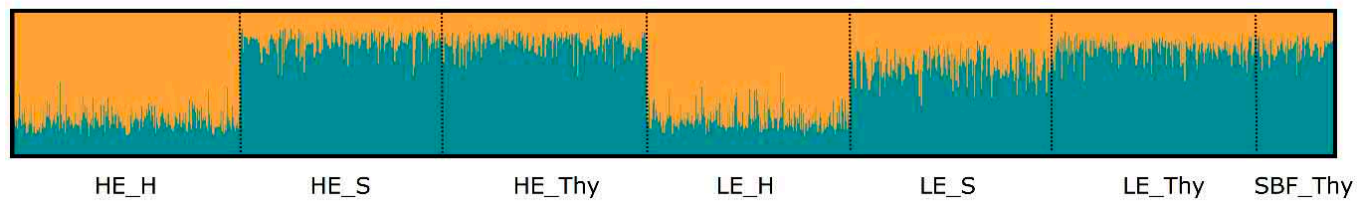

Figure 4. Clustering result based on the STRUCTURE analysis [96] and displayed as the average over the 15 runs obtained from CLUMPAK [100]. In the major mode, (a) eight of the 15 runs were summarized and an additional minor mode (b) of seven runs was obtained. The average logarithmic probability of the data for the given mode and the average similarity of the runs summarized is also given.

\section{Discussion}

Norway spruce is still one of the economically most important tree species for forestry in Europe, but the species' range is assumed to decline due to the predicted climate change [103]. Forestry in Germany also heavily relies on Norway spruce [7], but the projected future area will be more limited to the low mountain ranges [104]. Thus, the sampled locations represent important regions of today's and future spruce stands, also in terms of genetic variation of this species.

\subsection{Autochthonous and Allochthonous Stands}

Human impact strongly altered the composition of forests in Central Europe, especially in Germany [105,106], and may have had a strong impact on the neutral and adaptive genetic variation $[107,108]$. In Norway spruce, translocation and planting of non-local material started in the 18th century throughout Europe, also with the organised expansion of its natural range. In general, anthropogenic gene flow through extensive translocation of reproductive material had major effects on the genetic diversity of forest trees [8]. Hence, it is always difficult to identify autochthonous stands. In our study, we identified stands as autochthonous if there was no indication of stand establishment by artificial regeneration.

For example, in the population, "Schlossbergfichte", the autochthonous character is concluded from its stand age, where the oldest trees are now up to 285 years old [44] and can therefore be considered relatively uninfluenced by the increasing forest practice and seed trading in the 18th century [8]. In case of the high elevation type stand in the Harz Mountains (estimated age of the oldest trees between 180 and 300 years [46,109]), reports indicate no utilisation and plantation near the tree line at Mount Brocken [35]. For the other high elevation type stands in Thuringia and Saxony, their age structure and management plans indicate their autochthonous character. Indications of the allochthonous origin of low elevation types are the even aged stand structure and the visibility of planting rows. With a complete inventory of stands, we also tried to minimise random sampling effects.

\subsection{Phenotypic Differentiation}

Our comparison of stand pairs of potentially autochthonous and allochthonous spruce stands, respectively, showed a high phenotypic differentiation between stands of autochthonous and allochthonous origin. The phenotypic differentiation can be interpreted as an adaptational mechanism that is genetically controlled, but not reflected by the supposedly neutral markers used in this study. The differentiation was revealed by both the high $P_{\mathrm{ST}}$ values $(>0.9)$ and the stand separation in the DAPC analysis, with further confirmation by the significant MANOVA results. Comparison between the estimated $P_{\mathrm{ST}}$ and $F_{\mathrm{ST}}$ values at neutral loci can point to the natural selection of the phenotypical 
differences. As in the present case, with $P_{\mathrm{ST}}>F_{\mathrm{ST}}$, directional selection is likely involved in the divergence at the trait level between different populations [6]. Also, comparing standardized $G^{\prime \prime}$ ST to $P_{\mathrm{ST}}$, this observation holds true. While the discussion on which measure to use is extensive (e.g., $[87,110,111])$, it is, in the reported case, likely irrelevant which particular measure of genetic differentiation is used, because either of them was much less than $P_{S T}$. In addition, as our estimated $P_{\mathrm{ST}}$ values remained high $(>0.85)$ within the complete range of the $c / h^{2}$ ratios examined, and $P_{\mathrm{ST}}>>$ $F_{\text {ST }}$ or $G^{\prime \prime}$ ST holds, the draw conclusions can be considered as very robust [62].

Morphological differences could also be due to phenotypic plasticity and epigenetic modifications. For instance, Gruber [5] assumed that the low elevation phenotype has a relative high plasticity and could resemble the high elevation phenotype under certain conditions. For example, tree allometry and subsequent change in tree morphology can arise from environmental factors, such as competition, density, and light availability. In Norway spruce, the length of the living crown, the length of the branches, and the crown width decreases, for example, with increasing stand density [112,113]. In this study, both the allochthonous stands and the autochthonous stands are dense, grow under uniform environmental conditions, and similar silvicultural treatments were applied. In addition, allochthonous Norway spruce stands were planted with about 10,000 plants/ha, and after decades, the allochthonous stands putatively adapted to low altitude conditions, especially in Thuringia and the Harz Mountains, still show a strong phenotypic differentiation from the natural high elevation type stands.

The expected lower frequencies or absence of crown damage in narrow crowned trees were confirmed in the Thuringian and Saxony stands, but not in the high elevation type stand of the Harz Mountains. This stand is located just below the natural tree-line at Mount Brocken with around $1100 \mathrm{~m}$ a.s.l. [114] and subjected to the highest average wind speeds and the most average snow cover days in this study, which may explain that even the narrow-crowned trees may not completely withstand these harsh conditions. Concordantly, under extreme high elevation site conditions in a Swiss provenance trial, a bushy growth was observed both in high and low elevation provenances. However, high elevation provenances still showed a better growth and less damage than low elevation provenances [20], indicating different local adaptations.

Hence, our results support the assumption that Norway spruce trees of natural origin in high elevation type stands have morphologically adapted to extreme weather conditions by alteration of crown architecture $[12,13,115]$. Moreover, these results are in agreement with the hypothesis that crown morphology is at least partially genetically controlled [12], as all stands or stand pairs were subjected to similar events of snow and wind (Table 1), but still showed considerable phenotypical differences. They cannot be explained only by epigenetics because provenances adapted to low altitudinal conditions maintained their lowland crown characteristics after plantation in the high elevation environment. In stands with both high and low elevation types, trees with different crown types were randomly distributed, suggesting that micro-environmental differences within the stand have a minor effect on crown architecture. In addition, provenance trials indicated genetic differences in frost resistance and different local adaptations of low and high elevation provenances. For example, several provenance trials showed genetic differences in growth and frost tolerance between high and low elevation provenances $[19,20]$.

Environmental association studies revealed correlations of growth and frost tolerance traits and of environmental variables with genetic variation. For example, isoenzyme variation was correlated with latitudinal and elevation transects and with potentially adaptive traits (seed traits, growth, and bud burst) [116,117]. Also, SNPs in candidate genes were associated with bud set and growth cessation [118] and with environmental variables along altitudinal transects [31]. Furthermore, drought resistance [119] and susceptibility to fungal infection [120] are associated with certain SNPs.

\subsection{Genetic Variation and Differentiation}

Regarding levels of genetic variation in neighbouring low and high elevation type stands, we could not detect any differences in allelic richness or diversity. Such differences in diversity 
between natural and allochthonous stands were suggested by Gömöry [37] and Finkeldey and Ziehe [107]. Whereas, no consistent relationship of altitude and diversity between studies are reported. Comparing stands of Norway spruce growing in low elevations with high altitude stands, higher diversity was reported for the high-altitude [36,121] or intermediated populations [37], but also no correlation has been described [32], which is, correspondingly, our observation for neighboring stands of different origin.

The relatively weak genetic structure and differentiation contrasted with the morphological differentiation. However, both Harz populations, as well as the "Schlossbergfichte" population, were slightly differentiated from all other populations.

In general, as the genotyped SSR loci showed no sign of directional selection, these markers likely reflect neutral genetic variation patterns. It should, however, be noted that the relatively low number of loci used in our study could be insufficient to detect outliers. Our estimates of $F_{\mathrm{ST}}$ between the populations ranged from 0.002 to $0.007\left(G^{\prime \prime}\right.$ ST $\left.=0.002-0.030\right)$ and are comparable to the overall very low differentiation found for nSSRs on similar or even greater geographical scales, such as for Austrian $\left(F_{\mathrm{ST}}=0.0004-0.0035\right.$ [122] $)$, Swedish $\left(F_{\mathrm{ST}}=0.000-0.0206\right.$ [33]), Italian Alpine $\left(F_{\mathrm{ST}}=0.00-0.04\right.$ [123]), and Scandinavian, Baltic, and Russian populations $\left(F_{\mathrm{ST}}=0.087\right.$ [1]). These results of low differentiation among stands were mostly attributed to the high gene flow through pollen. Even between populations from putative different refugial lineages, and thus different gene pools, estimates remain low $\left(F_{\mathrm{ST}}=0.12\right.$ based on isozymes [124]; $F_{\mathrm{ST}}=0.0585$ based on EST-SSRs [125]).

However, detailed assessment based on the pairwise $F_{\mathrm{ST}}, G^{\prime \prime}{ }_{\mathrm{ST}}$, and SPCA showed a differentiation of the Harz region and the "Schlossbergfichte" population from the other populations, even though differences were small and accounted for a very small fraction of the overall variation based on the AMOVA results. From the perspective of recolonization history, the regions in focus should belong to the same lineage from the Carpathian refugium, covering both the Harz and the Bohemian Massif [30]. Nevertheless, a more recent recolonization of the Harz Mountains than for the Bohemian Massif is presumed from pollen records [24]. This could suggest a still noticeable founder effect in the Harz typical for the found pattern. Historically, the Harz Mountains were a centre of forest reproductive material export [8]. Plantations within the region are more likely to be of local origin, and thus may have retained the broad spatial structure and the genetic similarity at neutral markers between LE and HE stands. In the mode $(K=2)$ of the Bayesian clustering analysis supported by delta $K$, we found one cluster to be comprised of the Harz stands and the second cluster comprising all stands from Saxony and Thuringia. These results are in agreement with a local origin of reproductive material in the low elevation stand in the Harz Mountains. The differentiation between the Harz and the other regions may also be attributable to their geographic isolation. A similar geographic pattern was also observed for Austrian high elevation populations [122,126] and is expected for more geographically scattered populations [125].

Genetic seperation of alpine/mountainous and lowland ecotypes growing in low and highland environments were recently reported in Czech populations [127]. Similarly, autochthonous mountainous spruce stands and allochthonous stands in the Vosges Mountains were distinguishable based on RAPD markers [128]. Such differentiation was not detected in our study. For the STRUCTURE output, choosing $K$ based on delta $K$ frequently leads to the result of $K=2$ and further methods have to be considered [129] as presented in Figure S9. Based on these, a high number of $K$ could not be ruled out, especially $K=5,8$ or even 11 . Considering these modes with higher cluster numbers, a slight indication of separate ancient gene pools may be given by the admixture proportion of autochthonous populations.

Clear differentiation was, nonetheless, found between the relict population, "Schlossbergfichte", and all other populations. This population is comprised of more than 280-year-old and younger adult trees (approximately 180), which originated from natural regeneration. As seed dispersal in spruce is limited compared to pollen dispersal [130], at least the maternal part is retained within the stand. Thus, the initial genetic composition of the typical Thuringian Forest high elevation provenance may 
have been retained in this remnant population through the oldest trees, and a temporal isolation effect could be the reason for the identified small genetic divergence to the other stands. The genetic divergence of the relict population was also reflected in the migration network, as the rates towards the "Schlossbergfichte" population were, overall, lower than between other stands, and only higher migration from this stand towards the HE_Thy population was found.

While we found a genetic separation of the "Schlossbergfichte" population with clear high elevation phenotypes from all other stands, other high elevation type stands were not differentiated from low elevation types stands, suggesting high rates of gene flow between HE and LE stands. Further, high and low elevation type stands in the Saxony and Thuringia regions were not distinguishable, and at least an origin of the allochthonous stand from within these regions can be assumed. Even though no significant directional migration was found, a strong influence of pollen mediated gene flow from the majority of allochthonous stands to the natural stands can be assumed. Over generations, this process can lead to lower genetic differentiation in general and specifically to a dilution of adaptive genetic variation.

Hence, we suggest that the partially unsuited morphological characteristics in the younger autochthonous stands reflect the influence of gene flow from introduced plant material. In our study, the oldest stand, SBF_Thy, showed pure high elevation ecotypes, whereas the younger autochthonous HE stands showed higher morphological variability with a mixture of intermediate, sometimes even low, and high elevation ecotypes. Thus, our results are related to the stand age and history. The older the stands, the smaller the anthropogenic influence should be [8,33], especially in terms of translocation of material and subsequent gene flow altering the frequency of genes coding for the high elevation morphological characteristics between allochthonous and autochthonous stands. Accordingly, the trees older than 250 years in the "Schlossbergfichte" stand should represent the original genepool of the local ecotype.

\section{Conclusions}

(1) High phenotypic variation contrasting with low genetic variation measured by the nSSR markers likely reflects different local adaptations. The autochthonous high elevation type stands are locally adapted in their crown architecture to the mountainous environment, whereas the allochthonous stands are adapted to their lowland origin prior to plantation of the material. The occurrence of high elevation and low elevation crown types in neighbouring stands, and the random distribution of trees with different crown types in mixed stands suggested that crown architecture is under strong genetic control. Common garden experiments are needed to derive heritability estimates for this trait.

(2) High and low elevation type stands were not differentiated at neutral markers. Candidate gene approaches or genome scans are needed to reveal adaptive genes associated with crown architecture.

(3) A weak geographic structure was detected based on the nSSR markers. However, the Harz region and the relict population showed a weak, but significant, differentiation from the remaining stands. Gene flow by pollen and seeds likely resulted in decreased phenotypic differentiation in younger autochthonous stands, while all trees in the relict population, "Schlossbergfichte", were characterized by typical high elevation crown types.

Supplementary Materials: The following are available online at http:/ / www.mdpi.com/1999-4907/9/12/752/s1, Table S1: Concentration ( $\mathrm{ci}$ ) of each forward and reverse primer in the multiplex reactions and single-plex, Table S2: Relative frequencies of assessed morphological traits in each stand corresponding, Table S3: Hierarchical AMOVA based on the regional and population membership of the individuals, Table S4: Paiwise $F_{\mathrm{ST}}$ values between population pairs with corresponding $p$-values, Table S5: Pairwise $G^{\prime \prime}$ ST values between population pairs; Figure S1. Overview map (a) and map sections of the stand locations. Harz region (b) with the northern high elevation (HE) and southern low elevation (LE) stand. Thuringian forest (c) with the northern relict stand "Schlossbergfichte", the southern LE stand and the more eastern HE stands. Ore mountains in Saxony (d) with the western HE stand and eastern LE stand. Longitudinal and latitudinal coordinates are given on the corresponding sides of each map. Maps generated with QGIS 2.18.15 [131] using geodata from www.openstreetmaps.org [132], Figure S2: Schematic presentation of the three main crown architectural types. From left to right, lowland combe type, intermediate brush type and narrow high elevation plate type. Top secondary branching pattern as cross-sectional view and 
bottom in side view (Figures modified and reproduced with permission from J.D. Sauerländer's Verlag; Gruber, Allg. Forst-u. J.-Ztg, 160, published by J.D. Sauerländer's Verlag, 1989 [5]), Figure S3: Relationship of phenotypic divergence in a trait across populations $\left(P_{\mathrm{ST}}\right)$ [60-62] over the ratio of the total variance explained by additive genetic effects across populations and the narrow sense heritability $\left(c / h^{2}\right)$, Figure S4: Corresponding $p$-value of the log likelihood ratio test on the deviation from HWE of each locus genotyped in each population sampled. Test statistic is based on either full enumeration or Monte Carlo sampling on the count tables depended on the number of tables to be observe (for details see $[67,68]$ ), Figure S5: Estimation of the null allele frequency at each locus in each population separately. Average of maximum likelihood estimation expectation maximisation [71] in genepop [72] and ML estimation in ML-Nullfreq [73]. Dashed line indicating the estimated 5\% frequency, as it can be seen as a threshold value for reporting null alleles [74], Figure S6: Heatmaps displaying the standardizes index of association $\bar{r}_{d}[69]$ for pairwise loci comparison for each stand separately. Low values are indicated in white, whereas higher values are indicated with increasing grey shades, Figure S7: Detection of outlier loci in LOSITAN [82] exploring the relationship between $F_{\mathrm{ST}}$ and $H_{\mathrm{e}}$ among populations by permutations. Black dashed lines indicate the upper $95 \%$ confidence limit, also highlighted by fine red hatching. Black dotted lines indicate the lower $95 \%$ confidence limit, highlighted by rougher yellow hatching, Figure S8: Directional relative migration network [85] based on $G_{S T}[86]$ of potential allochthones and autochthones populations. The relative positions of the populations indicate relatedness from the perspective of hypothetical gene flow. Numbers and arrows indicate the direction and extent of gene flow (also underlined by arrow shading/thickness), Figure S9: Detection of the number of clusters K according to (a) DeltaK [101], the (b) log-likelihood probability of $K(L(K))$ and the corresponding (c) first and $(d)$ second order change of $L(K)$ [96] calculated in STRUCTURE HARVESTER [102], Figure S10: Major modes of cluster results from $K 2$ to 12 of STRUCTURE [96] analysis summarised in CLUMPAK [90]. For each $K$ the major mode is given indication the number of runs and der mean similarity of the summarisation output as well as the mean ln probability of the mode. Individuals ordered by population membership as indicated at the bottom.

Author Contributions: Conceptualization: O.C., M.M, B.V., K.K., K.V.K., O.G. and L.L.; Methodology: O.C., M.M., B.V., O.G. and L.L.; Software: O.C.; Validation: O.C., M.M, B.V., K.V.K., O.G. and L.L.; Formal Analysis: O.C.; Investigation: O.C.; Resources, K.K. and A.M.H.; Data Curation: O.C.; Writing-Original Draft Preparation: O.C.; Writing-Review \& Editing: O.C., M.M, B.V., A.M.H., K.K., K.V.K., O.G. and L.L.; Visualization: O.C.; Supervision: O.G. and L.L.; Project Administration: O.G. and L.L.; Funding Acquisition: M.M., B.V., O.G. and L.L. (listed based on position in author list).

Funding: This research was funded by the German Federal Ministry of Food and Agriculture (BMEL) represented by the Fachagentur Nachwachsende Rohstoffe e. V. (FNR) grant number FKZ 22023814. The APC was funded by the Open Access Grant Program of the German Research Foundation (DFG) and the Open Access Publication Fund of the University of Göttingen.

Acknowledgments: The authors thank the Northwest German Forest Research Institute (NW-FVA) for providing the samples of the Brocken (Harz) population with special thanks to Serge Havel for preparation of the samples, Alexandra Dolynska, Christine Radler for assistance with lab work, Staatsbetrieb Sachsenforst, ThüringenForst, Niedersächsische Landesforsten and Forstliches Forschungs- und Kompetenzzentrum (FFK Gotha) for their assistance in stand selection. We also acknowledge four anonymous reviewers for their comments that considerably improved the manuscript.

Conflicts of Interest: The authors declare no conflict of interest. The funding sponsors had no role in the design of the study; in the collection, analyses, or interpretation of data; in the writing of the manuscript, and in the decision to publish the results.

\section{References}

1. Tollefsrud, M.M.; Sønstebø, J.H.; Brochmann, C.; Johnsen, Ø.; Skrøppa, T.; Vendramin, G.G. Combined analysis of nuclear and mitochondrial markers provide new insight into the genetic structure of North European Picea abies. Heredity 2009, 102, 549-562. [CrossRef] [PubMed]

2. Heuertz, M.; De Paoli, E.; Källman, T.; Larsson, H.; Jurman, I.; Morgante, M.; Lascoux, M.; Gyllenstrand, N. Multilocus patterns of nucleotide diversity, linkage disequilibrium and demographic history of Norway spruce (Picea abies (L.) Karst.). Genetics 2006, 174, 2095-2105. [CrossRef] [PubMed]

3. Schmidt-Vogt, H. Studien zu morphologischen Variabilität der Fichte (Picea abies (L.) Karst.). Allg. Forst- $u$. J.-Ztg 1972, 142, 133-144.

4. Priehäusser, G. Die Fichten-Variationen und -Kombinationen des Bayr. Waldes nach phänotypischen Merkmalen mit Bestimmungsschlüssel. Forstwiss. Cent. 1958, 77, 151-171. [CrossRef]

5. Gruber, F. Phänotypen der Fichte (Picea abies (L.) Karst.) I. Verzweigungsphänotypen: Genotyp und Modifikation. Allg. Forst-u. J.-Ztg 1989, 160, 157-165.

6. Merilä, J.; Crnokrak, P. Comparison of genetic differentaition at marker loci and quantitative traits. J. Evol. Biol. 2001, 14, 892-903. [CrossRef] 
7. Schmidt-Vogt, H. Taxonomie, verbreitung, morphologie, ökologie, waldgesellschaften. In Die Fichte-Ein Handbuch in Zwei Bänden; Parey: Hamburg, Berlin, Germany, 1977; p. 647.

8. Jansen, S.; Konrad, H.; Geburek, T. The extent of historic translocation of Norway spruce forest reproductive material in Europe. Ann. For. Sci. 2017, 74, 56. [CrossRef]

9. Beckstein, J.M. Forstbotanik oder vollständige Naturgeschichte der deutschen Holzgewächse und einiger Fremden: Zur Selbstbelehrung für Oberförster, Förster und Forstgehülfen; Henning: Gotha, Germany, 1810.

10. Wahlenberg, G. Flora Lapponica. Available online: https://www.biodiversitylibrary.org/item/91422 (accessed on 23 May 2018).

11. Nykänen, M.L.; Peltola, H.; Quine, C.; Kellomäki, S.; Broadgate, M. Factors affecting snow damage of trees with particular reference to European conditions. Silv. Fenn. 1997, 31, 193-213. [CrossRef]

12. Gruber, F. Verzweigungssystem, Benadelung und Nadelfall der Fichte (Picea abies); Ecomed-Verlag: Landsberg am Lech, Germany, 1993.

13. Geburek, T.; Robitschek, K.; Milasowszky, N. A tree of many faces: Why are there different crown types in Norway spruce (Picea abies (L.) Karst.)? Flora Morphol. Distrib. Funct. Ecol. Plants 2008, 203, 126-133. [CrossRef]

14. König, A. Growth and snowbreak damage of Norway spruce provenances from Poland under harsh site conditions. In Forest Tree Breeding in an Ecologically Oriented Forest Management System; Meier-Dinkel, A., Steiner, W., Eds.; Schriften Forstlichen Fakultät Universität Göttingen und der Niedersächsischen Forstlichen Versuchsanstalt: Frankfurt am Main, Germany, 2002; pp. 139-150.

15. Mátyás, C. Population, conservation and ecological genetics. In Encyclopedia of Forest Sciences; Burley, J., Evans, J., Youngquist, J.A., Eds.; Elsevier: Amsterdam, The Netherlands, 2004; pp. 188-197.

16. Kathke, S.; Bruelheide, H. Differences in frost hardiness of two Norway spruce morphotypes growing at Mt. Brocken, Germany. Flora Morphol. Distrib. Funct. Ecol. Plants 2011, 206, 120-126. [CrossRef]

17. Sylvén, N. Studier Öfver Granens Formrikedom, Särskildt Dess Förgreningstyper Och Deras Skogliga Värde; Statens Skogsförsöksanstalt: Stockholm, Sweden, 1909.

18. Kiellander, C.L. Picea, Abies, Pseudozuga. In Manual of Plant Breeding VI-Breeding of Legumes and Fruits, Viniculture and Silviculture; Kappert, H., Rudorf, W., Eds.; Parey: Berlin, Hamburg, Germany, 1962; pp. 854-873.

19. Liesebach, M.; Rau, H.; König, A.O. Fichtenherkunftsversuch von 1962 und IUFRO-Fichtenherkunftsversuch von 1972-Ergebnisse von mehr als 30-Jähriger Beobachtung in Deutschland; Nordwestdeutsche Forstliche Versuchsanstalt (NW-FVA): Göttingen, Germany, 2010.

20. Kalela, A. Zur Synthese er Experimentellen Untersuchungen über Klimarassen der Holzarten; Communications Instituti Forestalis Fenniae: Helsinki, Finland, 1937.

21. Pulkkinen, P.; Pöykkö, T. Inherited narrow crown form, harvest index and stem biomass production in Norway spruce, Picea abies. Tree Physiol. 1990, 6, 381-391. [CrossRef] [PubMed]

22. Lehner, A.; Campbell, M.A.; Wheeler, N.C.; Piöykkiö, T.; Gliissl, J.; Kreike, J.; Neale, D.B. Identification of a RAPD marker linked to the pendula gene in Norway spruce (Picea abies (L.) Karst. f. pendula). Theor. Appl. Genet. 1995, 91, 1092-1094. [CrossRef] [PubMed]

23. Latałowa, M.; van der Knaap, W.O. Late quaternary expansion of Norway spruce (Picea abies (L.) Karst.) in Europe according to pollen data. Quat. Sci. Rev. 2006, 25, 2780-2805. [CrossRef]

24. Terhürne-Berson, R. Changing Distribution Patterns of Selected Conifers in the Quaternary of Europe Caused by Climatic Variations. Ph.D. Thesis, Friedrich-Wilhelms-Universität, Bonn, Germany, 16 June 2005.

25. Acheré, V.; Favre, J.M.; Besnard, G.; Jeandroz, S. Genomic organization of molecular differentiation in Norway spruce (Picea abies). Mol. Ecol. 2005, 14, 3191-3201. [CrossRef] [PubMed]

26. Vendramin, G.G.; Anzidei, M.; Madaghiele, A.; Sperisen, C.; Bucci, G. Chloroplast microsatellite analysis reveals the presence of population subdivision in Norway spruce (Picea abies K.). Genome 2000, 43, 68-78. [CrossRef] [PubMed]

27. Sperisen, C.; Büchler, U.; Gugerli, F.; Mátyás, G.; Geburek, T.; Vendramin, G.G. Tandem repeats in plant mitochondrial genomes: Application to the analysis of population differentiation in the conifer Norway spruce. Mol. Ecol. 2001, 10, 257-263. [CrossRef]

28. Gugerli, F.; Sperisen, C.; Magni, F. Haplotype variation in a mitochondrial tandem repeat of Norway spruce (Picea abies) populations suggests a serious founder effect during postglacial re-colonization of the western Alps. Mol. Ecol. 2001, 1255-1263. [CrossRef] 
29. Scalfi, M.; Mosca, E.; Di Pierro, E.A.; Troggio, M.; Vendramin, G.G.; Sperisen, C.; La Porta, N.; Neale, D.B. Micro-and macro-geographic scale effect on the molecular imprint of selection and adaptation in Norway spruce. PLoS ONE 2014, 9, e115499. [CrossRef]

30. Tollefsrud, M.M.; Kissling, R.; Gugerli, F.; Johnsen, Ø.; Skrøppa, T.; Cheddadi, R.; Van Der Knaap, W.O.; Latałowa, M.; Terhürne-Berson, R.; Litt, T.; et al. Genetic consequences of glacial survival and postglacial colonization in Norway spruce: Combined analysis of mitochondrial DNA and fossil pollen. Mol. Ecol. 2008, 17, 4134-4150. [CrossRef]

31. Di Pierro, E.A.; Mosca, E.; González-Martínez, S.C.; Binelli, G.; Neale, D.B.; La Porta, N. Adaptive variation in natural Alpine populations of Norway spruce (Picea abies (L.) Karst.) at regional scale: Landscape features and altitudinal gradient effects. For. Ecol. Manag. 2017, 405, 350-359. [CrossRef]

32. Müller-Starck, G. Genetic variation in high elevated populations of Norway spruce (Picea abies (L.) Karst.) in Switzerland. Silv. Genet. 1995, 44, 356-362.

33. Ndrosiuk, B.P.A.; Shimono, A.; Westin, J.; Lindgren, D.; Fries, A.; Wang, X. Genetic status of Norway spruce (Picea abies) breeding populations for northern Sweden. Silvae Genet. 2013, 63, 288-295. [CrossRef]

34. Quack, M. Molekulargenetische Untersuchungen zur Variabilität der Fichte (Picea abies (L.) Karst.) in Deutschland. Ph.D. Thesis, Universität Trier, Trier, Germany, 28 April 2004.

35. Greger, O. Erfassung von Relikten des Autochtonen Fichtenvorkommens im Hochharz. Ph.D. Thesis, Georg-August-Universität, Göttingen, Germany, 1992.

36. Maghuly, F.; Pinsker, W.; Praznik, W.; Fluch, S. Genetic diversity in managed subpopulations of Norway spruce (Picea abies (L.) Karst.). For. Ecol. Manag. 2006, 222, 266-271. [CrossRef]

37. Gömöry, D. Effect of stand origin on the genetic diversity of Norway spruce (Picea abies Karst.) populations. For. Ecol. Manag. 1992, 54, 215-223. [CrossRef]

38. Deutscher Wetterdienst DWD Climate Data Center (CDC): Multi-Annual Means of Grids of Monthly Averaged Daily Mean Air Temperature (2m) over Germany, Version v1.0, Offenbach. 2017. Available online: ftp:/ /ftp-cdc.dwd.de/pub/CDC/grids_germany/multi_annual/air_temperature_mean/8110/ (accessed on 2 November 2017).

39. Deutscher Wetterdienst DWD Climate Data Center (CDC): Multi-Annual Grids of the Begin of the Vegetation Period in Germany, Version 0.x, Offenbach. 2017. Available online: ftp:/ /ftp-cdc.dwd.de/pub/CDC/grids_ germany/multi_annual/vegetation_begin/ (accessed on 2 November 2017).

40. Deutscher Wetterdienst DWD Climate Data Center (CDC): Multi-Annual Grids of the End of the Vegetation Period in Germany, Version 0.x, Offenbach. 2017. Available online: ftp:/ /ftp-cdc.dwd.de/pub/CDC/grids_ germany/multi_annual/vegetation_end/ (accessed on 2 November 2017).

41. Deutscher Wetterdienst DWD Climate Data Center (CDC): Multi-Annual Grids of Numbers of Snowcover Days over Germany, Version v1.0, Offenbach. 2017. Available online: ftp://ftp-cdc.dwd.de/pub/CDC / grids_germany/multi_annual/snowcover_days / (accessed on 2 November 2017).

42. Deutscher Wetterdienst DWD Climate Data Center (CDC): Multi-Annual Grids of Precipitation Height over Germany 1981-2010, Version v1.0, Offenbach. 2017. Available online: ftp://ftp-cdc.dwd.de/pub/CDC/ grids_germany/multi_annual/precipitation/8110/ (accessed on 2 November 2017).

43. Deutscher Wetterdienst DWD Climate Data Center (CDC): $1 \mathrm{~km} \times 1 \mathrm{~km}$ Gridded Mean of Annual Wind Speeds from $10 \mathrm{~m}$ to $100 \mathrm{~m}$ (in $10 \mathrm{~m}$ Steps) above Ground and Weibull Parameters, for Germany, Version V0.1, Offenbach. 2014. Available online: ftp:/ /ftp-cdc.dwd.de/pub/CDC/grids_germany/wind_parameters / resol_1000x1000/ (accessed on 2 November 2017).

44. Wilhelm, B. Die autochtonen Höhenfichten des Thüringer Waldes am Beispiel der Oberhofer Schlosßberg-Fichte. AFZ 1990, 33, 845-846.

45. Jetschke, G. Oberhofer Schlossberg-Fichten und Methusalem-Kiefern von Paulinzella: Zwei Bemerkenswerte Altbestände von Nadelbäumen; ThüringenForst—Anstalt öffentlichen Rechts: Erfurt, Germany, 2019; (accepted); Mitteilungen 37/2019.

46. Meyer, P.; Janda, P.; Mikoláš, M.; Trotsiuk, V.; Krumm, F.; Mrhalová, H.; Synek, M.; Lábusová, J.; Kraus, D.; Brandes, J.; et al. A matter of time: Self-regulated tree regeneration in a natural Norway spruce (Picea abies) forest at Mt. Brocken, Germany. Eur. J. For. Res. 2017, 136, 907-921. [CrossRef]

47. Scotti, I.; Paglia, G.P.; Magni, F.; Morgante, M. Efficient development of dinucleotide microsatellite markers in Norway spruce (Picea abies Karst.) through dot-blot selection. Theor. Appl. Genet. 2002, 104, 1035-1041. [CrossRef] 
48. Scotti, I.; Magni, F.; Paglia, G.P.; Morgante, M. Trinucleotide microsatellites in Norway spruce (Picea abies): Their features and the development of molecular markers. Theor. Appl. Genet. 2002, 106, 40-50. [CrossRef]

49. Rungis, D.; Bérubé, Y.; Zhang, J.; Ralph, S.; Ritland, C.E.; Ellis, B.E.; Douglas, C.; Bohlmann, J.; Ritland, K. Robust simple sequence repeat markers for spruce (Picea spp.) from expressed sequence tags. Theor. Appl. Genet. 2004, 109, 1283-1294. [CrossRef]

50. Shi, Y.-Z.; Forneris, N.; Rajora, O.P. Highly informative single-copy nuclear microsatellite DNA markers developed using an AFLP-SSR approach in black spruce (Picea mariana) and red spruce (P. rubens). PLoS ONE 2014, 9. [CrossRef]

51. Pfeiffer, A.; Olivieri, A.M.; Morgante, M. Identification and characterization of microsatellites in Norway spruce (Picea abies K.). Genome 1997, 40, 411-419. [CrossRef] [PubMed]

52. Fluch, S.; Burg, A.; Kopecky, D.; Homolka, A.; Spiess, N.; Vendramin, G.G. Characterization of variable EST SSR markers for Norway spruce (Picea abies L.). BMC Res. Notes 2011, 4, 401. [CrossRef] [PubMed]

53. Hodgetts, R.B.; Aleksiuk, M.A.; Brown, A.; Clarke, C.; Macdonald, E.; Nadeem, S.; Khasa, D.; Macdonald, E. Development of microsatellite markers for white spruce (Picea glauca) and related species. Theor. Appl. Genet. 2001, 102, 1252-1258. [CrossRef]

54. Besnard, G.; Acheré, V.; Rampant, P.F.; Favre, J.M.; Jeandroz, S. A set of cross-species amplifying microsatellite markers developed from DNA sequence databanks in Picea (Pinaceae). Mol. Ecol. Resour. 2003, 3, 380-383. [CrossRef]

55. De Sousa, S.N.; Finkeldey, R.; Gailing, O. Commentary: Experimental verification of microsatellite null alleles in norway spruce (Picea abies (L.) Karst.): Implications for population genetic studies. Plant Mol. Biol. Rep. 2005, 23, 113-119. [CrossRef]

56. Yazdani, R.; Scotti, I.; Jansson, G.; Plomion, C.; Mathur, G. Inheritance and diversity of simple sequence repeat (SSR) microsatellite markers in various families of Picea abies. Hereditas 2003, 138, 219-227. [CrossRef] [PubMed]

57. Paglia, G.P.; Olivieri, A.M.; Morgante, M. Towards second-generation STS (sequence-tagged sites) linkage maps in conifers: A genetic map of Norway spruce (Picea abies K.). Mol. Gen. Genet. 1998, 258, 466-478. [CrossRef]

58. Scotti, I.; Burelli, A.; Cattonaro, F.; Chagné, D.; Fuller, J.; Hedley, P.E.; Jansson, G.; Lalanne, C.; Madur, D.; Neale, D. Analysis of the distribution of marker classes in a genetic linkage map: A case study in Norway spruce (Picea abies Karst). Tree Genet. Genomes 2005, 1, 93-102. [CrossRef]

59. Altschul, S.F.; Madden, T.L.; Schäffer, A.A.; Zhang, J.; Zhang, Z.; Miller, W.; Lipman, D.J. Gapped BLAST and PSI-BLAST: A new generation of protein database search programs. Nucleic Acid. Res. 1997, 25, 3389-3402. [CrossRef]

60. Spitze, K. Population structure in Daphnia obtusa: Quantitative genetic and allozymic variation. Genetics 1993, 135, 367-374. [CrossRef]

61. Leinonen, T.; McCairns, R.J.S.; O'Hara, R.B.; Merilä, J. QST-FST comparisons: Evolutionary and ecological insights from genomic heterogeneity. Nat. Rev. Genet. 2013, 14, 179-190. [CrossRef] [PubMed]

62. Brommer, J.E. Whither $P_{\mathrm{ST}}$ ? The approximation of $Q_{\mathrm{ST}}$ by $P_{\mathrm{ST}}$ in evolutionary and conservation biology. J. Evol. Biol. 2011, 24, 1160-1168. [CrossRef] [PubMed]

63. Da Silva, S.B.; Da Silva, A. Pstat: An R Package to Assess Population Differentiation in Phenotypic Traits. $R$ J. 2018, 10, 447-454.

64. R Core Team. R: A Language and Environment for Statistical Computing 2018. Available online: https: / / www.R-project.org (accessed on 2 November 2018).

65. Jombart, T.; Devillard, S.; Balloux, F. Discriminant analysis of principal components: A new method for the analysis of genetically structured populations. BMC Genet. 2010. [CrossRef] [PubMed]

66. Jombart, T.; Devillard, S.; Dufour, A.; Pontier, D. Revealing cryptic spatial patterns in genetic variability by a new multivariate method. Heredity 2008, 101, 92-103. [CrossRef] [PubMed]

67. Engels, W.R. Exact tests for Hardy-Weinberg proportions. Genetics 2009, 183, 1431-1441. [CrossRef]

68. Engels, W.R. HWxtest: Exact Tests for Hardy-Weinberg Proportions. R package version 1.1.7 2016. Available online: https: / /CRAN.R-project.org/package=HWxtest (accessed on 2 November 2018).

69. Agapow, P.-M.; Burt, A. Indices of multilocus linkage disequilibrium. Mol. Ecol. Notes 2001, 1, 101-102. [CrossRef] 
70. Kamvar, Z.N.; Tabima, J.F.; Grünwald, N.J. Poppr: An R package for genetic analysis of populations with clonal, partially clonal, and/or sexual reproduction. PeerJ 2014. [CrossRef]

71. Dempster, A.P.; Laird, N.M.; Rubin, D.B. Maximum likelihood from incomplete data via the EM algorithm. J. R. Stat. Soc. 1977, 39, 1-38.

72. Rousset, F. GENEPOP'007: A complete re-implementation of the GENEPOP software for Windows and Linux. Mol. Ecol. Resour. 2008, 8, 103-106. [CrossRef]

73. Kalinowski, S.T.; Taper, M.L. Maximum likelihood estimation of the frequency of null alleles at microsatellite loci. Conserv. Genet. 2006, 7, 991-995. [CrossRef]

74. Dabrowski, M.J.; Bornelöv, S.; Kruczyk, M.; Baltzer, N.; Komorowski, J. “True" null allele detection in microsatellite loci: A comparison of methods, assessment of difficulties and survey of possible improvements. Mol. Ecol. Resour. 2015, 15, 477-488. [CrossRef] [PubMed]

75. Carlsson, J. Effects of microsatellite null alleles on assignment testing. J. Hered. 2008, 99, 616-623. [CrossRef] [PubMed]

76. Excoffier, L.; Lischer, H.E.L. Arlequin suite ver 3.5: A new series of programs to perform population genetics analyses under Linux and Windows. Mol. Ecol. Resour. 2010, 10, 564-567. [CrossRef] [PubMed]

77. Peakall, R.; Smouse, P.E. GenALEx 6.5: Genetic analysis in Excel-Population genetic software for teaching and research-an update. Bioinformatics 2012, 28, 2537-2539. [CrossRef] [PubMed]

78. Goudet, J.; Jombart, T. Hierfstat: Estimation and Tests of Hierarchical F-Statistics. R package version 0.04-22. 2015. Available online: https:/ / CRAN.R-project.org/package=hierfstat (accessed on 2 November 2018).

79. Bates, D.; Mächler, M.; Bolker, B.; Walker, S. Fitting linear mixed-effects models using lme4. J. Stat. Softw. 2015, 67, 1-48. [CrossRef]

80. Ellis, J.R.; Burke, J.M. EST-SSRs as a resource for population genetic analyses. Heredity 2007, 99, 125-132. [CrossRef] [PubMed]

81. Kalia, R.K.; Rai, M.K.; Kalia, S.; Singh, R.; Dhawan, A.K. Microsatellite markers: An overview of the recent progress in plants. Euphytica 2011, 177, 309-334. [CrossRef]

82. Antao, T.; Lopes, A.; Lopes, R.J.; Beja-Pereira, A.; Luikart, G. LOSITAN: A workbench to detect molecular adaptation based on a Fst-outlier method. BMC Bioinform. 2008, 9, 323. [CrossRef]

83. Foll, M.; Gaggiotti, O. A genome-scan method to identify selected loci appropriate for both dominant and codominant markers: A Bayesian perspective. Genetics 2008, 180, 977-993. [CrossRef]

84. Excoffier, L.; Smouse, P.E.; Quattro, J.M. Analysis of molecular variance inferred from metric distances among DNA haplotypes: Application to human mitochondrial DNA restriction data. Genetics 1992, 131, 479-491. [CrossRef]

85. Sundqvist, L.; Keenan, K.; Zackrisson, M.; Prodöhl, P.; Kleinhans, D. Directional genetic differentiation and relative migration. Ecol. Evol. 2016, 6, 3461-3475. [CrossRef] [PubMed]

86. Nei, M. Analysis of gene diversity in subdivided populations. Proc. Natl. Acad. Sci. USA 1973, 70, 3321-3323. [CrossRef]

87. Jost, L. G ST $_{\text {Th }}$ and relatives do not measure differentiation. Mol. Ecol. 2008, 17, 4015-4026. [CrossRef]

88. Crawford, N.G. Smogd: Software for the measurement of genetic diversity. Mol. Ecol. Resour. 2010, 10, 556-557. [CrossRef] [PubMed]

89. Alcala, N.; Goudet, J.; Vuilleumier, S. On the transition of genetic differentiation from isolation to panmixia: What we can learn from $G_{\mathrm{ST}}$ and D. Theor. Popul. Biol. 2014, 93, 75-84. [CrossRef]

90. Keenan, K.; McGinnity, P.; Cross, T.F.; Crozier, W.W.; Prodöhl, P.A. diveRsity: An R package for the estimation of population genetics parameters and their associated errors. Method. Ecol. Evol. 2013, 4, 782-788. [CrossRef]

91. Moran, P.A. The interpretation of statistical maps. J. R. Stat. Soc. 1948, 10, 243-251. [CrossRef]

92. Moran, P.A. Notes on continuous stochastic phenomena. Biometrika 1950, 37, 17-23. [CrossRef] [PubMed]

93. Montano, V.; Jombart, T. An Eigenvalue test for spatial principal component analysis. BMC Bioinform. 2017. [CrossRef] [PubMed]

94. Jombart, T. Adegenet: A R package for the multivariate analysis of genetic markers. BMC Bioinform. 2008, 24, 1403-1405. [CrossRef] [PubMed]

95. Jombart, T.; Ahmed, I. Adegenet 1.3-1: New tools for the analysis of genome-wide SNP data. BMC Bioinform. 2011, 27, 3070-3071. [CrossRef] [PubMed]

96. Pritchard, J.K.; Stephens, M.; Donnelly, P. Inference of population structure using multilocus genotype data. Genetics 2000, 155, 945-959. [CrossRef] [PubMed] 
97. Hubisz, M.J.; Falush, D.; Stephens, M.; Pritchard, J.K. Inferring weak population structure with the assistance of sample group information. Mol. Ecol. Resour. 2009, 9, 1322-1332. [CrossRef]

98. Falush, D.; Stephens, M.; Pritchard, J.K. Inference of population structure using multilocus genotype data: Linked loci and correlated allele frequencies. Genetics 2003, 164, 1567-1587. [CrossRef] [PubMed]

99. Porras-Hurtado, L.; Ruiz, Y.; Santos, C.; Phillips, C.; Carracedo, Á.; Lareu, M.V. An overview of STRUCTURE: Applications, parameter settings, and supporting software. Front. Genet. 2013, 4, 1-13. [CrossRef] [PubMed]

100. Kopelman, N.M.; Mayzel, J.; Jakobsson, M.; Rosenberg, N.A.; Mayrose, I. Clumpak: A program for identifying clustering modes and packaging population structure inferences across K. Mol. Ecol. Resour. 2015, 15, 1179-1191. [CrossRef] [PubMed]

101. Evanno, G.; Regnaut, S.; Goudet, J. Detecting the number of clusters of individuals using the software STRUCTURE: A simulation study. Mol. Ecol. 2005, 14, 2611-2620. [CrossRef] [PubMed]

102. Earl, D.A.; von Holdt, B.M. STRUCTURE HARVESTER: A website and program for visualizing STRUCTURE output and implementing the Evanno method. Conserv. Genet. Resour. 2012, 4, 359-361. [CrossRef]

103. Hanewinkel, M.; Cullmann, D.A.; Schelhaas, M.; Nabuurs, G.; Zimmermann, N.E. Climate change may cause severe loss in the economic value of European forest land. Nat. Clim. Chang. 2012, 3, 203-207. [CrossRef]

104. Reif, A.; Brucke, U.; Kratzer, R.; Schmiedinger, A.; Bauhus, J. Waldbau und Baumartenwahl in Zeiten des Klimawandels aus Sicht des Naturschutzes; Bundesamt für Naturschutz (BfN): Bonn, Germany, 2010.

105. Kaplan, J.O.; Krumhardt, K.M.; Zimmermann, N. The prehistoric and preindustrial deforestation of Europe. Quat. Sci. Rev. 2009, 28, 3016-3034. [CrossRef]

106. Farrell, E.P.; Führer, E.; Ryan, D.; Andersson, F.; Hüttl, R.; Piussi, P. European forest ecosystems: Buildind the future on the legacy of the past. For. Ecol. Manag. 2000, 132, 5-20. [CrossRef]

107. Finkeldey, R.; Ziehe, M. Genetic implications of silvicultural regimes. For. Ecol. Manag. 2004, 197, $231-244$. [CrossRef]

108. Hosius, B.; Leinemann, L.; Konnert, M.; Bergmann, F. Genetic aspects of forestry in the central Europe. Eur. J. For. Res. 2006, 125, 407-417. [CrossRef]

109. Wegener, U.; Kison, H. Die Vegetation des Brockens im Nationalpark Hochharz (Exkursion G). Tuexenia 2002, 22, 243-267.

110. Meirmans, P.G.; Hedrick, P.W. Assessing population structure: $F_{\mathrm{ST}}$ and related measures. Mol. Ecol. Resour. 2011, 11, 5-18. [CrossRef] [PubMed]

111. Whitlock, M.C. $G^{\prime}$ ST and D do not replace $F_{\mathrm{ST}}$. Mol. Ecol. 2011, 20, 1083-1091. [CrossRef]

112. Deleuze, C.; Hervé, J.C.; Colin, F.; Ribeyrolles, L. Modelling crown shape of Picea abies: Spacing effects. Can. J. For. Res. 1996, 26, 1957-1966. [CrossRef]

113. Grassi, G.; Giannini, R. Influence of light and competition on crown and shoot morphological parameters of Norway spruce and silver fir saplings. Ann. For. Sci. 2005, 62, 269-274. [CrossRef]

114. Hertel, D.; Schöling, D. Below-ground response of Norway spruce to climate conditions at Mt. Brocken (Germany)_A re-assessment of Central Europe's northernmost treeline. Flora Morphol. Distrib. Funct. Ecol. Plants 2011, 206, 127-135. [CrossRef]

115. Schmidt-Vogt, H. Monographie der Picea abies (L.) Karst. unter Berücksichtigung genetischer und züchterischer Aspekte. Forstwiss. Cent. 1978, 97, 281-302. [CrossRef]

116. Bergmann, F. The allelic distribution at an acid phosphatase locus in Norway spruce (Picea abies) along similar climatic gradients. Theor. Appl. Genet. 1978, 52, 57-64. [CrossRef] [PubMed]

117. Lagercrantz, U.; Ryman, N. Genetic structure of Norway spruce (Picea abies): Concordance of Morphological and Allozymic Variation. Evolution 1990, 44, 38-53. [CrossRef] [PubMed]

118. Chen, J.; Källman, T.; Ma, X.; Gyllenstrand, N.; Zaina, G.; Morgante, M.; Bousquet, J.; Eckert, A.; Wegrzyn, J.; Neale, D.; et al. Disentangling the roles of history and local selection in shaping clinal variation of allele frequencies and gene expression in Norway spruce (Picea abies). Genetics 2012, 191, 865-881. [CrossRef] [PubMed]

119. Trujillo-Moya, C.; George, J.-P.; Fluch, S.; Geburek, T.; Grabner, M.; Karanitsch-Ackerl, S.; Konrad, H.; Mayer, K.; Sehr, E.M.; Wischnitzki, E.; et al. Drought sensitivity of Norway Spruce at the species' warmest fringe: Quantitative and molecular analysis reveals high genetic variation among and within provenances. G3 Genes Genomes Genet. 2018. [CrossRef] [PubMed] 
120. Ganthaler, A.; Stöggl, W.; Mayr, S.; Kranner, I.; Schüler, S.; Wischnitzki, E.; Sehr, E.M.; Fluch, S.; Trujillo-Moya, C. Association genetics of phenolic needle compounds in Norway spruce with variable susceptibility to needle bladder rust. Plant Mol. Biol. 2017, 94, 229-251. [CrossRef] [PubMed]

121. Radu, R.G.; Curtu, L.A.; Spârchez, G.; Şofletea, N. Genetic diversity of Norway spruce (Picea abies (L.) Karst.) in Romanian Carpathians. Ann. For. Res. 2014, 57, 19-29. [CrossRef]

122. Unger, G.M.; Konrad, H.; Geburek, T. Does spatial genetic structure increase with altitude? An answer from Picea abies in Tyrol, Austria. Plant Syst. Evol. 2011, 292, 133-141. [CrossRef]

123. Scotti, I.; Paglia, G.; Magni, F.; Morgante, M. Population genetics of Norway spruce (Picea abies Karst.) at regional scale: Sensitivity of different microsatellite motif classes in detecting differentiation. Ann. For. Sci. 2006, 63, 485-491. [CrossRef]

124. Muona, O.; Paule, L.; Szmidt, A.E.; Kärkkäinen, K. Mating system analysis in a central and northern European population of Picea abies. Scand. J. For. Res. 1990, 5, 97-102. [CrossRef]

125. Chevarria, M.V. Genetic Characterisation of Populations from the European Natural Range of Norway Spruce (Picea abies (L.) Karst.) by Means of EST Markers. Ph.D. Thesis, Technische Universität München, Munich, Germany, 9 March 2005.

126. Geburek, T. Genetic variation of Norway spruce (Picea abies (L.) Karst.) populations in Austria. III. Macrospatial allozyme patterns of high elevation populations. Int. J. For. Genet. 1999, 6, 201-211.

127. Máchová, P.; Trčková, O.; Cvrčková, H. Use of nuclear microsatellite loci for evaluating genetic diversity of selected populations of Picea abies (L.) Karsten in the Czech Republic. Forests 2018, 9, 92. [CrossRef]

128. Jeandroz, S.; Collignon, A.M.; Favre, J.M. RAPD and mtDNA variation among autochthonous and planted populations of Picea abies from the Vosges mountains (France) in reference to other French populations. For. Ecol. Manag. 2004, 197, 225-229. [CrossRef]

129. Janes, J.K.; Miller, J.M.; Dupuis, J.R.; Malenfant, R.M.; Gorrell, J.C.; Cullingham, C.I.; Andrew, R.L. The $K=2$ conundrum. Mol. Ecol. 2017, 3594-3602. [CrossRef] [PubMed]

130. Ennos, R.A. Estimating the relative rates of pollen and seed migratin among plant populations. Heredity 1994, 72, 250-259. [CrossRef]

131. QGIS Development Team. QGIS Geographic Information System. Open Source Geospatial Found. Project. Available online: http:/ / www.qgis.org/ (accessed on 18 December 2017).

132. OpenStreetMap Contributors. OpenStreetMap. Available online: http:/ / tile.openstreetmap.org (accessed on 18 October 2018).

(c) 2018 by the authors. Licensee MDPI, Basel, Switzerland. This article is an open access article distributed under the terms and conditions of the Creative Commons Attribution (CC BY) license (http:/ / creativecommons.org/licenses/by/4.0/). 


\subsection{Chapter I - Supplementary Materials}

\section{Supplementary Information for: High morphological differentiation in crown architecture contrasts with low population genetic structure of German Norway spruce stands}

\section{Oliver Caré, Markus Müller, Barbara Vornam, Aki M. Höltken, Karina Kahlert, Konstantin V. Krutovsky, Oliver Gailing*, Ludger Leinemann}

Correspondence: ogailin@gwdg.de

Table S1: Concentration $\left(\mathcal{C}_{\mathrm{i}}\right)$ of each forward and reverse primer in the multiplex reactions and single-plex.

\begin{tabular}{|c|c|c|c|c|c|c|c|c|c|}
\hline \multicolumn{2}{|c|}{ Singleplex } & \multicolumn{2}{|c|}{ Multiplex 1} & \multicolumn{2}{|c|}{ Multiplex 2} & \multicolumn{2}{|c|}{ Multiplex 3} & \multicolumn{2}{|c|}{ Multiplex 4} \\
\hline SSR & $\begin{array}{l}c_{\mathrm{i}} \\
(\mu \mathrm{M} / \mu \mathrm{l})\end{array}$ & SSR & $\begin{array}{l}C_{\mathrm{i}} \\
(\mu \mathrm{M} / \mu \mathrm{l})\end{array}$ & SSR & $\begin{array}{l}\mathcal{C}_{\mathrm{i}} \\
(\mu \mathrm{M} / \mu \mathrm{l})\end{array}$ & SSR & $\begin{array}{l}\mathcal{C}_{\mathrm{i}} \\
(\mu \mathrm{M} / \mu \mathrm{l})\end{array}$ & SSR & $\begin{array}{l}C_{\mathrm{i}} \\
(\mu \mathrm{M} / \mu \mathrm{l})\end{array}$ \\
\hline \multirow[t]{3}{*}{$P a G B 8$} & 3.57 & WS00111.K13 & 3.57 & $S p A G C 1$ & 2.14 & EATC1E03 & 1.25 & SpAGG2 & 1.79 \\
\hline & & EATC1D2 & 2.14 & EATC2G05 & 2.14 & SpAG2 & 1.79 & WS00016.009 & 3.57 \\
\hline & & & & EATC1B2 & 1.07 & SpAC1F07 & 3.57 & $\mathrm{PaGB3}$ & 1.07 \\
\hline
\end{tabular}

Table S2: Relative frequencies of assessed morphological traits in each stand corresponding to the Figure 1 in the main paper. Stand abbreviation: LE: Low elevation type; HE: High elevation type; SBF: relict stand "Schlossbergfichte"; S: Ore Mountains (Saxony); Thy: Thuringia; H: Harz Mountains.

\begin{tabular}{ccccccccc}
\hline & & HE_H & LE_H & HE_S & LE_S & SBF_Thy & HE_Thy & LE_Thy \\
\hline \multirow{3}{*}{ crown shape } & narrow & 0.374 & 0.005 & 0.565 & 0.030 & 1.000 & 0.545 & 0.000 \\
& intermediate & 0.626 & 0.315 & 0.375 & 0.730 & 0.000 & 0.455 & 0.035 \\
& broad & 0.000 & 0.680 & 0.060 & 0.240 & 0.000 & 0.000 & 0.965 \\
downwards & 0.865 & 0.025 & 0.655 & 0.065 & 1.000 & 0.555 & 0.000 \\
branching anle & intermediate & 0.135 & 0.430 & 0.345 & 0.660 & 0.000 & 0.445 & 0.175 \\
& upwards & 0.000 & 0.545 & 0.000 & 0.275 & 0.000 & 0.000 & 0.825 \\
branching pattern & plate & 0.730 & 0.000 & 0.365 & 0.025 & 1.000 & 0.545 & 0.000 \\
& intermediate & 0.207 & 0.400 & 0.625 & 0.485 & 0.000 & 0.455 & 0.355 \\
comb & 0.063 & 0.600 & 0.010 & 0.490 & 0.000 & 0.000 & 0.645 \\
crown damage & no & 0.000 & 0.060 & 0.915 & 0.955 & 1.000 & 1.000 & 0.000 \\
& yes & 1.000 & 0.940 & 0.085 & 0.045 & 0.000 & 0.000 & 1.000 \\
no & no & 0.000 & 0.665 & 0.960 & 0.970 & 1.000 & 1.000 & 0.460 \\
& yes & 1.000 & 0.335 & 0.040 & 0.030 & 0.000 & 0.000 & 0.540 \\
\hline
\end{tabular}

All values are rounded to three decimals. 
Table S3: Hierarchical AMOVA based on the regional and population membership of the individuals.

\begin{tabular}{cccccc}
\hline Source of variation & d.f. & $\begin{array}{c}\text { Sum of } \\
\text { squares }\end{array}$ & $\begin{array}{c}\text { Variance } \\
\text { component }\end{array}$ & $\begin{array}{c}\text { Percentage } \\
\text { variation }\end{array}$ & P-value \\
\hline $\begin{array}{c}\text { Among regions } \\
\text { Among populations within } \\
\text { regions }\end{array}$ & 2 & 30.1 & 0.00945 & 0.24 & 0.05833 \\
$\begin{array}{c}\text { Among individuals within } \\
\text { populations }\end{array}$ & 4 & 26.5 & 0.00642 & 0.16 & $<0.0002$ \\
$\begin{array}{c}\text { Within individuals } \\
\text { Total }\end{array}$ & 1290 & 5618.7 & 0.37536 & 9.39 & $<0.0002$ \\
\hline
\end{tabular}

Significance of the (co-) variance components based on 5000 permutations, both calculated in Arlequin 3.5.2.2 [76].

Table S4: Pairwise Fst values between population pairs (bolt) with corresponding p-values from 10000 permutations in GenAlEx 6.5 [77].

\begin{tabular}{ccccccc}
\hline & HE_H & HE_S & HE_Thy & LE_H & LE_S & LE_Thy \\
\hline HE_S & $\mathbf{0 . 0 0 4}$ & & & & & \\
& 0.000 & & & & & \\
HE_Thy & $\mathbf{0 . 0 0 4}$ & $\mathbf{0 . 0 0 3}$ & & & & \\
& 0.000 & 0.000 & & & & \\
LE_H & $\mathbf{0 . 0 0 2}$ & $\mathbf{0 . 0 0 4}$ & $\mathbf{0 . 0 0 4}$ & & & \\
& 0.153 & 0.000 & 0.000 & & & \\
LE_S & $\mathbf{0 . 0 0 3}$ & $\mathbf{0 . 0 0 2}$ & $\mathbf{0 . 0 0 3}$ & $\mathbf{0 . 0 0 4}$ & & \\
& 0.000 & 0.000 & 0.000 & 0.000 & & \\
LE_Thy & $\mathbf{0 . 0 0 3}$ & $\mathbf{0 . 0 0 2}$ & $\mathbf{0 . 0 0 3}$ & $\mathbf{0 . 0 0 4}$ & $\mathbf{0 . 0 0 2}$ & \\
& 0.000 & 0.003 & 0.000 & 0.000 & 0.059 & \\
SBF_Thy & $\mathbf{0 . 0 0 6}$ & $\mathbf{0 . 0 0 5}$ & $\mathbf{0 . 0 0 3}$ & $\mathbf{0 . 0 0 7}$ & $\mathbf{0 . 0 0 5}$ & $\mathbf{0 . 0 0 4}$ \\
& 0.000 & 0.001 & 0.028 & 0.000 & 0.000 & 0.001 \\
\hline
\end{tabular}

Table S5: Pairwise G"sT values between population pairs in GenAlEx 6.5 [77].

\begin{tabular}{ccccccc}
\hline & HE_H & HE_S & HE_Thy & LE_H & LE_S & LE_Thy \\
\hline HE_S & 0.024 & & & & & \\
HE_Thy & 0.021 & 0.009 & & & & \\
LE_H & 0.002 & 0.022 & 0.022 & & & \\
LE_S & 0.011 & 0.008 & 0.010 & 0.016 & & \\
LE_Thy & 0.016 & 0.007 & 0.009 & 0.022 & 0.003 & \\
SBF_Thy & 0.026 & 0.016 & 0.008 & 0.030 & 0.017 & 0.014 \\
\hline
\end{tabular}

$p$-values are identical to Table S4 and therefore not given. 


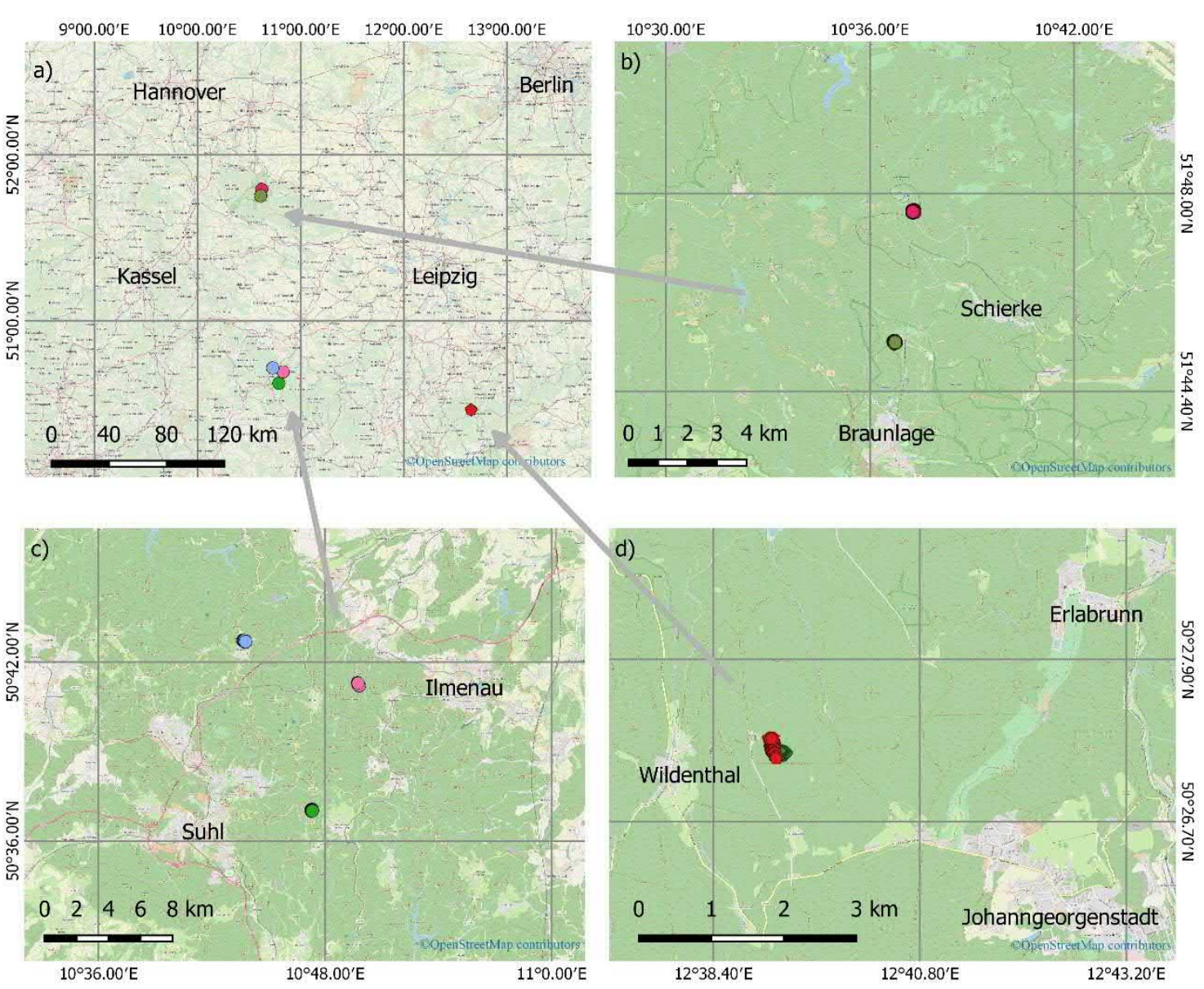

Figure S1 a-d: Overview map (a) and map sections of the stand locations. Harz region (b) with the northern high elevation (HE) and southern low elevation (LE) stand. Thuringian forest (c) with the northern relict stand "Schlossbergfichte", the southern LE stand and the more eastern HE stands. Ore mountains in Saxony (d) with the western HE stand and eastern LE stand. Longitudinal and latitudinal coordinates are given on the corresponding sides of each map. Maps generated with QGIS 2.18.15 [132] using geodata from www.openstreetmaps.org[133]. 


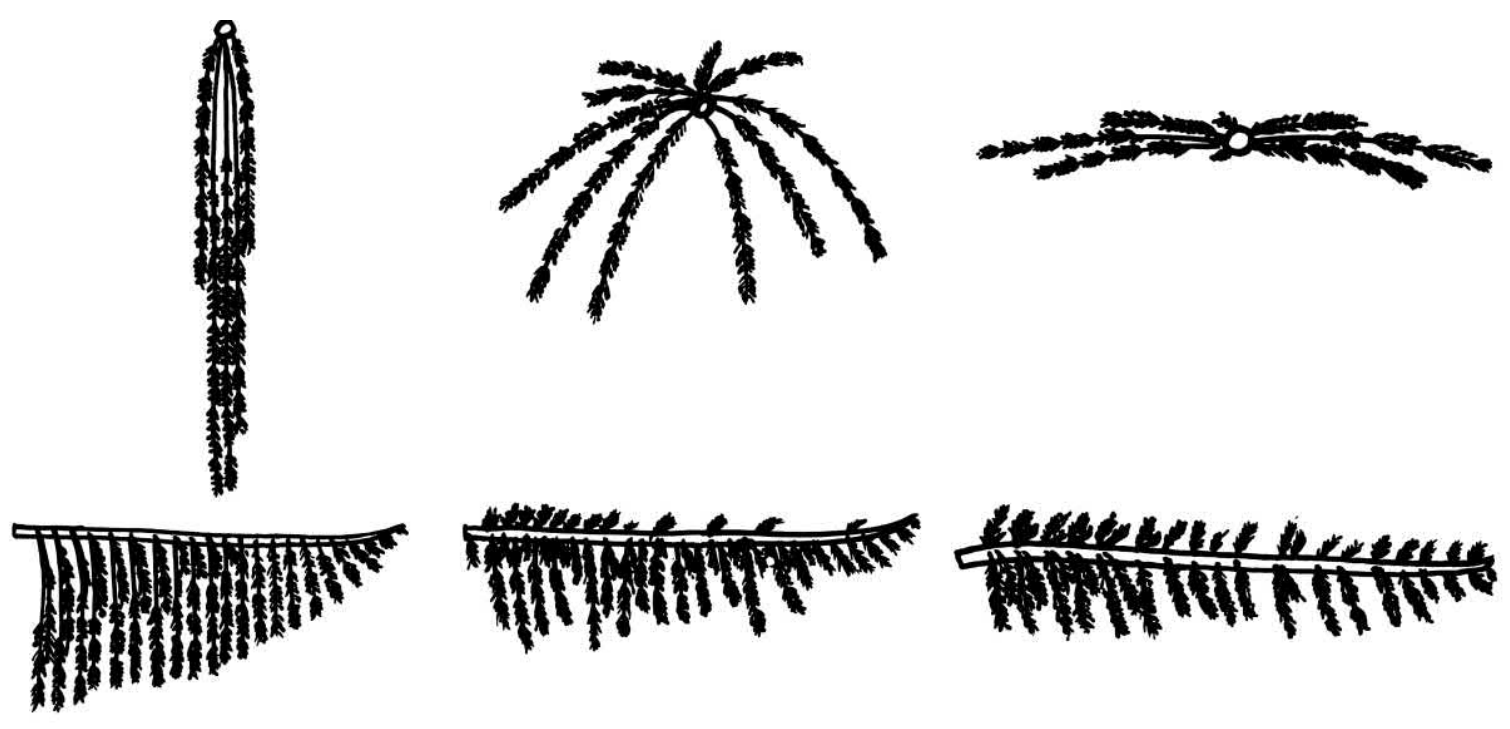

Figure S2: Schematic presentation of the three main crown architectural types. From left to right, lowland combe type, intermediate brush type and narrow high elevation plate type. Top secondary branching pattern as cross-sectional view and bottom in side view (Figures modified and reproduced with permission from J. D. Sauerländer's Verlag; Gruber, Allg. Forst- u. J.-Ztg,160, published by J. D. Sauerländer's Verlag, 1989 [5]).

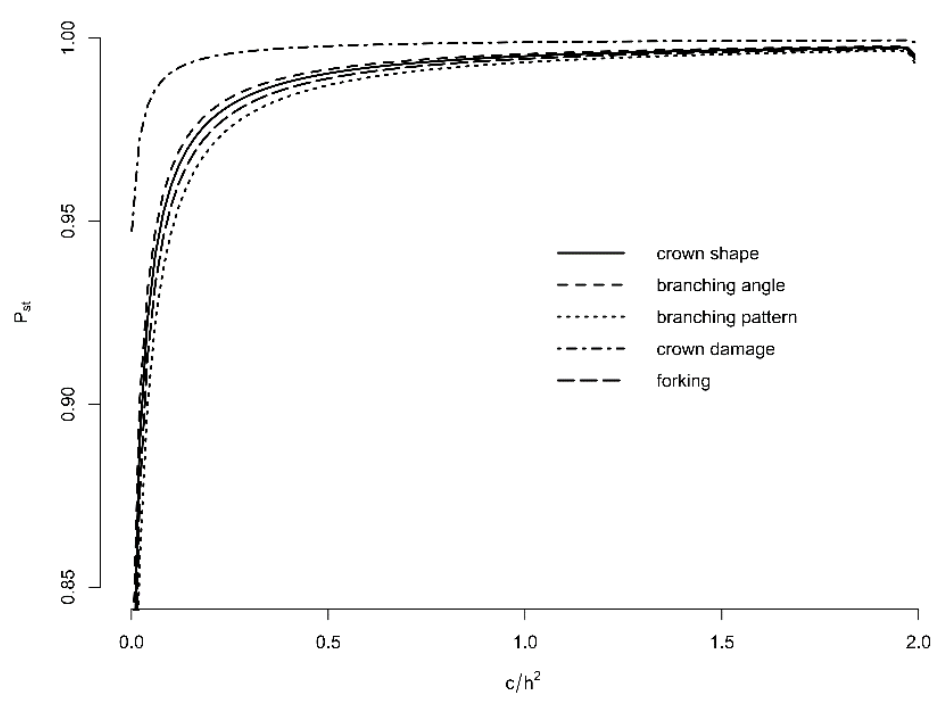

Figure S3: Relationship of phenotypic divergence in a trait across populations ( $P_{\text {Sт) }}$ [60-62] over the ratio of the total variance explained by additive genetic effects across populations and the narrow sense heritability $\left(c / h^{2}\right)$ 


\section{deviation from HWE p-vales (LLR)}

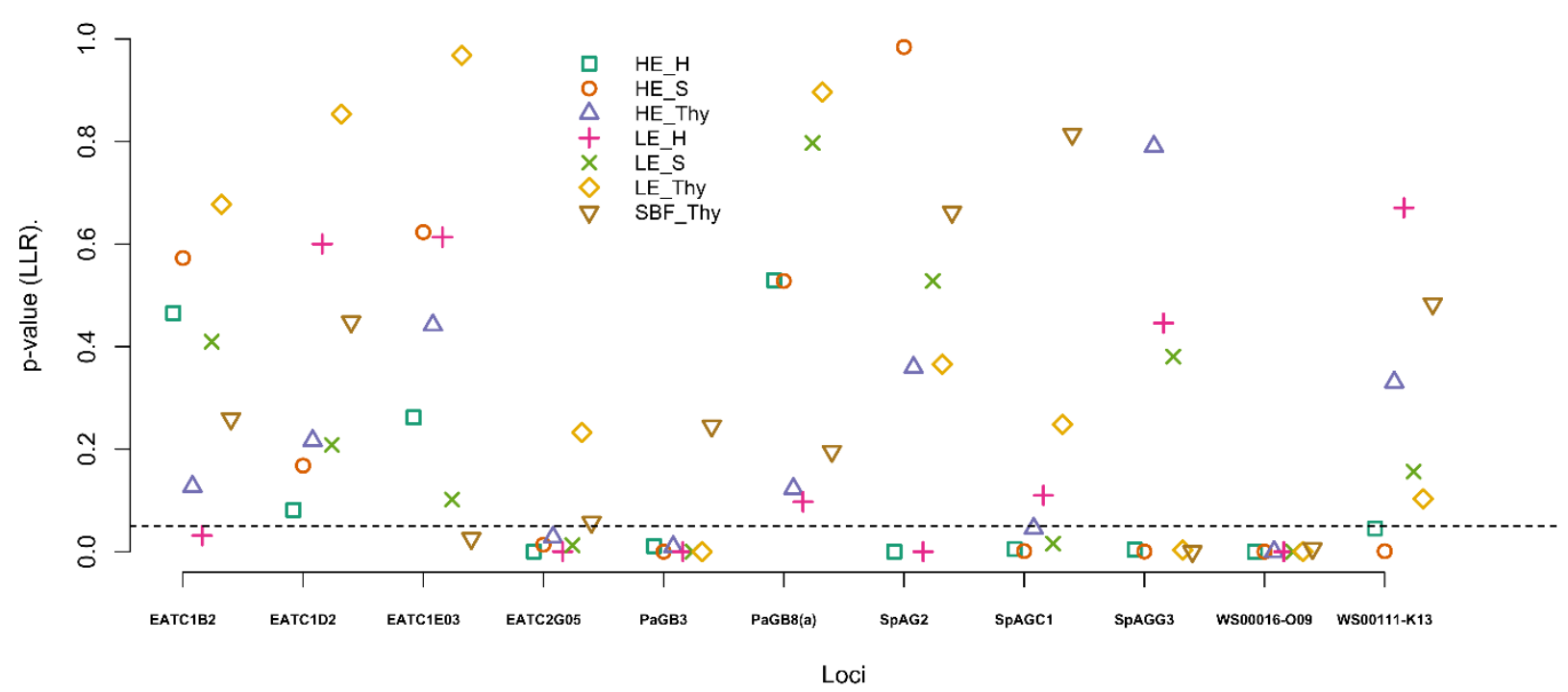

Figure S4: Corresponding p- value of the log likelihood ratio test on the deviation from HWE of each locus genotyped in each population sampled. Test statistic is based on either full enumeration or Monte Carlo sampling on the count tables depended on the number of tables to be observe (for details see $[67,68]$ ).

estimated null allele freqencies

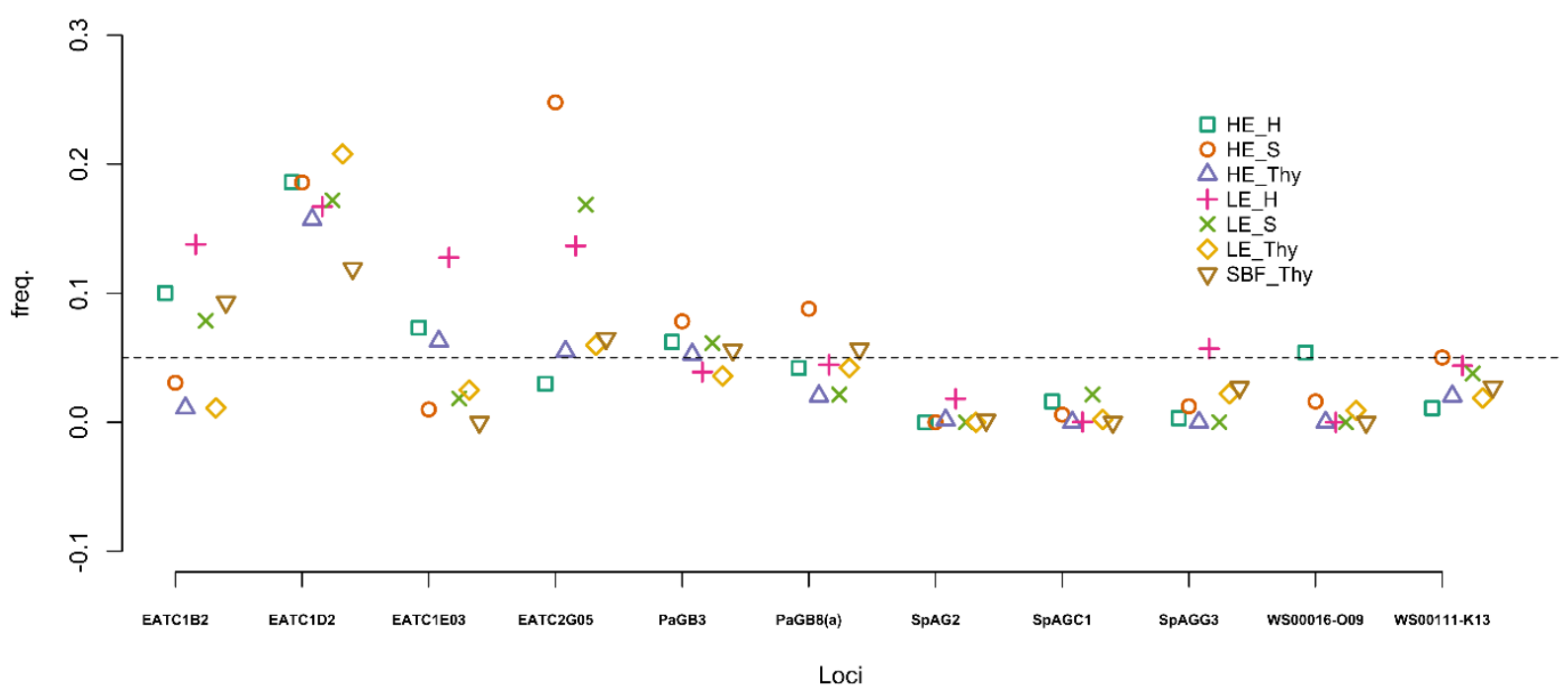

Figure S5: Estimation of the null allele frequency at each locus in each population separately. Average of maximum likelihood estimation expectation maximisation [71] in genepop [72] and ML estimation in MLNullfreq [73]. Dashed line indicating the estimated 5\% frequency, as it can be seen as a threshold value for reporting null alleles [74]. 

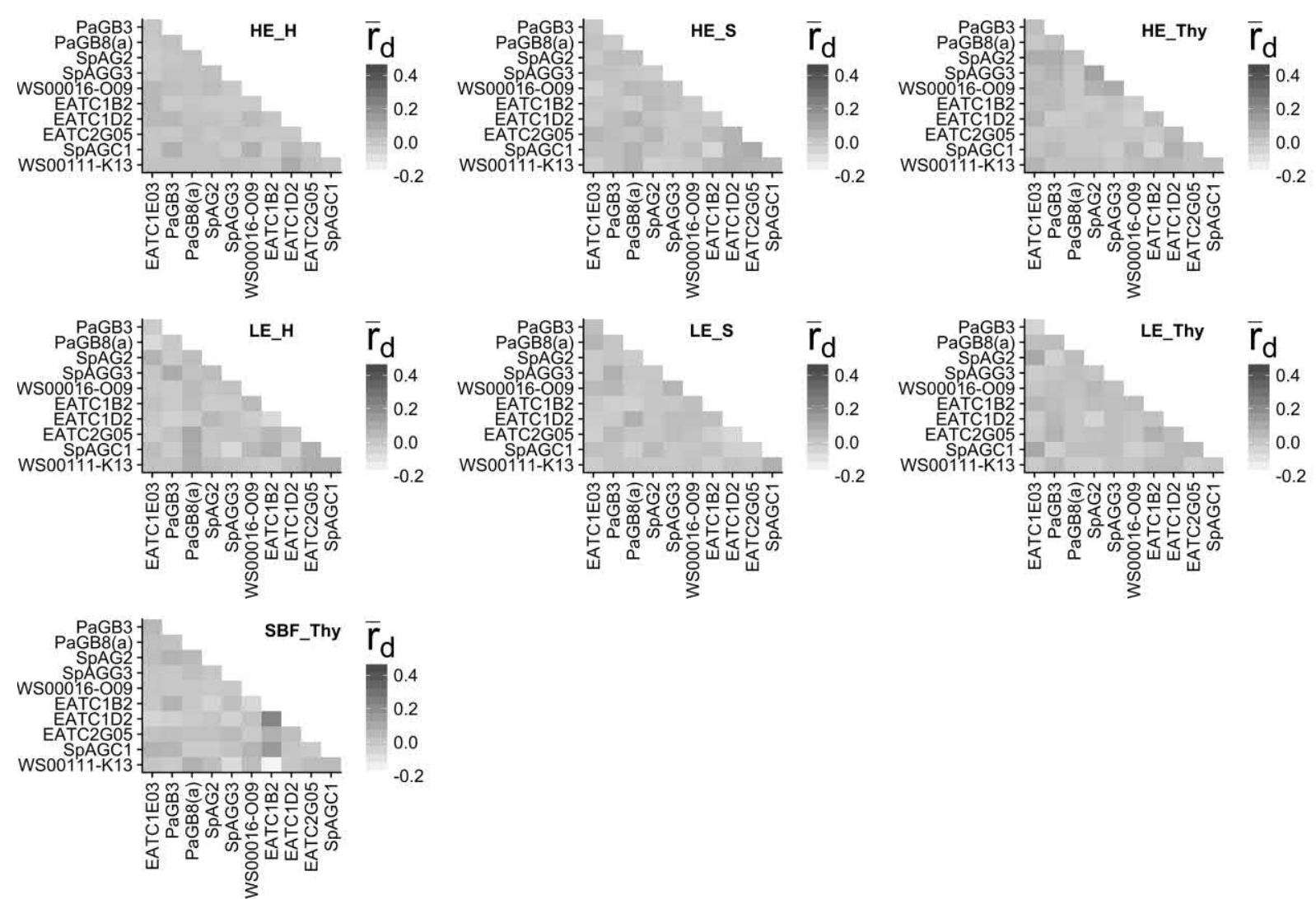

Figure S6: Heatmaps displaying the standardizes index of association $\bar{r}_{d}$ [69] for pairwise loci comparison for each stand separately. Low values are indicated in white, whereas higher values are indicated with increasing grey shades. Stand abbreviation: LE: Low elevation type; HE: High elevation type; SBF: relict stand “Schlossbergfichte"; S: Ore Mountains (Saxony); Thy: Thuringia; H: Harz Mountains.

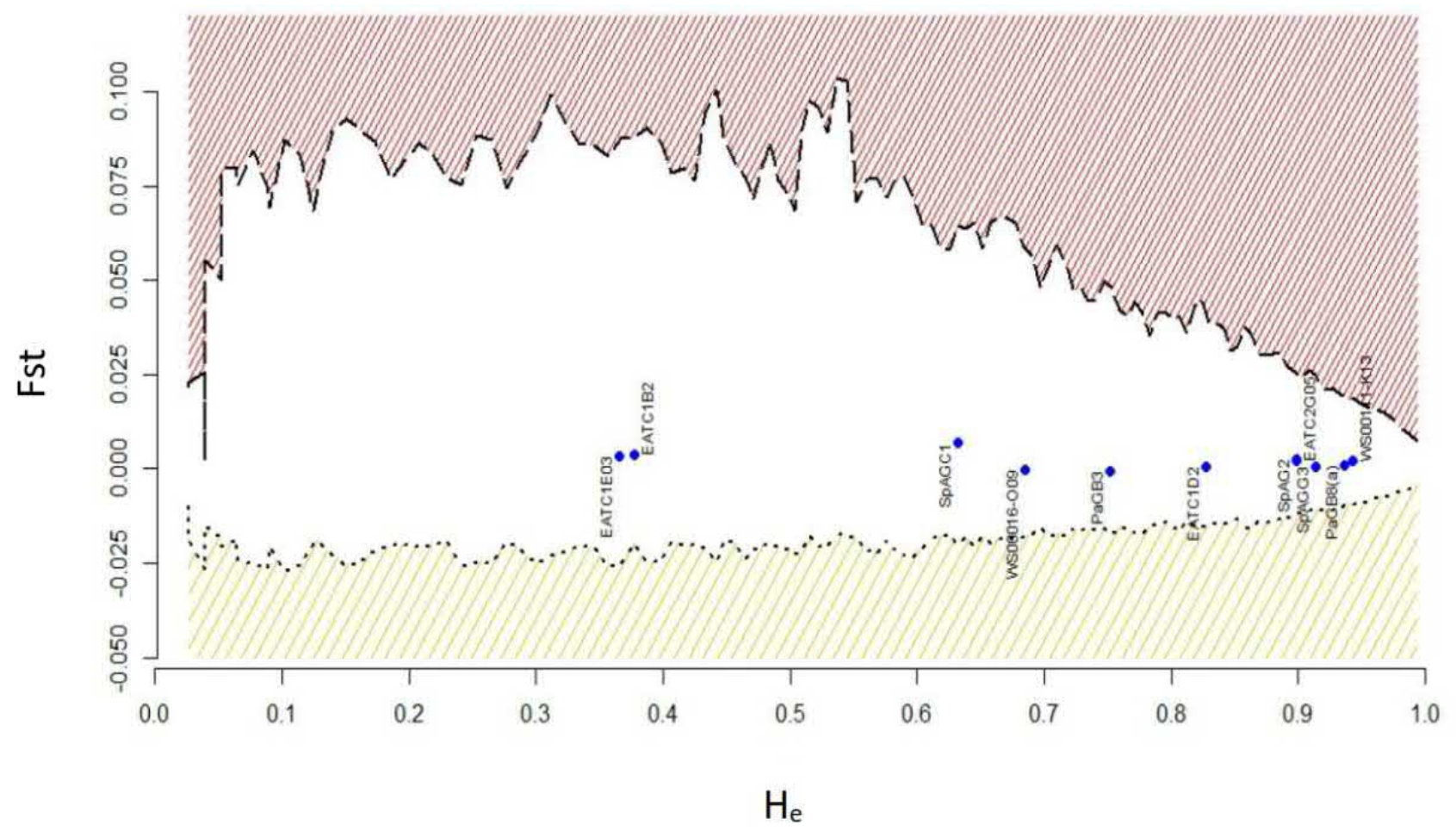

Figure S7: Detection of outlier loci in LOSITAN [82] exploring the relationship between $F_{\mathrm{ST}}$ and $H_{\mathrm{e}}$ among populations by permutations. Black dashed lines indicate the upper $95 \%$ confidence limit, also highlighted by fine red hatching. Black dotted lines indicate the lower $95 \%$ confidence limit, highlighted by rougher yellow hatching. 


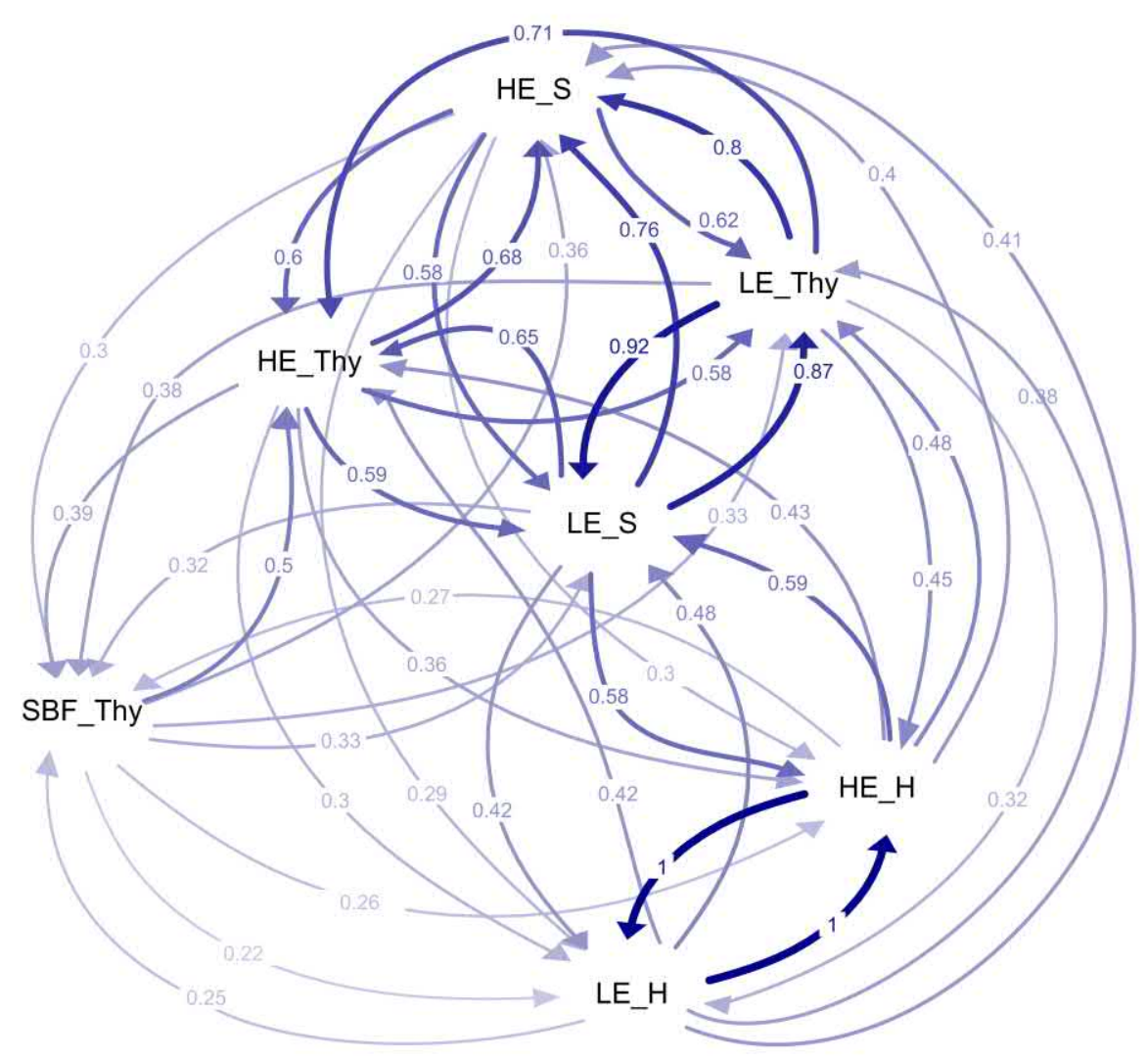

Figure S8: Directional relative migration network [85] based on Gsт [86] of potential allochthones and autochthones populations. The relative positions of the populations indicate relatedness from the perspective of hypothetical gene flow. Numbers and arrows indicate the direction and extent of gene flow (also underlined by arrow shading/thickness). Stand abbreviations: LE: Low elevation type; HE: High elevation type; SBF: relict stand "Schlossbergfichte"; S: Ore Mountains (Saxony); Thy: Thuringia; H: Harz Mountains. 

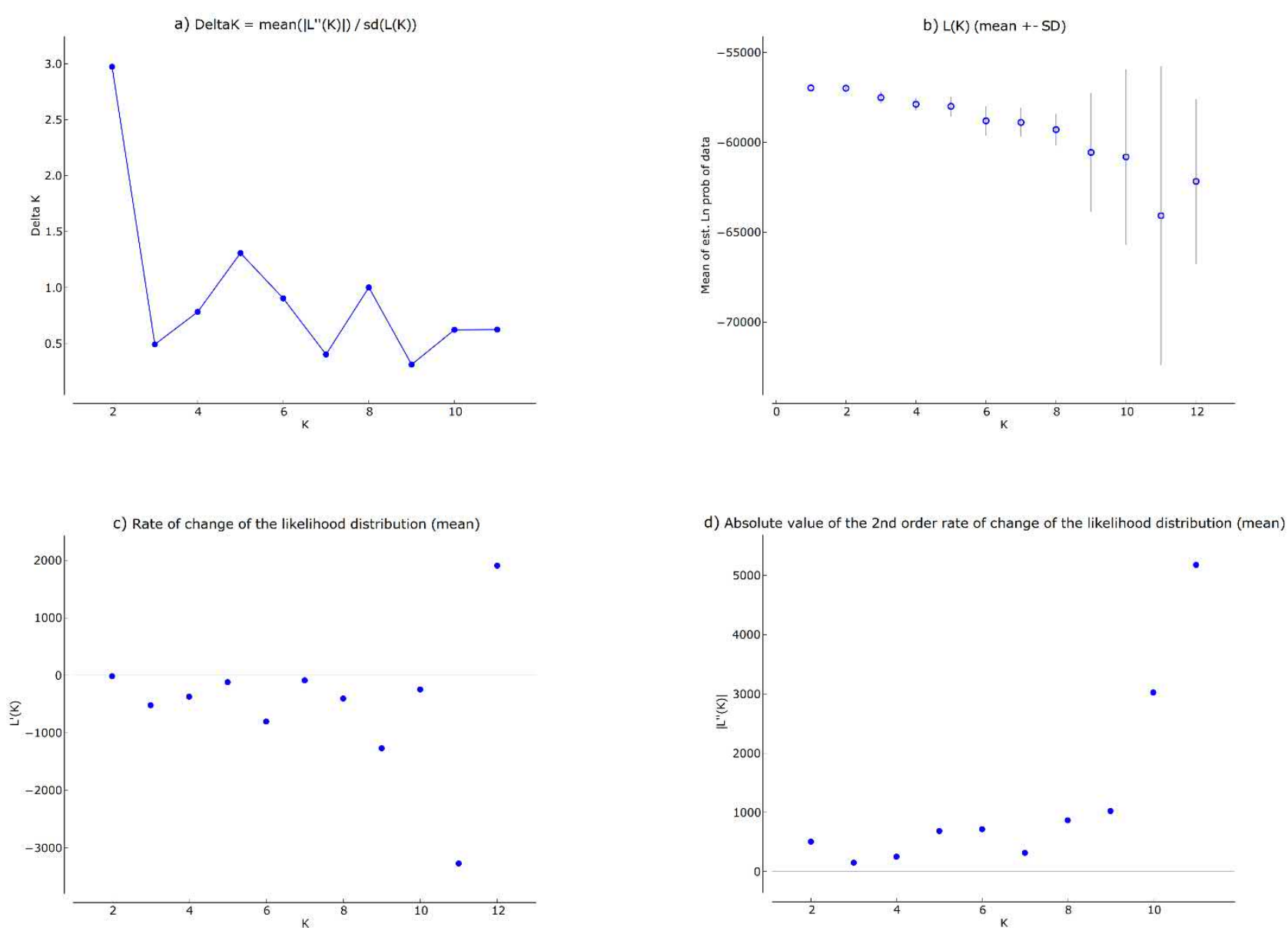

Figure S9 (a-d): Detection of the number of clusters K according to a) DeltaK [101], the b) log-likelihood probability of $K(L(K))$ and the corresponding c) first and d) second order change of $L(K)$ [96] calculated in STRUCTURE HARVESTER [102]. 


\section{Major modes}

$\mathrm{K}=2$

runs: $8 / 15$

LnProb mean: -57021.988

Mean similarity score: 0.97

$\mathrm{K}=3$

runs: 10/15

LnProb mean: -57549.650

Mean similarity score: 0.887

$\mathrm{K}=4$

runs: $8 / 15$

LnProb mean: -57830.900

Mean similarity score: 0.923

$\mathrm{K}=5$

runs: $8 / 15$

LnProb mean: -57936.312

Mean similarity score: 0.932

$\mathrm{K}=6$

runs: $8 / 15$

LnProb mean: -59130.287

Mean similarity score: 0.92

$\mathrm{K}=7$

runs: $11 / 15$

LnProb mean: -58665.209

Mean similarity score: 0.891

$\mathrm{K}=8$

runs: $14 / 15$

LnProb mean: -59331.250

Mean similarity score: 0.928

$\mathrm{K}=9$

runs: $13 / 15$

LnProb mean: -60807.577

Mean similarity score: 0.927

$\mathrm{K}=10$

runs: $14 / 15$

LnProb mean: -60976.350

Mean similarity score: 0.919

$\mathrm{K}=11$

runs: $12 / 15$

LnProb mean: -63444.642

Mean similarity score: 0.927

$\mathrm{K}=12$

runs: $14 / 15$

LnProb mean: -61776.579

Mean similarity score: 0.932
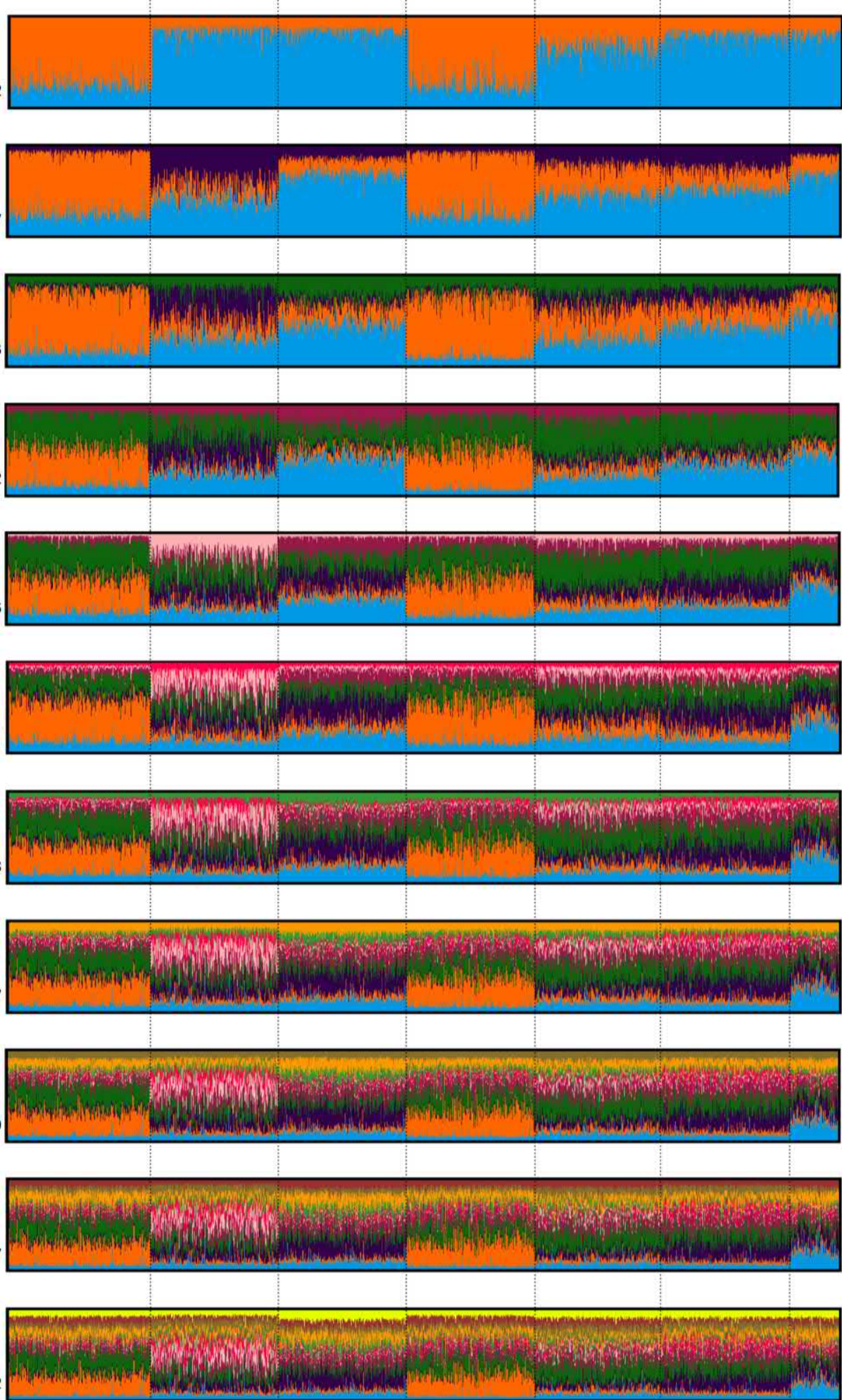

HE_H

HE_S

HE_Thy

LE_H

LE_S

LE_Thy SBF_Thy

Figure S10: Major modes of cluster results from K 2 to 12 of STRUCTURE [96] analysis summarised in CLUMPAK [100]. For each $\mathrm{K}$ the major mode is given indication the number of runs and der mean similarity of the summarisation output as well as the mean ln probability of the mode. Individuals ordered by population membership as indicated at the bottom. 
6. Chapter II - Crown morphology in Norway spruce (Picea abies [KARST.] L.) as adaptation to mountainous environments is associated with single nucleotide polymorphisms (SNPs) in genes regulating seasonal growth rhythm

Oliver Caré, Oliver Gailing, Markus Müller, Krutovsky, Ludger Leinemann

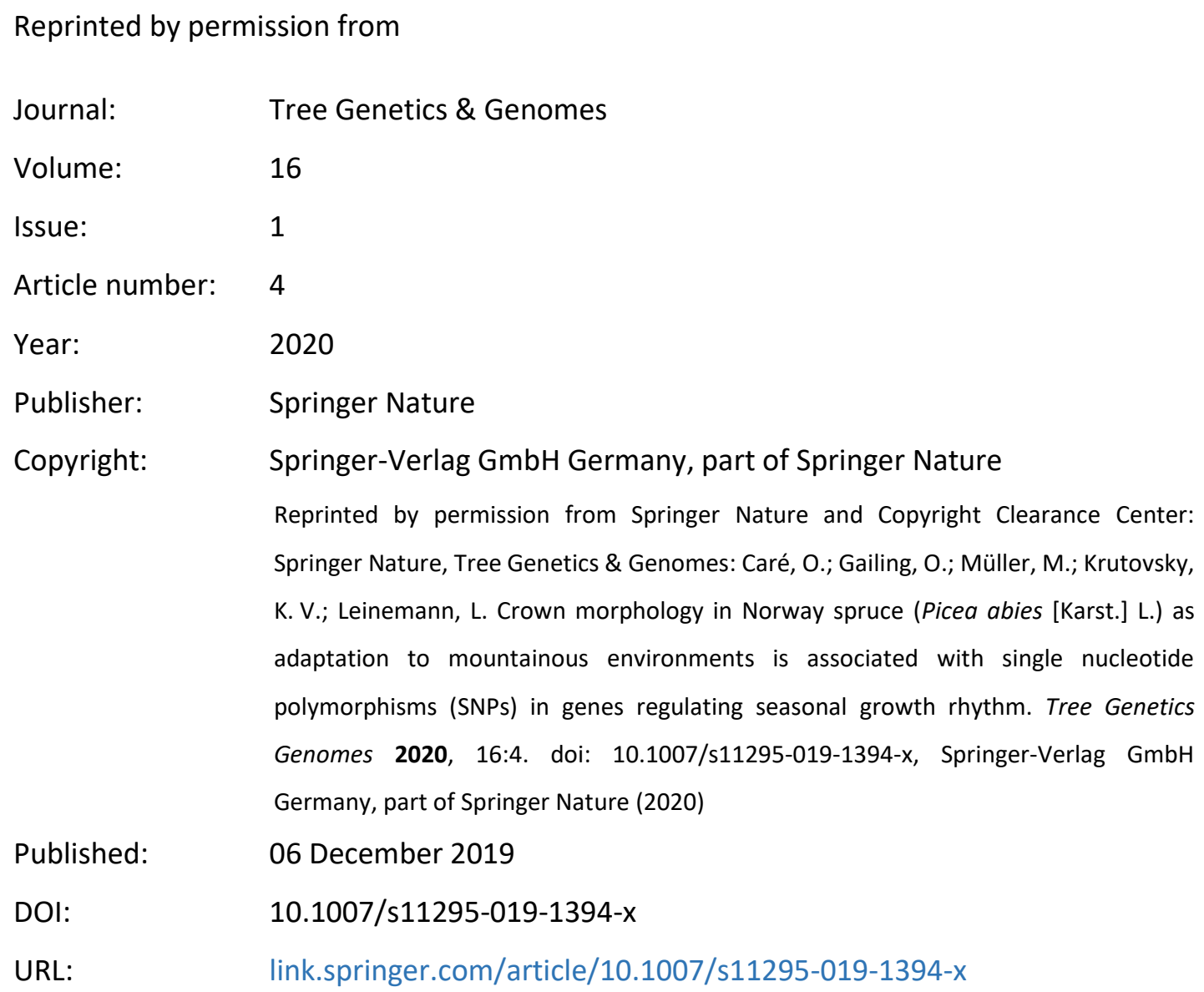

Autor contributions:

Conceptualization: O.C., O.G., M.M., K.K. and L.L.; Methodology: O.C., O.G., M.M., K.K. and L.L.; Software: O.C.; Validation: O.C., O.G., M.M., K.K. and L.L.; Formal analysis: O.C.; Investigation: O.C.; Data curation, O.C.; Writing-original draft preparation, O.C.; Writing-review and editing, O.C., O.G., M.M., K.K. and L.L.; Visualization, O.C.; Supervision, O.G. and L.L.; Project administration, O.G. and L.L.; Funding acquisition, O.G., M.M, and L.L. (listed based on position in author list, CRediT taxonomy) 


\title{
Crown morphology in Norway spruce (Picea abies [KaRST.] L.) as adaptation to mountainous environments is associated with single nucleotide polymorphisms (SNPs) in genes regulating seasonal growth rhythm
}

\author{
Oliver Caré ${ }^{1,2}$ (D) $\cdot$ Oliver Gailing $^{1,2}($ D $) ~$ Markus Müller $^{1}$ (D) $\cdot$ Konstantin V. Krutovsky $^{1,2,3,4,5}$ (D) $\cdot$ Ludger Leinemann $^{1}$
}

Received: 1 August 2019 / Revised: 23 September 2019 / Accepted: 2 October 2019

(C) Springer-Verlag GmbH Germany, part of Springer Nature 2019

\begin{abstract}
Trees growing at high altitude or latitude have to be adapted, among others, to the lower temperatures, a shorter vegetation period, heavier snow load, and frost desiccation. Association between molecular genetic markers and climatic variables may provide evidence for the genetic control of climatic adaptation. With increasing genomic resources, several genes with importance to climatic adaptation are identified over a wide range of tree species. Commonly, circadian clock genes are linked to the adaptation to lower temperatures and especially to a shortened vegetation period, as they are regulating metabolic and phenological processes in the day-night shift and seasonal change. Potentially adaptive "candidate" genes associated with latitudinal and elevational gradients were identified in several Picea spp. Before molecular markers became available to study climatic adaptation and phenotypic traits measured in natural populations, and/or common garden studies were used to search for their association with climate variables. In Norway spruce, the crown architecture is the most noticeable trait associated with altitude and the related environment. The mountainous narrow-crowned morphotype is characterized by superior resistance to snow breakage in regions with heavy snowfall. In total, the crown shape was assessed in 765 individual trees from mountainous regions in the Thuringian Forest, the Ore Mountains (Saxony), and Harz Mountains (Lower-Saxony/Saxony-Anhalt), and they were genotyped at 44 single nucleotide polymorphisms (SNPs) in 24 adaptive trait-related candidate genes. Six SNPs in three genes, APETALA 2-like 3 (AP2L3), GIGANTEA $(G I)$, and mitochondrial transcription termination factor ( $m T E R F)$ were associated with variation in crown shape. $G I$ has previously been identified in angiosperms and gymnosperms to be associated with temperature and growth cessation. Our results showed that crown morphology in Norway spruce is associated with genetic markers which are putatively involved in the complex process of genetic adaptation to climatic conditions at high altitudes.
\end{abstract}

Keywords Climatic adaptation $\cdot$ High altitude $\cdot$ Provenances $\cdot$ Norway spruce $\cdot$ Single nucleotide polymorphisms $($ SNPs $) \cdot$ Crown morphology

Communicated by A. Brunner

Electronic supplementary material The online version of this article (https://doi.org/10.1007/s11295-019-1394-x) contains supplementary material, which is available to authorized users.

Oliver Gailing ogailin@gwdg.de

1 Department of Forest Genetics and Forest Tree Breeding, Büsgen-Institute, Faculty of Forest Sciences and Forest Ecology, Georg-August University of Göttingen, 37077 Göttingen, Germany

2 Center for Integrated Breeding Research (CiBreed), Georg-August University of Göttingen, 37075 Göttingen, Germany
3 Department of Ecosystem Science and Management, Texas A\&M University, College Station, TX 77840, USA

4 Laboratory of Population Genetics, Vavilov Institute of General Genetics, Russian Academy of Sciences, 119991 Moscow, Russia

5 Genome Research and Education Centre, Siberian Federal University, 660036 Krasnoyarsk, Russia 


\section{Introduction}

Climatic adaptation is a key component in the evolution of temperate and boreal conifers (Skrøppa and Johnsen 2000). This is especially true for Norway spruce (Picea abies [KARST.] L.), with a wide latitudinal and longitudinal distribution range, as well as inhabiting different altitudinal levels. Hence, individuals of this species are able to grow and reproduce under a variety of ambient conditions. Provenance trials showed that offspring from autochthonous parents growing under harsh conditions (drought, early frost, snow, etc.) often showed better performance than those originating from regions with milder climate (Hannerz and Westin 2005; Liesebach et al. 2010; Kapeller et al. 2012; George et al. 2019). In areas characterized by low temperatures and a short vegetation period, such as high altitudes and latitudes, plants have to adapt by adjusting their growth cycle, freezing tolerance, and frost-drought resistance (Beck et al. 2004; Howe et al. 2004). Their growth performance will nonetheless be reduced compared with provenances from slightly milder climates (Kalela 1937; Liesebach et al. 2010), which may be explained by different allocation patterns, especially to the belowground biomass (Oleksyn et al. 1998; Modrzyński and Eriksson 2002; Hertel and Schöling 2011), and a trade-off between growth in the shorter vegetation period and earlier growth cessation/hardening to avoid freezing damage (Howe et al. 2004). The resistance to the breakage hazard by snow and wind is mainly attributed to the narrow crown shape (Nykänen et al. 1997) observed in provenances from high altitudes or other snow-rich regions (Schmidt-Vogt 1977; Gruber 1993; König 2002; Geburek et al. 2008; Liesebach et al. 2010). This trait is believed to be highly genetically controlled (Sylvén 1909; Kiellander 1962; Gruber 1993). Recently, dependency between the provenance and crown slenderness could be shown in a half-sib field trial (Apostol and Budeanu 2019). Also, the low phenotypic plasticity and stable expression of (planted) broad-crowned phenotypes in some stands heavily damaged by snow/wind breakage are further indications of genetic control and heritability of this trait. Underlying genetic differences in crown shape are especially evident as damaged stands can be found next to the undamaged stands with autochthonous narrow-crowned high-elevation morphotypes (Caré et al. 2018).

High-elevation or northern provenances are also known to have earlier growth cessation and often also earlier leaf flushing (Modrzyński and Eriksson 2002; Chmura 2006) compared with low-elevation or southern provenances grown under similar conditions, a common pattern observed in central Europe also for other tree species (Howe et al. 2004; Vitasse et al. 2009). As a consequence of these different seasonal growing patterns, northern or high-altitude provenances are prone to late frost events in provenance trials or when moved southwards (Johnsen and Apeland 1988; Hannerz 1994; Hannerz and Westin 2005), an observation also reported for Pinus contorta (Dougl. EX Loud.) (Montwé et al. 2018). The frost hardiness is also built up earlier in the year and to a higher degree (Qamaruddin et al. 1993; Gömöry et al. 2010; Kathke and Bruelheide 2011). Furthermore, high-altitude provenances are more drought resistant than some low-elevation provenances, related to the occurrence of frost and droughtinduced desiccation (Modrzyński and Eriksson 2002; Mayr et al. 2002). In addition, seedlings from high-altitude provenances are more susceptible to heat stress but may be more adapted to oxidative stress (Polle and Rennenberg 1992; Valcu et al. 2008). Crown shape and the other mentioned traits demonstrated clinal variation along climatic gradients in several studies (e.g., Schmidt-Vogt 1977; Chmura 2006; Geburek et al. 2008; Gömöry et al. 2010), which is an indication that these traits are important for the adaptation to climatic conditions (Savolainen et al. 2013).

While clinal variation is a general pattern in plants (Halbritter et al. 2018), the first correlation between molecular genetic markers and climatic gradients in Norway spruce had been reported in the 1970s for isoenzymes (Bergmann 1978; Lundkvist 1979). Nowadays, the markers of choice have changed and also the statistical methods have improved, but the methodological approach is similar. Moreover, several candidate genes mainly involved in the control of phenological processes, cold adaptation, and growth have been identified (e.g., Chen et al. 2012, 2016; Scalfi et al. 2014; Di Pierro et al. 2016, 2017). For the first time, we used morphological crown characteristics observed in natural populations of Norway spruce in an association study with such candidate genes for climatic adaptation. With trees growing under similar climatic conditions, genetic divergence is related to the presumed origin of the material, namely planted lowland and autochthonous high-elevation provenances. We will present association with crown shape traits and differentiation of markers in genes, among others, involved in the circadian clock, stress response, and cold adaptation.

In this study, we tested the following hypotheses: (1) SNPs in candidate genes with known association to climatic clines are also associated with crown shape; (2) SNP variation in candidate genes is similar for crown shape morphotypes across regions indicating general trends for altitudinal adaptation; (3) putative gene functions of identified significant SNPs are related to local adaptation to high altitudes.

\section{Materials and methods}

\section{Plant material}

In total, 765 individual Norway spruce trees from seven stands were genotyped at 44 SNPs. The sampled stands are pure Norway spruce, aged between 90 to 300 years and located at 
altitudes from 770 to $1060 \mathrm{~m}$ above sea level (a.s.l.) in the low mountain range of the Thuringian Forest, the Ore Mountains (Saxony), and the Harz Mountains (Lower-Saxony/SaxonyAnhalt) (Fig. S1). In each region, neighboring pairs of highelevation (HE) type stands with narrow-crowned trees and low-elevation (LE) type stands with broad-crowned trees were selected based on recommendations of the local forest administration and sampled from June to August 2016. The characterization as HE- or LE-type stand is strictly based on the phenotype and the presumed origin of the stands. This presumed stand origin differs, as the HE stands were considered autochthonous based on their old age (Jetschke 2019; Wilhelm 1990; Wegener and Kison 2002; Meyer et al. 2017) with subsequent low impact of plant material translocation (Jansen et al. 2017), historic reports on low utilization in specific stands (Greger 1992), and documentation in the management plans. In contrast, the LE stands are likely of allochthonous origin based on their younger age and their overall crown shape as well as the uniform stand and age structure, with visible planting rows in the field. Original documentation of the origin of the planting material was lost over the decades. In the Thuringian Forest, an additional stand was sampled. The so-called Schlossbergfichte is a relict population of typical high-elevation-type narrow-crowned spruce trees. All stands are growing under comparable climatic conditions at high altitudes of the respective mountain ranges. The following averaged mean multiannual (AMMA) values for specific climate variables were calculated as the mean over all stands based on long-term measurements interpolated and provided by the German Weather Service (DWD). Stands are characterized by an AMMA air temperature of $5.2{ }^{\circ} \mathrm{C}$, length of vegetation period of 185.8 days, number of snow cover days of 128.7 days, wind speed at $20 \mathrm{~m}$ a.s.1. of $56.4 \mathrm{~m} / \mathrm{s}$, and annual precipitation of 1399.9 mm (ESM 2 Table S2) (Caré et al. 2018).

From the available 200 samples per site that were collected from all upper layer trees until the projected sample size was obtained (for details see Caré et al. 2018), a random subset of 115 trees per site was used for SNP genotyping. For the relict population Schlossbergfichte, all 75 samples were genotyped.

\section{Phenotypic assessment}

The phenotypic variability of spruce crown architecture in natural populations originating from different altitudes has been extensively investigated in previous studies. Crown structure and branching pattern vary continuously in natural populations of different origins without clearly defined boundaries. Nevertheless, comparing different provenances, the crowns of lowland spruces are of broad appearance with comb-like branching, and mountainous spruces have a more narrow and slimmer crown and plate-like branching (Priehäusser 1958; Schmidt-Vogt 1977, 1979; Gruber 1989,
1993; Geburek et al. 2008). Visual assessment of the crown architecture in the analyzed stands was performed during the sampling of needle material. Each tree was characterized for its branching pattern of second-order branches, the angle of the first-order branches relative to the stem, and the overall structural appearance of the whole crown. We subdivided the range of possible trait expressions into three categories: the high-elevation mountainous Norway spruce phenotype, an intermediate type, and the lowland phenotype (for details see Caré et al. 2018). The subdivision into classes and usage of 3 classes on a continuous trait were done to minimize scoring errors due to complex trait expression that may also be partially influenced by individual growth dynamics and development. The class for mountainous type (narrow-crowned, platelike branching) or lowland type (broad-crowned, comb-like branching) was only assigned to those trees, which clearly showed these traits. All others are scored as intermediate type.

\section{SNP selection and genotyping}

Based on a study by Heer et al. (2016) in the Bavarian National Forest, we selected SNPs in candidate genes that are supposedly involved in phenological adaptation (Chen et al. 2016), the photoperiod pathway (Chen et al. 2010; Heuertz et al. 2006; Källman et al. 2014), local adaptation for latitudinal environmental change (Chen et al. 2012), and stress response (Ganthaler et al. 2017). Putative protein function was assessed by the best BLAST-hit (Altschul et al. 1997) of the coding sequences (congenie.org) against the Arabidopsis genome (atgenie.org) (Sundell et al. 2015). Further details on the analyzed SNPs can be found in Supplementary Materials 1.

Approximately $50 \mathrm{mg}$ of fresh needle tissue from each individual tree was used for extraction of total DNA. The needles were cut into small pieces, then frozen in liquid nitrogen prior to grounding in a MM300 ball mill (Retsch, Haan, Germany) for $2 \mathrm{~min}$ at $30 \mathrm{~Hz}$. DNA was then extracted using the DNeasy 96 Plant Kit (Qiagen, Hilden, Germany) according to the manufacturer's protocol including the addition of $5 \mathrm{ml}$ of $26 \%$ PVP (polyvinylpyrrolidone) solution to the $90.5 \mathrm{ml}$ lysis buffer to mitigate a high content of polyphenolic compounds. DNA concentration and quality were measured using a NanoDrop 2000 spectrophotometer (Thermo Fisher Scientific, Madison, SD, USA). Samples selected for genotyping had an $\mathrm{OD}^{260}$ to $\mathrm{OD}^{280}$ ratio of at least 1.7 and were diluted to roughly $8 \mathrm{ng} / \mu \mathrm{l}$. Approximately $16 \mathrm{ng}$ of dried DNA per sample was then sent to Agena Bioscience (Hamburg, Germany) for genotyping on the MassARRAY ® system. SNP calling was also done by Agena Bioscience GmbH with SpectroACQUIRE v4.3.145, MassARRAY Caller v3.5.4 and MassARRAY Typer (Analyzer) 4.0.163. SNPs that were monomorphic, failed to amplify, and with unreliable allele calling were 
discarded, resulting in 44 polymorphic and reliable SNPs in 24 genes used for the further analysis.

\section{Statistical analysis}

We used several statistical approaches to detect SNPs putatively involved in the adaptation to high-elevation site conditions. Two implementations of a generalized linear model (GLM), an $F_{\mathrm{ST}}$-outlier test, and a differentiation-based method were used to study association of the SNP loci with the three phenotypic groups of narrow, intermediate, and broadcrowned trees. These groups were treated as grouping factors in differentiation-based and outlier approaches or as fixed effect in linear modelling. All methods were run with the pooled data as well as the regional subsets, including both the HE and LE stands. Data analysis, validation, and visualization were mainly performed in R 3.5.1 (R Core Team 2018), if not stated otherwise. Genes with SNPs showing false discovery rate (FDR)-adjusted significant $q$ values or nominal $p$ values across different methods were considered as either putative important adaptive genes or genes tightly linked to such adaptive loci.

The $F_{\mathrm{ST}}$-outlier method implemented in LOSITAN 1.6 (Antao et al. 2008) was run by estimating the expected neutral $F_{\text {ST }}$ based on supposedly selectively neutral random noncoding genomic simple sequence repeats (gSSR) (Caré et al. 2018), using the stepwise mutation model with 50,000 replications and samples arranged into three groups according to three crown shape categories, respectively. A GLM was fitted in TASSEL 5.0 (Bradbury et al. 2007) with the SNPs being response variables, the crown phenotype the fixed effect, and a $Q$-matrix as covariate. The $Q$-matrix is used to account for population structure, as neglecting a present structure may lead to increase in type I and/or II error rates (Xu and Shete 2005; Excoffier et al. 2009) and lower model quality (Cappa et al. 2013). The $Q$-matrixes were derived from the STRUCTURE 2.3.4. (Pritchard et al. 2000) analysis based on the neutral SSR markers that inferred two $(K=2)$ clusters (Caré et al. 2018). Structure results based on SSR markers displayed as admixture coefficients to the two clusters are shown in Fig. S2. In addition, to study the effect of the covariate on the results, two Q-matrices were used in the GLM, with one representing random admixture proportions to three clusters (1) and the other the three distinct regional clusters (2). The GLM implemented in the R-package "SNPassoc" 1.9-2 (González et al. 2007) was run by using all possible contrasts between the genotypes as follows, with naming of the models in brackets according to the package's documentation. The model evaluates all three SNP genotypes against each other (1, codominant model), one homozygote against both the heterozygote and the alternative homozygote (2, dominant; and 3 , recessive model), both homozygotes against the heterozygote $(4$, overdominance model), and the genotypes ordered based on their frequencies ( $5, \log$-additive model). The best model selection has been based on Akaike information criterion (AIC) (Akaike 1998), where in unclear cases, the model with the lowest $p$ value was used further. As this only occurred for SNPs where the $p$ values of all corresponding fitted models were considerably greater than the significance threshold, no false positive occurred. Further, no change in terms of number and identity of the identified significant SNPs by the FDRadjustment occurred. To detect signatures of selection, we also assessed the complementary compositional differentiation $\delta_{\mathrm{SD}}$ (Gregorius and Roberds 1986) between the crown shape groups separately at each locus. This approach can be applied to the detection of selection (Gillet et al. 2016). Calculations were run in DifferInt (Gillet 2013), giving each group equal weights, and significance was tested by 10,000 permutations.

The multiple testing problem when deciding whether or not to reject the null hypothesis in genome-wide association studies was addressed by using FDR adjustment (Storey 2002; Storey and Tibshirani 2003). Based on the $p$ value distribution of each method and dataset, the $q$ values were calculated in the R-package "qvalue 2.10.1" (Storey et al. 2017). The FDR cutoff level indicating significant $q$ values was set to $q \leq 0.05$.

To determine the occurrence and extent of linkage disequilibrium (LD) between SNPs, the standardized index of association (Agapow and Burt 2001) was computed with the Rpackage "poppr" 2.8.1 (Kamvar et al. 2014). Significance of the LD values in each group was then evaluated by 10,000 permutations.

\section{Results}

Overall SNP genotyping was successful with the exception of 10 samples which failed in the amplification step. Among all 755 trees, the narrow, intermediate, and broad-crowned shaped trees were represented in relatively similar proportions of $32.3 \%, 37.6 \%$, and $30.1 \%$, respectively. Within the Harz and Saxony regions, most trees had intermediate crown shapes: $46.8 \%$ and $53.9 \%$, respectively. Narrow-crowned trees in the Harz Mountains (17.3\%) and broad-crowned trees $(16.1 \%)$ in Saxony were underrepresented. The situation was different in Thuringia, where both narrow- and broadcrowned trees were overrepresented with $44.9 \%$ and $36.4 \%$, respectively (Fig. 1).

A summary of the main results for the detected SNPs is presented in Table 1; the complete results for all SNPs are shown in Table S2. Additional Figures $\mathrm{S} 1-\mathrm{S} 8$ are presented in Supplementary Materials 2. Nominal $p$ values of the differentiation $\delta_{S D}$ are presented in Fig. S3, $p$ values of the GLM association model for Tassel in Fig. 2, and for SNPassoc in Fig. S4. Results of $F_{\mathrm{ST}}$ outlier analyses are presented in Fig. S5. The GLM results ( $p$ values) for different $Q$-matrices as covariate can be found in Figs. S6 and S7. 
crown phenotypes of genotyped Norway spruce trees a) total

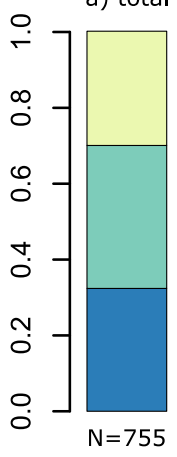

b) by region

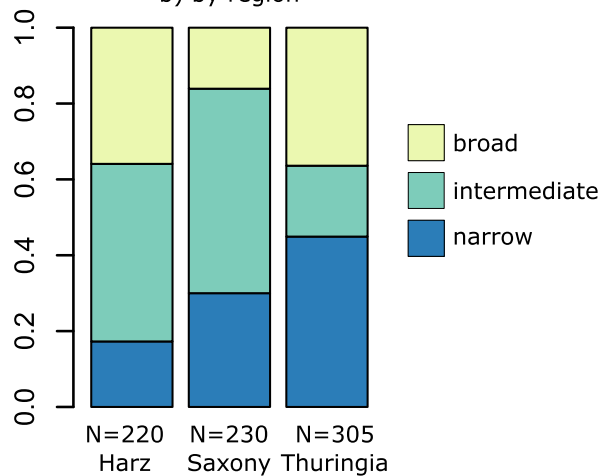

Fig. 1 Frequency of crown phenotypes among a all genotyped Norway spruce trees, and $\mathbf{b}$ within each region. Individuals with failed genotyping are excluded

Population structure had a minor influence on the detection of association in both GLM methods. Nevertheless, not accounting for population structure yielded in some cases only nominal significant results, e.g., MA_605776g0010-849 and PabiesPRR1-240 in the Saxonian dataset, which were clearly below $\alpha=0.05$ when accounting for the neutral population structure based on SSR data (Figs. S4 and S7). Consequently, neutral population structure was considered in all models.

The nominal significant results at $p \leq 0.05$ were obtained for five SNPs (BIF2L2-423, BIF2L2-747, NODE-60-length1132-cov, PabiesPRR1-1992, and PabiesPRR1-3828) located in three genes encoding D6-protein kinase-like 2 (D6PKL2), one gene with unknown function (UF), and pseudo-response regulator 1 (PRR1) or synonymous timing of $\mathrm{CAB}$ extension 1 (TOC1), respectively (Table 1). Corresponding results are presented in Supplementary Materials 3.

Overall, six SNPs were significant after FDR correction for at least one method (Table 1). These SNPs (AP2L3-2313, AP2L3-2842, APL3-2907, GI6-1089, GI6-1207, and MA 39589g0010-566) are located in the three genes: APETALA 2-like (AP2L3), GIGANTEA $(G I)$, and mitochondrial transcription termination factor $(m T E R F)$. Two nonsynonymous SNPs were found in the GI and $m T E R F$ genes. The results for these highly significant genes are described in detail in the following sections.

\section{AP2L3}

Three SNPs in the MA 2193g0020 gene putatively coding for an APETALA 2-like protein were found significant after FDR adjustment by the $\delta_{\mathrm{SD}}$ method ("DifferInt") in the Thuringian dataset (Fig. S3, Table 1). Two out of three SNPs were also found to be nominal significant outliers (Fig. S5, Table 1). At all of these three SNPs within the Thuringian datasets, the major homozygote was most abundant in the group represented by trees with intermediate crown shape
(AP2L3-2319, AP2L3-2842, and AP2L3-2907, with 69.6\%, $100 \%$, and $71.4 \%$, respectively) compared with both other crown shapes (Fig. S7 a-c).

\section{GI}

Both softwares, Tassel and SNPassoc, obtained significant FDR-adjusted $q$-values for the pooled, as well as the Thuringian dataset at both SNPs genotyped in the GI gene MA_19575g0010 using GLM. The highest support in terms of AIC had the overdominance model of the GLM (Fig. S5), indicating frequency differences of homozygotes and heterozygotes between the different crown shape groups. Heterozygous individuals were most abundant in the broadcrowned group and least frequent among narrow-crowned trees (Fig. 3 a, b). Nominal significant differentiation was also found by the $\delta_{\mathrm{SD}}$ method for the Thuringian dataset (Fig. S3, Table 1). The SNP GI6-1089 was non-synonymous causing replacement of the polar, hydrophile asparagine $(\mathrm{N})$ amino acid by the less polar, indifferent to hydrophobic threonine (T) at the protein chain position 657 .

\section{MTERF}

A SNP in the $m T E R F$ gene was significantly associated with crown shape after FDR adjustment in the Thuringian dataset based on both GLM analyses. Accordingly, a nominal significant differentiation was also found by the $\delta_{\mathrm{SD}}$ method for the Thuringian dataset and additionally for the pooled data (Table 1). The allele $\mathrm{T}$ was close to fixation in all datasets. The alternative allele $\mathrm{C}$, only occurring as a heterozygote, was observed in higher proportions in the intermediate and broadshaped trees (Fig. S8 p-r). This SNP is non-synonymous causing replacement of aliphatic, non-polar, hydrophobic isoleucine (I) by the polar and less hydrophobic threonine (T) at position 189 in the protein sequence.

\section{Discussion}

Commonly, association analysis between genetic polymorphisms and climate variables either uses recorded/ interpolated climate data of the sites or elevation and latitude as a proxy for climatic conditions (e.g., Chen et al. 2012; Scalfi et al. 2014; Di Pierro et al. 2017). Here, it is the opposite - morphological characteristics of the trees previously found to be correlated to climatic variables and altitude (Geburek et al. 2008) were used as a proxy for altitudinal adaptation. The relationship between crown shape and altitude and/or occurrence in snow-rich regions is also documented for Germany (Greger 1992; Gruber 1989; Priehäusser 1958) and other regions (Schmidt-Vogt 1977; König 2002). The stands differ in their presumed origin being either locally adapted 
Table 1 Significant associations between SNP loci and crown phenotype based on the generalized linear model (GLM), $F_{\mathrm{ST}}$-outliers, and significant allelic differentiation $\left(\delta_{S D}\right)$ between individuals grouped by their phenotypes, for detected SNPs

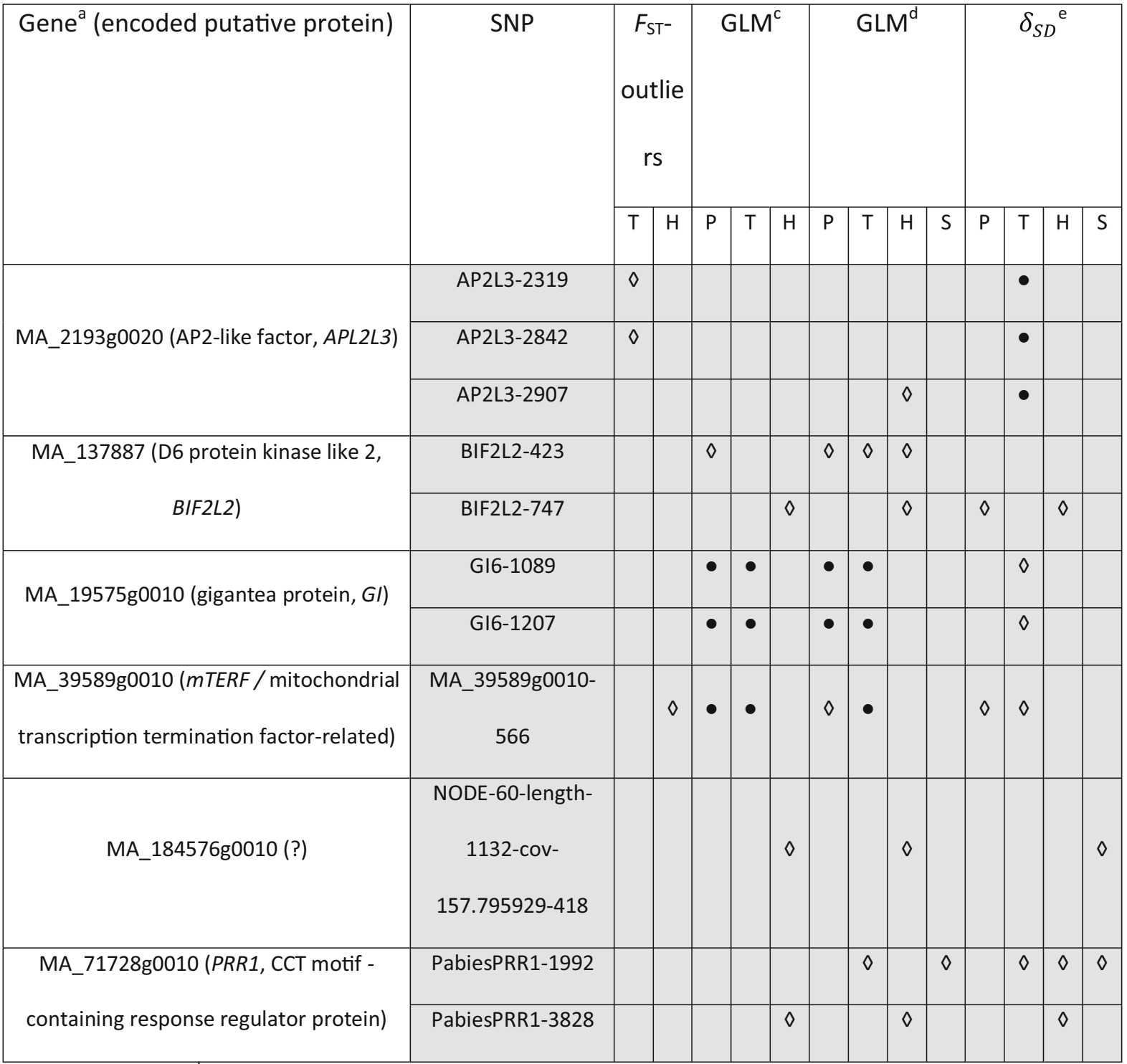

a based on http://congenie.org; ${ }^{b}$ computed using Lositan software (Antao et al. 2008); GLM included neutral population structure with $K=2$ clusters as a

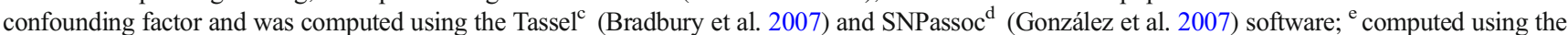
DifferInt (Gillet 2013) software; based on $P$ - pooled, $H$ - Harz, $T$ - Thuringian, and $S$ - Saxonian samples; $\diamond$ and $\bullet$-significant associations or differentiations for nominal $p$-values $\leq 0.05$ or the FDR-adjusted $q$-value $\leq 0.05$, respectively.

autochthonous stands or planted lowland provenances, with crown morphology differing between these presumed provenances.

Selection drivers in the high elevations are among others the short vegetation period, lower temperatures, and snow combined with wind. The autochthonous populations have been subjected to these conditions over several generations, whereas the allochthonous populations are in the presumed first generations encountering these conditions. Different statistical approaches were used to reliably detect candidate SNPs (see also Chen et al. 2014; Wen et al. 2017), as single methods rely on specific model assumptions, which may not be realized in the dataset. The observed genetic differentiation at candidate loci and their association to morphological groups can be interpreted as an effect of the provenance, as stands with contrasting phenotypes grow under similar climatic conditions in each region. In total, six SNPs located in three different genes showed significant associations with crown morphology after FDR correction, which is discussed in detail in the following sections.

\section{AP2L3}

Three genes homologous to the Arabidopsis APETALA2 $(A P 2)$ gene are described also in Norway spruce, namely 


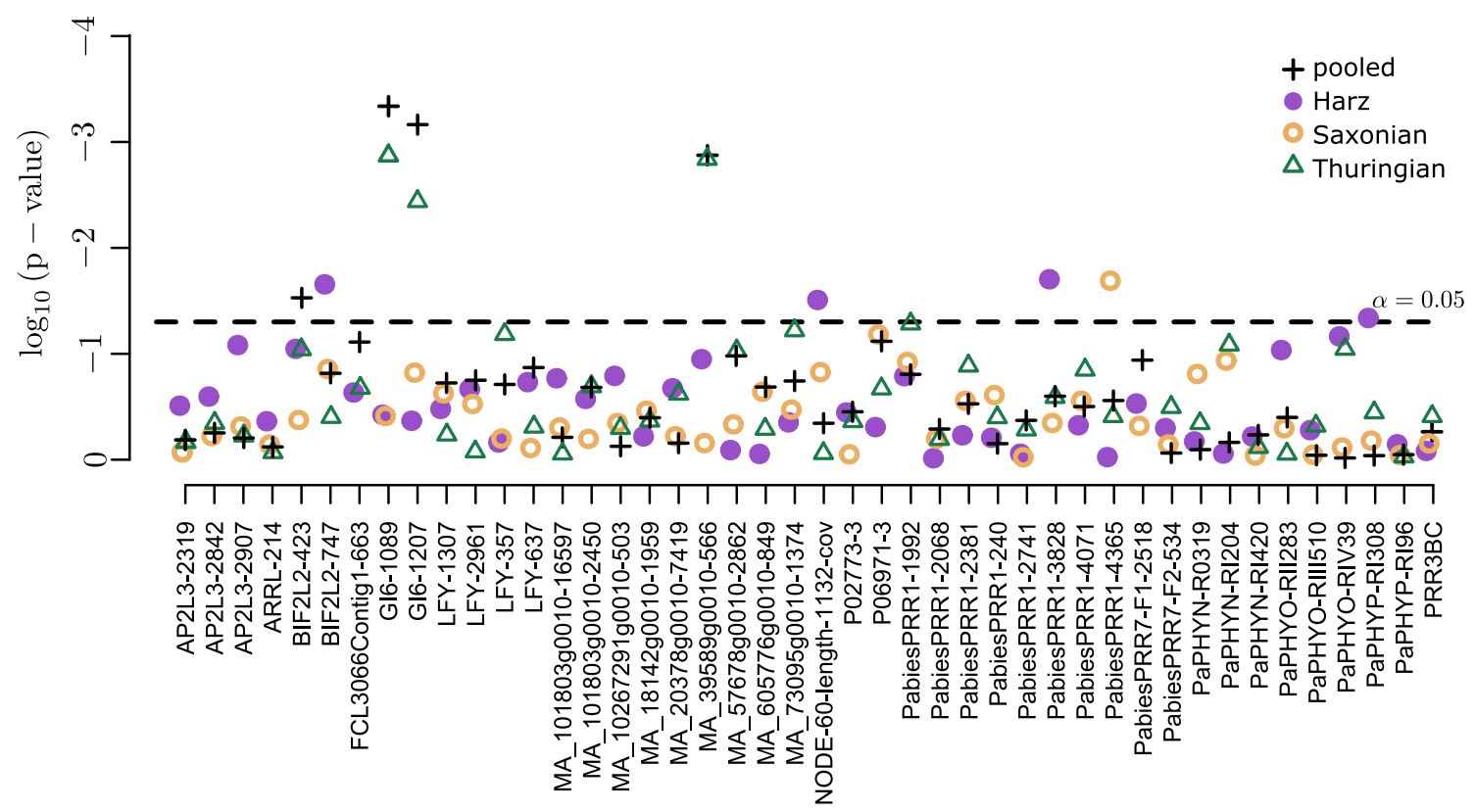

Fig. 2 Nominal $\log _{10}(p)$ values of the association analysis based on GLM analyses implemented in TASSEL 5.0 (Bradbury et al. 2007). Each SNP as a response variable was fitted against the crown phenotype as a fixed effect using the admixture $Q$-matrix (CLUMPAK; Kopelman et al. 2015) as a covariate generated for $K=2$ clusters using the SRUCTURE 2.3.4.

APETALA2 LIKE1 (AP2L1), AP2L2, and AP2L3 (Nilsson et al. 2007) and are functionally conserved among seed plants (Shigyo and Ito 2004; Shigyo et al. 2006; Nilsson et al. 2007). In Arabidopsis, AP2 is involved in the regulation of meristem identity, floral organ specification, seed coat development, flowering time, and the juvenile/adult phase shift (Jofuku et al. 1994, 2005; Weigel 1995). The AP2L3 (MA_2193g0020) gene is, together with AP2L1, differentially expressed in the female cone together regulating differentiation of the ovuliferous scale (Nilsson

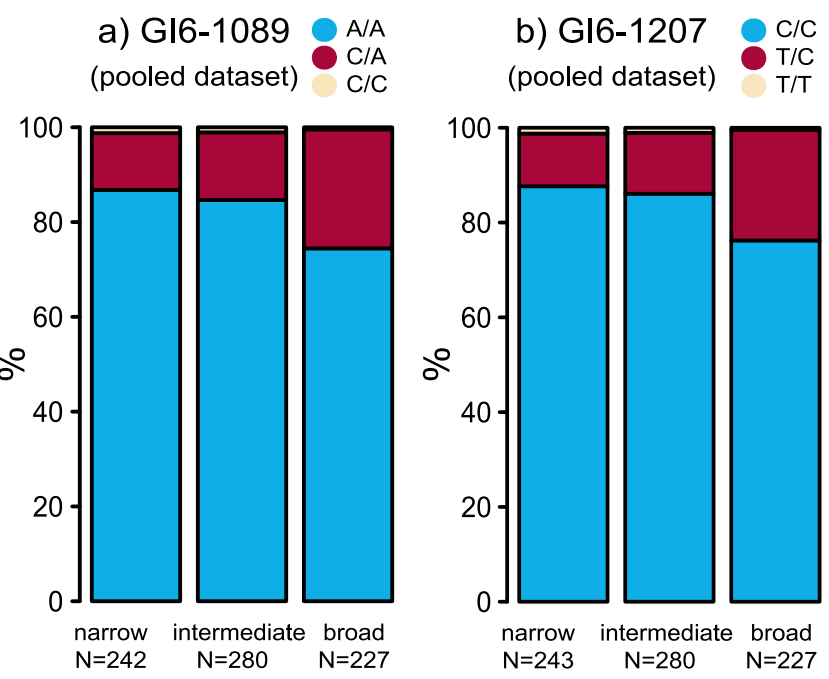

Fig. 3 Frequency of genotypes at the two Gigantea genes SNPs a GI61089 and b GI6-1207 in the three phenotypic groups of main crown trait (narrow, intermediate, and broad) for the pooled dataset. N, sample size
(Pritchard et al. 2000) analysis based on the neutral SSR markers (Caré et al. 2018). The datasets are color-coded as described in the right-hand legend. SNP loci are alphabetically ordered along the $\mathrm{x}$-axis. The dashed line is the threshold equalled $\log _{10}(0.05)$

et al. 2007). Adaptive relevance related to temperature of the AP2 genes was identified also in Picea mariana ([MILL.] B.S.P.) (Prunier et al. 2011) and related to biotic and abiotic stress in Picea glauca ([Moench] Voss) (Namroud et al. 2008). For Norway spruce, Chen et al. (2016) identified three SNPs in AP2L3 by comparing Norway spruce from the Fennoscandian (Baltico-Nordic) domain with those from the Alpine domain. Allele frequencies of SNPs in the AP2L3 gene are closer to fixation in the Fennoscandian domain which can be a result of purifying selection or due to recent postglacial range expansion.

In the present study, three SNPs found in one intron of the AP2L3 gene were differentiated between crown morphology groups only in Thuringia. The higher frequency of the most common allele (C) and lack of $\mathrm{T} / \mathrm{T}$ homozygotes in the intermediate crown type group compared with both other groups were also observed only in this region.

Gl

GI genes are core circadian clock genes associated also with tolerance to drought, salt, low temperature and herbicide resistance, miRNA processing, light signalling, regulation of flowering time, and starch and chlorophyll accumulation (Mishra and Panigrahi 2015). The GI gene of Norway spruce is a homolog to the GI gene in Arabidopsis involved in the evening loop of the circadian clock pathway and is functionally conserved between the two species (Karlgren et al. 2013). 
SNPs found in the circadian clock gene $G I$ of Norway spruce are associated with clinal variation of growth cessation (Chen et al. 2012), which was also confirmed in the related species Picea stichensis ([BONG.] CARRIÈRE) (Holliday et al. 2010) and P. obovata (Chen et al. 2014). In Pinus sylvestris (L.), differential expression patterns in populations from different latitudes point to a role in the synchronism between the circadian rhythm and the environment (Alakärppä et al. 2018). The importance of the gene for the regulation of the seasonally induced growth cessation is also known for angiosperms (Lloret et al. 2018; Ding et al. 2018). Here, the trend of an increased frequency of the major allele and genotype in the narrow-crowned individuals was observed not only in the pooled and Thuringia datasets, but also for both other regions. Such increased frequency of the most common homozygote may be explained by directional selection in favor of this major allele in the narrow-crowned group. The observed distribution pattern between broad and narrow morphotypes is in accordance with the observations that several other SNPs in $G I$ also showed increased major allele frequencies toward higher latitudes (Chen et al. 2012) and in Scandinavian compared with alpine populations (Chen et al. 2016). The welldescribed function of the gene in various species, the repeated SNP genotype patterns across regions, and previous association in P. abies with climatic conditions suggest a vital role of this gene in local adaptation.

\section{mTERF}

The $m T E R F$ gene MA_39589g0010 is a homolog of the mitochondrial transcription termination factor-related ( $m T E R F-$ related) AT2G44020 gene in Arabidopsis, where expression patterns point to a role in senescence and seed germination (Kleine 2012). Functional knowledge about $m T E R F$ genes in plants is relatively scarce, yet an adaptive potential of these genes related to environmental stress was suggested by their contribution to the regulation of organelle gene expression. Further, they might play a role in plant growth in distinct developmental stages and tissues (Kleine 2012; Robles et al. 2012; Quesada 2016).

In our study, only a single SNP was found in the $m T E R F$ related gene with an overall very low minor allele frequency (MAF) occurring only as heterozygotes. These heterozygotes were found to be more frequent in broad-crowned trees. With a MAF below 5\%, this SNP would have often been excluded from association or other analyses to avoid potential genotyping errors resulting in confounding effects. Nevertheless, as our analysis covers a large number of individuals in total and at each site, the allele frequency estimates can be considered robust and thus the results of the association analysis reliable. Further, differences in frequency distributions between phenotypic groups are similar between sites and supported by
FDR-adjusted significant association results, suggesting the transferability of the result to a broader range.

\section{Genetic structures and possible evolutionary forces}

Population structuring of sampled stands was small based on the selectively neutral SSRs (Caré et al. 2018). Accordingly, identification of SNPs associated or not associated with crown shape was only slightly impacted by the population structure used in the GLM models as covariat. Nevertheless, not including or including a random population structure as covariate (confounding factor) led both to higher as well as reduced $p$ values compared with the assumed true structure, confirming the need to include a valid population structure as covariate to avoid type I and II errors. The high per population and region sample sizes allowed for reliable estimates of allele and genotype distributions. As it has been previously pointed out, a large within population sample size is important for obtaining meaningful results (Larsson et al. 2013). This is especially true in the light of very low $F_{\mathrm{ST}}$ values per SNP, as just a slight proportion of the differentiation is related to a single SNP (Kujala and Savolainen 2012). Further, it enables reliable assessment of genotype frequencies at SNPs with low MAF, where small changes in frequency might have adaptive importance as here suggested for the $m T E R F$ gene and also previously reported in other species (Fahrenkrog et al. 2017; De La Torre et al. 2018).

Phenology of high- and low-altitude or northern compared with southern provenances exhibits differences in the timing of bud set, flushing, and flowering as well as in frost hardiness (Modrzyński and Eriksson 2002; Hannerz and Westin 2005; Chmura 2006; Kathke and Bruelheide 2011). Accordingly, we found genetic association of crown shape groups with variation in candidate genes that are involved in regulating these phenological processes. The association of the core circadian clock gene $G I$ and the PRRI gene with crown shape found in this study particularly suggests phenological adaptation toward shortened vegetation period and cold temperatures. The previous studies in angiosperms and gymnosperms also suggested the importance of the core circadian clock in the process of climate adaptation (Mishra and Panigrahi 2015; Yeaman et al. 2016; Lloret et al. 2018). It can be assumed that planted stands have undergone one generation of selection in the mountainous environment. Assuming typical planting schemes, a reduction from $\sim 10,000$ seedlings/ha to $\sim 130-160$ trees/ha could have altered the genetic composition. Ecotypes adapted to a drastically different environment than the one they were planted in can exhibit pronounced diebacks. On the other hand, there is a high chance that only those plants that have at least gradually adapted to the new environment survive (Schmidt-Vogt 1978; Modrzynski 1993). In seedlings, frost is the key selective agent, as susceptible young plants have a lower chance of survival (Westin et al. 2000). By natural selection in favor of more adapted genotypes in the planted stands, genotype distributions may have been shifted, 
resulting in lower levels of genetic differentiation between highand low-elevation provenances at candidate genes. An even more pronounced differentiation at candidate genes may be expected between high-elevation and low-elevation provenances which were not translocated.

We identified genes associated with crown shape that are involved in the timing of growth cessation, flowering, and bud set. Correct timing of seasonal growth patterns, balancing the trade-off between susceptibility to frost and lower growth rate, is crucial for the survival and competitive capacity. In case of the SNPs in PRR 1 and also in $m T E R F$, the putative fitness advantage of narrow morphotypes appears to be attributed to a homozygous variant, possibly affected by directional selection. For both SNPs in GI, the model evaluating both homozygotes against the heterozygote had the highest support, which could be explained by underdominance. Such underdominance in gene-environment associations was also found for cold-hardiness traits in Pseudotsuga menziesii [(MIRB.) Franco] var. menziesii (Eckert et al. 2009), and the maintenance of a possibility of stable polymorphism in case of underdominance has also been shown theoretically (Gregorius and Ziehe 1986). Similarities of genotype frequencies in the abovementioned SNPs were observed across all regions. Such cross-regional patterns of genotype distribution support the assumption that these genes are of importance to environmental adaptation, and that similar forces acted on the same genes in the same direction.

In the present study, we focused on genes regulating or related to growth rhythm. We found associations with the crown morphotype for six SNPs with high support and additional five SNPs with nominal significance. Our results also indicate a possible importance of genes that are involved in auxin transport processes and genes with a still unknown role in high-altitude adaptation. A direct effect of the detected genes on the architecture is in most cases unlikely based on the current knowledge of gene function. The association could be described as indirect, as genes both related to phenology and morphology are subjected to the same directional selection and as such are associated statistically to both traits. An exception could be gene D6PKL2 which is involved in the regulation of auxin transport, as auxin has a direct impact on the growth of plants. Consequently, genes involved in other physiological processes that have previously been shown to be of importance in local adaptation in P. abies (e.g., Chen et al. 2012, 2014; Källman et al. 2014; Lind et al. 2014) or other species (e.g., Namroud et al. 2008; Prunier et al. 2011; Di Pierro et al. 2016, 2017; Yeaman et al. 2016; Roschanski et al. 2016) should be included in future studies related to high-altitude adaptation.

\section{Conclusion}

In this study, we presented evidence of the genetic adaptation to high altitude of narrow-crowned mountainous trees of
P. abies in natural populations. With high statistical support, allele distributions of SNPs in two genes, GI and mTERF, between crown morphology groups suggest directional selection. SNPs in genes with congruent genotype frequencies in the different crown shape groups across regions imply the importance of these genes in local adaptation. For the candidate genes of the circadian clock GI and PRR1/TOC1, which had lower support, the genotype and allele distributions coincide with patterns observed at circadian clock genes in latitudinal clines of this and other species providing additional evidence for the important role of circadian clock genes in local adaptation. The results further point to the importance of crown shape in the practical assessment of tree adaptiveness to mountainous environments, which can help in the identification of seed sources and locally adapted genetic resources.

Acknowledgments The authors thank the Northwest German Forest Research Institute (NW-FVA) for providing the samples of the Brocken (Harz) population with special thanks to Serge Havel for preparation of the samples, Alexandra Dolynska, Christine Radler for assistance with laboratory work, Staatsbetrieb Sachsenforst, ThüringenForst, Niedersächsische Landesforsten, and Forstliches Forschungs- und Kompetenzzentrum (FFK Gotha) for their assistance in stand selection. We also acknowledge the anonymous reviewer for the comments that improved the manuscript.

Data archiving statement SNP data is submitted to Tree Genes database (https:/treegenesdb.org/) and is pending approval before being published under the expected accession number TGDR167.

Funding information This research was funded by the German Federal Ministry of Food and Agriculture (BMEL) represented by the Fachagentur Nachwachsende Rohstoffe e. V. (FNR) grant number FKZ 22023814

\section{Compliance with ethical standards}

Conflict of interest The authors declare that they have no conflict of interest.

\section{References}

Agapow P-M, Burt A (2001) Indices of multilocus linkage disequilibrium. Mol Ecol Notes 1:101-102. https://doi.org/10.1046/j.14718278.2000.00014.x

Akaike H (1998) Information theory and an extension of the maximum likelihood principle. In: Parzen E, Tanabe K, Kitagawa G (eds) Selected papers of Hirotugu Akaike. Springer Series in Statistics (Perspectives in Statistics). Springer, New York. https://doi.org/10. 1007/978-1-4612-1694-0_15

Alakärppä E, Salo HM, Valledor L, Cañal MJ, Häggman H, Vuosku J (2018) Natural variation of DNA methylation and gene expression may determine local adaptations of Scots pine populations. J Exp Bot 69:5293-5305. https://doi.org/10.1093/jxb/ery292

Altschul SF, Madden TL, Schäffer AA, Zhang J, Zhang Z, Miller W, Lipman DJ (1997) Gapped BLAST and PSI-BLAST: a new generation of protein database search programs. Nucleic Acids Res 25: 3389-3402. https://doi.org/10.1093/nar/25.17.3389 
Antao T, Lopes A, Lopes RJ, Beja-Pereira A, Luikart G (2008) LOSITAN: a workbench to detect molecular adaptation based on a Fst-outlier method. BMC Bioinformatics 9:323. https://doi.org/10. 1186/1471-2105-9-323

Apostol EN, Budeanu M (2019) Adaptability of narrow-crowned Norway spruce ideotype (Picea abies (L.) Karst. pendula Form) in 25 years half-sib comparative trials in the Eastern Carpathians. Forests 10:395. https://doi.org/10.3390/f10050395

Beck EH, Heim R, Hansen J (2004) Plant resistance to cold stress: mechanisms and environmental signals triggering frost hardening and dehardening. J Biosci 29:449-459. https://doi.org/10.1007/ BF02712118

Bergmann F (1978) The allelic distribution at an acid phosphatase locus in Norway spruce (Picea abies) along similar climatic gradients. Theor Appl Genet 52:57-64. https://doi.org/10.1007/BF00281317

Bradbury PJ, Zhang Z, Kroon DE, Casstevens TM, Ramdoss Y, Buckler ES (2007) TASSEL: software for association mapping of complex traits in diverse samples. Bioinformatics 23:2633-2635. https://doi. org/10.1093/bioinformatics/btm308

Cappa EP, El-Kassaby YA, Garcia MN, Acuña C, Borralho NM, Grattapaglia D, Poltri SNM (2013) Impacts of population structure and analytical models in genome-wide association studies of complex traits in forest trees: a case study in Eucalyptus globulus. PLoS One 8(11):e81267. https://doi.org/10.1371/journal.pone.0081267

Caré O, Müller M, Vornam B, Höltken AM, Kahlert K, Krutovsky KV, Gailing O, Leinemann L (2018) High morphological differentiation in crown architecture contrasts with low population genetic structure of German Norway spruce stands. Forests 9:752. https://doi.org/10. 3390/ 9120752

Chen J, Källman T, Ma X-F, Zaina G, Morgante M, Lascoux M (2016) Identifying genetic signatures of natural selection using pooled population sequencing in Picea abies. G3: Genes, Genomes. Genetics 6(7):1979-1989. https://doi.org/10.1534/G3.116.028753

Chen J, Källman T, Ma X, Gyllenstrand N, Zaina G, Morgante M, Bousquet J, Eckert A, Wegrzyn J, Neale D, Lagercrantz U, Lascoux M (2012) Disentangling the roles of history and local selection in shaping clinal variation of allele frequencies and gene expression in Norway spruce (Picea abies). Genetics 191:865881. https://doi.org/10.1534/genetics.112.140749

Chen J, Källman T, Gyllenstrand N, Lascoux M (2010) New insights on the speciation history and nucleotide diversity of three boreal spruce species and a Tertiary relict. Heredity 104:3-14. https://doi.org/10. 1038/hdy.2009.88

Chen J, Tsuda Y, Stocks M, Källman T, Xu N, Kärkkäinen K, Huotari T, Semerikov VL, Vendermin GG, Lascoux M (2014) Clinal variation at phenology-related genes in spruce: parallel evolution in FTL2 and Gigantea? Genetics 197:1025-1038. https://doi.org/10.1534/ genetics.114.163063

Chmura DJ (2006) Phenology differs among Norway spruce populations in relation to local variation in altitude of maternal stands in the Beskidy Mountains. New For 32:21-31. https://doi.org/10.1007/ s11056-005-3390-2

De La Torre AR, Puiu D, Crepeau MW, Stevens K, Salzberg SL, Langley CH, Neal DB (2018) Genomic architecture of complex traits in loblolly pine. New Phytol 221:1789-1801. https://doi.org/10.1111/ nph. 15535

Ding J, Böhlenius H, Rühl MG, Chen P, Sane S, Zambrano JA, Zheng B, Eriksson ME, Nilsson O et al (2018) GIGANTEA- like genes control seasonal growth cessation in Populus. New Phytol 218:14911503. https://doi.org/10.1111/nph.15087

Di Pierro EA, Mosca E, Rocchini D, Binelli G, Neale DB, La Porta N (2016) Climate-related adaptive genetic variation and population structure in natural stands of Norway spruce in the South-Eastern Alps. Tree Genet Genomes 12:15-15. https://doi.org/10.1007/ s11295-016-0972-4
Di Pierro EA, Mosca E, González-Martínez SC, Binelli G, Neale DB, La Porta N (2017) Adaptive variation in natural Alpine populations of Norway spruce (Picea abies [L.] Karst) at regional scale: landscape features and altitudinal gradient effects. For Ecol Manag 405:350 359. https://doi.org/10.1016/j.foreco.2017.09.045

Eckert AJ, Bower AD, Wegrzyn JL, Panda B, Jemstad KD, Krutovsky KV, St. Clair B, Neal DB (2009) Association genetics of coastal Douglas fir (Pseudotsuga menziesii var. menziesii, Pinaceae). I. Cold-hardiness related traits. Genetics 182:1289-1302. https://doi. org/10.1534/genetics.109.102350

Excoffier L, Hofer T, Foll M (2009) Detecting loci under selection in a hierarchically structured population. Heredity 103:285-298. https:// doi.org/10.1038/hdy.2009.74

Fahrenkrog AM, Neves LG, Resende MFR, Vazquez AI, de los Campos G, Dervinis C, Sykes R, Davis M, Davenport R, Barbazuk WB, Kirst M (2017) Genome-wide association study reveals putative regulators of bioenergy traits in Populus deltoides. New Phytol 213:799-811. https://doi.org/10.1111/nph.14154

Ganthaler A, Stöggl W, Mayr S, Kranner I, Schüler S, Wischnitzki E, Sehr EM, Fluch S, Trujillo-Moya C (2017) Association genetics of phenolic needle compounds in Norway spruce with variable susceptibility to needle bladder rust. Plant Mol Biol 94:229-251. https:// doi.org/10.1007/s11103-017-0589-5

Geburek T, Robitschek K, Milasowszky N (2008) A tree of many faces: why are there different crown types in Norway spruce (Picea abies [L.] Karst.)? Flora-Morphology, Distribution, Functional Ecology of Plants 203:126-133. https://doi.org/10.1016/j.flora.2007.01.003

George JP, Grabner M, Campelo F, Karanitsch-Ackerl S, Mayer K, Klumpp RT, Schüler S (2019) Intra-specific variation in growth and wood density traits under water-limited conditions: long-term-, short-term-, and sudden responses of four conifer tree species. Sci Total Environ 660:631-643. https://doi.org/10.1016/j.scitotenv. 2018.12.478

Gillet EM (2013) DifferInt : compositional differentiation among populations at three levels of genetic integration. Mol Ecol Resour 13: 953-964. https://doi.org/10.1111/1755-0998.12145

Gillet EM, Ziehe M, Gregorius HR (2016) Detecting differential viability selection between environments by analysis of compositional differentiation at different levels of genetic integration. Silvae Genet 65: 17-29. https://doi.org/10.1515/sg-2016-0013

Gömöry D, Foffová E, Kmet’ J, Longauer R, Romšáková I (2010) Norway Spruce (Picea abies [L.] Karst.) provenance variation in autumn cold hardiness: adaptation or acclimation? Acta Biol Cracov Ser Bot 52:42-49. https://doi.org/10.2478/v10182-0100022-8

González JR, Armengol L, Solé X, Guinó E, Mercader JM, Estivill X, Moreno V (2007) SNPassoc: an R package to perform whole genome association studies. Bioinformatics 23:654-655. https://doi. org/10.1093/bioinformatics/btm025

Greger O (1992) Erfassung von Reliktvorkommen des autochtonen Fichtenvorkommens im Hochharz. Dissertation, Georg-AugustUniversity Göttingen

Gregorius H-R, Roberds JH (1986) Measurement of genetical differentiation among subpopulations. Theor Appl Genet 71:826-834. https:// doi.org/10.1007/BF00276425

Gregorius HR, Ziehe M (1986) The significance of over- and underdominance for the maintenance of genetic polymorphisms. II. Overdominance and instability with random mating. J Theor Biol 118:115-125. https://doi.org/10.1016/S0022-5193(86)80012-1

Gruber F (1993) Verzweigungssystem, Benadelung und Nadelfall der Fichte (Picea abies). ecomed, Landsberg am Lech

Gruber F (1989) Phänotypen der Fichte (Picea abies (L.) Karst.). I. Verzweigungsphänotypen: Genotyp und Modifikation. Allg Forst Jagdztg 160(8):157-165

Gyllenstrand N, Karlgren A, Clapham D, Holm K, Hall A, Gould PD, Källman T, Lgercrantz U (2014) No time for spruce: rapid 
dampening of circadian rhythms in Picea abies (L. Karst). Plant Cell Physiol 55:535-550. https://doi.org/10.1093/pcp/pct199

Halbritter AH, Fior S, Keller I, Billeter R, Edwards PJ, Holderegger R, Karrenberg S, Puless AR, Widmer A, Alexander JM (2018) Trait differentiation and adaptation of plants along elevation gradients. J Evol Biol 31:784-800. https://doi.org/10.1111/jeb.13262

Hannerz M (1994) Predicting the risk of frost occurrence after budburst of Norway spruce in Sweden. Silva Fenn 28(4):234-249. https://doi. org/10.14214/sf.a9175

Hannerz M, Westin J (2005) Autumn frost hardiness in Norway spruce plus tree progeny and trees of the local and transferred provenances in central Sweden. Tree Physiol 25:1181-1186. https://doi.org/10. 1093/treephys/25.9.1181

Heer K, Ullrich KK, Liepelt S, Rensing SA, Zhou J, Ziegenhagen B, Opgenoorth L (2016) Detection of SNPs based on transcriptome sequencing in Norway spruce (Picea abies (L.) Karst). Conserv Genet Resour 8:105-107. https://doi.org/10.1007/s12686-0160520-4

Hertel D, Schöling D (2011) Below-ground response of Norway spruce to climate conditions at Mt. Brocken (Germany)-are-assessment of Central Europe's northernmost treeline. Flora-Morphology, Distribution, Functional Ecology of Plants 206(2):127-135. https://doi.org/10.1016/j.flora.2010.05.001

Heuertz M, De Paoli E, Källman T, Larsson H, Jurman I, Morgante M, Mascoux M, Gyllenstrand N (2006) Multilocus patterns of nucleotide diversity, linkage disequilibrium and demographic history of Norway spruce [Picea abies (L.) Karst]. Genetics 174:2095-2105. https://doi.org/10.1534/genetics.106.065102

Holliday JA, Ritland K, Aitken SN (2010) Widespread, ecologically relevant genetic markers developed from association mapping of climate-related traits in Sitka spruce (Picea sitchensis). New Phytol 188:501-514. https://doi.org/10.1111/j.1469-8137.2010. 03380.x

Howe GT, Aitken SN, Neale DB et al (2004) From genotype to phenotype: unraveling the complexities of cold adaptation in forest trees. Can J Bot 81:1247-1266. https://doi.org/10.1139/b03-141

Jansen S, Konrad H, Geburek T (2017) The extent of historic translocation of Norway spruce forest reproductive material in Europe. Ann For Sci 74(3):56-17. https://doi.org/10.1007/s13595-017-0644-Z

Jetschke G (2019) Oberhofer Schlossberg-Fichten und MethusalemKiefern von Paulinzella: zwei bemerkenswerte Altbestände von Nadelbäumen. ThüringenForst-Anstalt öffentlichen Rechts: Erfurt, Germany, 2019; (accepted). Mitteilungen 37/2019.

Jofuku KD, den Boer BG, Van Montagu M, Okamuro JK (1994) Control of Arabidopsis flower and seed development by the homeotic gene APETALA2. Plant Cell 6:1211-1225. https://doi.org/10.1105/tpc.6. 9.1211

Jofuku KD, Omidyar PK, Gee Z, Okamuro JK (2005) Control of seed mass and seed yield by the floral homeotic gene APETALA2. Proc Natl Acad Sci 102:3117-3122. https://doi.org/10.1073/pnas. 0409893102

Johnsen Ø, Apeland I (1988) Screening early autumn frost hardiness among progenies from Norway spruce seed orchards. Silva Fenn 22(3):203-212. https://doi.org/10.14214/sf.a15510

Kalela A (1937) Zur Synthesse der experimentellen Untersuchungen über Klimarassen der Holzarten. Communications Instituti Forestalis Fenniae, Helsink

Källman T, De Mita S, Larsson H, Gyllenstrand N, Heuertz M, Parducci L, Suyama Y, Lagercrantz U, Lascoux M (2014) Patterns of nucleotide diversity at photoperiod related genes in Norway spruce [Picea abies (L.) Karst.]. PLoS One 9(5): e95306. https://doi.org/10.1371/ journal.pone.0095306

Kamvar ZN, Tabima JF, Grünwald NJ (2014) Poppr : an R package for genetic analysis of populations with clonal, partially clonal, and/or sexual reproduction. PeerJ 2:e281. https://doi.org/10.7717/peerj.281
Kapeller S, Lexer MJ, Geburek T, Hiebl J, Schueler S (2012) Intraspecific variation in climate response of Norway spruce in the eastern Alpine range: selecting appropriate provenances for future climate. For Ecol Manag 271:46-57. https://doi.org/10.1016/j.foreco.2012.01.039

Karlgren A, Gyllenstrand N, Källman T, Lagercrantz U (2013) Conserved function of core clock proteins in the gymnosperm Norway Spruce (Picea abies L. Karst). PLoS One 8. https://doi.org/10.1371/journal. pone. 0060110

Kathke S, Bruelheide H (2011) Differences in frost hardiness of two Norway spruce morphotypes growing at Mt. Brocken, Germany. Flora 206(2):120-126. https://doi.org/10.1016/j.flora.2010.09.007

Kiellander CL (1962) Picea, Abies, Pseudozuga. In: founded by Th Roemer and W. Rudolf edited by H. Kappert and W. Rudorf (ed) Manual of plant breeding vi-breeding of legumes and fruits, viniculture and silviculture, 2nd edn. P. Parey, Berlin, Hamburg, pp 854 873

Kleine T (2012) Arabidopsis thaliana mTERF proteins: evolution and functional classification. Front Plant Sci 3:1-15. https://doi.org/10. 3389/fpls.2012.00233

König A (2002) Growth and snowbreak damage of Norway spruce provenances from Poland under harsh site conditions. In: Meier-Dinkel A, Steiner W (eds) Forest tree breeding in an eco- logically oriented forest management system. Schriften Forstlichen Fakultät Universität Göttingen und der Niedersächsischen Forstlichen Versuchsanstalt, Frankfurt am Main, pp 139-150

Kopelman NM, Mayzel J, Jakobsson M, Rosenberg NA, Mayrose I (2015) Clumpak: a program for identifying clustering modes and packaging population structure inferences across K. Mol Ecol Resour 15:1179-1191. https://doi.org/10.1111/1755-0998.12387

Kujala ST, Savolainen O (2012) Sequence variation patterns along a latitudinal cline in Scots pine (Pinus sylvestris): signs of clinal adaptation? Tree Genet Genomes 8(6):1451-1467. https://doi.org/10. 1007/s11295-012-0532-5

Larsson H, Källman T, Gyllenstrand N, Lascoux M (2013) Distribution of long-range linkage disequilibrium and Tajima's D values in Scandinavian populations of Norway Spruce (Picea abies). G3 Genes, Genomes. Genetics 3(5):795-806. https://doi.org/10.1534/ g3.112.005462

Liesebach M, Rau H, König AO (2010) Fichtenherkunftsversuch von 1962 und IUFRO-Fichtenherkunftsversuch von 1972 - Ergebnisse von mehr als 30-jähriger Beobachtung in Deutschland. Nordwestdeutsche Forstliche Versuchsanstalt (NW-FVA), Göttingen

Lind M, Källman T, Chen J, Ma X-F, Bousquet J, Morgante M, Zaine G, Karlson B, Elfstrand M, Lascoux M, Stenlid J (2014) A Picea abies linkage map based on SNP markers identifies QTLS for four aspects of resistance to Heterobasidion parviporum infection. PLoS One 9(7):e101049. https://doi.org/10.1371/journal.pone.0101049

Lloret A, Badenes ML, Ríos G (2018) Modulation of dormancy and growth responses in reproductive buds of temperate trees. Front Plant Sci 9:1368. https://doi.org/10.3389/fpls.2018.01368

Lundkvist K (1979) Allozyme frequency distributions in four Swedish populations of Norway spruce (Picea abies K.) I. Estimations of genetic variation within and among populations, genetic linkage and a mating system parameter. Hereditas 90:127-143. https://doi. org/10.1111/j.1601-5223.1979.tb01300.x

Mayr S, Wolfschwenger M, Bauer H (2002) Winter-drought induced embolism in Norway spruce (Picea abies) at the Alpine timberline. Physiol Plant 15(1):74-80. https://doi.org/10.1034/j.1399-3054. 2002.1150108.x

Meyer P, Janda P, Mikoláš M, Trotsiuk V, Krumm F, Mrhalová H, Synek M, Lábusová J, Kraus D, Brandes J, Svoboda M (2017) A matter of time: self-regulated tree regeneration in a natural Norway spruce (Picea abies) forest at Mt. Brocken, Germany. Eur J For Res 136: 907-921. https://doi.org/10.1007/s10342-017-1079-7 
Mishra P, Panigrahi KC (2015) GIGANTEA - an emerging story. Front Plant Sci 6:1-15. https://doi.org/10.3389/fpls.2015.00008

Modrzynski J (1993) Altitudinal adaptation of Norway spruce (Picea abies (L.) Karst.) progenies indicates small role of introduced populations in the Karkonosze Mountains. Silvae Genet 44(2-3):70-75

Modrzyński J, Eriksson G (2002) Response of Picea abies populations from elevational transects in the Polish Sudety and Carpathian mountains to simulated drought stress. For Ecol Manag 165:105116. https://doi.org/10.1016/S0378-1127(01)00651-X

Montwé D, Isaac-Renton M, Hamann A, Spiecker H (2018) Cold adaptation recorded in tree rings highlights risks associated with climate change and assisted migration. Nat Commun 9(1):1574. https://doi. org/10.1038/s41467-018-04039-5

Namroud MC, Beaulieu J, Juge N, Laroche J, Bousquet J (2008) Scanning the genome for gene single nucleotide polymorphisms involved in adaptive population differentiation in white spruce. Mol Ecol 17:3599-3613. https://doi.org/10.1111/j.1365-294X. 2008.03840.x

Nilsson L, Carlsbecker A, Sundås-Larsson A, Vahala T (2007) APETALA2 like genes from Picea abies show functional similarities to their Arabidopsis homologues. Planta 225:589-602. https:// doi.org/10.1007/s00425-006-0374-1

Nykänen ML, Broadgate M, Kellomäki S, Peltola H, Quine C et al (1997) Factors affecting snow damage of trees with particular reference to European conditions. Silva Fenn 31:193-213. https://doi.org/10. $14214 /$ sf.a8519

Oleksyn J, Modrzyński J, Tjoelker MG, Zytkowiak R, Reich PB, Karolewski P (1998) Growth and physiology of Picea abies populations from elevational transects: common garden evidence for altitudinal ecotypes and cold adaptation. Funct Ecol 12:573-590. https://doi.org/10.1046/j.1365-2435.1998.00236.x

Polle A, Rennenberg H (1992) Field studies on Norway spruce trees at high altitudes: II. Defence systems against oxidative stress in needles. New Phytol 121:635-642. https://doi.org/10.1111/j.14698137.1992.tb01134.x

Priehäusser G (1958) Die Fichten-Variationen und -Kombinationen des Bayr. Waldes nach phänotypischen Merkmalen mit Bestimmungsschlüssel. Forstw Cent 77:151-171. https://doi.org/ 10.1007/BF01829703

Pritchard JK, Stephens M, Donnelly P (2000) Inference of population structure using multilocus genotype data. Genetics 155:945-959

Prunier J, Laroche J, Beaulieu J, Bousquet J (2011) Scanning the genome for gene SNPs related to climate adaptation and estimating selection at the molecular level in boreal black spruce. Mol Ecol 20:17021716. https://doi.org/10.1111/j.1365-294X.2011.05045.x

QGIS Development Team (n.d.). QGIS geographic information system. Open Source Geospatial Found. Project. Available online: http:// www.qgis.org/

Qamaruddin M, Dormling I, Ekberg I, Erikason G, Tillberg E (1993) Abscisic acid content at defined levels of bud dormancy and frost tolerance in two contrasting populations of Picea abies grown in a phytotron. Physiol Plant 87:203-210. https://doi.org/10.1111/j. 1399-3054.1993.tb00143.x

Quesada V (2016) The roles of mitochondrial transcription termination factors (MTERFs) in plants. Physiol Plant 157:389-399. https://doi. org/10.1111/ppl.12416

R Core Team (2018) R: a language and environment for statistical computing

Robles P, Micol JL, Quesada V (2012) Arabidopsis MDA1, a nuclearencoded protein, functions in chloroplast development and abiotic stress responses. PLoS One 7. https://doi.org/10.1371/journal.pone. 0042924

Roschanski AM, Csilléry K, Liepelt S, Oddou-Muratorio S, Ziegenhagen B, Huard F, Ullrich KK, Postolache D, Vendramin GG, Fady B (2016) Evidence of divergent selection for drought and cold tolerance at landscape and local scales in Abies alba Mill. in the French
Mediterranean Alps. Mol Ecol 25:776-794. https://doi.org/10.1111/ mec. 13516

Savolainen O, Lascoux M, Merilä J (2013) Ecological genomics of local adaptation. Nat Rev Genet 14:807-820. https://doi.org/10.1038/ $\operatorname{nrg} 3522$

Scalfi M, Mosca E, Di Pierro EA, Troggio M, Vendramin GG, Sperisen C, La Porta N, Neal DB (2014) Micro-and macro-geographic scale effect on the molecular imprint of selection and adaptation in Norway spruce. PLoS One 9(12):e115499. https://doi.org/10.1371/ journal.pone.0115499

Schmidt-Vogt H (1978) Monographie der Picea abies (L.) Karst. unter Berücksichtigung genetischer und züchterischer Aspekte. Forstwiss Centralbl 97:281-302. https://doi.org/10.1007/BF02741120

Schmidt-Vogt H (1977) Taxonomie, Verbreitung, Morphologie, Ökologie, Waldgesellschaften. In: Die Fichte -Ein Handbuch in zwei Bänden; vol. 1. Parey, Hamburg; Berlin, p 647

Schmidt-Vogt H (1979) Studien zu morphologischen Variabilität der Fichte (Picea abies (L.) Karst.). Allg Forst- u J-Ztg 142:133-144

Shigyo M, Hasebe M, Ito M (2006) Molecular evolution of the AP2 subfamily. Gene 366:256-265. https://doi.org/10.1016/j.gene. 2005.08.009

Shigyo M, Ito M (2004) Analysis of gymnosperm two-AP2-domaincontaining genes. Dev Genes Evol 214:105-114. https://doi.org/ $10.1007 / \mathrm{s} 00427-004-0385-5$

Skrøppa T, Johnsen Ø (2000) Patterns of adaptive genetic variation in forest tree species; the reproductive enviroment as an evolutionary force in Picea abies. In: Mátyás C (ed) Forest genetics and sustainability. Forestry Sciences, vol 63. Springer, Dordrecht, pp 49-58

Storey JD (2002) A direct approach to false discovery rates. J Roy Stat Soc B 64(3):479-498. https://doi.org/10.1111/1467-9868.00346

Storey JD, Bass AJ, Dabney A, Robinson D (2017) qvalue: Q-value estimation for false discovery rate control. R package version 2.10.1.

Storey JD, Tibshirani R (2003) Statistical significance for genomewide studies. Proc Natl Acad Sci 100:9440-9445. https://doi.org/10. 1073/pnas. 1530509100

Sundell D, Mannapperuma C, Netotea S, Delhomme N, Lin Y-C, Sjödin A, Van de Peer Y, Jansson S, Hvidsten TR, Street NR (2015) The plant genome integrative explorer resource: PlantGenIE.org. New Phytol 208:1149-1156. https://doi.org/10.1111/nph.13557

Sylvén N (1909) Studier öfver granens formrikedom, särskildt dess förgreningstyper och deras skogliga värde. Swedish Institute for Experimental Forestry, Stockholm

Valcu C, Lalanne C, Plomion C, Schlink K (2008) Heat induced changes in protein expression profiles of Norway spruce (Picea abies) ecotypes from different. Proteomics 8(20):4287-4302. https://doi.org/ 10.1002/pmic.200700992

Vitasse Y, Delzon S, Bresson CC, Michalet R, Kremer A (2009) Altitudinal differentiation in growth and phenology among populations of temperate-zone tree species growing in a common garden. Can J For Res 39:1259-1269. https://doi.org/10.1139/x09-054

Wegener U, Kison H (2002) Die Vegetation des Brockens im Nationalpark Hochharz (Exkursion G). Tuexenia 22:243-267

Weigel D (1995) The APETALA2 domain is related to a novel type of DNA binding domain. Plant Cell 7(4):388-389. https://doi.org/10. 1105/tpc.7.4.388

Wen Y-J, Zhang H, Ni Y-L, Huang B, Zhang J, Feng J-Y, Wang S-B, Dunwell JM, Zhang Y-M, Wu R (2017) Methodological implementation of mixed linear models in multi-locus genome-wide association studies. Brief Bioinform 18:906-906. https://doi.org/10.1093/ $\mathrm{bib} / \mathrm{bbx} 028$

Westin J, Sundblad LG, Strand M, Hällgren JE (2000) Phenotypic differences between natural and selected populations of Picea abies. I. Frost hardiness. Scand J Forest Res 15:489-499. https://doi.org/10. 1080/028275800750173393 
Wilhelm B (1990) Die autochtonen Höhenfichten des Thüringer Waldes am Beispiel der Oberhofer Schlosßberg-Fichte. AFZ 33-34:845846

$\mathrm{Xu} \mathrm{H}$, Shete S (2005) Effects of population structure on genetic association studies. BMC Genet 6(Suppl 1):S109. https://doi.org/10.1186/ 1471-2156-6-S1-S109

Yeaman S, Hodgins KA, Lotterhos KE, Suren H, Nadeau S, Degner JC, Nurowski KA, Smets P, Wang T, Gray LK, Liepe KJ, Hamann A,
Holliday JA, Whitlock MC, Rieseberg LH, Aitken SN (2016) Convergent local adaptation to climate in distantly related conifers. Science 353(6306):1431-1433. https://doi.org/10.1126/science. aaf7812

Publisher's note Springer Nature remains neutral with regard to jurisdictional claims in published maps and institutional affiliations. 


\subsection{Chapter II - Supplementary Materials 1: Information on the SNPS}

Available online* or can be requested from the author.

\begin{tabular}{|c|c|c|c|c|c|c|c|c|c|c|c|c|}
\hline SNP & 1] SEQUENCE - & SNPTYPE & SCAFFOLD - & GENEID & PFAM-DES - & GO-DESCR $\square$ & REFERENCE $\mathbf{}=$ & POPLAR GE $=$ & ARABIDOP $\square$ & ARABIDOP $=$ & best Blast $\square$ & Descriptior \\
\hline AP2L3-2319 & TAGATTTCATA & A INTRON & MA_2193 & MA_2193g002 & 2 PF00847-AP2 & GO:0005739- & Chen et al. 20 & Potri.003G1s & ¿AT1G16060 & K K09285-AP2 & AT4G36920.2 & 2 Integrase-tyr \\
\hline AP2L3-2842 & CATTATATGAT & TI INTRON & MA_2193 & MA_2193g002 & 2 PF00847-AP2 & GO:0005739- & Chen et al. 20 & Potri.003G1s & AT1G16060 & KO9285-AP2 & AT4C & rase-tyr \\
\hline AP2L3-2907 & GGAAAAYACC & INTRON & MA_2193 & MA_2193g002 & 2 PF00847-AP2 & GO:0005739- & Chen et al. 20 & Potri.003G1s & \&AT1G16060 & K09285-AP2 & AT4G36920.2 & 2 Integrase-tyr \\
\hline ARRL-214 & TCAATGCGACC & CINTRON & MA_470416 & MA_470416gC & C PF00072-ResF. & & Chen et al. 20 & Potri.002G0 & $\{$ AT1G10470 & K K14492-two & AT1G59940.1 & 1 response reg \\
\hline BIF2L2-423 & TGCAAGTTTAC & CSYN & MA_137887 & MA_137887gC & PF00069-Prot & tGO:0004760-: & Chen et al. 20 & Potri.010G1: & АТТG $12690 /$ & K08286-prot & & 1 D6 protein ki \\
\hline BIF2L2-747 & GGCTTGAGTG & SYN & MA_137887 & MA_137887gC & C PF00069-Prot & $\mathrm{tGO}: 00$ & Chen et al. 20 & Potri. & :AT3G12690 & K08286-prot & & 1D6 \\
\hline FCL3066Conti & ił AAAAAGAAAC & CINTERGENIC & MA_86404 & MA_86404g0C & C PF00673-ribo & & Chen et al. 20 & Potri.002G1: & AT4G01310 & K02931-large & EAT4G01310.1 & 1 Ribosomal LE \\
\hline G16-1089 & GCGGAATCTC & NONSYN & MA_19575 & MA_19575g0C & & GO:0000166- & Chen et al. 20 & Potri.005G15 & ؛AT1G22770 & K12124-GIG/ & & 1 gigantea pro \\
\hline GI6-1207 & GCCTGGCTTG & ; INTERGENIC & MA_19575 & MA_19575g0C & & GO:0000166- & Chen et al. 20 & Potri.005G1S & ؛AT1G22770 & K12124-GIG/ & & 1 gigante \\
\hline LFY-1307 & AAAGaCCTTAT & TINTRON & MA_108198 & MA_108198gC & C PF01698-Flor & GO:0009987- & Chen et al. 20 & Potri.015G10 & (AT5G61850 & & AT5 & nerist, \\
\hline LFY-2961 & AAACGTTGGA & ( SYN & MA_108198 & MA_108198gC & PF01698-Flor & GO:0009987- & Chen et al. 20 & Potri.015G1( & (AT5G61850 & & AT5G61850.1 & 1 floral merist \\
\hline LFY-357 & GTGTTAAGCT & $7 \mathrm{SYN}$ & MA_108198 & MA_108198gC & C PF01698-Flor & GO:00 & Chen e & Potri.015G1C & (AT5G61850 & & AT5G & nerist, \\
\hline LFY-637 & TACTGTTTAGC & CINTRON & MA_108198 & MA_108198gC & C PF01698-Flor & GO:0009987- & Chen et al. 20 & Potri.015G10 & ( AT5G61850 & & AT5 & erist, \\
\hline MA_101803gC & 3C CTAGACAAGTC & CNONSYN & MA_101803 & MA_101803gC & PF00072-Res: & f GO:0004673- & Heer et al. 20: & Potri.003G1: & AT2G01830 / & / K1448 & & $\mathrm{O} \mathrm{CH}$ \\
\hline MA_101803gC & SO GTTCTTCACTC & CNONSYN & MA_101803 & MA_101803gC & C PF00072-Res; & F GO:0004673- & Heer et al. 20: & Potri.003G1: & AT2G01830 & / K14489-arab & 30.1 & $r$ to $\mathrm{CH}$ \\
\hline MA_10267291 & 91 TाGTTACTCT & (SYN & MA_1026729 & 9. MA_10267291 & 1 PF06268-Fasc & & Heer et al. 20: & Potri.005G1f & & & & \\
\hline MA_18142g0C & OCGATGGAAT & TINTRON & MA_18142 & MA_18142g0C & C PF00155-Ami & & Heer et al. 20: & Potri.001G2: & AT2G13360 & K00830-alan & AT2G1 & \\
\hline MA_20378g0C & C CTTGTCAGTAA & ASYN & MA_20378 & MA_20378g0C & 10 PF00063-Myo & & Heer et al. 20 & Potri.013G0 & AT1G04160 / & & AT1G54560.1 & 1 Myos \\
\hline MA_39589g0C & C AGCTTCTGGA & NONSYN & MA_39589 & MA_39589g0C & C PF02536-mTE & $G O: 0000156-$ & Heer et al. 20: & Potri.013G1: & AT2G44020 / & & AT2G44020: & Mitochondri: \\
\hline MA_57678g0C & O TССТTТАСТАA & AIINTRON & MA_57678 & MA_57678g0C & C PF00067-Cyto & GO:0006457- & Heer et al. 20 & Potri.003G1s & & & AT3G14650.1 & 1 cytoc \\
\hline MA_605776gC & 30 AAAGATAGAT & AINTRON & MA_605776 & MA_605776gC & C PF00011-Hsp & & Heer et al. 20: & Potri.012G0 & AT1G52560 / & & AT4 & 1 heat \\
\hline MA_73095g0C & C GGATAGTGGA & A NONSYN & MA_73095 & MA_73095g0C & IC PF00072-ResF & FO:0000155- & Heer et al. 20: & Potri.002G0 & \&AT1G10470 & K14492-two & AT1G59940.1 & 1 response reg \\
\hline NODE-60-leng & g GCCAATCTCCC & CINTERGENIC & MA_184576 & MA_184576gC & & & Chen et al. 20 & & & & & \\
\hline P02773-3 & ARACAAGAGU & $\Lambda$ SYN & MA_18664 & MA_18664g0C & IC PF02309-AUX & & Chen et al. 20 & & & & AT3G16500.: & rome \\
\hline P06971-3 & TTGTGTTATA & SYN & MA_104065 & MA_104065gC & C PF01357-Poll & GO:0005576 & Chen et al. 20 & Potri.008G0 & AT1G12560 / & & AT2C & 1 Barwin-like $\epsilon$ \\
\hline Pabies PRR1-1: & 1: AGCGGATGAT & TNONSYN & MA_71728 & MA_71728g0C & C PF00072-ResF & FGO:0000156- & Heuertz et al. & Potri.015G0t & AT5G61380 & K12127-psel & AT5G61380.1 & $1 \mathrm{CCT}$ motif $-\mathrm{cc}$ \\
\hline Pabies PRR1-2 & 2. NTNNAATACN & ॥ NONSYN & MA_71728 & MA_71728g0C & C PF00072-ResF & F GO:0000156- & Heuertz et al. & Potri.015G0f & AT5G61380 & K1212 & & tif -cc \\
\hline Pabies PRR1-2. & 2. TAYGCTAAAG & ASYN & MA_71728 & MA_71728g0C & C PF00072-ResF & f GO:0000156- & Heuertz et al. & Potri.015G0t & AT5G61380 & K12127-pseı & & otif -cc \\
\hline Pabies PRR1-2. & 2. СTाCTGMTAG & $5 \mathrm{SYN}$ & MA_71728 & MA_71728g0C & C PF00072-Res; & f GO:0000156- & - Heuertz et al. & Potri.015G0 & AT5G61380 & K12127-psel & AT5G61380.1 & 1 CCT motif $-\mathrm{cc}$ \\
\hline Pabies PRR1-2 & 2 TATTATAAGTA & A SYN & MA_71728 & MA_71728g0C & C PF00072-ResF & FO:0000156- & Heuertz et al. & Potri.015G0t & AT5G61380 & K12127 & & tif -cc \\
\hline Pabies PRR1-3: & 3: GTAATGTTTCT & T NONSYN & MA_71728 & MA_71728g0C & C PF00072-Res & f GO:0000156- & Heuertz et al. & Potri.015G0 & AT5G61380 & K12127-pseı & & $1 \mathrm{CCT}$ motif $-\mathrm{cc}$ \\
\hline Pabies PRR1-4। & 4I TTCATGCATTG & 6 NONSYN & MA_71728 & MA_71728g0C & C PF00072-Res; & F GO:0000156- & Heuertz et al. & Potri.015G0 & AT5G61380 & K12127-psel & & $1 \mathrm{CCT}$ motif $-\mathrm{cc}$ \\
\hline Pabies PRR1-4 & 4. ATGATATGGA & NONSYN & MA_71728 & MA_71728g0C & IC PF00072-Res F & FO:0000156- & - Heuertz et al. & Potri.015G0t & AT5G61380 & K12127-psel & AT5G61380.1 & $1 \mathrm{CCT}$ motif $-\mathrm{cc}$ \\
\hline Pabies PRR7-F: & F: ATGCCTTCTGC & GNONSYN & MA_124244 & MA_124244gC & C PF00072-Res: & FO:0000226- & Heuertz et al. & Potri.014G10 & (AT2G46790 / & / K12127-K121 & 10.1 & 1 pseudo-resp \\
\hline Pabies PRR7-F: & F: CAAGAATAACC & CNONSYN & MA_124244 & MA_124244gC & C PF00072-Res; & FO:0000226- & Heuertz et al. & Potri.014G1( & (AT2G46790 / & K K12127-K121 & & 1 pseudo-resp \\
\hline PaPHYN-R031! & $1 !$ TTGTCATGCTC & C SYN & MA_73153 & MA_73153g00 & PF00360-Phyt & GO:0003735- & Heuertz et al. & Potri.008G10 & (AT2G18790 / & / K12120-K121 & & 1 phytochrome \\
\hline PaPHYN-RI204 & S4 CATGGGTTCTR & A SYN & MA_73153 & MA_73153g0C & IC PF00360-Phy1 & 1GO:0003735- & Heuertz et al. & Potri.008G10 & (AT2G18790 / & K K12120-K121 & AT2G18790.1 & 1 phytochrome \\
\hline PaPHYN-RI42C & C GGCTGCTCAG & i NONSYN & MA_73153 & MA_73153g0C & IC PF00360-Phy1 & 1GO:0003735- & Heuertz et al. & Potri.008G1( & (AT2G18790 / & / K12120-K121 & AT2G18790.1 & 1 phytochrome \\
\hline PaPHYO-RII28 & 8 CTGCGATATGC & i SYN & MA_6809 & MA_6809g002 & 2 PF00360-Phy1 & & Heuertz et al. & Potri.008G10 & (AT2G18790 / & K K12120-K121 & & 1 phytochrome \\
\hline PaPHYO-RIII5: & 5: AAATGACTTGA & ASYN & MA_6809 & MA_6809g003 & 13 PF00512-His & GO:0009987- & Heuertz et al. & Potri.008G10 & ( AT2G18790 / & K12120-K121 & AT1G09570.1 & 1 phytochrome \\
\hline PaPHYO-RIV3C & $3 \subseteq \pi$ TIAAACTGCA & A NONSYN & MA_6809 & MA_6809g003 & 13 PF00512-His & GO:0009987 & Heuertz et al. & Potri.008G1( & (AT2G18790 / & / K12120-K121 & AT1G09570.1 & 1 phytochrome \\
\hline PaPHYP-RI308 & 8 CTCGAATTCAA & A NONSYN & MA_1043553! & 31MA_1043553C & CPF00360-Phy1 & 1GO:0000155- & Heuertz et al. & Potri.008G10 & ( AT2G18790 / & K12120-K12] & & chrome \\
\hline PaPHYP-RI96 & NNNNNACCAA & A SYN & MA_1043553I & 3IMA_1043553C & (CPF00360-Phy1 & 1GO:0000155- & Heuertz et al. & Potri.008G1( & (AT2G18790 / & / K12120-K121 & AT2G18790.1 & 1 phytochrome \\
\hline PRR3BC-903 & GCAAAACTCAC & CINTRON & MA_1043713 & 3. MA_10437131 & 1 PF05556-Calc & & Chen et al. 20 & & & & & \\
\hline
\end{tabular}

Description: Table, containing additional information on the SNPs at which the samples in the study where genotyped.

It includes the columns: SNP (name of the SNP), SEQUENCE (up- and downstream genomic sequence with SNP in square brackets), SNPTYPE (position of the SNP; for exon given as type of substitution), SCAFFOUD (ID of the Scaffold containing SNP), GENID (ID of the gene containing the SNP), PFAM-DESCRIPTION (PFAM-ID and description), GO-DESCRIPTION (GO-ID and description), REFERENCE (Reference of the sequence), POPLAR GENE FAMILIY, ARABIDOPSIS GENE FAMILY, ARABIDOPSIS KO, best Blast hit atgeni.org, Description of best Blast hit atgeni.org

*https://static-content.springer.com/esm/art\%3A10.1007\%2Fs11295-019-1394-x/MediaObjects/ 11295_2019_1394_MOESM1_ESM.xlsx 


\subsection{Chapter II - Supplementary Materials 2: Figures and tables}

\section{Crown morphology in Norway spruce (Picea abies [Karst.] L.) as}

\section{adaptation to mountainous environments is associated with single} nucleotide polymorphisms (SNPs) in genes regulating seasonal growth rhythm

published in: Tree Genetics and Genomes

Oliver Caré, Oliver Gailing, Markus Müller, Konstantin V. Krutovsky and Ludger Leinemann

corresponding author: Oliver Gailing, Department of Forest Genetics and Forest Tree Breeding, BüsgenInstitute, Faculty of Forest Sciences and Forest Ecology, Georg-August University of Göttingen, 37077 Göttingen, Germany, e-mail: ogailin@gwdg.de; phone: +49-551-3933536



Figure S1 Map section of central to south-eastern Germany indicating the stand locations as coloured points with corresponding abbreviations as high elevation type $(\mathrm{HE})$, low elevation type (LE), "Schlossbergfichte" (SBF) followed by region Harz Mountains $(H)$, Thuringian Forest $(T)$ and Ore Mountains/ Saxony (S). Longitudinal and latitudinal coordinates (WGS 84; EPSG:4326) are given. Maps generated with QGIS 2.18.15 (QGIS Development Team) using geodata from www.openstreetmaps.org (OpenStreetMap contributors). 


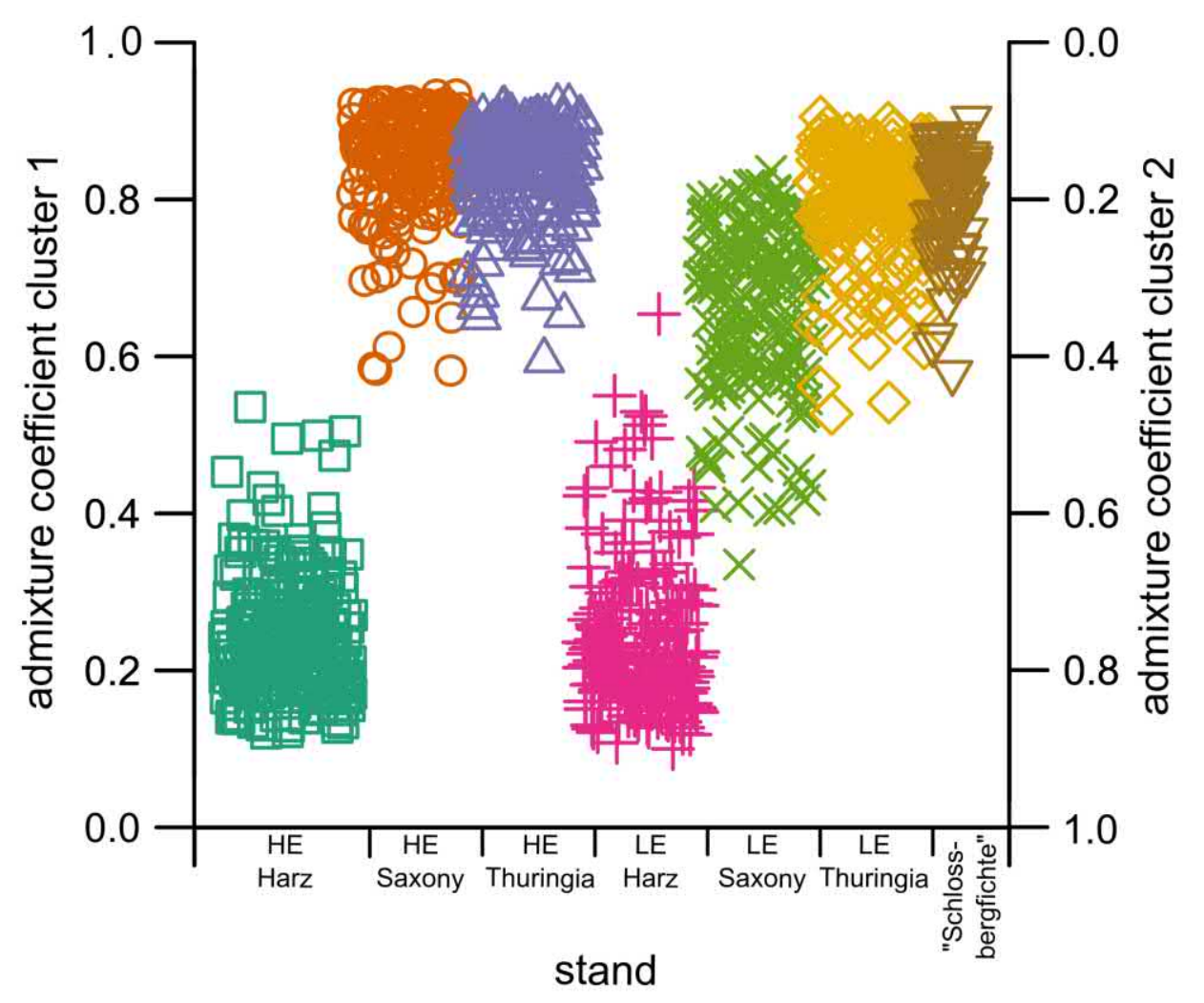

Figure S2 Clustering result based on the STRUCTURE (Pritchard et al. 2000) analysis of 11 SSR markers. Displayed are the averaged (by CLUMPAK (Kopelman et al. 2015)) individual admixture coefficients to cluster 1 and 2 on the primary and secondary $y$ - axis, respectively. Individuals are sorted by their stand membership as indicated on the $x$-axis and by the shape and colour of the points representing the individuals. 


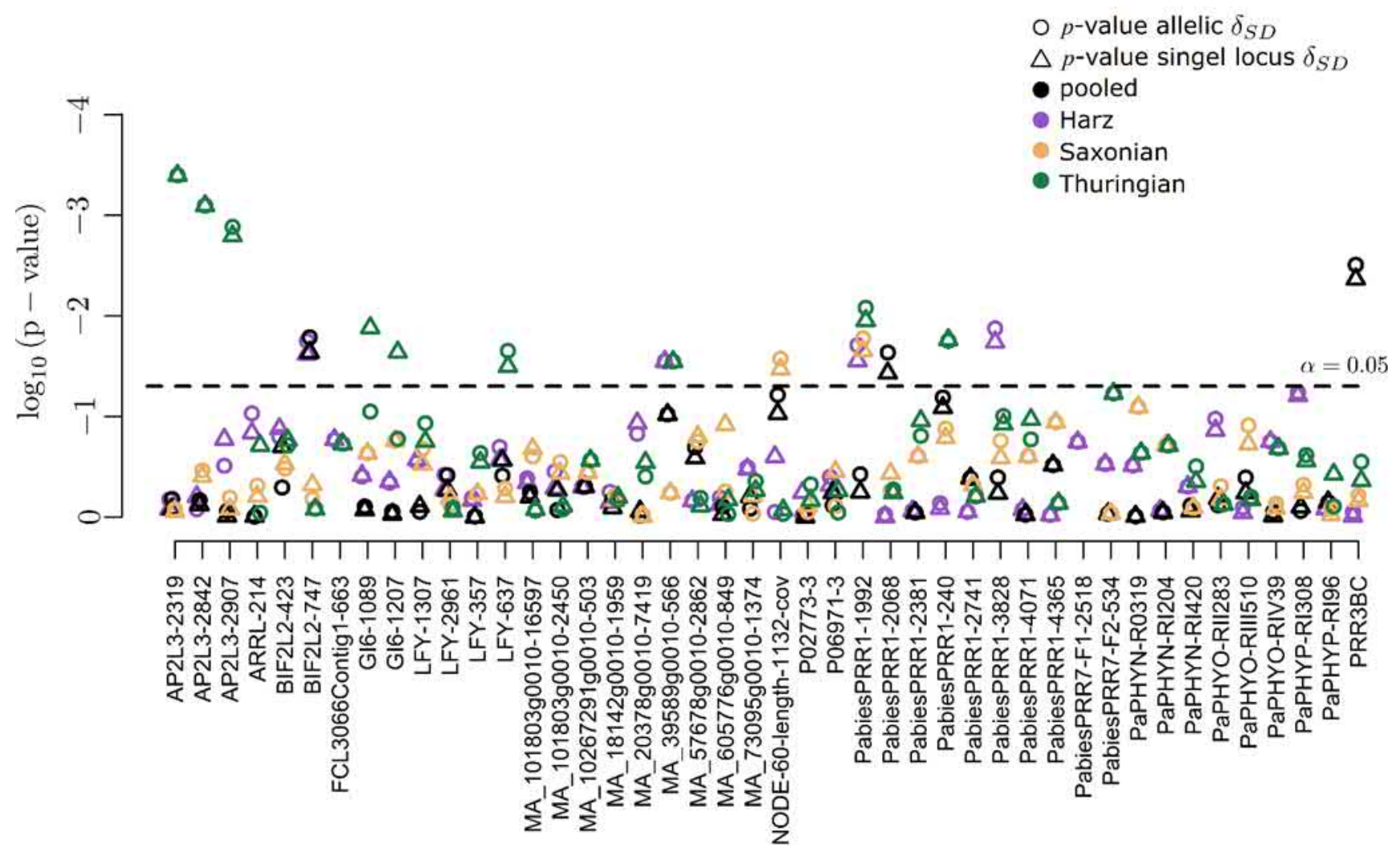

Figure S3 Nominal $p$-values of allelic and genotypic complementary compositional differentiation $\delta_{S D}$ calculated using Differlnt (Gillet 2013) between phenotypic groups of narrow, intermediate and broad shaped trees. Data are presented for each SNP alphabetically ordered along the $\mathrm{x}$-axis with corresponding logarithmic $p$-values on the $y$-axis. The shape of the datapoints corresponds to the $p$-value of allelic (circle) and genotypic differentiation (triangle) between groups for four colour-coded datasets Harz, Saxonian, Thuringian, and pooled. All data points on or above the dashed line indicate significant differentiation at $\alpha=0.05$. 


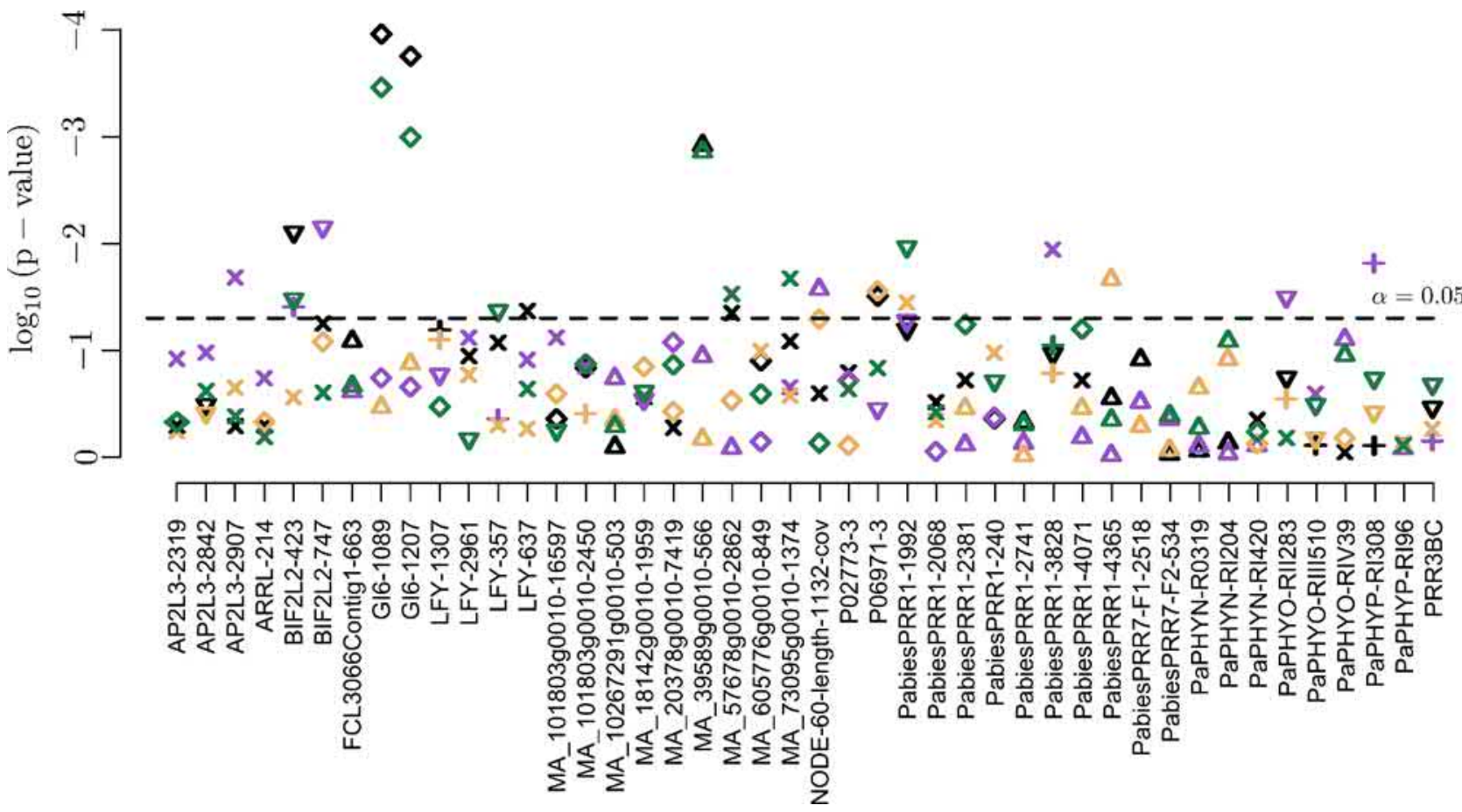

model:

$\nabla$ codominant

+ dominant

$x$ recessive

$\diamond$ overdominant

$\boldsymbol{\nabla}$ log-additive

data:

- pooled

- Harz

- Saxonian

- Thuringian

Figure S4 Nominal $p$-values of the association analysis based on the GLM implemented in the R-package "SNPassoc" 1.9-2 (Gonzalez et al. 2007) for each SNP alphabetically ordered along the $\mathrm{x}$-axis with corresponding logarithmic $p$-values on the $y$-axis for four colour-coded datasets - Harz, Saxonian, Thuringian, and pooled. Each SNP was fitted as a response variable against the crown phenotype as a fixed effect and using $Q$-matrix (CLUMPAK; Kopelman et al. 2015) for population structure representing two clusters $(K=2)$ as a confounding factor calculated using the SRUCTURE 2.3.4 software (Pritchard et al. 2000) based on the neutral SSR markers (Caré et al. 2018). The shape of the data points indicates the most favourable model based on $\triangle \mathrm{AIC}$ or lowest $p$-value. The $y$-axis represents the $\log _{10}$-transformed $p$-values, where for each SNP only the $p$-value obtained by a model with the highest AIC, or in case of ambiguity the lowest $p$-value, is displayed. The dashed line represents the threshold of the $\log _{10}$-transformed nominal $p$ value at $\alpha=0.05$. 


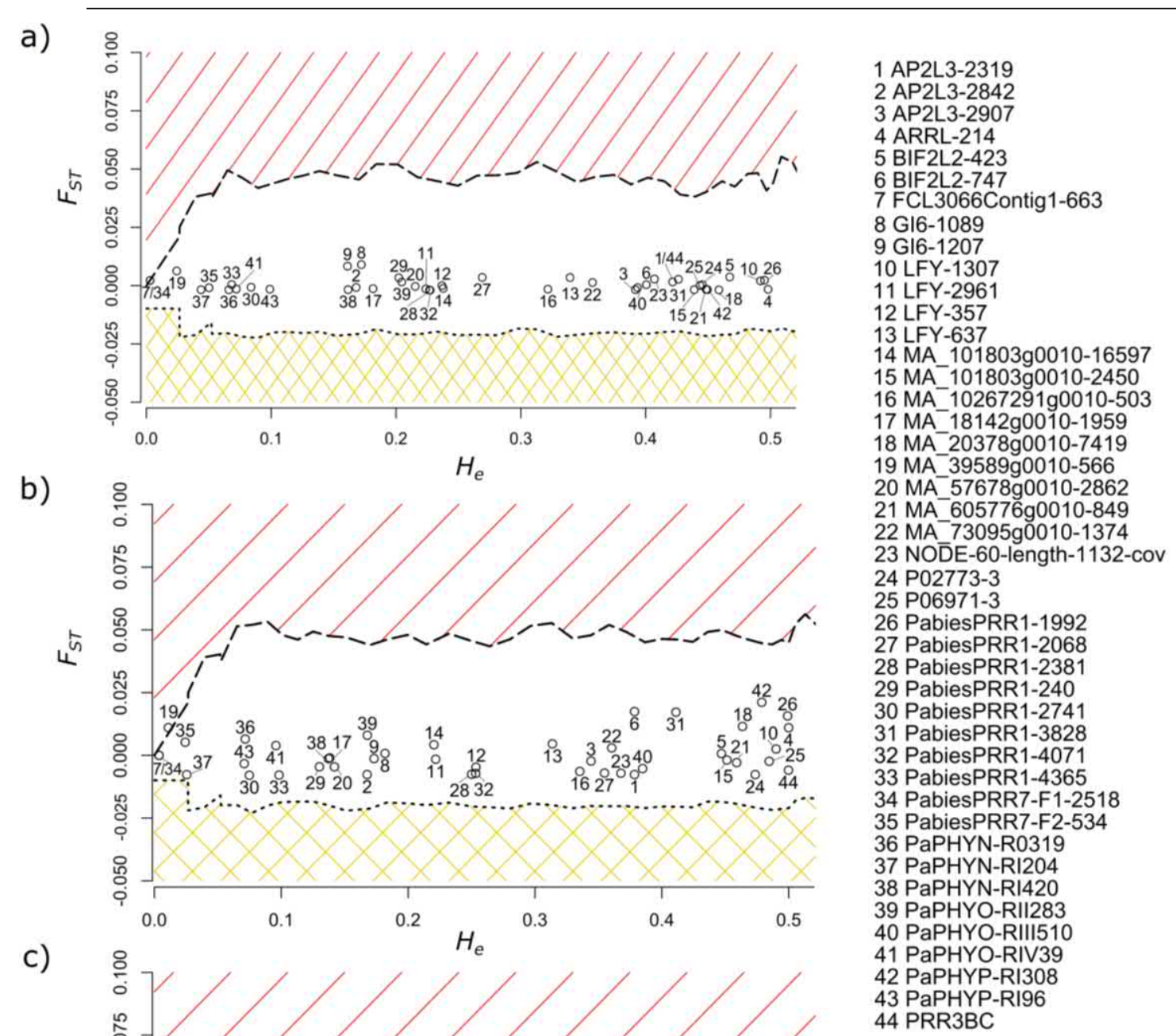

Figure S5 The outlier SNPs detected by LOSITAN (Antao et al. 2008) for the groups of narrow, intermediate and broad crowned trees. Data points correspond to the $F_{\mathrm{ST}}$ and $H_{\mathrm{e}}$ values of SNPs among groups in the (a) pooled, (b) Harz, (c) Saxonian, and (d) Thuringian datasets. SNPs are numbered alphabetically as indicted in the right-hand legend. Black dashed and dotted lines indicate the upper and lower 95\% confidence limits, respectively, both calculated using 50,000 permutations with the stepwise mutation model and the assumed neutral $F_{\text {ST }}$ calculated using SSR markers (Caré et al. 2018). 


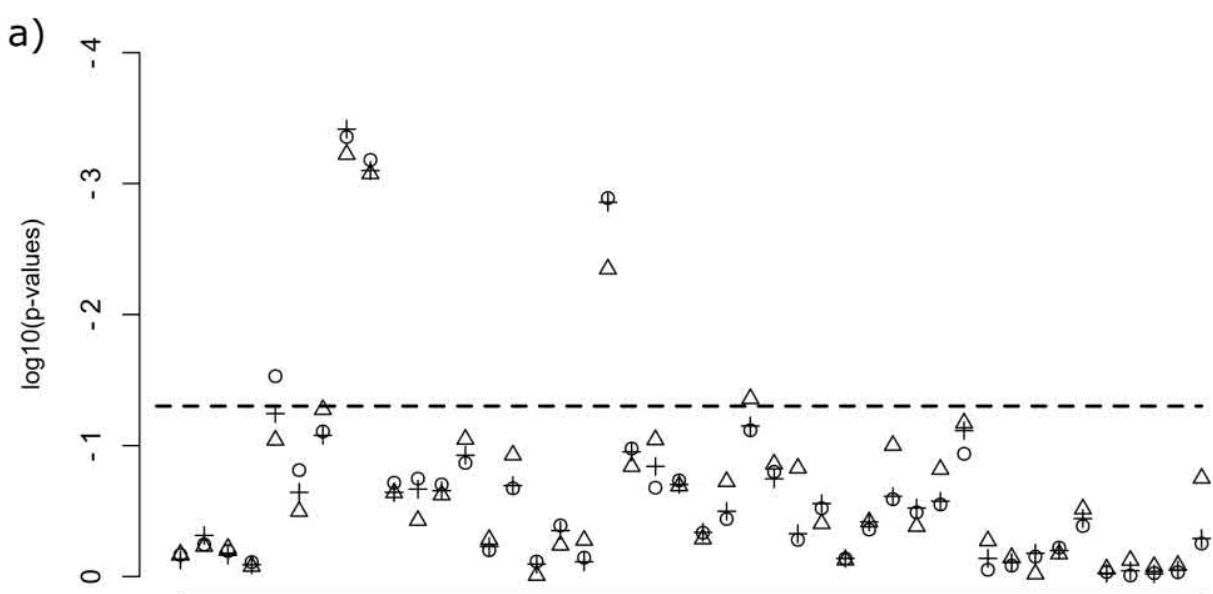

b)

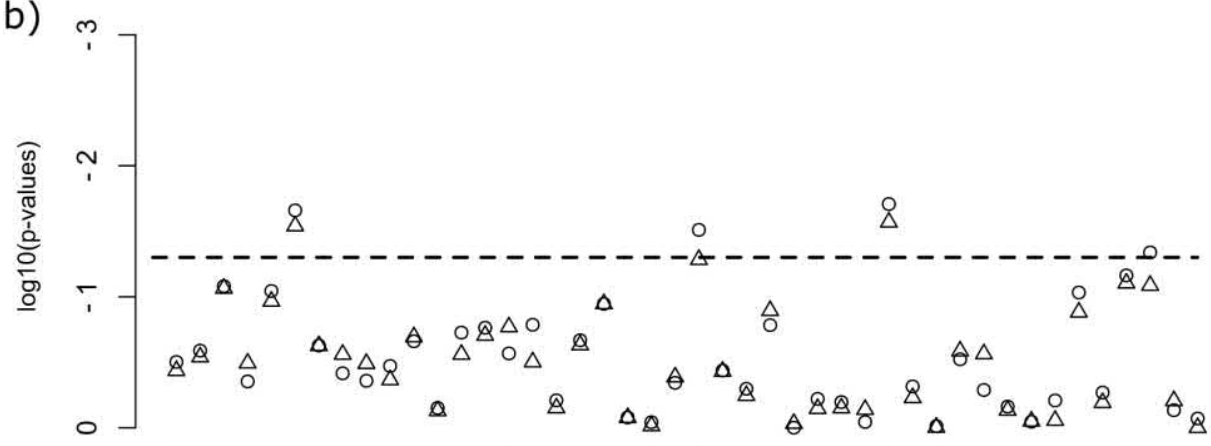

c)
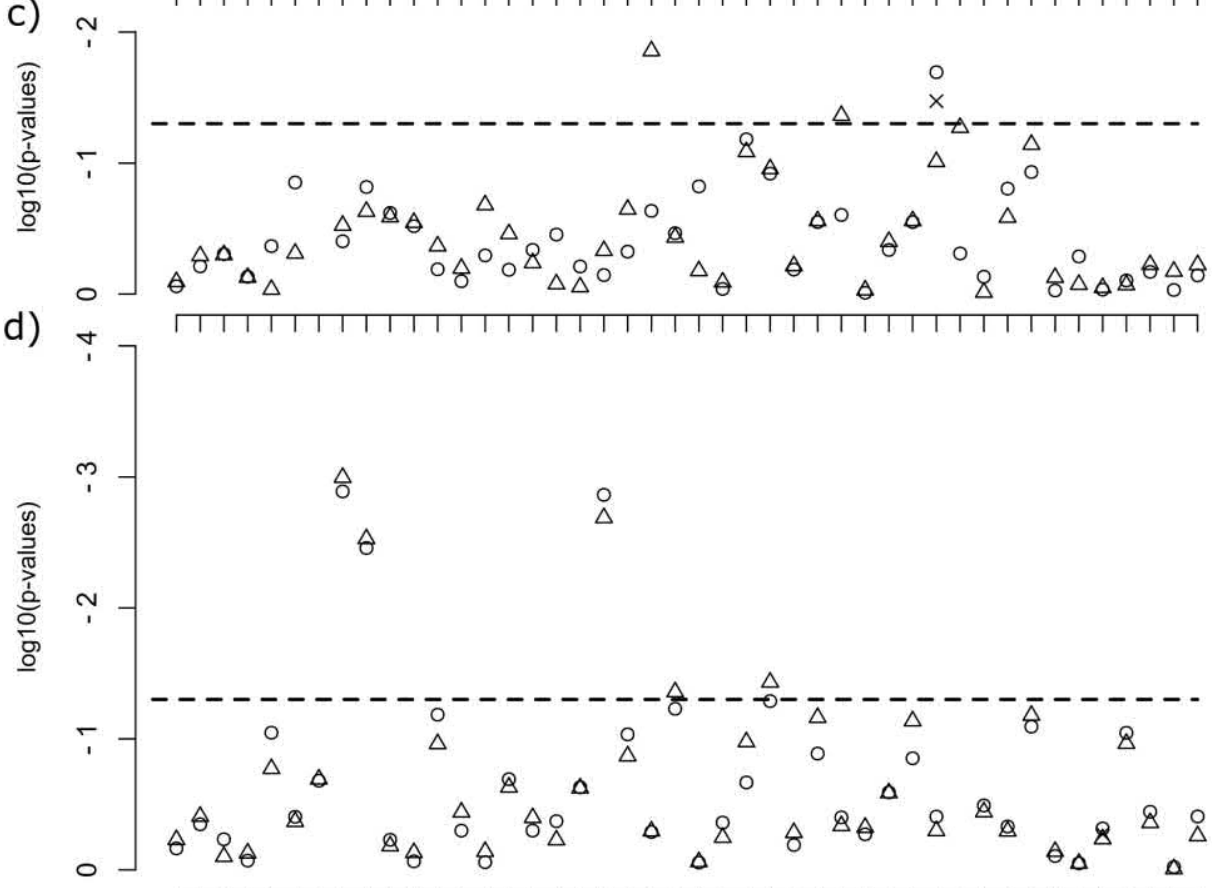

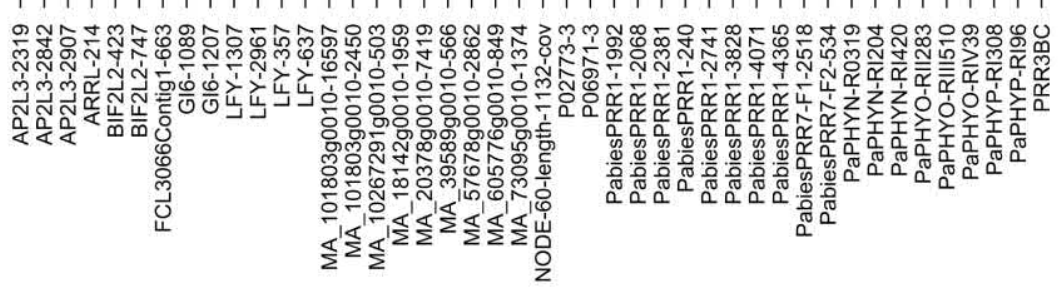

ㅇ $\mathrm{K}=2$

+ Regions

$\Delta$ random_K=3

Figure $\mathbf{S} 6$ Nominal $p$-values of the association analysis based on the GLM implemented in TASSEL 5.0 (Bradbury et al. 2007) for the (a) pooled, (b) Harz, (c) Saxonian and (d) Thuringian datasets for each SNP alphabetically ordered along the $x$-axis with corresponding $p$-values on the $y$-axis. Each SNP was set as a response variable and the phenotype (narrow, intermediate and broad crowned trees) as a fixed effect. The shape of the data points corresponds to the type of the $Q$-matrix used as covariates, where circles indicate the $Q$-matrix (CLUMPAK; Kopelman et al. 2015) for two clusters ( $K=2)$ obtained using the SRUCTURE 2.3.4 software (Pritchard et al. 2000) based on the neutral SSR markers (Caré et al. 2018), crosses indicate that the region of origin and triangles that a randomly generated Qmatrix with three clusters were used. The $y$-axis represents the $\log _{10^{-}}$ transformed $p$-values. The dashed lines are the threshold of the $\log _{10}$ transformed nominal $p$-value at $\alpha=0.05$. 

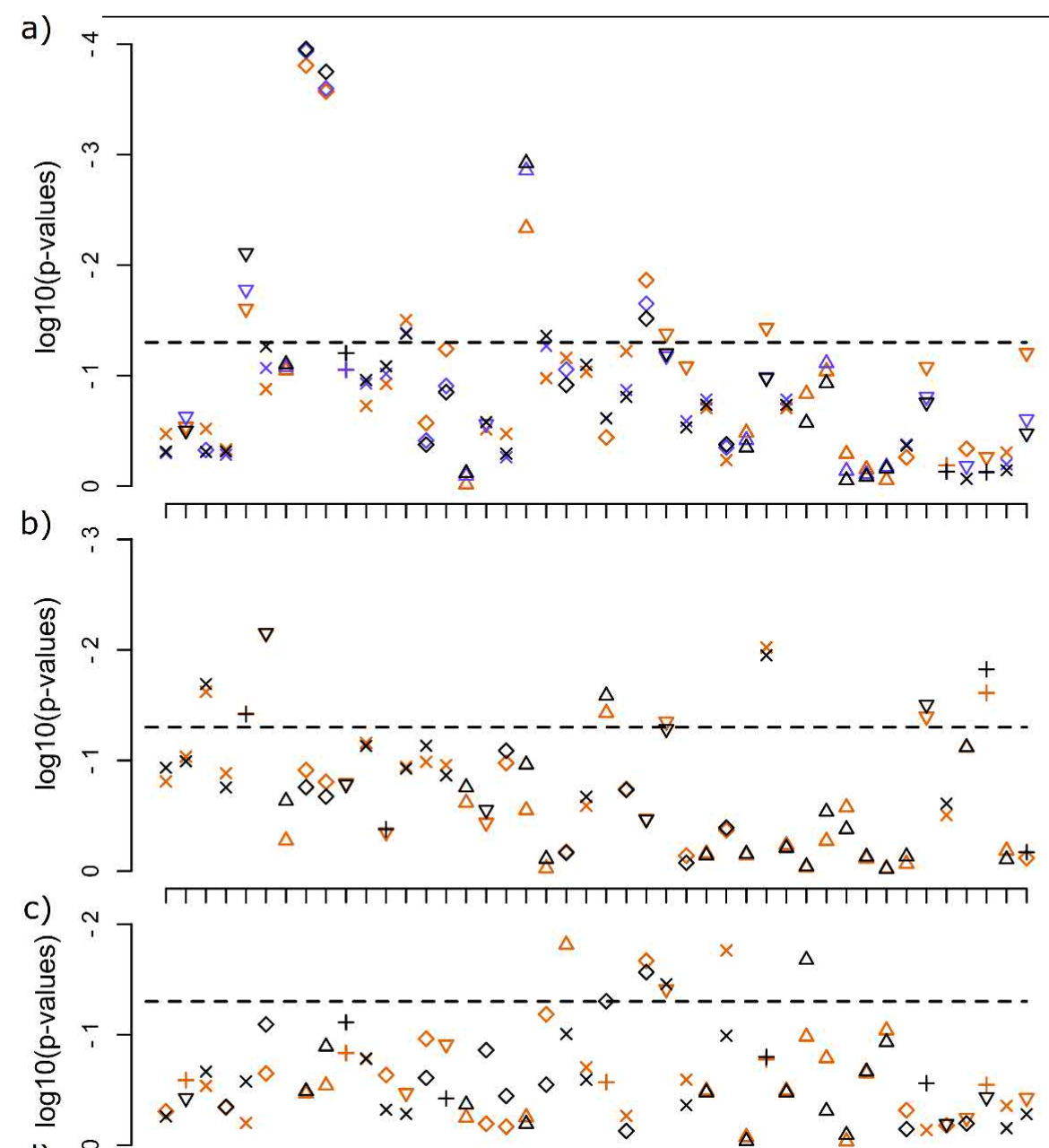

d) $\sigma_{0}$ ता|ा|ा|ा|ा|ा|ा|ा|ा|ा|ा|ा|ा|ा|ा|ा|ा|ा|ा|ा

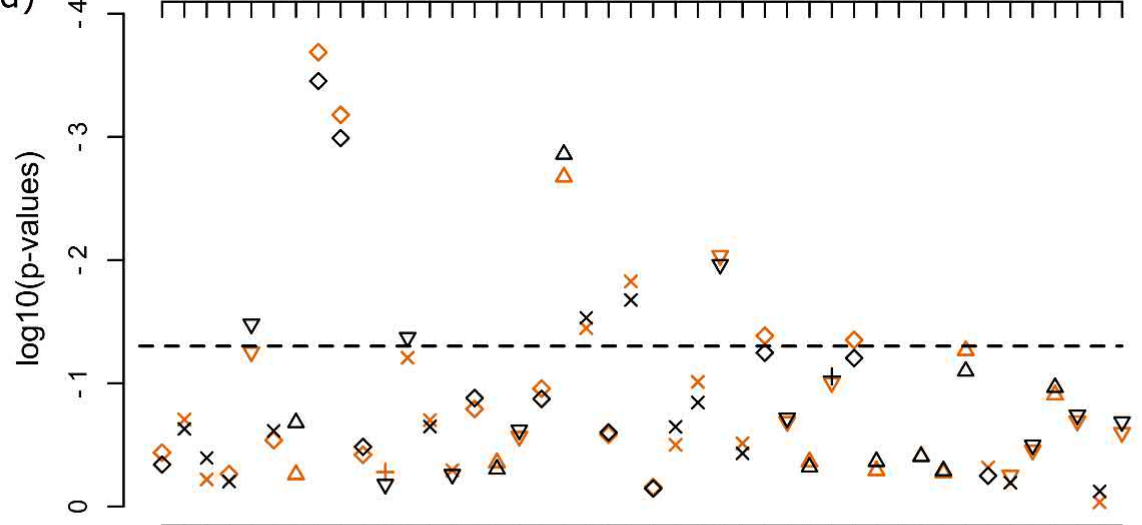

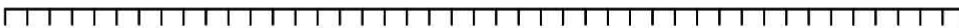

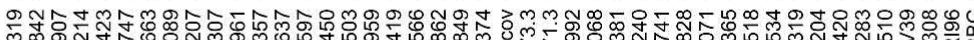
Nल

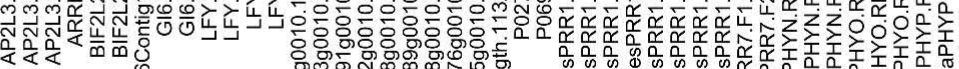
$\triangle$ codominat
+ dominant
$\times$ recessive
$\diamond$ overdominant
$\nabla \quad$ log-additive
$\boxplus$ noK
$\boxplus$ region
田 $\mathrm{K}=2$

Figure S7 Nominal $p$-values of the association analysis based on the GLM implemented in the R-package "SNPassoc" 1.9-2 (Gonzalez et al. 2007) for the (a) pooled, (b) Harz, (c) Saxonian and (d) Thuringian datasets for each SNP alphabetically ordered along the $\mathrm{x}$-axis with corresponding $p$ values on the $y$-axis. Each SNP was set as a response variable and the phenotype (narrow, intermediate and broad crowned trees) as a fixed effect. The colour of the data points corresponds to the $Q$-matrix as covariate, where orange (noK) indicates that no Q-matrix was used, purple (region) that the region of origin was used, and the black $(K=2)$ that the Q-matrix (CLUMPAK; Kopelman et al. 2015) for two clusters obtained by the SRUCTURE 2.3.4 software (Pritchard et al. 2000) based on the neutral SSR markers (Caré et al. 2018) was used. The shape of the data points indicates the most favourable model based on $\triangle \mathrm{AIC}$ or lowest $p$-value. The $y$-axis represents the $\log _{10}$-transformed $p$-values, where for each SNP-loci only the model with the highest AIC, or in case of ambiguity the lowest $p$-value, is presented. The dashed lines are the threshold of the $\log _{10}$-transformed nominal $p$-value at $\alpha=0.05$. 

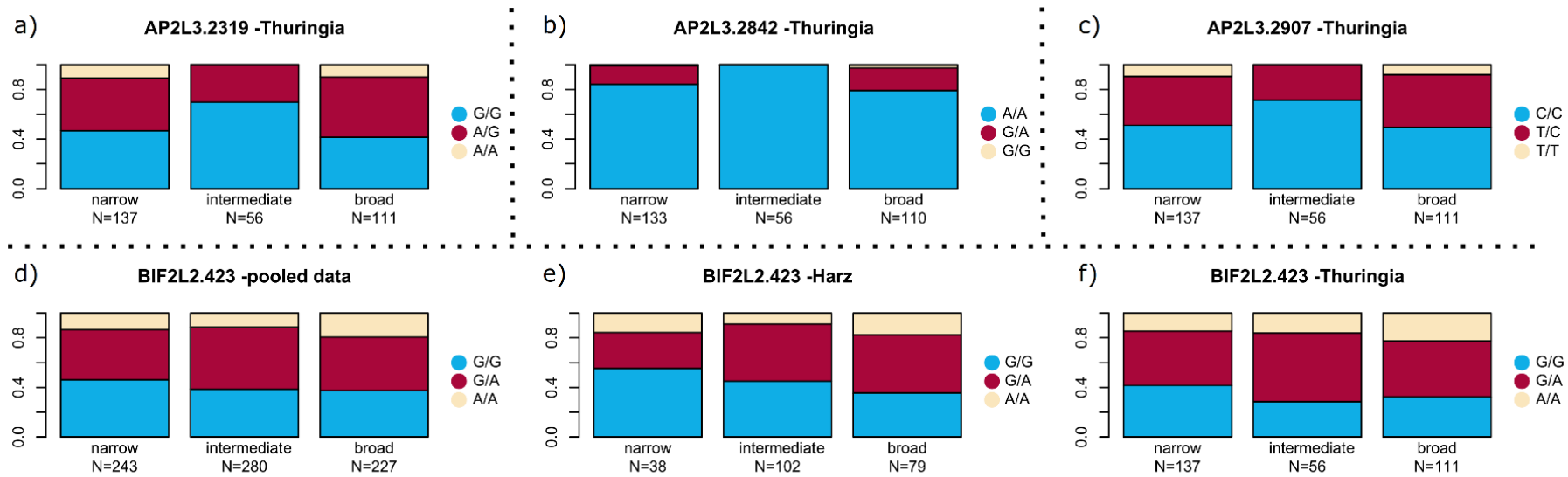

e) BIF2L2.423 - Harz

f) BIF2L2.423 -Thuringia
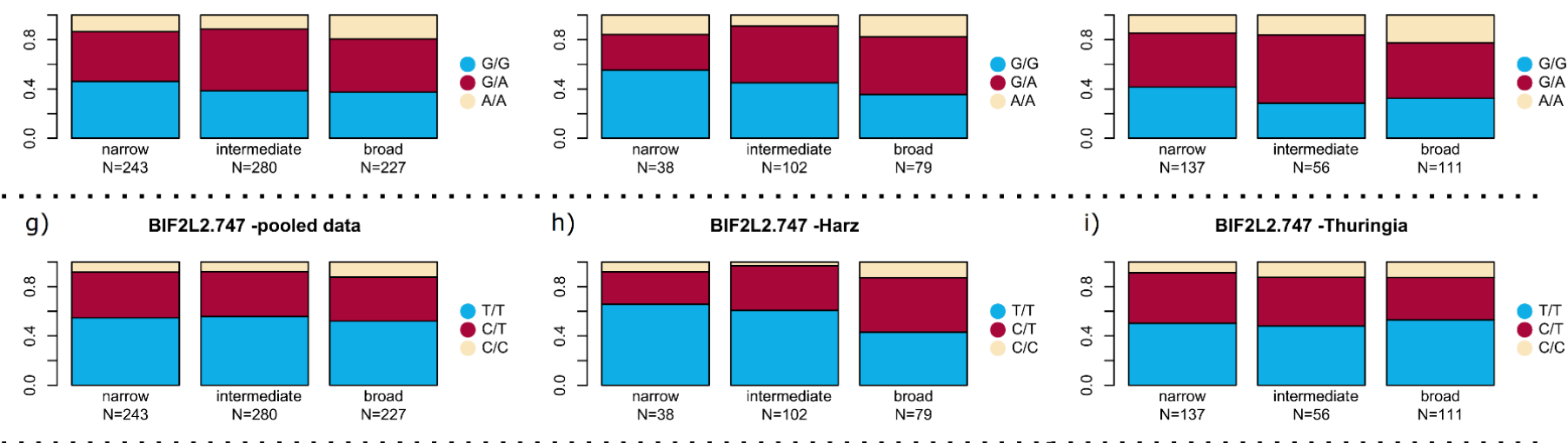

h)

BIF2L2.747 - Harz

BIF2L2.747 -Thuringia

j) NODE.60.length.1132.cov - Harz
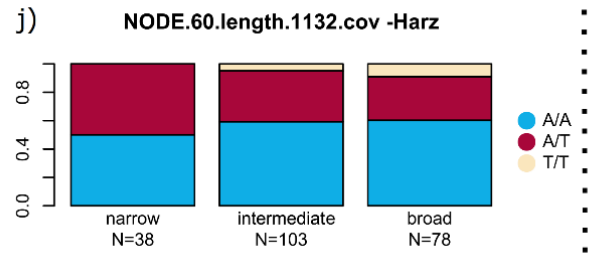

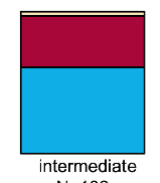

$\mathrm{N}=102$

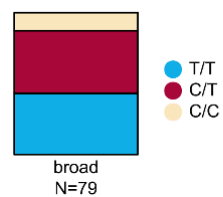

i)

l) Gl6.1089 -pooled data
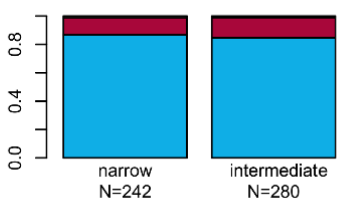

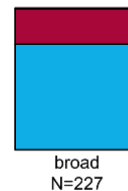

GI6.1089 -Thuringia

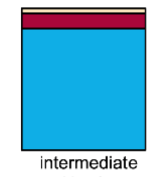

$\mathrm{N}=56$ m)

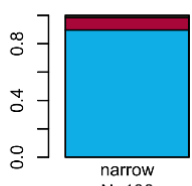

$N=136$

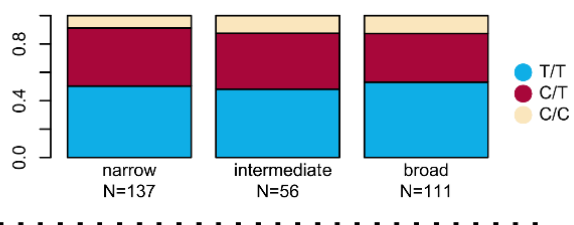

n)

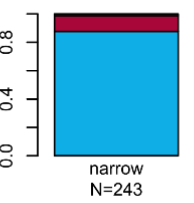

GI6.1207 -pooled data
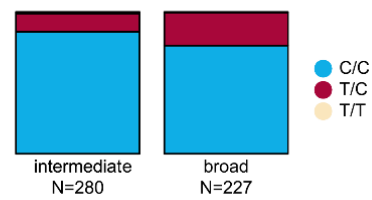

o)

G16.1207 -Thuringia
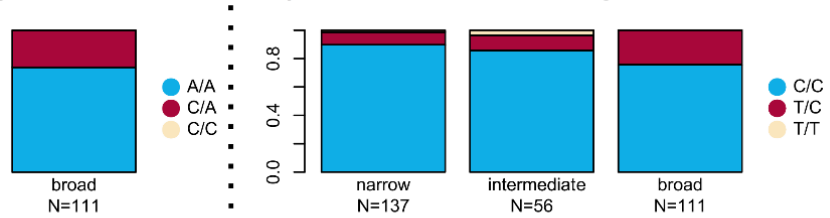

p) MA_39589g0010.566 -pooled data

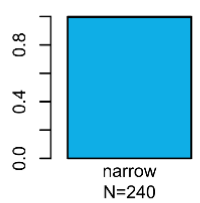

$\mathrm{N}=240$
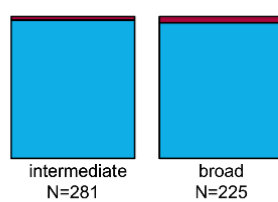

q)

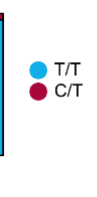

MA_39589g0010.566 -Harz

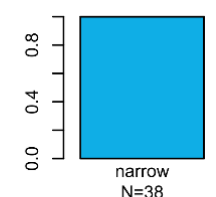

narrow
$\mathrm{N}=38$

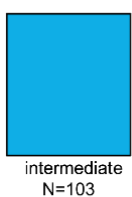

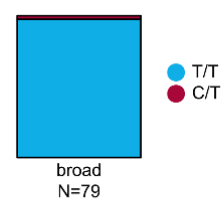

r) MA_39589g0010.566 -Thuringia
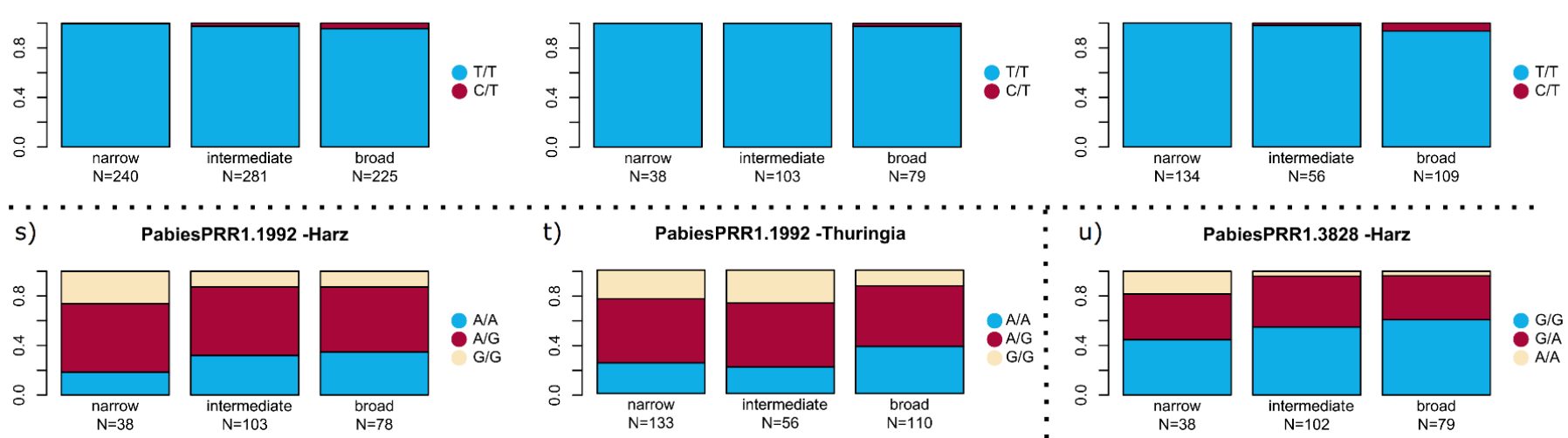

t)

PabiesPRR1.1992 -Thuringia
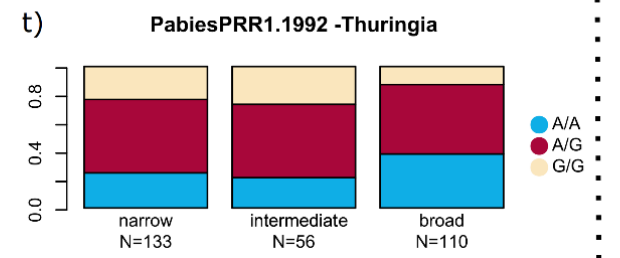

u)

PabiesPRR1.3828 -Harz

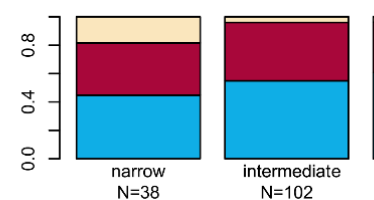

Figure S8 Frequency distribution of SNP genotypes in phenotypic groups of selected loci and datasets (a-u). Presented are locus/dataset combinations that were highly significant according to at least one detection method or showed nominal significance for the same dataset for several methods. Plots representing the same SNP in different datasets are separated from the others by dotted lines. SNP and dataset names are indicated above each plot. 
Table S1 Climatological data for the sample stands.

\begin{tabular}{|c|c|c|c|c|c|c|c|}
\hline Stand & $\begin{array}{l}\text { Age of } \\
\text { Upper } \\
\text { Story } \\
\text { Trees, } \\
\text { years }\end{array}$ & $\begin{array}{c}\text { Mean } \\
\text { Multi } \\
\text { Annual } \\
\text { Air } \\
\text { Tempera } \\
\text { ture } \\
1981- \\
2010,{ }^{\circ} \mathrm{C}\end{array}$ & $\begin{array}{c}\text { Mean } \\
\text { Vegetat } \\
\text { ion } \\
\text { Period } \\
\text { in } \\
\text { 1992- } \\
2015, \\
\text { days } \\
\end{array}$ & $\begin{array}{c}\text { Mean } \\
\text { Snow } \\
\text { Cover } \\
\text { Days in } \\
1981- \\
2010, \\
\text { days }\end{array}$ & $\begin{array}{l}\text { Annual } \\
\text { Mean } \\
\text { Precipita } \\
\text { tion in } \\
\text { 1981- } \\
2010, \\
\text { mm }\end{array}$ & $\begin{array}{c}\text { Mean } \\
\text { Wind in } 20 \\
\mathrm{~m} \text { a.g.I. } \\
\mathrm{m} / \mathrm{s} \text { in } \\
1981- \\
2000\end{array}$ & $\begin{array}{c}\text { Elevation } \\
\text { Range Of } \\
\text { Sampled } \\
\text { Individuals, m } \\
\text { a.s.l. }\end{array}$ \\
\hline LE_H & 180 & 4.7 & 181.0 & 141.5 & 1668.5 & 56 & 889-915 \\
\hline HE_H & $300 *$ & 3.9 & 177.0 & 158.0 & 1793.0 & 79 & $1036-1065$ \\
\hline LE_S & 162 & 5.2 & 184.0 & 127.0 & 1210.0 & 55.5 & $972-1009$ \\
\hline HE_S & 142 & 4.9 & 182.0 & 136.0 & 1255.0 & 58 & 988-1014 \\
\hline LE_T & 90 & 5.7 & 190.0 & 122.0 & 1331.0 & 57 & 899-912 \\
\hline $\mathrm{HE}_{-} \mathrm{T}$ & 151 & 6.3 & 195.5 & 100.5 & 1211.0 & 39 & $761-776$ \\
\hline SBF_T & $280 *$ & 5.8 & 191.0 & 116.0 & 1331.0 & 50 & $818-840$ \\
\hline Mean & & 5.2 & 185.8 & 128.7 & 1399.9 & 56.4 & 921 \\
\hline
\end{tabular}

Mean air temperature, mean length of the vegetation period, mean number of days with a snow cover $>1 \mathrm{~cm}$ in the morning, mean annual precipitation, mean wind speed at $20 \mathrm{~m}$ above ground level, and the elevation range in the sampled stands. LE: Low elevation type; HE: High elevation type; SBF: "Schlossbergfichte"; S: Ore Mountains (Saxony); T: Thuringia; H: Harz Mountains. Values for climatological parameters were taken from extrapolated $1 \times 1 \mathrm{~km}$ grid maps of the long-term average measurements (Deutscher Wetterdienst DWD Climate Data Center (CDC)). For individuals falling in different grids, the mean of these grid values is given and used for calculation of the total mean. The mean vegetation period is calculated from the grid values of the mean end-date minus the mean starting-date of the vegetation period (both are presented in days from New Year). Elevation data were taken from the GPS data. Stand age according to information given by the forestry officials. * The age of the "Schlossbergfichte" population is based on the oldest trees (Jetschke 2019, Wilhelm 1990), and the age of the HE_Harz population is based on the oldest trees of equivalent stands at Mt. Brocken (Meyer et al. 2017). (Table according to Caré et al. 2018) 
Table S2 Summary of results for the different methods used to detect association between SNP loci and crown phenotype. Significant outcomes based on the generalized linear model (GLM), $F_{S T}$-outliers, and significant allelic differentiation $\left(\delta_{S D}\right)$ between individuals grouped by their phenotypes for each SNP are marked and detected SNPS highlighted in grey.

\begin{tabular}{|c|c|c|c|c|c|c|c|c|c|c|c|c|c|c|}
\hline \multirow[t]{2}{*}{ Gene $^{\mathrm{a}}$ (encoded putative } & \multirow[t]{2}{*}{ SNP } & \multicolumn{2}{|c|}{$\begin{array}{c}F_{\mathrm{ST}^{-}} \\
\text {outlie } \\
\mathrm{rs}^{\mathrm{b}}\end{array}$} & \multicolumn{3}{|c|}{ GLM $^{c}$} & \multicolumn{4}{|c|}{ GLM $^{d}$} & \multicolumn{4}{|c|}{$\delta_{S D}^{\mathrm{e}}$} \\
\hline & & $T$ & $\mathrm{H}$ & $P$ & $\mathrm{~T}$ & $\mathrm{H}$ & $P$ & $T$ & $\mathrm{H}$ & $\mathrm{s}$ & $P$ & $T$ & $\mathrm{H}$ & $\mathrm{s}$ \\
\hline \multirow{3}{*}{$\begin{array}{c}\text { MA_2193g0020 (AP2-like factor, } \\
\text { APL2L3) }\end{array}$} & AP2L3-2319 & 0 & & & & & & & & & & - & & \\
\hline & AP2L3-2842 & $\diamond$ & & & & & & & & & & - & & \\
\hline & AP2L3-2907 & & & & & & & & 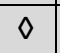 & & & $\bullet$ & & \\
\hline $\begin{array}{c}\text { MA_470416g0010 (response regulator } \\
\text { ARR-A family) }\end{array}$ & ARRL-214 & & & & & & & & & & & & & \\
\hline \multirow{2}{*}{$\begin{array}{c}\text { MA_137887 (D6 protein kinase like 2, } \\
\text { BIF2L2) }\end{array}$} & BIF2L2-423 & & & $\diamond$ & & & 0 & 0 & $\Delta$ & & & & & \\
\hline & BIF2L2-747 & & & & & 0 & & & $\diamond$ & & 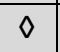 & & 0 & \\
\hline $\begin{array}{l}\text { MA_86404g0010 (large subunit } \\
\text { ribosomal protein L5) }\end{array}$ & FCL3066Contig1-663 & & & & & & & & & & & & & \\
\hline \multirow{2}{*}{ MA_19575g0010 (gigantea protein, GI) } & GI6-1089 & & & $\bullet$ & $\bullet$ & & $\bullet$ & $\bullet$ & & & & $\diamond$ & & \\
\hline & GI6-1207 & & & $\bullet$ & $\bullet$ & & $\bullet$ & $\bullet$ & & & & $\diamond$ & & \\
\hline \multirow{4}{*}{$\begin{array}{l}\text { MA_108198g0010 (floral meristem } \\
\text { identity control protein LEAFY, LFY) }\end{array}$} & LFY-1307 & & & & & & & & & & & & & \\
\hline & LFY-2961 & & & & & & & & & & & & & \\
\hline & LFY-357 & & & & & & & 0 & & & & & & \\
\hline & LFY-637 & & & & & & $\Delta$ & & & & & $\Delta$ & & \\
\hline \multirow{2}{*}{$\begin{array}{c}\text { MA_101803g0010 (similar to CHASE } \\
\text { domain containing histidine kinase } \\
\text { protein) }\end{array}$} & $\begin{array}{l}\text { MA_101803g0010- } \\
16597\end{array}$ & & & & & & & & & & & & & \\
\hline & MA_101803g0010-2450 & & & & & & & & & & & & & \\
\hline MA_10267291g0010 (?) & $\begin{array}{l}\text { MA_10267291g0010- } \\
503\end{array}$ & & & & & & & & & & & & & \\
\hline MA_18142g0010 (aminotransferase) & MA_18142g0010-1959 & & & & & & & & & & & & & \\
\hline $\begin{array}{l}\text { MA_20378g0010 (myosin family } \\
\text { protein with Dil domain) }\end{array}$ & MA_20378g0010-7419 & & & & & & & & & & & & & \\
\hline $\begin{array}{l}\text { MA_39589g0010 (mTERF/ } \\
\text { mitochondrial transcription } \\
\text { termination factor-related) }\end{array}$ & MA_39589g0010-566 & & $\diamond$ & $\bullet$ & $\bullet$ & & 0 & $\bullet$ & & & $\diamond$ & 0 & & \\
\hline MA_57678g0010 (cytochrome P450) & MA_57678g0010-2862 & & & & & & & $\Delta$ & & & & & & \\
\hline $\begin{array}{c}\text { MA_605776g0010 (heat shock protein } \\
\text { 21) }\end{array}$ & MA_605776g0010-849 & & & & & & & & & & & & & \\
\hline $\begin{array}{c}\text { MA_73095g0010 (response regulator } \\
\text { 3) }\end{array}$ & MA_73095g0010-1374 & & & & & & & $\Delta$ & & & & & & \\
\hline MA_184576g0010 (?) & $\begin{array}{l}\text { NODE-60-length-1132- } \\
\text { cov-157.795929-418 }\end{array}$ & & & & & 0 & & & $\diamond$ & & & & & $\Delta$ \\
\hline
\end{tabular}




\begin{tabular}{|c|c|c|c|c|c|c|c|c|c|c|c|c|c|c|}
\hline \multirow[t]{2}{*}{ Gene $^{\mathrm{a}}$ (encoded putative } & \multirow[t]{2}{*}{ SNP } & \multicolumn{2}{|c|}{$\begin{array}{c}F_{\mathrm{ST}^{-}} \\
\text {outlie } \\
\mathrm{rs}^{\mathrm{b}}\end{array}$} & \multicolumn{3}{|c|}{ GLM $^{c}$} & \multicolumn{4}{|c|}{ GLM $^{d}$} & \multicolumn{4}{|c|}{$\delta_{S D}^{\mathrm{e}}$} \\
\hline & & $\mathrm{T}$ & $\mathrm{H}$ & $\mathrm{P}$ & $T$ & $\mathrm{H}$ & $\mathrm{P}$ & $\mathrm{T}$ & $\mathrm{H}$ & $\mathrm{s}$ & $P$ & $T$ & $\mathrm{H}$ & $\mathrm{s}$ \\
\hline $\begin{array}{l}\text { MA_18664g0010 (phytochrome- } \\
\text { associated protein 1) }\end{array}$ & P02773-3 & & & & & & & & & & & & & \\
\hline $\begin{array}{l}\text { MA_104065g0020 (Barwin-like } \\
\text { endoglucanases superfamily protein) }\end{array}$ & P06971-3 & & & & & & $\diamond$ & & & $\diamond$ & & & & \\
\hline \multirow{8}{*}{$\begin{array}{l}\text { MA_71728g0010 (PRR1, CCT motif - } \\
\text { containing response regulator protein) }\end{array}$} & PabiesPRR1-1992 & & & & & & & 0 & & 0 & & 0 & 0 & $\diamond$ \\
\hline & PabiesPRR1-2068 & & & & & & & & & & 0 & & & \\
\hline & PabiesPRR1-2381 & & & & & & & & & & & & & \\
\hline & PabiesPRR1-240 & & & & & & & & & & & $\diamond$ & & \\
\hline & PabiesPRR1-2741 & & & & & & & & & & & & & \\
\hline & PabiesPRR1-3828 & & & & & 0 & & & 0 & & & & 0 & \\
\hline & PabiesPRR1-4071 & & & & & & & & & & & & & \\
\hline & PabiesPRR1-4365 & & & & & & 0 & & & 0 & & & & \\
\hline \multirow{2}{*}{$\begin{array}{l}\text { MA_124244g0020 (PRR7, pseudo- } \\
\text { response regulator 7) }\end{array}$} & PabiesPRR7-F1-2518 & & & & & & & & & & & & & \\
\hline & PabiesPRR7-F2-534 & & & & & & & & & & & & & \\
\hline \multirow{3}{*}{ MA_73153g0010 (phytochrome B) } & PaPHYN-R0319 & & & & & & & & & & & & & \\
\hline & PaPHYN-RI204 & & & & & & & & & & & & & \\
\hline & PaPHYN-RI420 & & & & & & & & & & & & & \\
\hline MA_6809g0020 (phytochrome A) & PaPHYO-RII283 & & & & & & & & 0 & & & & & \\
\hline \multirow{2}{*}{ MA_6809g0030 (phytochrome A) } & PaPHYO-RIII510 & & & & & & & & & & & & & \\
\hline & PaPHYO-RIV39 & & & & & & & & & & & & & \\
\hline \multirow{2}{*}{ MA_10435530g0010 (phytochrome B) } & PaPHYP-RI308 & & & & & & & & 0 & & & & & \\
\hline & PaPHYP-RI96 & & & & & & & & & & & & & \\
\hline MA_10437131g0030 (?) & PRR3BC-903 & & & & & & & & & & & & 0 & \\
\hline
\end{tabular}

abased on http://congenie.org; ${ }^{b}$ computed using Lositan software (Antao et al. 2008); GLM included neutral population structure with $K=2$ clusters as a confounding factor and was computed using the Tassel ${ }^{c}$ (Bradbury et al. 2007) and SNPassoc ${ }^{d}$ (González et

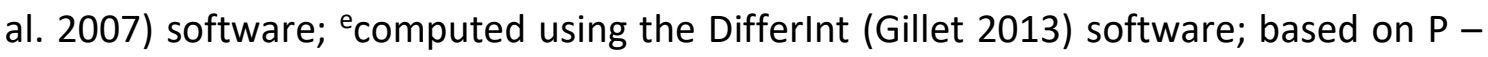
pooled, H - Harz, T - Thuringian, and S - Saxonian samples; $\diamond$ and $\bullet-$ significant associations or differentiations for nominal $p$-values $\leq 0.05$ or the FDR-adjusted $q$-value $\leq 0.05$, respectively. 
6.3. Chapter II-Supplementary Materials 3: Additional results and discussion on nominal significant SNPs

\section{Crown morphology in Norway spruce (Picea abies [Karst.] L.) as} adaptation to mountainous environments is associated with single nucleotide polymorphisms (SNPs) in genes regulating seasonal growth rhythm

published in: Tree Genetics and Genomes

Oliver Caré, Oliver Gailing, Markus Müller, Konstantin V. Krutovsky and Ludger Leinemann

corresponding author: Oliver Gailing, Department of Forest Genetics and Forest Tree Breeding, Büsgen-Institute, Faculty of Forest Sciences and Forest Ecology, GeorgAugust University of Göttingen, 37077 Göttingen, Germany, e-mail: ogailin@gwdg.de; phone: +49-551-3933536

\section{PRR1}

The sequence MA_71728g0010 codes for a pseudo response regulator 1 (PRR1) also known as TIMING OF CAB EXPRESSION 1 . Similar to the $G /$ gene in Picea abies, it is a core circadian clock gene. Within the sequence, two SNPs showed nominal significance for two and three methods, respectively. Interestingly, PaPRR1-1992 represents a nonsynonymous SNP with a replacement of the hydrophobic, nonpolar glycine (G) by the polar, hydrophile serine $(S)$ in the protein sequence at position 56. crown type groups were significantly differentiated at the SNP PaPRR1-1992 in all regions, as measured by $\delta_{S D}$ (Table 1). In the Harz Mountain and Thuringia, the broad-crowned group had a lower proportion ( $13 \%$ ) of the G/G homozygotes than the narrow-crowned group ( 24\%) (Fig. S8 s \& t), whereas in Saxony the opposite pattern was observed. Both the GLM and the differentiation ( $\delta_{S D}$ ) analyses gave significant $p$-values for PabiesPRR13828 in the Harz dataset. Similar to PabiesPRR1-1992, PabiesPRR1-3828 in the Harz samples had a higher proportion of the most common homozygote in the broad crown group (Fig. S8 u).

The genotype frequency for both nominal significant SNPs PabiesPRR1-1992 and 3828 showed an increase of the minor homozygote in narrow-crowned trees. Such pattern was also reported for SNPs in PRR1 in Pinus sylvestris from gradient with proposed adaptive role in climatic adaptation (Kujala and Savolainen 2012). In Poplar, $P R R 1$ is involved in cold tolerance, bud set, and bud burst and is crucial to set the critical day length for growth cessation (Ibáñez et al. 2010). It also has a role in abscisic acid sensitivity, a plant hormone involved amongst others in seed dormancy and potentially bud dormancy (Cooke et al. 2012). Gene expression levels reach their peak at dusk 
(Gyllenstrand et al. 2014) and as with GI, the PRR1 expression patterns suggest a synchronising role of the circadian clock genes to the local environment (Alakärppä et al. 2018).

\section{D6PKL2}

The best Blast hit of MA_137887 was an Arabidopsis gene coding for a D6PKL protein. In Arabidopsis, it is involved in the plant reaction to cold stress (Sun et al. 2009). Two SNPS, BIF2L2-423 and BIF2L2-747, showed nominal significance across methods. Genotype distributions at BIF2L2-423 among groups differed significantly with a higher frequency of the homozygote $G / G$ in the narrow-crowned individuals - $46.1 \%$ in the pooled, $55.3 \%$ in the Harz and $41.6 \%$ in the Thuringian datasets (Fig. S8 d-f). Comparing the BIF2L2-747 genotype distributions between phenotypic groups in the Harz Mountain, a higher frequency of the $C / C$ homozygote or $C / T$ heterozygote was observed in the broad crowned group (Fig. S8 h).

For both nominal significant SNPs and across sites a tendency to a higher proportion of the most common homozygotes and alleles (G/G for BIF2L_423 and T/T for BIF2L2$747)$ in the group of narrow-crowned trees was noticed. The putative involvement of D6PK in polar auxin transport in Arabidopsis and its role in plant development and growth (Willige et al. 2013; Miao et al. 2018; Zhou and Luo 2018) makes it a candidate gene also for plant structure.

\section{UF}

Both GLM analyses revealed significant results for the NODE-60-length-1132cov157.795929-418 SNP in the Harz dataset (Table 1). The homozygote $A / A$ was slightly less abundant in the narrow-crowned individuals than in the other groups. In the narrow-crowned trees both heterozygote and homozygote $A / A$ had equal proportions. The minor homozygote $T / T$ was only observed in the intermediate and broad-crowned trees, with higher frequency in the latter (Fig. S8 j).

The function of this gene is unknown, but it has previously been found that it has a highly significant association with the content of trans-resveratrol and trans-piceatannol in needles of Picea abies (Ganthaler et al. 2017b). Trans-resveratrol is a phytoalexin synthesised in several plant families in response to phytopathogenic microorganisms (Jeandet et al. 2010; Ahuja et al. 2012; Ribera and Zuñiga 2012). The observed genotype distributions were similar between Harz and Thuringia, where broad and intermediate crown trees more often had the variant for higher trans-resveratrol and transpiceatannol content. 
7. Chapter III - Mating system in a native Norway spruce (Picea abies [L.] KARST.) stand - Effective population size and relatedness show the tendency of an association with the germination percentage of single tree progenies.

Oliver Caré, Oliver Gailing, Markus Müller, Konstantin V. Krutovsky, Ludger Leinemann

$\begin{array}{ll}\text { Journal: } & \text { Diversity } \\ \text { Volume: } & 12 \\ \text { Issue: } & 7 \\ \text { Year: } & 2020 \\ \text { Publisher: } & \text { MDPI } \\ \text { Copyright: } & \text { Cby the authors under the terms and conditions of the Creative } \\ & \text { Commons Attribution (CC BY) license } \\ & \text { (https://creativecommons.org/licenses/by/4.0/) } \\ \text { Published: } & 3 \text { July 2020 } \\ \text { DOI: } & \text { 10.3390/d12070266 } \\ \text { URL: } & \text { https://www.mdpi.com/1424-2818/12/7/266 }\end{array}$

Autor contributions:

Conceptualization: O.C., O.G., M.M., K.K. and L.L.; Methodology: O.C., O.G., M.M., K.K. and L.L.; Software: O.C.; Validation: O.C., O.G., M.M., K.K. and L.L.; Formal analysis: O.C.; Investigation: O.C.; Data curation, O.C.; Writing-original draft preparation, O.C.; Writing-review and editing, O.C., O.G., M.M., K.K. and L.L.; Visualization, O.C.; Supervision, O.G. and L.L.; Project administration, O.G. and L.L.; Funding acquisition, O.G., M.M, and L.L. (listed based on position in author list, CRediT taxonomy) 


\title{
Mating System in a Native Norway Spruce (Picea abies [L.] KARST.) Stand-Relatedness and Effective Pollen Population Size Show an Association with the Germination Percentage of Single Tree Progenies
}

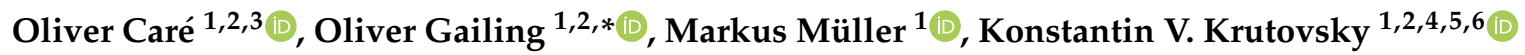 \\ and Ludger Leinemann ${ }^{1,3}$ \\ 1 Department of Forest Genetics and Forest Tree Breeding, Georg-August University of Göttingen, \\ 37077 Göttingen, Germany; oliver.care@forst.uni-goettingen.de (O.C.); \\ markus.mueller@forst.uni-goettingen.de (M.M.); kkrutov@gwdg.de (K.V.K.); lleinem@gwdg.de (L.L.) \\ 2 Center for Integrated Breeding Research (CiBreed), Georg-August University of Göttingen, \\ 37075 Göttingen, Germany \\ 3 ISOGEN GmbH \& Co.KG, 37077 Göttingen, Germany \\ 4 Department of Ecosystem Science and Management, Texas A\&M University, College Station, TX 77840, USA \\ 5 Laboratory of population genetics, Vavilov Institute of General Genetics, Russian Academy of Sciences, \\ 119991 Moscow, Russia \\ 6 Genome Research and Education Centre, Siberian Federal University, 660036 Krasnoyarsk, Russia \\ * Correspondence: ogailin@gwdg.de
}

Received: 5 June 2020; Accepted: 1 July 2020; Published: 3 July 2020

\begin{abstract}
Norway spruce differs little in neutral genetic markers among populations and provenances often reported, but in terms of putative adaptive traits and their candidate genes, some clear differences have been observed. This has previously been shown for crown morphotypes. Stands with mostly narrow crown shapes are adapted to high elevation conditions, but these stands are scattered, and the forest area is often occupied by planted stands with predominantly broad crowned morphotypes. This raises questions on whether this differentiation can remain despite gene flow, and on the level of gene flow between natural and planted stands growing in close neighbourhood. The locally adapted stands are a valuable seed source, the progeny of which is expected to have high genetic quality and germination ability. The presented case study is useful for spruce plantation by demonstrating evaluation of these expectations. Immigrant pollen and seeds from planted trees could be maladaptive and may alter the genetic composition of the progeny. This motivated us to study single tree progenies in a locally adapted stand with narrow crowned trees in a partial mast year at nuclear genomic simple sequence repeat (SSR) markers. Spruce is a typical open-pollinated conifer tree species with very low selfing rates, which were also observed in our study $(s=0.3-2.1 \%)$ and could be explained by efficient cross-pollination and postzygotic early embryo abortion, common in conifers. The estimated high amount of immigrant pollen found in the pooled seed lot (70.2-91.5\%) is likely to influence the genetic composition of the seedlings. Notably, for individual mother trees located in the centre of the stand, up to $50 \%$ of the pollen was characterised as local. Seeds from these trees are therefore considered to retain most of the adaptive variance of the stand. Germination percentage varied greatly between half-sib families (3.6-61.9\%) and was negatively correlated with relatedness and positively with effective pollen population size of the respective families. As pollen mostly originated from outside the stand and no family structures in the stand itself were found, germination differences can likely be explained by diversity differences in the individual pollen cloud.
\end{abstract}

Keywords: parentage assignment; paternity analysis; pollen dispersal; gene flow; mating system; inbreeding effect; outbreeding 


\section{Introduction}

Historically, forest areas were heavily exploited and reforested in Germany, and older stands were often planted with unknown and potentially unsuitable plant material [1]. Typically, local stands of Norway spruce at higher elevations are characterised by trees with a narrow crown and plate-like branching adapted to sustain heavy snowfall [2,3]. In the past, due to limited availability of planting material from desired provenances or lack of attention in selection of material, spruce stands were often established using seeds or seedlings representing lowland morphotypes. Recently, Caré et al. [4] showed adaptive differentiation at candidate genes between high and low elevation morphotypes.

Adapted autochthonous stands are valuable for in situ conservation of genetic resources and as the main seed sources for artificial regeneration [1]. Therefore, there are two important aspects related to the genetic composition of the offspring: (1) the natural regeneration of the stand itself, and (2) the usage of the seeds for production and subsequent plantation of seedlings. As a wind-pollinated monoecious species, Norway spruce is characterised by high outcrossing rates and long-distance pollen dispersal [5-8]. The high outcrossing rates can, not only be explained by effective wind-mediated pollen flow, but also by postzygotic abortion of inbred embryos, decreasing the selfing rates estimated in viable seeds. Early studies in the genus Picea spp. detected no self-incompatibility, but did detect unviability of selfed embryos caused by inbreeding depression $[9,10]$. Inbreeding depression in Picea abies [L.] KARST. also lowers germination percentage and speed and negatively affects growth traits and the viability of young trees [11]. At later ontogenetic stages it strongly reduces tree volume and height and increases mortality compared to individuals from open pollinated seeds [12].

Pollen-mediated gene flow in conifers occurs at the local population scale as a distance dependent process with a typically exponential decrease with increasing distance. However, long distance gene flow occurs by pollen lifted in upper air-layers and transported over several or even hundreds of kilometres $[7,8,13,14]$. This leads to the overall low differentiation of Norway spruce populations at neutral markers observed throughout the distribution range of the species [15]. Long-distance gene flow and immigrant pollen could have various impacts on the genetic composition of a local population. Gene flow between populations, on the one hand, leads to a distribution of genetic information across the population range, possibly counteracting effects of genetic drift or inbreeding and distributing potentially important gene variants for adaptation, that even might assist the adaptive processes to climatic changes. On the other hand, it may alter local adaptation by changing allele frequencies and gene complexes [16].

We studied seed samples from single tree progenies (half-sib families) ripened after a partial mast year. The samples were collected in a putatively adapted and autochthonous spruce stand of mainly narrow to intermediate crowned individuals that grow at higher elevations of the Thuringia Forest in Germany and that have previously showed signs of genetic adaptation to the mountainous environment [4]. The area is also characterised by a high proportion of planted stands typically consisting of broad crowned individuals. The sampled stand is used as a seed source to produce reproductive material of mountainous provenance. Thus, potentially extended gene flow from the surrounding stands might introduce undesired characteristics to the progeny, and our results could be helpful in the evaluation of the stand as seed source.

Genetic analysis combined with observation of germination was conducted to address the following objectives: (1) assigning progeny to potential pollen donors to examine the mating system, (2) quantifying the amount of pollen originated from within the autochthonous stand or migrated from the surrounding stands to assess possible impacts on adaptive genetic variation, and (3) observing the germination rate of seed samples from each half-sib family and estimating genetic differences between them, considering also a possible link between genetics and fitness. 


\section{Materials and Methods}

\subsection{Plant Material}

Cones from 21 trees were collected in March 2017 in a pure Norway spruce stand located in the Thuringian forest at $\sim 770 \mathrm{~m}$ a.s.l. (above sea level), where the forest area is dominated by pure spruce stands. This sample represents a partial mast year, with seed ripening in 2016. The mother-trees were selected in three groups representing the northern and south-eastern edges, as well as the central part of the stand, respectively. Cones and seeds were collected, kept and studied separately for each mother tree representing half-sib family samples from open pollination. Preceding the cone collection, 200 adult trees in this stand were initially genotyped at nuclear genomic microsatellite or genomic simple sequence repeat (SSR) markers (gSSRs) and expressed sequence tag SSR markers (EST-SSRs) [17] including the 21 mother trees, the seeds of which were used here to study germination and infer potential pollen donors (Figure 1a). The stand is considered autochthonous and used for harvesting seeds for forest reproductive material. Stand location and topographic features of the region are displayed in Figure 1b,c. Trees within the stand are mainly characterised by a narrow to intermediate crown shape with plate-brush or plate-like secondary branching pattern [17]. Narrow crowned trees with plate-like branching are typical high elevation morphotypes.

a)
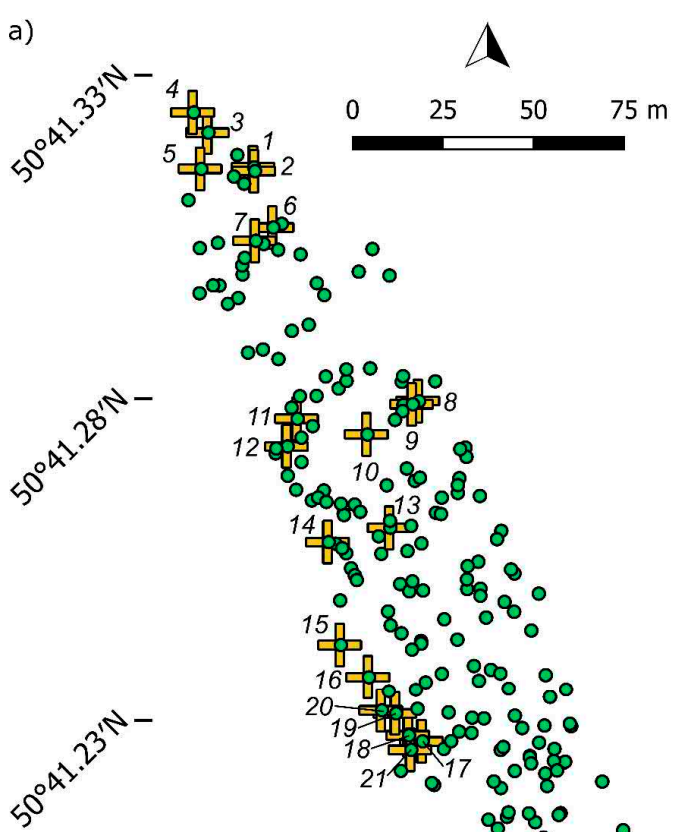

I

$10^{\circ} 49.69^{\prime} \mathrm{E}$

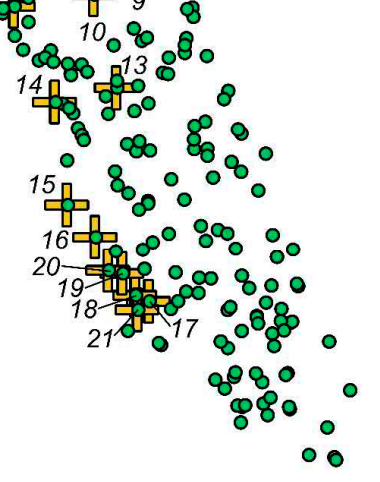

$10^{\circ} 49.75^{\prime} \mathrm{E}$ b)

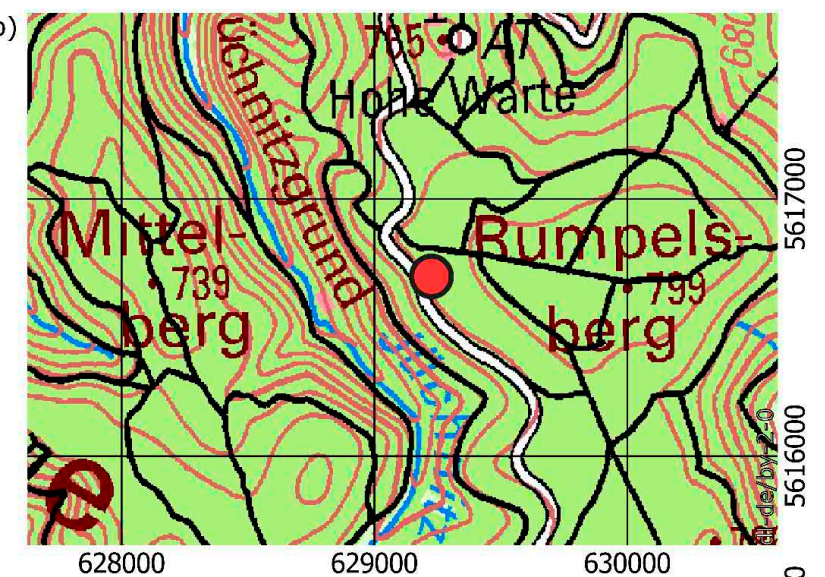

c)

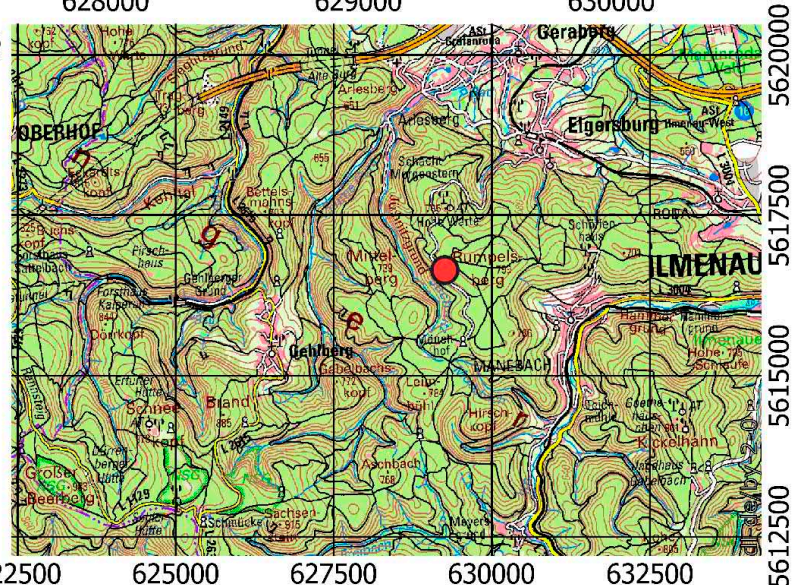

Figure 1. (a) Map of the 200 genotyped adult trees (green dots) including 21 seed-sampled mother trees labelled by numbers corresponding to the half-sib family numbers in Table 1 and depicted by yellow cross symbols over green dots. Coordinates are given in WGS 84 (EPSG: 4326). Topographic map at 1:25,000 (b) and 1:1000,000 (c) scales with the stand location indicated by the red dot. Coordinates are given in ETRS89/UTM zone 32N (EPSG: 25832). Map source: www.geoportal-th.de [18], URI: L5330_col and C5530_col, respectively, and available under the "dl-de/by-2-0" licence at http://www.govdata.de/ dl-de/by-2-0. Figure generated with QGIS 3.8. 


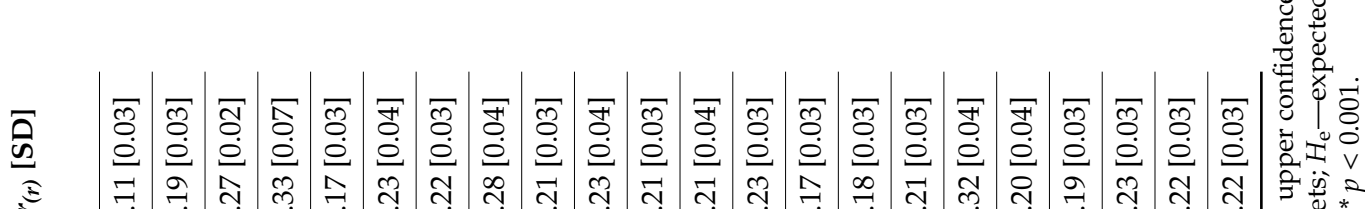

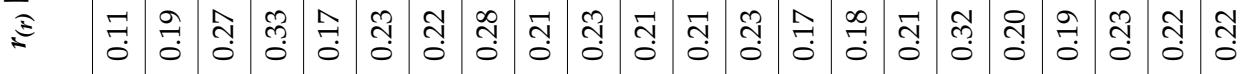

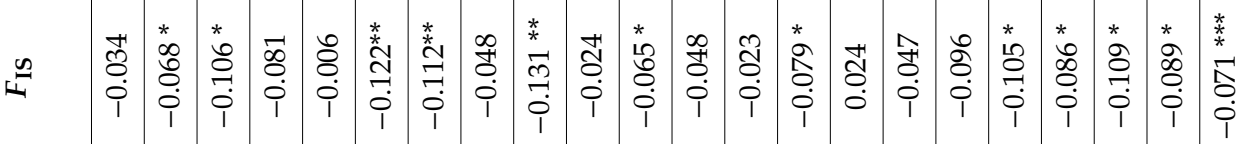

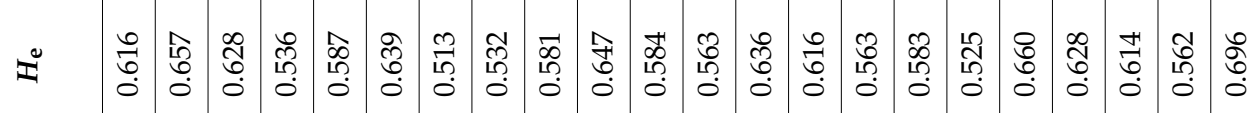

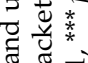

-

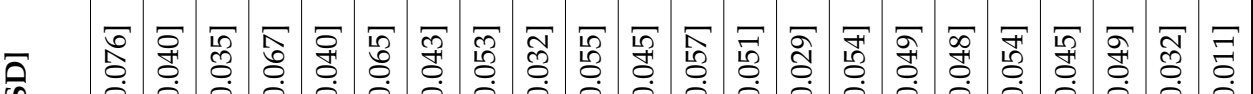

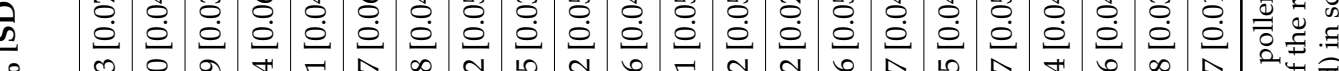

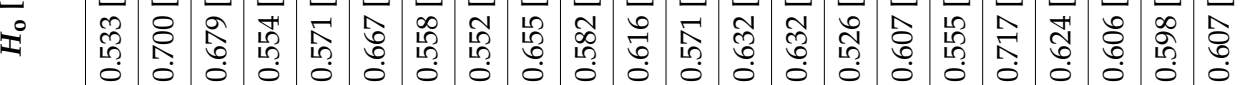

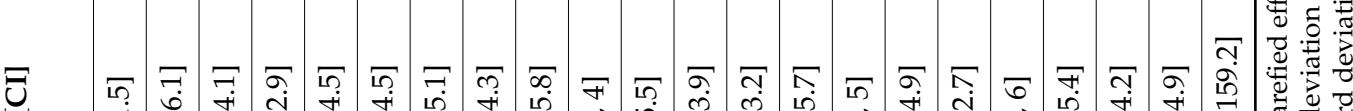

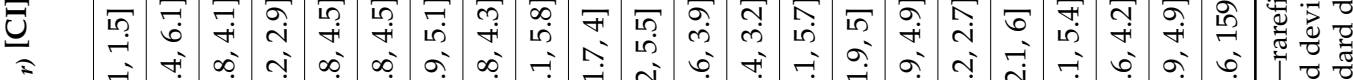
Z

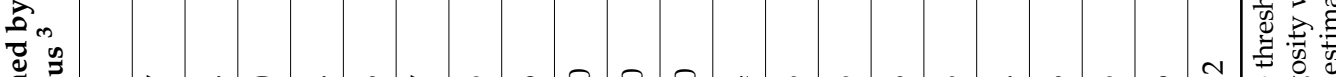

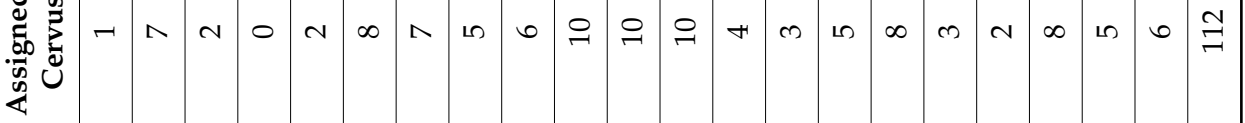

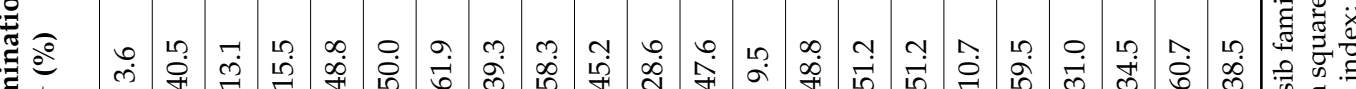

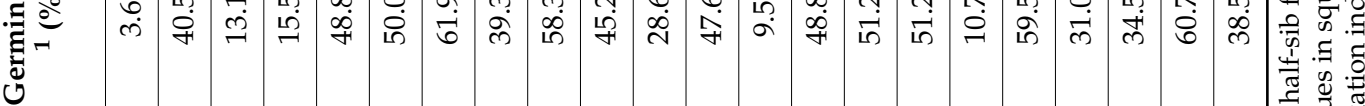




\subsection{Observation of Germination}

The collected cones were dried to extract the seeds, which were manually cleaned and then stored at $8{ }^{\circ} \mathrm{C}$. Germination was observed for 84 seeds per tree. Seeds were put on top of moist paper tissue in Petri dishes that were subdivided in segments for single-seed-identification. During the 10-day observation period, the seeds were kept moist under ambient conditions in the laboratory. Germination was assessed daily, where each seed was scored whether (1) its seed coat was dehisced, (2) the seed coat was dehisced and the root tip was visible, (3) the root had started to elongate or (4) the seed showed no signs of germination. For each tree 20 seeds were randomly selected for genotyping. They were used for DNA-extraction either when the root emerged or after 10 days without germination. If a selected seed was empty and could not be used for extraction, another random seed was used. For five trees less than 20 seeds could be used for DNA extraction due to the high proportion of empty seeds. Nevertheless, all seeds prepared for DNA extraction could be genotyped successfully.

\subsection{DNA Extraction and Genotyping}

For DNA extraction, seeds were dissected to isolate embryo and megagametophyte and, then, to genotype them separately. This enables us to determine separately individual paternal and maternal contributions to the genotype of the embryo. DNA extraction was carried out according to the manufacturer's protocol using the DNeasy 96 Plant Kit (Qiagen, Hilden, Germany) with prior freezing of embryo or megagametophyte tissues in liquid nitrogen and grounding them in a MM300 ball mill (Retsch, Haan, Germany) for $2 \mathrm{~min}$ at $30 \mathrm{~Hz}$.

Genotyping of 200 adult trees (including the 21 trees from which seed samples were taken and the potential pollen donors) at gSSRs and EST-SSRs had been performed by Caré et al. [17]. Here, embryos and corresponding megagametophytes were genotyped accordingly at the same seven gSSRs $[19,20]$ and three out of four EST-SSRs [21,22] (Table S1). The EST-SSR PaGB8 was excluded to increase parent-offspring assignment accuracy, because this marker often had a stuttering pattern, which may cause misgenotyping that negatively affects assignment probability. PCR reactions were performed the same way as for the adult trees in $14 \mu \mathrm{L}$ total volume containing $1 \mu \mathrm{L}$ of 1:10 diluted DNA mixed with $1 \mathrm{X}$ reaction buffer B (Solis BioDyne, Tartu, Estonia), $2.68 \mathrm{mM} \mathrm{MgCl}_{2}, 178.57 \mu \mathrm{M}$ for each dNTP, and one unit of HOT FIREPol ${ }^{\circledR}$ (Solis BioDyne, Tartu, Estonia) Taq polymerase. Multiplex combinations of primer pairs and their concentrations are provided in Table S2. Reactions were run in a Biometra TProfessional Basic thermocycler (Analytic Jena AG, Jena, Germany) using a touch-down PCR protocol (Table S3) followed by fragment separation on an $\mathrm{ABI}^{\mathrm{TM}}$ 3130xl Genetic Analyzer (Applied Biosystems, Foster City, CA, USA) with the size standard GeneScan ${ }^{\mathrm{TM}} 500$ ROX ${ }^{\mathrm{TM}}$ (Applied Biosystems, Foster City, CA, USA) and peak calling using GeneMapper ${ }^{\mathrm{TM}}$ v4.1 software (Applied Biosystems, Foster City, CA, USA).

\subsection{Statistical Analysis}

Quality control genotyping and allele calling were validated by inspecting whether at least one allele found in the embryo matched the allele in the corresponding megagametophyte and that this allele matched at least one allele in the respective mother tree. The haplotype of male gametes in the pollen contributing to the formation of the seed was inferred by subtracting the megagametophyte haplotype from the corresponding embryo genotype. In rare cases $(<1 \%)$, when no data for the megagametophyte were available, and the embryo had both alleles in common with the mother tree the male contribution could not be determined. Then, both alleles were considered as potential male contribution in the assignment analysis. Not excluding these cases from the analysis as undefined missing data help to better resolve the number of potential pollen-donors. One tree was discarded from the analysis of potential pollen donors, as it was successfully genotyped at only five loci.

Individual observed heterozygosity $(H)$ of the embryo was calculated as a proportion of heterozygous loci among all loci genotyped. Fixation index $\left(F_{I S}\right)$, which was used as a proxy 
for inbreeding coefficient, its corresponding $p$-value after 50,000 permutations, mean observed $\left(H_{0}\right)$ and expected $\left(H_{e}\right)$ heterozygosity over all loci were calculated for each half-sib family and for the entire pooled sample using Arlequin 3.5.2.2 [23]. To account for uncertainties from unequal sample size the standard deviation of the mean $H_{o}$ from 10,000 rarefaction resampling to $n=10$ was calculated. The $H_{e}$ within the stand and the seed lot was also calculated and compared to the half-sib families $H_{o}$ to estimate potential loss of heterozygosity across generations. Visualisation of dissimilarities among embryos and also adult trees that represent potential pollen donors in the stand was performed by principal coordinate analysis (PCoA) using the R-package ape v.5.2 [24] and pairwise Hamming distances [25] calculated using the R-package poppr v.2.8.1 [26,27], which can be regarded as genetic distance based on allelic differences between individual embryos or adult trees. Outbreeding rate for each half-sib family was calculated as the number of seeds without an assigned pollen donor in the stand divided by the total number of genotyped seeds. Germination percentage was calculated as the percentage of germinated seeds from the initial 84 seeds. To assess association between genotypes and germination percentage and time, linear regression was applied considering the germination time or percentage as a response variable and genetic indices as fixed effect.

Effective population size $\left(N_{e}\right)$ was estimated using the R-package $N B$ v.0.9 [28] based on a maximum likelihood approach [29] from the change in allele frequencies between the parent and offspring generation. Since each offspring sample represents a half-sib family, differences between the maternal genotypes and corresponding $H_{o}$ could influence the estimated $N_{e}$. Therefore, the final $N_{e}$ and its regression against the germination percentage were calculated based on the haploid pollen contribution to the embryo genotypes, giving an estimate of the effective pollen population size $\left(N_{e(P)}\right)$. Less than 20 seeds were available for genotyping and subsequent analysis for five families, therefore the $N_{e(P)}$ of these half-sib families with fewer full seeds might be negatively biased. Rarefaction resampling to a sample size of ten with replacement and recalculating $N_{e(P)} 10,000$ times was used to adjust to uneven sample size. Hence, the mean rarefied effective pollen population size $\left(N_{e(P ; r)}\right)$ was used as the unbiased estimator. Moreover, half-sib family 1 was excluded from subsequent calculation of the regression due to the very low sample size.

The triadic likelihood relatedness ( $r$ ) estimate [30] was calculated using the R-package related v.0.8 [31] as a measure of pairwise relatedness among embryos and as a mean relatedness within half-sib families calculated by averaging pairwise $r$-values for all embryos from the same half-sib family. Linear regression of relatedness against the germination percentage was calculated. To verify relatedness estimates and the linear regression, $r$-values were additionally calculated by the efficient method-of-moment [32] and dyadic likelihood estimates [33] and processed as described above. Further, each algorithm was run with different reference allele frequencies. As all the $r$-estimators used here rely on the sample allele frequency, the sensitivity of the $r$-estimates was assessed by using different allele frequency estimates. First, the default setting was used which calculates population allele frequencies from the individuals of which the $r$-values should be estimated, this corresponds to only the embryo genotypes. In this default calculation the maternal alleles are overrepresented in the allele frequency estimates, because in each half-sib family half the alleles originate from the corresponding maternal tree. This can reduce diversity of the estimated population allele frequency compared to estimates made from stand data, and thus might influence the pairwise $r$-estimates. Therefore, as a second calculation, the frequencies were estimated from the combined embryos and adult trees in the stand and, third, based on the adult trees only. After evaluating the robustness of the method, the rarefied triadic likelihood relatedness $\left(r_{(r)}\right)$ estimate was calculated by rarefaction resampling to a sample size of ten with replacement and recalculating the within family mean over 10,000 replications. As the mean relatedness is calculated from the pairwise estimates, which are largely unaffected by sample size, rarefaction was used to assess the variation of the mean estimate due to different combinations of seeds in a single half-sib family. Also, regression was calculated excluding family 1 . For both regressions of $r_{(r)}$ and $N_{e(P ; r)}$ with the germination percentage as response, respectively, the assumption of normality 
and homogeneity of the residual variances was checked. Box-Cox transformation was applied to validate results, if one of the assumptions was not met.

Resampling with replacement was chosen in order to take into account also families with lower sample size. However, this inevitably implicates drawing identical genotypes for the calculation, which could lower the diversity of the rarefied sample, thus leading to lower estimates of $N_{e}(P ; r)$. Therefore, the rarefaction without replacement was additionally calculated. For the estimate of mean $r$-values it is however irrelevant weather it is calculated by the mean of the original pairwise values or by resampling, either with or without replacement, as the results are identical. Resampling in this case is an approximation of the actual mean value, with increasing iterations approaching it. Yet, the resampling gives additional information on the standard deviation.

Potential pollen donors were assigned by two approaches: (1) a match/no-match comparison between genotypes and (2) using CERVUS v.3.0.7 software [34].

First, we compared the paternal haplotype in the respective embryo to all corresponding genotypes in the sample population at all genotyped markers. Those trees that had no mismatch with the inferred pollen haplotypes were considered as potential paternal trees. To account for potential genotyping errors, a less strict assignment was also performed by allowing a single mismatch only for one of the markers. Trees with only a single mismatch were considered as potential pollen donors, if no other trees with complete matching genotype were found.

Second, CERVUS v.3.0.7 was used with default settings to assign paternal parents. Unfortunately, this programme cannot use paternal haplotype data inferred from the embryo genotypes directly. We solved this problem by forcing the programme to use specifically only these data by replacing maternal haplotypes in diploid embryo genotypes by dummy alleles that are not present in the studied sample. All embryos had the same dummy "maternal" allele at each locus that was also present in only one artificially added dummy mother tree. This approach allowed us to identify the most likely paternal trees for embryos based on the paternal haplotype of these embryos. The cases, in which a paternal tree was also a true maternal parent of an embryo, represented tentative self-pollination.

Pollen dispersal can be described by the distance and geographic direction between the assigned potential pollen donor and the mother tree. Geodesic distances were based on the WGS 84 (EPSG: 3857) point coordinates for trees and calculated using the R-packages rgdal v.1.3-6 [35] and geosphere v.1.5-7 [36]. The direction of pollen dispersal was calculated as the angle between the point coordinates of the maternal tree and the putative pollen donor. For graphical representation all mother trees were projected to a single point, and direction and distance to all putative pollen donors was plotted with the R-package plotrix v.3.7-4 [37]. Dispersal distance was also visualised as frequency histogram in 10-m. distance classes. In cases where no potential pollen donor could be identified without mismatch and more than one potential pollen donor was identified by accepting a single mismatch, the tree with the shortest distance to the mother tree was considered as the most likely candidate pollen donor. In the CERVUS assignment, two confidence thresholds of $95 \%$ (strict) and $80 \%$ (relaxed) were considered.

Simulations were used to compare the observed distances and directions of pollen-dispersal with those expected under complete random mating without assumptions. The 21 mother trees were computationally resampled 20,000 times, pollen donors from the studied stand were randomly assigned, and distances and angles were calculated. Distributions of simulated and observed distances and angles were compared by a two-sample Kolmogorov-Smirnov test. Both the strict and relaxed assignments with $80 \%$ confidence for CERVUS and allowance of one mismatch in the genotype matching approach were used, respectively.

\section{Results}

Germination percentage varied considerably among half-sib families (Table 1). From $3.6 \%$ to $61.9 \%$ of the 84 seeds per tree showed at least a dehisced seed coat after 10 days, with an average of $38.5 \%$ for all seeds. $H_{o}$ and $H_{e}$ ranged from 0.517 to 0.713 and from 0.500 to 0.640 in half-sib families (Table 1). $F_{I S}$-values were negative $(-0.006$ to -0.122$)$ in all half-sib families except for family 15 (0.024) 
and significant in 11 families (Table 1). Comparing the $H_{\mathrm{e}}(0.724)$ estimated based on all 200 trees in the stand to the $H_{\mathrm{o}}(0.613)$ of the pooled seed sample, seeds showed a considerable loss in heterozygosity. In addition, $H_{\mathrm{e}}(0.696)$ compared to $H_{\mathrm{o}}$ of the pooled seed sample (0.607) showed lower heterozygosity. $N_{e}(P ; r)$ varied from 1.1 to 3.7 in the half-sib families and equalled 85.3 for the pooled genotyped seeds (Table 1). The within families mean rarefied triadic likelihood $r_{(r)}$-estimates varied from 0.11 to 0.33 , with a combined mean of 0.22 (Table 1 ). For estimating relatedness within the half-sib families two related methods and two additional population allele frequency estimates were investigated to assess robustness of the reported values. The calculations of the triadic likelihood estimate based on allele frequencies of combined embryo and stand data and stand-only data produced similar and slightly higher mean $r$-values of 0.22 and 0.24 , respectively, compared to the default calculation using only the embryo data. Using the same algorithm with the different reference allele frequencies resulted in significantly correlated estimates. Comparison of different algorithms using the same reference allele frequencies demonstrated also significant correlations between them, except for comparisons of the efficient method-of-moment estimates based on the stand allele frequencies to the two other estimates (Table S4).

A highly significant $(p=0.005)$ negative linear relationship was found between $r_{(r)}$ (Figure 2a), as well as a highly significant $(p=0.003)$ positive relationship between $N_{e}(P ; r)$, calculated with replacement, and germination percentage in the half-sib families. This relationship was still significant $(p=0.02)$ for the rarefied calculation without replacement (Figure 2b). Assumptions of normality and homogeneity of variances of the residuals were tested by QQ-plots (Figure S1) and the Breusch-Pagan [38] test, respectively. Residuals met the assumption for $N_{e(P ; r)}$, but for $r_{(r)}$ the Breusch-Pagan test indicated heterogeneity of variances. To confirm the regression result, it was recalculated with a Box-Cox transformation of $r_{(r)}$, which met both the assumption of normality and variance homogeneity of the residuals. A significant relationship with germination rate was confirmed with an adjusted $R^{2}$ of $0.24(p=0.015)$. Results of the unrarefied values are presented in Figure S2. A significant negative relationship was confirmed for the original data with all methods for calculating $r[30,32,33]$ and applying the described population reference allele frequency estimates, except for the efficient method-of-moment algorithm based on the stand only data (Table S5). Linear regressions between the time and percentage of germination against $H_{o}$ at typed loci were insignificant. As well as no significant influence of $F_{I S}$ on the germination percentage or the dispersal distance of assigned pollen donors was found. Finally, no significant relationship was found between outbreeding and germination rates.

The PCoA plot demonstrates variability of genetic distances between embryos within half-sib families, as well as variability of genetic distance between half-sib families and the stand (Figure S2). Highest within family distance between embryos was found in families 2, 10, 16, 18, and 19, while others showed less genetic distance, especially in families 7 and 17. Families 14, 15, 16, 19, and 20 represented the stand relatively well in terms of variation and coverage, whereas families $2,4,11,12$, and 21 showed more differences to the overall stand. Nevertheless, samples of half-sib families always overlapped partially with the stand data (Figure S3). 

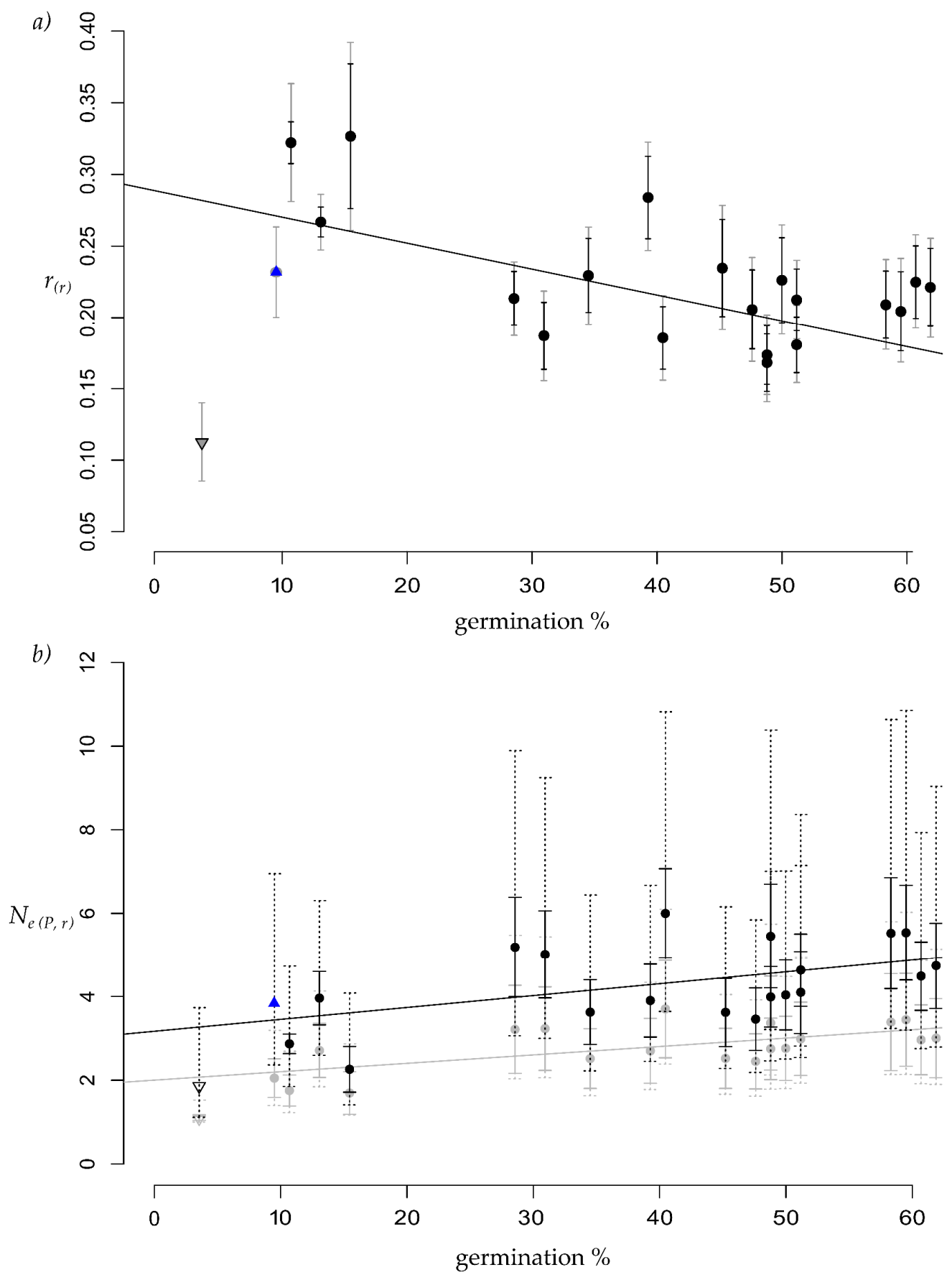

Figure 2. Scatter plot of mean seed germination percentage (x-axis) in 21 half-sib families plotted against the (a) rarefied mean within half-sib family relatedness $\left(r_{(r)}\right)$ or $(\mathbf{b})$ rarefied mean effective pollen population size $\left(N_{e}(P ; r)\right)$ of the half-sib families. The line represents the corresponding linear regression trendline, excluding family 1 (downward triangle) due to very limited sample size. Grey symbols and lines correspond to rarefaction with replacement, black indicates rarefied results without replacement. (a) adjusted $R^{2}=0.33, p=0.005$; (b) with replacement adjusted $R^{2}=0.37, p=0.003$, without replacement adjusted $R^{2}=0.21, p=0.02$. Whiskers represented by solid lines in $(\mathbf{a}, \mathbf{b})$ show the standard deviation of the mean from the rarefaction resampling, whiskers represented by doted lines in (b) shown the mean confidence interval. Indicated by an upward triangle is the unrarefied value for family 13 , because resampling in this family was impossible for rarefaction without replacement.

For the combined results of the assignments without and with one mismatch together the proportion of immigrant pollen was $75.8 \%$ with 92 assignable local pollen donors in 375 genotyped 
seeds. Three self-pollination events were found among 375 mating events in the assignment without and with one mismatch, leading to an estimated self-fertilisation rate $s$ of $0.8 \%(3 / 375)$. One potential pollen donor could be assigned with no mismatch for 32 unique mating events. This corresponds to $8.5 \%$ of all genotyped seeds or an estimated $91.5 \%$ of immigrant pollen, respectively. One self-pollination event without mismatch was detected for 32 mating events $(s=1 / 375$ or $0.3 \%$ ) (Table 1$)$. Dispersal distance for outcrossing ranged from 3 to $138 \mathrm{~m}$ with a mean of $33 \mathrm{~m}$. Potential pollen donors could be assigned for additional 60 seeds by accepting a single mismatch. For 18 of these seeds, more than one potential pollen donor was assigned. Considering only mating with the shortest distance between seed parent and pollen donor for these 18 cases, the mean dispersal distance was $66 \mathrm{~m}$ (ranging from 5 to $161 \mathrm{~m}$ ) for outcrossing. Pollen dispersal was mainly realised within $10 \mathrm{~m} \mathrm{(47 \% )}$ and 10-20 m (19\%) distances when the strict assignment was used. If mating assignments with a single mismatch are also included and considering among multiple possibilities only events with the shortest distance between parents, pollen dispersal within $10(18 \%)$ and 10-20 (12\%) m distances was still the most frequent. A more homogeneous distribution of dispersals was observed for more distant classes, up to the 130-140 m class. In the simulated random mating without any assumptions, dispersal distances reached up to $250 \mathrm{~m}$. with the far-reaching upper tail representing very rare dispersal events. Most simulated dispersal events ( $28 \%$ in total) occurred within 30 to $60 \mathrm{~m}$ distance classes. Shorter distance classes were much less represented for dispersal events than in the observed data (Figure 3a). Dispersal directions were mainly from northern pollen donors southward. Pollen flow north to north-westwards also occurred, but less than the southward dispersal, and distances were much shorter than the possible distances under the simulation. Almost no pollen came from north eastern to south eastern trees (Figure S4a). These directions represent only the observable pollen dispersal based on the genetic assignment; pollen flow from outside this stand is unknown in terms of distance and direction.

Candidate pollen donors were assigned for 112 seeds by CERVUS with relaxed confidence, giving an immigrant pollen estimate of $70.1 \%$. They included 33 assignments with the strict confidence threshold. For eight seeds their true mother tree was assigned as candidate pollen donor, meaning eight self-pollination events for 375 mating events in total ( $s=8 / 375$ or 2.1\%) (Table 1). In total, 30 assignments were detected by both assignment methods, CERVUS and comparison, both with the less strict criteria. Most dispersal occurred within distances up to $20 \mathrm{~m}$ in assignments detected by CERVUS with either relaxed or strict criteria. The distance class up to $10 \mathrm{~m}$ comprised $19.6 \%$ and $39.4 \%$ of assigned mating events under the strict and relaxed criteria, respectively. For the 10-20 m distance class $18.8 \%$ and $25.2 \%$ of assigned mating events were observed, respectively. The mean distance between seed parent and putative pollen donor was $47 \mathrm{~m}$ under the strict criterion, but $169 \mathrm{~m}$ under the relaxed one (Figure 3b). Long distance mating events occurred mainly between a pollen donor located south and the southeast mother tree, but some pollen came from the northern pollen donors. The assignments by CERVUS also included pollen donors from northeast and southeast (Figure S4b), although again gene flow distances and directions for outside pollen could not be characterised.

Distributions of the simulated distances and directions (angles) differed significantly $(p<0.0001)$ from the observed distributions, except for the distribution of pollen dispersal directions (angles) in the CERVUS assignments with relaxed confidence threshold. Estimates of external pollen from the "putative maladapted gene pool" accounted for $70.1-91.5 \%$ of viable embryos, depending on the method of assignment. 
a)

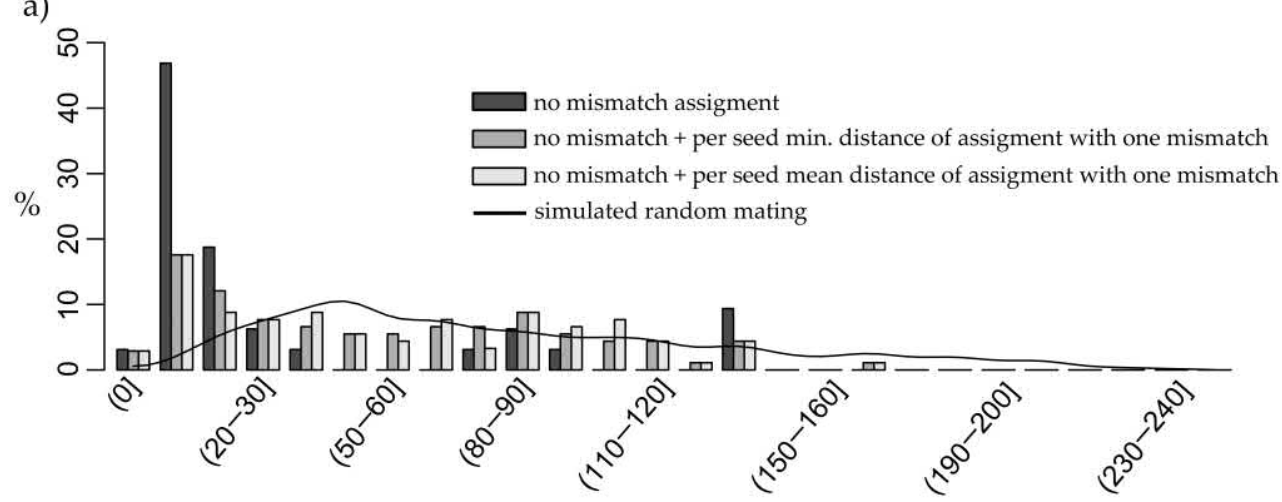

b)

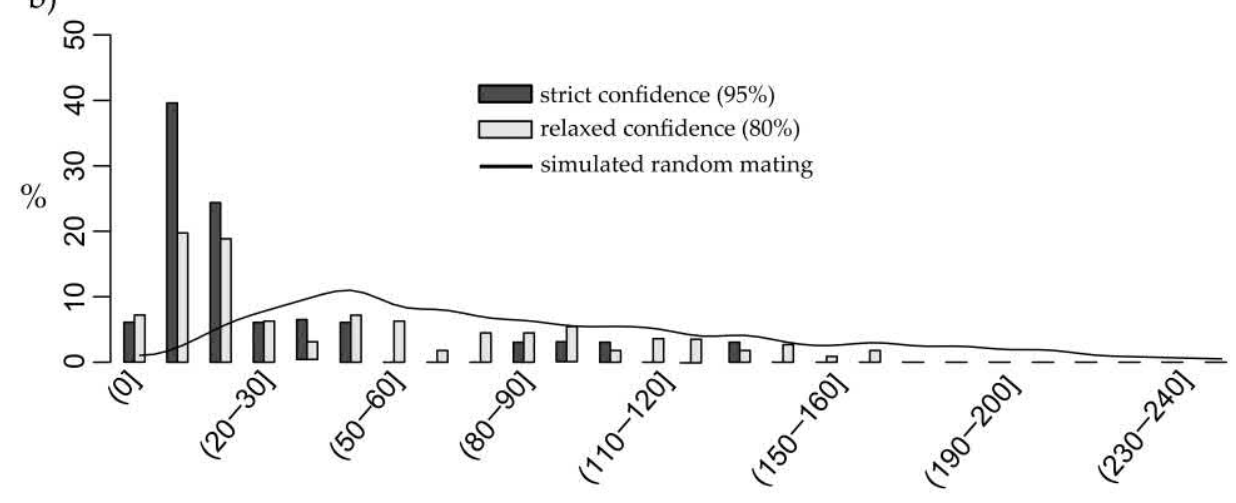

Distance classes [m]

Figure 3. Relative frequency of local, within the stand, pollen dispersal in $10 \mathrm{~m}$. distance interval classes and the $0 \mathrm{~m}$ distance class indicating self-fertilisation: (a) dark grey bars represent strict assignments without any mismatch at the genotyped simple sequence repeat (SSR) markers, grey bars represent strict assignments combined with assignments allowing for only one mismatch, where in cases of multiple possible assignments for a seed the nearest pollen donor was considered, and light grey bars represent the same conditions as previous, but mean distance is used in cases of multiple assignments; (b) dark and light grey bars represent assignments made by CERVUS 3.0.7 with 95\% and 80\% confidence, respectively. The simulated random mating distance of the sampled mother trees and the reference population is given as cubic spline interpolated black curve of 20,000 events. Both observed and simulated data do not include pollen flow from outside the stand.

\section{Discussion}

\subsection{Germination and Relatedness}

The observed mean germination percentage of $38.5 \%$ was relatively low compared to typical commercially available seeds. Although, reported germination percentage may greatly vary depending on year, location, and tree, germination is drastically reduced in selfed seeds $[11,39]$. The seeds used in our study were not commercially processed, and, thus, empty seeds were still present in the sample. Among seeds from five half-sib families, more than $75 \%$ were empty, and fewer than 20 full seeds were available for analysis. Factors that may increase the formation of empty seeds are, amongst others, lack of or insufficient pollination and unsuitable environmental conditions during seed maturation. Nonetheless, inbreeding is the main cause of empty seeds and attributed to increased homozygosity and resulting expression of deleterious recessive alleles, as shown for different spruce species [10,39-42] and other conifers [43-45]. The higher proportion of empty seeds is thus likely caused by selfing and inbreeding but cannot be confirmed by genetic analyses because postzygotic abortion leaves no material to study.

An increase in $r_{(r)}$ and $N_{e(P ; r)}$ estimates within the half-sib families revealed significant negative and positive associations with the germination percentage, respectively. Half-sib families with the 
highest proportion of empty seeds and low germination, showed $N_{e}$ values below, and within family $r$-values above the mean (Figure S2). Because of the high proportion of empty seeds, it was not possible to achieve the sample size of 20 genotyped seeds in these families. Therefore, rarefaction methods were used to calculate unbiased estimators. In contrast, no significant association of diversity $\left(H_{0}\right)$ and fixation index $\left(F_{\mathrm{IS}}\right)$ with the germination time and percentage were detected. Although, a slight trend of positive correlation of higher $H_{o}$ with germination percentage was observed, it was insignificant. Only in four families a slightly increased homozygosity was found within the half-sib families, when $H_{o}$ and $H_{e}$ were compared. For the complete seed lot, increased homozygosity was more pronounced. Distribution of samples in the PCoA also demonstrates a restricted genetic diversity and higher similarity within half-sib families. Genetic load could not be accurately determined because only viable embryos were screened. Thus, genetic diversity parameters in half-sib families with high proportion of empty seeds could be overestimated. However, negative associations of $r_{(r)}$ were observed with $N_{e(P ; r)}$ and germination. The $N_{e(P ; r)}$ estimates, however, should be interpreted with caution, as this method is strongly influenced by sample size. A sample size of 20 and subsequent reduction to 10 for the rarefaction for estimating population size from genotypic data is quite low and combined with a relative high uncertainty of the estimate given by the confidence interval. Higher confidence for the present data is unlikely be achieved with 20 true samples for each family, because even for the complete seed lot of 375 samples, the confidence interval of the estimated total pollen population size was still very broad $-38 \%$ and $87 \%$ of the estimate, respectively.

To explain differences between the half-sib families in $H_{0}, r_{(r)}$ and $N_{e(P ; r)}$, different levels of inbreeding are conceivable, but could not be confirmed. The differences can probably be explained by a limited number and/or diversity of the pollen donors contributing to the single half-sib-families. No family structure was found in the stand: differentiation and relatedness between adult trees did not depend on geographic distance. The pooled progeny was fathered to a large extent by immigrant pollen (70.2\% to $91.5 \%$ dependent on the method), likely from the surrounding planted stands. Thus, increase relatedness estimates cannot be explained only by mating between close relatives. Low diversity of the pollen donors can also result in lower genetic diversity, higher genetic similarity, and increased homozygosity in a half-sib family. This could also lower population size estimates and increase relatedness estimates in the progenies. Thus, a restricted number of, or lower genetic diversity amongst pollen donors likely affected the offspring of a single tree. This is also a plausible explanation for the lower germination, as fitness and variability are associated with genetic diversity in forest trees [46]. Such correlation between poorer seed performance and restricted population size was previously detected in other conifers [47,48]. For example, increased formation of empty seeds and lowered germination rate dependent on population size had been found in artificial Douglas-fir (Pseudotsuga menziesii [Mirbel] Franco) stands of different size [47], and decreased germination and seedling performance dependent on population size were observed in the tropical pine Pinus chiapensis [MARTÍnez] AndREsen [48]. In both cited studies the population size was calculated from census data of the parental population, whereas here it was estimated from genetic data of the pollen haploid contributions to the embryos. We showed that although the studied stand was located within a relatively large spruce area with a supposedly large census, the effective pollen population size varied in the families and affected their germination percentage.

In future studies the effect of pollen immigration on fitness traits, such as germination percentage, should be investigated in detail. The overall low germination performance in combination with the detected high proportion of immigrant pollen of likely different origin from the planted surrounding stands could hint to outbreeding depression. The reduction in fitness traits is caused by cross fertilisation of genetic distant gene pools, when the breakdown of adaptive gene complexes outweighs positive introgression effects [49]. Outbreeding depression was shown to reduce fruit set and seedling number in the flowering plant Acmispon glaber [Vogel] Brouillet. High seed abortion in cross- and naturally pollinated seeds of Pinus sylvestris L. was also explained by outbreeding depression [50]. Similar to inbreeding depression, outbreeding depression also has a long-term effect as revealed by poorer 
performance of growth traits in Abies sachalinensis [F. SснмidT] MAsT. progenies [51]. Neverteless, we could not confirm a significant relationship of the half-sib families' individual outbreeding rate and the germination percentage.

However, the overall $N_{e(p)}$-estimate of 85.3 in the pooled seed lot can be interpreted as large enough to contain enough genetic diversity to avoid genetic drift. It is comparable to similar estimates in other studies of P. abies [52] and conifers [53]. A good representation of the stand in the pooled seed lot can also be seen in the PCoA distribution based on the selectively neutral markers (Figure S2), where the pooled seed lot overlaps with the stand samples. Genetic differentiation estimated using selectively neutral markers was in general relatively low between different $P$. abies stands [15]. It was also found in German stands including the one studied here [17]. However, low genetic differentiation at neutral markers did not reflect differentiation at potentially adaptive candidate genes, for which variation was associated with different adaptive morphotypes [4]. Thus, the high amount of immigrant pollen contributing to at least $70 \%$ of the offspring can change allele frequencies at putative adaptive loci. Population structure of the stand was already studied in Caré et al. [17], and neither correlation of genetic differentiation with distance among individuals nor significant within population genetic structure were found. Here, we studied correlation of $r$ with distance among individuals, and no significant correlation was found.

\subsection{Distances and Distribution}

We observed distance-dependent mating within the stand with closer growing trees being more likely to mate. Within the investigated stand, mating events were most frequent per distance class in $>0 \mathrm{~m}$ to $10 \mathrm{~m}$ and $10 \mathrm{~m}$ to $20 \mathrm{~m}$, but can be as distant as $170 \mathrm{~m}$. This is in agreement with previous results $[6,54]$ and observations on the distance-dependency of single tree pollen cloud density [55]. A directionality in pollen dispersal departing from the simulated random dispersal within the stand could not be conclusively defined because comparisons between simulated and observed distributions were inconsistent, and their significance depended on the method and confidence thresholds.

This distance-dependent mating success applies only to the local pollen and accounts for $~ 10-30 \%$ of the total seeds studied. Exponential decrease in mating probability in the present study was mostly shown at a local scale. Here, "local" refers to the sampled stand, to which an assignment is possible. As the area is continuously covered by spruce trees, mating of the trees on the edge of this stand is expected to happen also with neighbouring trees that will be characterised as immigrant pollen even though it could result from a short distance mating. Nevertheless, a large proportion of pollen likely came from distant pollen sources as previously shown [5,6]. For trees within the centre of the stand, more potential pollen donors were assigned in both approaches than for those growing at the stand edge. This might be partly an effect of the sampling design, since central trees were surrounded by more genotyped trees as compared to trees growing on the edge of the sampled stand. Nevertheless, this indicated that immigrant pollen from the surrounding stands contributed less to the progeny of the central trees, and a considerable amount of within stand mating for central trees is realistic. Moreover, for single mother trees, a maximum of no more than half of the seeds were assigned to potential pollen donors in the studied stand. These results further underline the high proportion of immigrant pollen also for single trees, with as high as $100 \%$ in family 4 .

\subsection{Selfing and Outcrossing}

Estimated effective selfing rates in viable seeds ranged from $0.3 \%$ to $2.1 \%$. This is on the lower end compared to the reported mean values of generally low selfing rates in P. abies [5,6,56-59]. Nevertheless, although rarely, but $100 \%$ outcrossing [58] or high selfing rates greater than $20 \%$ were also observed [59]. Nonetheless, genetic studies of the mating system require "full" seeds. Therefore, estimates of selfing and outcrossing could be biased for seed lots with empty seeds resulted from postzygotic abortion due to possible inbreeding depression [60]. This mechanism of avoiding high self-fertilisation rates 
in the viable offspring in the absence of self-incompatibility mechanisms has also been observed in P. omorika [42].

Approximately two thirds of the estimated outcrossing was due to immigrant pollen most likely coming from the neighbour largely supposedly planted stands. Thus, a negative effect on the genetic composition at adaptive genes is likely. Particularly considering adaptive genetic differences that had been found between different morphotypes in Norway spruce [4].

\section{Conclusions and Perspectives}

Association between $r_{(r)}$ and $N_{e(P ; r)}$ of single tree progenies and fitness represented by germination was shown for seeds collected from a natural population after a partial mast year. Progenies with lowered germination percentage had also lower $N_{e(P ; r)}$ but increased mean $r_{(r)}$. This can be explained by lower genetic diversity in these progenies due to probably a limited number of pollen donors and/or their low diversity. Inbreeding depression expected from mating amongst close relatives and high selfing rates was not found, despite high amounts of empty seeds. This can be an artefact explained by postzygotic abortion of inbred embryos that results in empty seeds as reported for several conifers $[43,45,50]$, but these empty seeds cannot be genetically studied. Further, we estimated that at least $70 \%$ of viable seeds were formed by immigrant pollen. This likely alters the genetic composition of the progeny in this locally adapted stand. As the immigrant pollen was most likely contributed by the surrounding planted spruce stand, representing most likely a distant gene pool, potentially outbreeding depression might both contribute to empty seeds and poor seed fitness. To quantitatively assess these impacts, further studies on seed lots including putative adaptive candidate genes are necessary. To confirm outbreeding depression, controlled crosses or at least sampling the surrounding stands and observing seedling development would be necessary.

For natural regeneration the high amounts of immigrant pollen are likely to alter genetic composition of the stand over generations. As seeds also have a distance-dependent dispersal, and less immigrant pollen contributes to the progeny of central trees, decrease of adaptation is likely happening faster at the edges than in the centre of the stand. Still, dilution of adaptive variation in the stand is a conceivable long-term process in the absence of other effects. Here, the actual regeneration should be studied, as natural selection might counteract the alteration of adaptive variation by immigrant pollen. Also, here we investigated one seed year. As natural regeneration is formed with contributions of several seed years, where the genetic structure of the progeny and mating system parameters vary between years, the amount of immigrant pollen might be differently estimated based on young trees.

It can be expected, that harvesting seeds predominantly in the centre of the stand would retain the most adaptive variation of the stand itself. Still, for a seed harvest equal representation of mother trees in the seed lot is advised, as this also guaranties the maintenance of genetic diversity to avoid introduction of drift effects, since diversity and genetic distance are highly variable between half-sib families. Still, the overall high amount of immigrant pollen is troublesome in the context of preservation of genetic composition of the parental stand.

Supplementary Materials: The following are available online at http://www.mdpi.com/1424-2818/12/7/266/ s1, Document (pdf; 5 pp) including Table S1: SSR markers used for genotyping 200 adult trees including 21 seed-collected trees, embryos, and megagametophytes (Caré et al. [17], modified), Table S2: Concentration (ci, $\mu \mathrm{M} / \mu \mathrm{L}$ ) of each forward and reverse primer in the multiplex reactions (Caré et al. [17], modified), Table S3: PCR touch-down protocol used for amplification of SSR-markers, Table S4: Pearson's correlation coefficient (PCC) for the comparisons ( 1 vs. 2) of mean within half-sib families relatedness estimated with different algorithms and reference allele frequencies, Table S5: Adjusted $\mathrm{R}^{2}$ of linear regressions between the germination percentage and the mean within family relatedness estimated with different algorithms and reference allele frequencies from the original data, excluding half-sib-family 1 due to very limited sample size, Figure S1: Quantile-Quantile diagram of the standardised residuals in the linear regression between within half-sib family seed germination rate presented in Figure 3 and (a) rarefied mean relatedness or (b) rarefied mean effective pollen population size, Figure S2: Scatter plot of mean seed germination rate (y-axis) in 21 half-sib families plotted against the (a) mean within half-sib family relatedness $(r)$ or $(b)$ effective population size $(\mathrm{Ne})$ of the half-sib families. The black line represents the corresponding linear regression trendline: (a) adjusted $R^{2}=0.34, p=0.004$ excluding half-sib family 1 (depicted by the grey cross) due to very limited sample size; (b) adjusted $R^{2}=0.15, p=0.046$, Figure S3: 
Principal Coordinate Analysis (PCoA) of embryos and also adult trees that represent potential pollen donors in the stand based on the pairwise Hamming distance [25] between them calculated using genotypes of 10 SSR markers. For better visualisation of the embryos belonging to the same half-sib family, the figure presents the same PCoA plot 21 times, but each time with samples of a particular half-sib family highlighted by dark blue dots. Potential pollen donors in the stand are highlighted by turquoise, and all other datapoints are highlighted by grey. Distributions of the datapoints that belong to the same half-sib family are circled each by a $95 \%$ inertia ellipse, Figure S4: Local pollen dispersal distances and angles of the assignment determined by (a) matching the pollen haplotype with the genotyped individuals and (b) using Cervus 3.0.7 software. All 21 seed-collected mother trees are projected to the centre of the plot. End-marked lines indicate the assigned pollen donor. (a) A strict assignment with complete match for all markers and allowing a single mismatch for one of the markers are depicted by dark violet lines with round-pointed-ends and blue lines with square-pointed ends, respectively. (b) A strict $95 \%$ confidence delta threshold and a relaxed $80 \%$ confidence delta threshold are depicted by dark violet lines with round-pointed-ends and blue lines with square-pointed ends, respectively. The simulated random mating events $(n=20,000)$ between 21 seed-collected mother trees and all genotyped trees are depicted by light orange lines in the background. Both observed and simulated data do not include pollen flow from outside the stand.

Author Contributions: Conceptualization, O.C., O.G., M.M., K.V.K. and L.L.; methodology, O.C., O.G., M.M., K.V.K. and L.L.; software, O.C.; validation, O.C., O.G., M.M., K.V.K. and L.L.; formal analysis, O.C.; investigation, O.C.; data curation, O.C.; writing—original draft preparation, O.C.; writing—review and editing, O.C., O.G., M.M., K.V.K. and L.L.; visualisation, O.C.; supervision, O.G. and L.L.; project administration, O.G. and L.L.; funding acquisition, O.G., M.M, and L.L. (listed based on position in author list). All authors have read and agreed to the published version of the manuscript.

Funding: This research was funded by the German Federal Ministry of Food and Agriculture (BMEL) represented by the Fachagentur Nachwachsende Rohstoffe e. V. (FNR) grant number FKZ 22023814. The APC was funded by a publication fee waiver granted by MDPI to O.G.

Acknowledgments: The authors thank Alexandra Dolynska, Christine Radler from the Department of Forest Genetics and Forest Tree Breeding, University of Göttingen, for assistance with lab work and ThüringenForst AöR and its staff for help in stand selection. The authors specially thank Chrisitian Rösner from the Forstliches Forschungs- und Kompetenzzentrum (FFK Gotha) for his help with providing the seed samples for this study. The authors also acknowledge the aid in stand selection and permission for the sampling of the adult reference material provided by ThüringenForst AöR. We also acknowledge the three reviewers for their comments that helped us considerably improve the manuscript.

Conflicts of Interest: The authors declare no conflict of interest. The funders had no role in the design of the study; in the collection, analyses, or interpretation of data; in the writing of the manuscript, or in the decision to publish the results.

\section{References}

1. Paul, M.; Hinrichs, T.; Janßen, A.; Schmitt, H.-P.; Soppa, B.; Stephan, R.; Dörflinger, H. Forest Genetic Resources in Germany-Concept for the Conservation and Sustainable Utilization of Forest Genetic Resources in the Federal Republic of Germany; Federal Ministry of Food Agriculture and Consumer Protection (BMELV) in Cooperation with the Federal Government/Länder Working Group “Forest Genetic Resources and Legislation on Forest Reproductive Material" (BLAG-FGR), Ed.; BMELV: Bonn, Germany, 2010.

2. Schmidt-Vogt, H. Taxonomie, Verbreitung, Morphologie, Ökologie, Waldgesellschaften. In Die Fichte-Ein Handbuch in zwei Bänden; Bd. 1.; Parey: Hamburg/Berlin, Germany, 1977; p. 647.

3. Geburek, T.; Robitschek, K.; Milasowszky, N. A tree of many faces: Why are there different crown types in Norway spruce (Picea abies [L.] Karst.)? Flora Morphol. Distrib. Funct. Ecol. Plants 2008, 203, 126-133. [CrossRef]

4. Caré, O.; Gailing, O.; Müller, M.; Krutovsky, K.V.; Leinemann, L. Crown morphology in Norway spruce (Picea abies [KARsT.] L.) as adaptation to mountainous environments is associated with single nucleotide polymorphisms (SNPs) in genes regulating seasonal growth rhythm. Tree Genet. Genomes 2020, 16. [CrossRef]

5. Xie, C.Y.; Knowles, P. Mating system and effective pollen immigration in a Norway spruce plantation (Picea abies). Silvae Genet. 1994, 43, 48-51.

6. Burczyk, J.; Lewandowski, A.; Chalupka, W. Local pollen dispersal and distant gene flow in Norway spruce (Picea abies [L.] KARst.). For. Ecol. Manag. 2004, 197, 39-48. [CrossRef]

7. Williams, C.G. Long-distance pine pollen still germinates after meso-scale dispersal. Am. J. Bot. 2010, 97, 846-855. [CrossRef]

8. Mitton, J.B.; Williams, C.G. Gene flow in conifers. In Landscapes, Genomics and Transgenic Conifers. Managing Forest Ecosystems; Williams, C., Ed.; Springer: Dordrecht, The Netherlands, 2006; pp. 147-168. [CrossRef] 
9. Hagman, M. Incompatibility in forest trees. Proc. R. Soc. London. Ser. B. Biol. Sci. 1975, 188, 313-326. [CrossRef]

10. Mergen, F.; Burley, J.; Furnival, G.M. Embryo and seedling development in Picea glauca (Moench) Voss after self-, cross-, and wind-pollination. Silvae Genet. 1965, 14, 188-194. [CrossRef]

11. Skrøppa, T. Diallel crosses in Picea abies II. Perdormance and inbreeding depression of selfed families. For. Genet. 1996, 3, 69-79.

12. Eriksson, G.; Schelander, B.; Åkerbrand, V. Inbreeding depression in an old experimental plantation of Picea abies. Hereditas 1973, 73, 185-193. [CrossRef]

13. Di-Giovanni, F.; Kevan, P.G. Factors affecting pollen dynamics and its importance to pollen contamination: A review. Can. J. For. Res. 1991, 21, 1155-1170. [CrossRef]

14. Di-Giovanni, F.; Kevan, P.G.; Arnold, J. Lower planetary boundary layer profiles of atmospheric conifer pollen above a seed orchard in northern Ontario, Canada. For. Ecol. Manag. 1996, 83, 87-97. [CrossRef]

15. Tollefsrud, M.M.; Sønstebø, J.H.; Brochmann, C.; Johnsen, Ø.; Skrøppa, T.; Vendramin, G.G. Combined analysis of nuclear and mitochondrial markers provide new insight into the genetic structure of North European Picea abies. Heredity 2009, 102, 549-562. [CrossRef] [PubMed]

16. Krutovsky, K.; Burczyk, J.; Chybicki, I. Gene Flow, Spatial Structure, Local Adaptation, and Assisted Migration in Trees. In Genomics of Tree Crops; Schnell, R.J., Priyadarshan, P.M., Eds.; Springer: New York, NY, USA; Heidelberg, Germany; Dordrecht, The Netherlands; London, UK, 2012; pp. 71-116, ISBN 9781461409199.

17. Caré, O.; Müller, M.; Vornam, B.; Höltken, A.; Kahlert, K.; Krutovsky, K.; Gailing, O.; Leinemann, L. High morphological differentiation in crown architecture contrasts with low population genetic structure of German Norway spruce stands. Forests 2018, 9, 752. [CrossRef]

18. Thüringer Landesamt für Bodenmanagement und Geoinformation (Ed.) Geoportal-Th. Available online: https://www.geoportal-th.de (accessed on 4 May 2020).

19. Scotti, I.; Magni, F.; Paglia, G.P.; Morgante, M. Trinucleotide microsatellites in Norway spruce (Picea abies): Their features and the development of molecular markers. Theor. Appl. Genet. 2002, 106, 40-50. [CrossRef]

20. Pfeiffer, A.; Olivieri, A.M.; Morgante, M. Identification and characterization of microsatellites in Norway spruce (Picea abies K.). Genome 1997, 40, 411-419. [CrossRef]

21. Besnard, G.; Acheré, V.; Rampant, P.F.; Favre, J.M.; Jeandroz, S. A set of cross-species amplifying microsatellite markers developed from DNA sequence databanks in Picea (Pinaceae). Mol. Ecol. Notes 2003, 3, 380-383. [CrossRef]

22. Rungis, D.; Bérubé, Y.; Zhang, J.; Ralph, S.; Ritland, C.E.; Ellis, B.E.; Douglas, C.; Bohlmann, J.; Ritland, K. Robust simple sequence repeat markers for spruce (Picea spp.) from expressed sequence tags. Theor. Appl. Genet. 2004, 109, 1283-1294. [CrossRef] [PubMed]

23. Excoffier, L.; Lischer, H.E.L. Arlequin suite ver 3.5: A new series of programs to perform population genetics analyses under Linux and Windows. Mol. Ecol. Resour. 2010, 10, 564-567. [CrossRef]

24. Paradis, E.; Schliep, K. ape 5.0: An environment for modern phylogenetics and evolutionary analyses in R. Bioinformatics 2019, 35, 526-528. [CrossRef]

25. Hamming, R.W. Error Detecting and error correcting codes. Bell Syst. Tech. J. 1950, 29, 147-160. [CrossRef]

26. Kamvar, Z.N.; Tabima, J.F.; Grünwald, N.J. Poppr: An R package for genetic analysis of populations with clonal, partially clonal, and/or sexual reproduction. PeerJ 2014, 2, e281. [CrossRef] [PubMed]

27. Kamvar, Z.N.; Brooks, J.C.; Grünwald, N.J. Novel R tools for analysis of genome-wide population genetic data with emphasis on clonality. Front. Genet. 2015, 6, 208. [CrossRef] [PubMed]

28. Hui, T.-Y. NB: Maximum Likelihood Method in Estimating Effective Population Size from Genetic Data. R Package Version 0.9. 2014. Available online: https://rdrr.io/cran/NB/ (accessed on 2 May 2020).

29. Hui, T.-Y.J.; Burt, A. Estimating Effective Population Size from Temporally Spaced Samples with a Novel, Efficient Maximum-Likelihood Algorithm. Genetics 2015, 200, 285-293. [CrossRef] [PubMed]

30. Wang, J. Triadic IBD coefficients and applications to estimating pairwise relatedness. Genet. Res. 2007, 89, 135-153. [CrossRef] [PubMed]

31. Pew, J.; Muir, P.H.; Wang, J.; Frasier, T.R. related: An R package for analyzing pairwise relatedness from codominant molecular markers. Mol. Ecol. Resour. 2015, 15, 557-561. [CrossRef]

32. Ritland, K. Estimators for pairwise relatedness and individual inbreeding coefficients. Genet. Res. 1996, 67, 175-185. [CrossRef]

33. Milligan, B.G. Maximum-likelihood estimation of relatedness. Genetics 2003, 163, 1153-1167. 
34. Kalinowski, S.; Taper, M.; Marshall, T. Revising how the computer program CERVUS accommodates genotyping error increases success in paternity assignment. Mol. Ecol. 2007, 16, 1099-1106. [CrossRef]

35. Bivand, R.; Keitt, T.; Rowlingson, B. rgdal: Bindings for the "Geospatial” Data Abstraction Library. R Package Version 1.3-6. Available online: https://CRAN.R-project.org/package=rgdal (accessed on 26 June 2020).

36. Hijmans, R.J. Geosphere: Spherical Trigonometry. R Package Version 1.5-7. Available online: https: //CRAN.R-project.org/package=geosphere (accessed on 26 May 2020).

37. Lemon, J. Plotrix: A package in the red light district of R. R-News 2006, 6, 8-12.

38. Breusch, T.S.; Pagan, A.R. A Simple test for heteroscedasticity and random coefficient variation. Econometrica 1979, 47, 1287-1294. [CrossRef]

39. Andersson, E. Cone and seed studies in Norway spruce (Pices abies (L.) Karst). Studia For. Suec. 1965, $23,214$.

40. Fowler, D.P.; Park, Y.S. Population studies of white spruce. I. Effects of self-pollination. Can. J. For. Res. 1983, 13, 1133-1138. [CrossRef]

41. Coles, J.F.; Fowler, D.P. Inbreeding in neighboring trees in two white spruce populations. Silvae Genet. 1976, 25, 29-34.

42. Kuittinen, H.; Savolainen, O. Picea omorika is a self-fertile but outcrossing conifer. Heredity 1992, 68, $183-187$. [CrossRef] [PubMed]

43. Mullin, T.J.; Persson, T.; Abrahamsson, S.; Andersson Gull, B. Effects of inbreeding depression on seed production in scots pine (Pinus sylvestris). Can. J. For. Res. 2019, 49, 854-860. [CrossRef]

44. Berrill, J.; Libby, W.J. Comparing growth and form of coast redwood selfs and outcrosses. In Coast. Redwood Science Symposium-2016: Past Successes and Future Direction; Standiford, R.B., Valachovic, Y., Eds.; Gen. Tech. Rep. PSW-GTR-258; U.S. Department of Agriculture, Forest Service, Pacific Southwest Research Station: Albany, CA, USA, 2016; pp. 229-240.

45. Woods, J.H.; Heaman, J.C. Effect of different inbreeding levels on filled seed production in Douglas-fir. Can. J. For. Res. 1989, 19, 54-59. [CrossRef]

46. Müller-Starck, G.; Ziehe, M.; Schubert, R. Genetic Diversity Parameters Associated with Viability Selection, Reproductive Efficiency, and Growth in Forest Tree Species. In Forest Diversity and Function; Scherer-Lorenzen, M., Körner, C., Schulze, E.D., Eds.; Springer: Heidelberg, Germany, 2005; Volume 176, pp. 87-108.

47. Wojacki, J.; Eusemann, P.; Ahnert, D.; Pakull, B.; Liesebach, H. Genetic diversity in seeds produced in artificial Douglas-fir (Pseudotsuga menziesii) stands of different size. For. Ecol. Manag. 2019, 438, 18-24. [CrossRef]

48. Del Castillo, R.F.; Trujillo-Argueta, S.; Sánchez-Vargas, N.; Newton, A.C. Genetic factors associated with population size may increase extinction risks and decrease colonization potential in a keystone tropical pine. Evol. Appl. 2011, 4, 574-588. [CrossRef]

49. Lynch, M. The genetic interpretation of inbreeding depression and outbreeding depression. Evolution 1991, 45, 622-629. [CrossRef]

50. Kärkkäinen, K.; Savolainen, O.; Koski, V. Why do plants abort so many developing seeds: Bad offspring or bad maternal genotypes? Evol. Ecol. 1999, 13, 305-317. [CrossRef]

51. Goto, S.; Iijima, H.; Ogawa, H.; Ohya, K. Outbreeding depression caused by intraspecific hybridization between local and nonlocal genotypes in Abies sachalinensis. Restor. Ecol. 2011, 19, 243-250. [CrossRef]

52. Sønstebø, J.H.; Tollefsrud, M.M.; Myking, T.; Steffenrem, A.; Nilsen, A.E.; Edvardsen, M.; Johnskås, O.R.; El-Kassaby, Y.A. Genetic diversity of Norway spruce (Picea abies (L.) Karst.) seed orchard crops: Effects of number of parents, seed year, and pollen contamination. For. Ecol. Manag. 2018, 411, 132-141. [CrossRef]

53. O'Connell, L.M.; Mosseler, A.; Rajora, O.P. Impacts of forest fragmentation on the mating system and genetic diversity of white spruce (Picea glauca) at the landscape level. Heredity 2006, 97, 418-426. [CrossRef] [PubMed]

54. Shimono, A.; Wang, X.R.; Torimaru, T.; Lindgren, D.; Karlsson, B. Spatial variation in local pollen flow and mating success in a Picea abies clone archive and their implications for a novel "breeding without breeding" strategy. Tree Genet. Genomes 2011, 7, 499-509. [CrossRef]

55. Wright, J.W. Pollen Dispersion of Some Forest Trees; Station Paper NE-46; United States Department of Agriculture, Forest Service, Northeastern Forest Experiment Station Upper Darby: Pennsylvania, PA, USA, 1952; p. 42.

56. Finkeldey, R. Homogeneity of pollen allele frequencies of single seed trees in Picea abies (L.) Karst plantations. Heredity 1995, 74, 451-463. [CrossRef] 
57. Pakkanen, A.; Nikkanen, T.; Pulkkinen, P. Annual variation in pollen contamination and outcrossing in a Picea abies seed orchard. Scand. J. For. Res. 2000, 15, 399-404. [CrossRef]

58. Dering, M.; Misiorny, A.; Chałupka, W. Inter-year variation in selfing, background pollination, and paternal contribution in a Norway spruce clonal seed orchard. Can. J. For. Res. 2014, 44, 760-767. [CrossRef]

59. Muona, O.; Paule, L.; Szmidt, A.E.; Kärkkäinen, K. Mating system analysis in a central and northern European population of Picea abies. Scand. J. For. Res. 1990, 5, 97-102. [CrossRef]

60. Rajora, O.P.; Mosseler, A.; Major, J.E. Indicators of population viability in red spruce, Picea rubens. II. Genetic diversity, population structure, and mating behavior. Can. J. Bot. 2000, 78, 941-956. [CrossRef]

(C) 2020 by the authors. Licensee MDPI, Basel, Switzerland. This article is an open access article distributed under the terms and conditions of the Creative Commons Attribution (CC BY) license (http://creativecommons.org/licenses/by/4.0/). 


\subsection{Chapter III-Supplementary Materials}

\section{Mating system in a native Norway spruce (Picea abies [L.] Karst.) stand - Effective population size and relatedness show the tendency of an association with the germination percentage of single tree progenies.}

Oliver Caré, Oliver Gailing*, Markus Müller, Konstantin V. Krutovsky, and Ludger Leinemann

*Correspondence: ogailin@gwdg.de

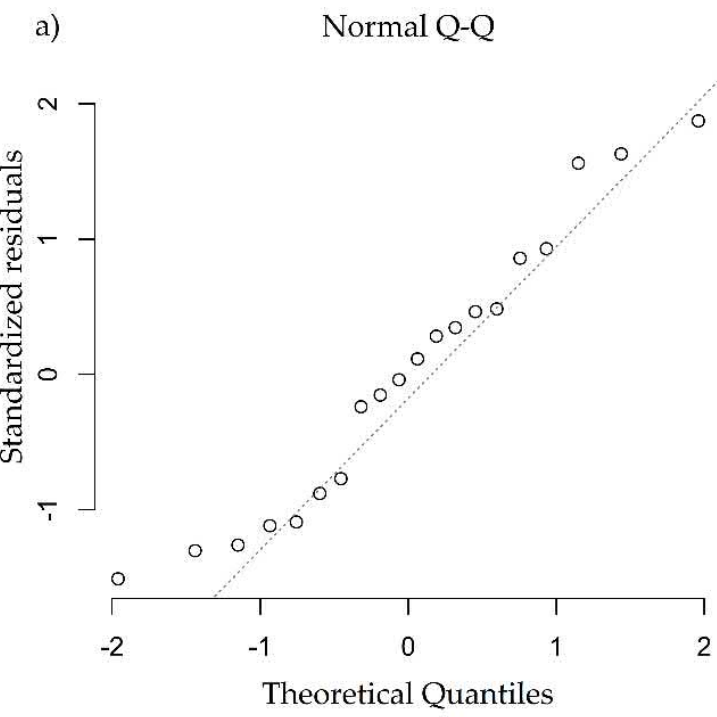

b) Normal Q-Q

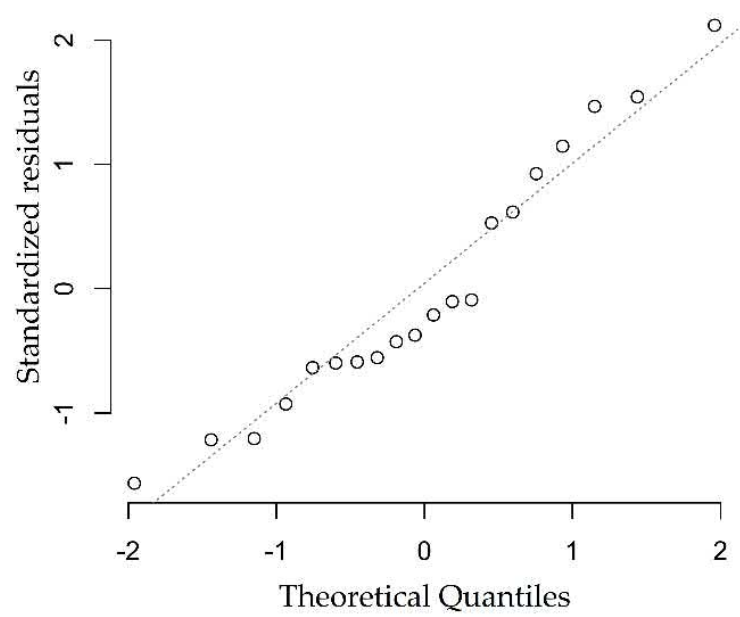

Figure S1. Quantile-Quantile diagram of the standardized residuals in the linear regression between within half-sib family seed germination rate presented in Figure 3 and a) rarefied mean relatedness or b) rarefied mean effective pollen population size. 

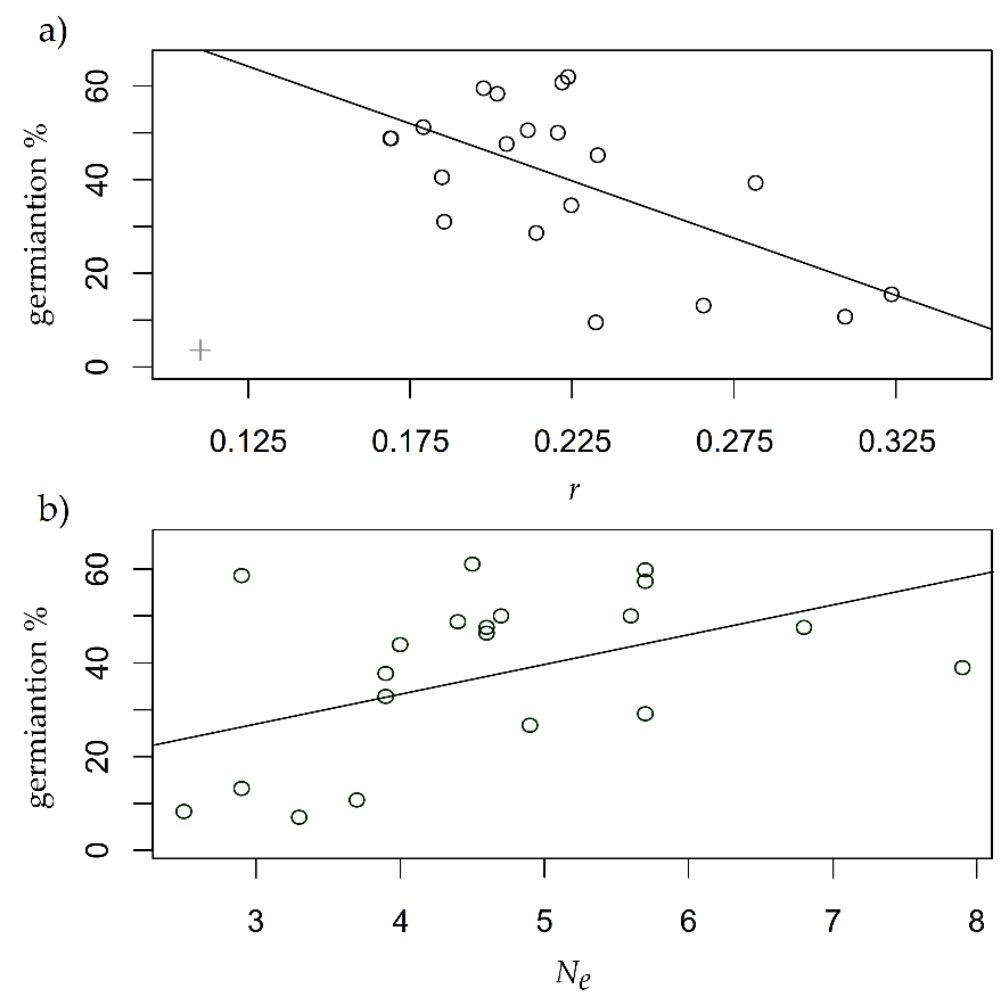

Figure S2. Scatter plot of mean seed germination rate (y-axis) in 21 half-sib families plotted against the a) mean within half-sib family relatedness $(r)$ or $\mathbf{b})$ effective population size $\left(N_{e}\right)$ of the half-sib families. The black line represents the corresponding linear regression trendline: a) adjusted $R^{2}=0.34, P=0.004$ excluding half-sib family 1 (depicted by the grey cross) due to very limited sample size; $\mathbf{b}$ ) adjusted $R^{2}=0.15, P=0.046$ 


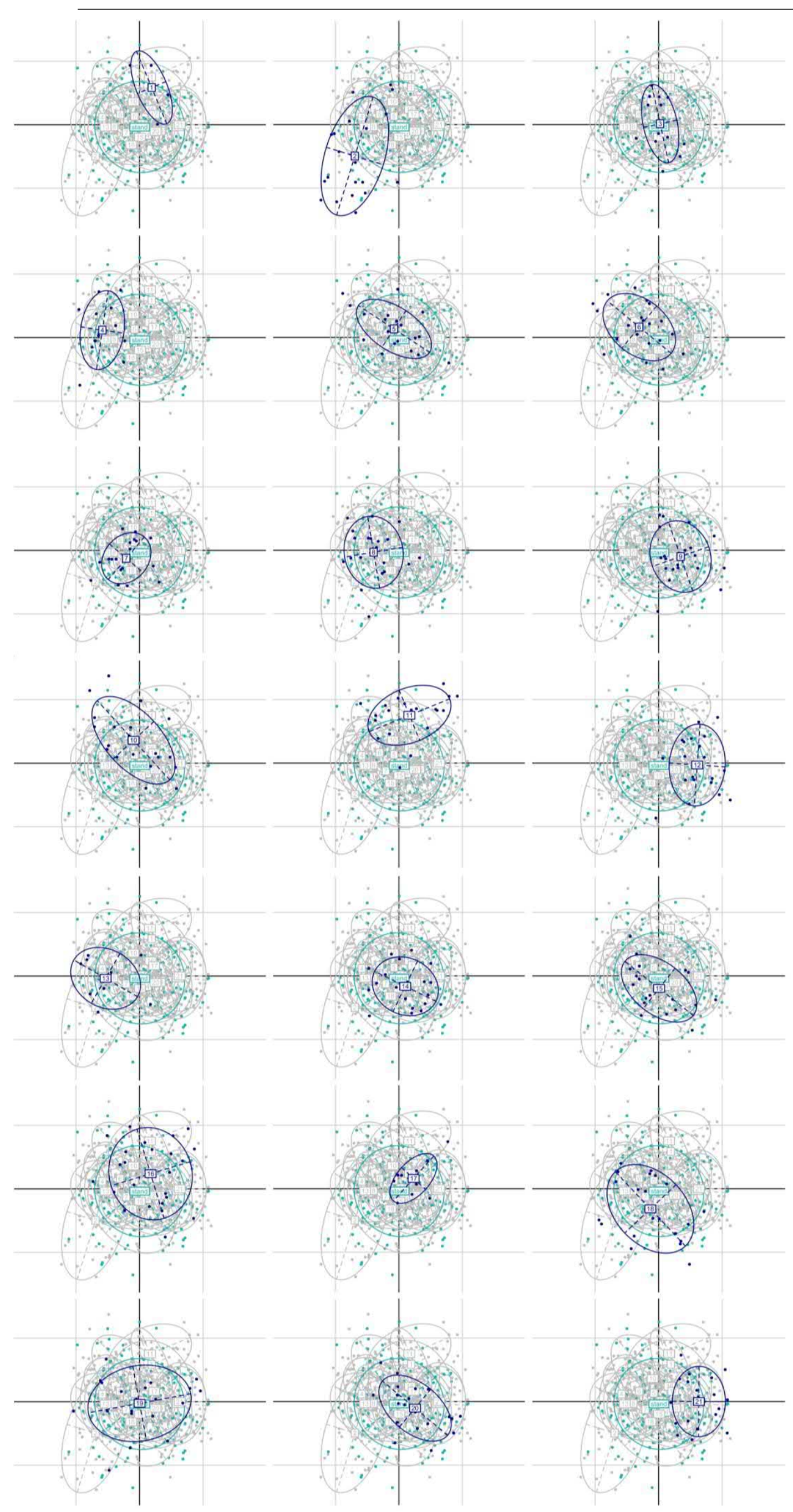

Figure S3. Principal Coordinate Analysis (PCoA) of embryos and also adult trees that represent potential pollen donors in the stand based on the pairwise Hamming distance [24] between them calculated using genotypes of 10 SSR markers. For better visualization of the embryos belonging to the same half-sib family, the figure presents the same PCoA plot 21 times, but each time with samples of a particular half-sib family highlighted by dark blue dots. Potential pollen donors in the stand are highlighted by turquoise, and all other datapoints are highlighted by grey. Distributions of the datapoints that belong to the same half-sib family are circled each by a $95 \%$ inertia ellipse. 
a)

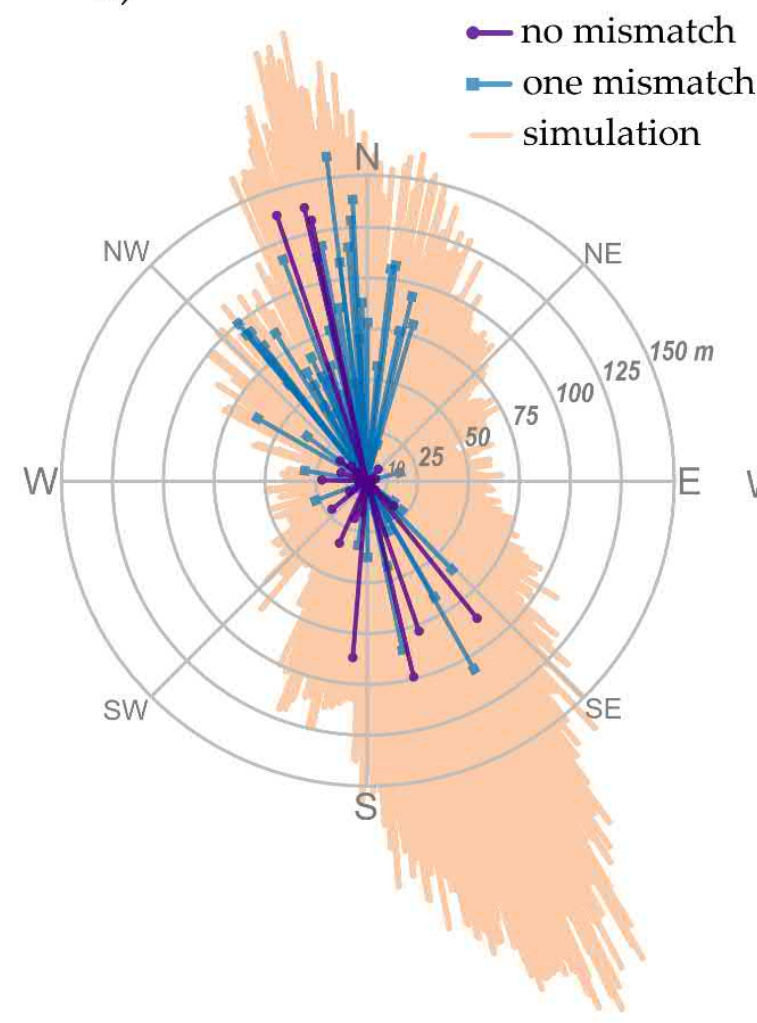

b)

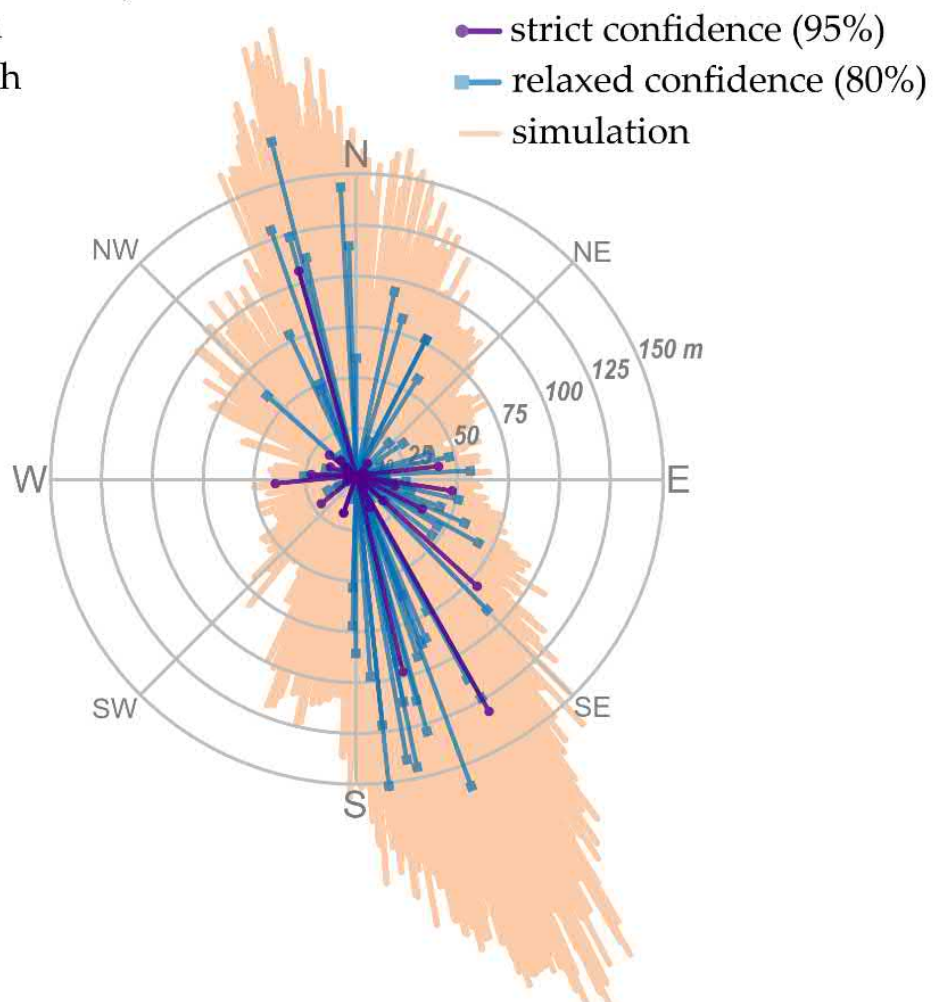

Figure S4. Local pollen dispersal distances and angles of the assignment determined by a) matching the pollen haplotype with the genotyped individuals and b) using Cervus 3.0.7 software. All 21 seedcollected mother trees are projected to the centre of the plot. End-marked lines indicate the assigned pollen donor. a) A strict assignment with complete match for all markers and allowing a single mismatch for one of the markers are depicted by dark violet lines with round-pointed-ends and blue lines with square-pointed ends, respectively. b) A strict 95\% confidence delta threshold and a relaxed $80 \%$ confidence delta threshold are depicted by dark violet lines with round-pointed-ends and blue lines with square-pointed ends, respectively. The simulated random mating events $(\mathrm{N}=20,000)$ between 21 seed-collected mother trees and all genotyped trees are depicted by light orange lines in the background. Both observed and simulated data do not include pollen flow from outside the stand. 
Table S1. SSR markers used for genotyping 200 adult trees including 21 seed-collected trees, embryos, and megagametophytes (Caré et al. [17], modified).

\begin{tabular}{|c|c|c|c|c|}
\hline SSR marker & $\begin{array}{l}\text { Allele } \\
\text { size } \\
\text { range, } \\
\text { bp }\end{array}$ & $\begin{array}{c}\text { Dye label (6-FAM and HEX) and the } \\
\text { forward (F) and reverse (R) PCR primer } \\
\text { nucleotide sequences }\left(5^{\prime}-3^{\prime}\right)\end{array}$ & Repeat motif & Reference \\
\hline EATC1B2a $^{a}$ & $197-219$ & $\begin{array}{l}\text { F: 6-FAM-TGGCATGAGATTTATGTGGTT } \\
\text { R: GTGTGCCACTCAACCTCAC }\end{array}$ & $(\mathrm{ATC}) 7(\mathrm{AT}) 3$ & \multirow{4}{*}{$\begin{array}{c}\text { Scotti et } \\
\text { al. [60] }\end{array}$} \\
\hline EATC1D2a & $180-236$ & $\begin{array}{l}\text { F: 6-FAM-TTGTCATCGTCGTCATTGTC } \\
\text { R: TTTAGCCTCTGTTTTCTAGCG }\end{array}$ & (ATC)3AT(ATC)6 & \\
\hline EATC1E03a & $130-175$ & $\begin{array}{l}\text { F: 6-FAM-CCCCTTATTCCTAACGTCAAA } \\
\text { R: TACCAGTGGTGACAACGATG }\end{array}$ & $\begin{array}{c}\text { (CAT)4CGT(CAT)8CG } \\
\mathrm{T}(\mathrm{CAT}) 4 \mathrm{CGT}(\mathrm{CT}) 4 \mathrm{CG} \\
\mathrm{T}(\mathrm{CAT}) 4\end{array}$ & \\
\hline EATC2G05a & 193-254 & $\begin{array}{l}\text { F: HEX-TGGAGCATGGGTAAATCG } \\
\text { R: TACCTCACACCCGTGAGAAT }\end{array}$ & $\begin{array}{c}(\mathrm{AAT}) 5(\mathrm{CAT}) 16 \mathrm{CAA}( \\
\mathrm{CAT}) 4\end{array}$ & \\
\hline PaGB3 $^{\mathrm{b}}$ & $109-150$ & $\begin{array}{l}\text { F: 6-FAM-AGTGATTAAACTCCTGACCAC } \\
\text { R: CACTGAATACACCCATTATCC }\end{array}$ & (AT)11 & \multirow{2}{*}{$\begin{array}{l}\text { Besnard et } \\
\text { al. [61] }\end{array}$} \\
\hline SpAG2a & $88-122$ & $\begin{array}{l}\text { F: 6-FAM-GCTCTTCACGTGTACTTGATC } \\
\text { R: TTCGAAGATCCTCCAAGATAC }\end{array}$ & (TC)16 & \\
\hline SpAGC1 a & $71-121$ & $\begin{array}{l}\text { F: HEX-TTCACCTTAGCCGAGAACC } \\
\text { R: CACTGGAGATCTTCGTTCTGA }\end{array}$ & (TC)5TT(TC)10 & \multirow{2}{*}{$\begin{array}{l}\text { Pfeiffer et } \\
\text { al. [62] }\end{array}$} \\
\hline SpAGG3a & $109-149$ & $\begin{array}{l}\text { F: HEX-AGCATGTTGTCCCATATAGACC } \\
\text { R: CTCCAACATTCCCATGTAGC }\end{array}$ & $(\mathrm{GA}) 24$ & \\
\hline WS00016.O09b & $386-402$ & $\begin{array}{l}\text { F: HEX-CTTTGGGGGCTAGCAAGTTT } \\
\text { R: ATTCGGGCTTCATAGCACAA }\end{array}$ & $(\mathrm{AT}) 9$ & \multirow{2}{*}{$\begin{array}{l}\text { Rungis et } \\
\text { al. [63] }\end{array}$} \\
\hline WS00111.K13b & $212-272$ & $\begin{array}{l}\text { F: HEX-GACTGAAGATGCCGATATGC } \\
\text { R: GGCCATATCATCTCAAAATAAAGAA }\end{array}$ & $(\mathrm{AT}) 9$ & \\
\hline
\end{tabular}

a gSSRs, ${ }^{\mathrm{b}}$ EST-SSRs 
Table S2. Concentration $(\mathrm{ci}, \mu \mathrm{M} / \mu \mathrm{l})$ of each forward and reverse primer in the multiplex reactions (Caré et al. [17], modified).

\begin{tabular}{cccccccc}
\hline \multicolumn{2}{c}{ Multiplex 1 } & \multicolumn{2}{c}{ Multiplex 2 } & \multicolumn{2}{c}{ Multiplex 3 } & \multicolumn{2}{c}{ Multiplex 4 } \\
\multicolumn{1}{c}{ SSR } & $\mathcal{c}_{\mathbf{i}}$ & SSR & $\mathcal{c}_{\mathbf{i}}$ & SSR & $\mathcal{c}_{\mathbf{i}}$ & SSR & $\mathcal{c}_{\mathbf{i}}$ \\
\hline WS00111.K13 & 3.57 & $S p A G C 1$ & 2.14 & EATC1E03 & 1.25 & $S p A G G 2$ & 1.79 \\
EATC1D2 & 2.14 & $E A T C 2 G 05$ & 2.14 & $S p A G 2$ & 1.79 & $W S 00016.009$ & 3.57 \\
& & $E A T C 1 B 2$ & 1.07 & SpAC1F07 & 3.57 & $P a G B 3$ & 1.07 \\
\hline
\end{tabular}

Table S3. PCR touch-down protocol used for amplification of SSR-markers.

\begin{tabular}{cccc}
\hline Step & Temperature, ${ }^{\circ} \mathbf{C}$ & Time, min & Cycle repeats \\
\hline Incubation & 95 & 15 & 1 \\
& & & \\
Denaturation & 94 & 1 & 10 \\
Annealing & $60(\Delta-1)$ & 1 & \\
Extension & 72 & 1 & 25 \\
Denaturation & 95 & 1 & \\
Annealing & 50 & 1 & 1 \\
Extension & 72 & 1 & \\
Final extension & 72 & 20 & \\
\hline
\end{tabular}


Table S4. Pearson's correlation coefficient (PCC) for the comparisons (1 vs. 2) of mean within half-sib families relatedness estimated with different algorithms and reference allele frequencies.

\begin{tabular}{|c|c|c|c|c|}
\hline \multicolumn{2}{|c|}{ Calculation 1} & \multicolumn{2}{|c|}{ Calculation 2} & \multirow[b]{2}{*}{ PCC } \\
\hline Algorithm 1(1) & $\begin{array}{l}\text { reference allele } \\
\text { frequency } 1^{(2)}\end{array}$ & Algorithm $2^{(1)}$ & $\begin{array}{l}\text { reference allele } \\
\text { frequency } 2^{(2)}\end{array}$ & \\
\hline triadic likelihood & default & triadic likelihood & $\begin{array}{l}\text { stand \& } \\
\text { embryo }\end{array}$ & $0.996 * * *$ \\
\hline triadic likelihood & default & triadic likelihood & stand & $0.979 * * *$ \\
\hline triadic likelihood & $\begin{array}{l}\text { stand \& } \\
\text { embryo }\end{array}$ & triadic likelihood & stand & $0.991 * * *$ \\
\hline $\begin{array}{l}\text { efficient method-of- } \\
\text { moment }\end{array}$ & default & $\begin{array}{l}\text { efficient method-of- } \\
\text { moment }\end{array}$ & $\begin{array}{l}\text { stand \& } \\
\text { embryo }\end{array}$ & $0.956^{* * *}$ \\
\hline $\begin{array}{l}\text { efficient method-of- } \\
\text { moment }\end{array}$ & default & $\begin{array}{l}\text { efficient method-of- } \\
\text { moment }\end{array}$ & stand & $0.734 * * *$ \\
\hline $\begin{array}{l}\text { efficient method-of- } \\
\text { moment }\end{array}$ & $\begin{array}{l}\text { stand \& } \\
\text { embryo }\end{array}$ & $\begin{array}{l}\text { efficient method-of- } \\
\text { moment }\end{array}$ & stand & $0.794 * * *$ \\
\hline dyadic likelihood & default & dyadic likelihood & $\begin{array}{l}\text { stand \& } \\
\text { embryo }\end{array}$ & $0.998 * * *$ \\
\hline dyadic likelihood & default & dyadic likelihood & stand & $0.981 * * *$ \\
\hline dyadic likelihood & $\begin{array}{l}\text { stand \& } \\
\text { embryo }\end{array}$ & dyadic likelihood & stand & $0.992 * * *$ \\
\hline triadic likelihood & default & $\begin{array}{l}\text { efficient method-of- } \\
\text { moment }\end{array}$ & default & $0.692^{* * *}$ \\
\hline triadic likelihood & default & dyadic likelihood & default & $0.983 * * *$ \\
\hline $\begin{array}{l}\text { efficient method-of- } \\
\text { moment }\end{array}$ & default & dyadic likelihood & default & $0.627^{* *}$ \\
\hline triadic likelihood & $\begin{array}{l}\text { stand \& } \\
\text { embryo }\end{array}$ & $\begin{array}{l}\text { efficient method-of- } \\
\text { moment }\end{array}$ & $\begin{array}{l}\text { stand \& } \\
\text { embryo }\end{array}$ & $0.683^{* * *}$ \\
\hline triadic likelihood & $\begin{array}{l}\text { stand \& } \\
\text { embryo }\end{array}$ & dyadic likelihood & $\begin{array}{l}\text { stand \& } \\
\text { embryo }\end{array}$ & $0.988 * * *$ \\
\hline $\begin{array}{l}\text { efficient method-of- } \\
\text { moment }\end{array}$ & $\begin{array}{l}\text { stand \& } \\
\text { embryo }\end{array}$ & dyadic likelihood & $\begin{array}{l}\text { stand \& } \\
\text { embryo }\end{array}$ & $0.632^{* *}$ \\
\hline triadic likelihood & stand & $\begin{array}{l}\text { efficient method-of- } \\
\text { moment }\end{array}$ & stand & 0.4 \\
\hline triadic likelihood & stand & dyadic likelihood & stand & $0.988 * * *$ \\
\hline $\begin{array}{l}\text { efficient method-of- } \\
\text { moment }\end{array}$ & stand & dyadic likelihood & stand & 0.345 \\
\hline
\end{tabular}

(1)triadic likelihood described in [29]; efficient-method-of moment described in [31]; dyadic likelihood described in [32] (2)reference allele frequency used in the calculation; default uses the sample data for estimating the population allele frequency, here the embryo data; stand \& embryo is the combined allele frequencies of the sampled stand and the embryos and stand is the adjusted allele frequencies of only the stand data; $P<0.05,{ }^{* *} P<0.01,{ }^{* * *} P<0.001$. 
Table S5. Adjusted $\mathrm{R}^{2}$ of linear regressions between the germination percentage and the mean within family relatedness estimated with different algorithms and reference allele frequencies from the original data, excluding half-sib-family 1 due to very limited sample size.

\begin{tabular}{|c|c|c|}
\hline Algorithm (1) & $\begin{array}{l}\text { reference } \\
\text { allele } \\
\text { frequency }^{(2)}\end{array}$ & adjusted $R^{2}$ \\
\hline triadic likelihood & default & $0.3435^{* *}$ \\
\hline triadic likelihood & $\begin{array}{l}\text { stand \& } \\
\text { embryo }\end{array}$ & $0.3009^{* *}$ \\
\hline triadic likelihood & stand & $0.2396^{*}$ \\
\hline efficient method-of-moment & default & $0.5326^{* * *}$ \\
\hline efficient method-of-moment & $\begin{array}{l}\text { stand \& } \\
\text { embryo }\end{array}$ & $0.446^{* *}$ \\
\hline efficient method-of-moment & stand & 0.08051 \\
\hline dyadic likelihood & default & $0.2504^{*}$ \\
\hline dyadic likelihood & $\begin{array}{l}\text { stand \& } \\
\text { embryo }\end{array}$ & $0.2137^{*}$ \\
\hline dyadic likelihood & stand & $0.1552^{*}$ \\
\hline
\end{tabular}

(1)triadic likelihood described in [29]; efficient-method-of moment described in [31]; dyadic likelihood described in [32] (2)reference allele frequency used in the calculation; default uses the sample data for estimating the population allele frequency, here the embryo data; stand \& embryo is the combined allele frequencies of the sampled stand and the embryos, and stand is the adjusted allele frequencies of only the stand data; $P<0.05,{ }^{* *} P<0.01,{ }^{* * *} P<0.001$. 


\section{Danksagung (Acknowledgment)}

Ich möchte mich herzlich bei Allen bedanke, die mich währen der Zeit als Doktorand unterstützt haben. Viele haben mich in dieser spannenden und aufregenden Zeit begleitet. Einigen, ohne die die vorliegende Arbeit nicht zustande gekommen wäre, möchte ich hier namentlich Dank aussprechen. Herr PD Dr. Ludger Leinemann möchte insbesondere für das entgegengebrachtes Vertrauen, die Unterstützung und die Freiheit bei der Gestaltung dieser Arbeit danken. Auch trugen die zahlreichen gemeinsamen Diskussionen maßgeblich zum Gelingen dieser Arbeit bei und lenkten meinen Fokus immer wieder auf das Wesentliche zurück. Auch für die Betreuung der Arbeit und die Mitwirkungen an den Manuskripten gilt mein Dank. Für Ihren Beitrag zu den Artikeln bedanke ich mich ebenso bei allen Co-Autoren. Hier sind insbesondre noch Prof. Dr. Oliver Gailing, Prof. Dr. Konstantin Krutovsky und Herr Dr. Markus Müller zu nennen, die durch die umfangreichen und detailreichen Durchsichten der Manuskripte und den zahlreichen fachlichen Impulsen und Gesprächen zum Gelingen beitrugen. Prof. Dr. Niko Balkenhol und Prof. Dr. Christian Ammer sind für Ihren fachlichen Rat und die Unterstützung bei der Formulierung der Forschungsfragen zu nennen. Ebenfalls möchte ich Ihnen, neben Herrn PD. Dr. Leinemann und Prof. Dr. Gailing, für die Betreuung und Bewertung der Arbeit danken. Die erfolgreiche Durchführung der Arbeit wäre auch ohne das Laborpersonal der Abteilung Forstgenetik und Forstpflanzenzüchtung nicht möglich gewesen. Hier möchte ich insbesondere Frau Christine Radler und Frau Oleksandra Dolynska ganz herzlich danken. Durch euch habe ich einen sehr guten Einstieg in die Laborarbeit erhalten. Danke auch für das reichliche Engagement, mit dem ihr viele der anfallenden Laboruntersuchungen durchgeführt habt. Auch möchte ich mich auch bei allen Kollegen der Abteilung für das angenehm freundschaftliche Klima bedanken. Ich freu mich Herrn Dr. Tim Pettenkoffer durch meine Tätigkeit kennengelernt zu haben, du warst einfach der beste Mitdoktorant und Bürokollege. Frau Regina Berkeley und Frau Lioba Degenhardt möchte ich für die viel Hilfe mit den Wirren der Verwaltung danken. Herrn Dr. Bernhard Hosius, Herrn Dr. Harald Koss und Herrn Fritz von Baumbach, bei euch möchte ich mich für die geniale Probennahmen bedanke. Die gute Gesellschaft und zahlreichen Gespräche und Diskussionen trugen immer zur lockeren Atmosphäre bei den Dienstreisen bei. Herrn Christian Rössner möchte ich für sein Engagement bei der Überwindung mehrere Widerlichkeiten für die Bereitstellung der Einzelbaumabsaaten aus Thüringen danken. Herrn Dr. Aki Höltken und Herrn Sergej Havel ermöglichten die Verwendung der Proben der Harzer Hochlagenfichten und organisierten den schönen Ausflug zur Bestandesbegehung am Brocken. Besondere Dank gebührt auch Prof. Dr. Martin Ziehe, ohne seine Leidenschaft zur Wissensvermittlung mein Weg nicht in die Forstgenetik geführt hätte. Pauline, dir bin ich weit über diese Arbeit hinaus dankbar und glücklich, dass du meinen Lebensweg begleitest und bereicherst. 
CV

Oliver Caré

Birthplace: Munich, Germany

\title{
Academic education
}

\author{
Research associate \\ Department of Forest Genetics and Forest Tree \\ Breeding \\ Faculty of Forest Sciences and Forest Ecology \\ Georg-August-University Göttingen \\ M.Sc. Forestry Sciences and Forest Ecology \\ Faculty of Forest Sciences and Forest Ecology \\ Georg-August-University Göttingen
B.Sc. Forestry Science and Resource Management
TUM School of Life Sciences Weihenstephan
Technische Universität München

\section{Publications}

Stiegler, J., Wasner, A., Caré, O., Stimm, B., Binder, F. Anzucht von Baumarten im Quell- und Hartwandtopf - ein Vergleich. AFZ-DerWald 201721

Caré, O.; Müller, M.; Vornam, B.; Höltken, A.; Kahlert, K.; Krutovsky, K.; Gailing, O.; Leinemann, L. High morphological differentiation in crown architecture contrasts with low population genetic structure of German Norway spruce stands. Forests 2018, 9, 752, doi:10.3390/f9120752.

Gailing, O.; Kostick, S.; Caré, O.; Khodwekar, S. Leaf morphological and genetic variation between Quercus rubra and Quercus ellipsoidalis: Comparison of sympatric and parapatric populations. Ann. For. Res. 2018, 61, 81-94, doi:10.15287/afr.2018.1020.

Caré, O.; Gailing, O.; Müller, M.; Krutovsky, K. V.; Leinemann, L. Crown morphology in Norway spruce (Picea abies [Karst.] L.) as adaptation to mountainous environments is associated with single nucleotide polymorphisms (SNPs) in genes regulating seasonal growth rhythm. Tree Genetics and Genomes 2020, 16:4. doi: 10.1007/s11295-019-1394-x

Caré, O.; Gailing, O.; Müller, M.; Krutovsky, K. V.; Leinemann, L. Assoziation zwischen Kandidatengenen und der Kronenform der Fichte (Picea abies [L.] KARST.) zeigt die Klimaadaption autochthoner Hochlagenbestände. In Liesebach, M. (Ed.), Forstpflanzenzüchtung für die Praxis: 6. Tagung der Sektion Forstgenetik/ Forstpflanzenzüchtung vom 16. bis 18. September 2019 in Dresden. Tagungsband. Braunschweig: Johann Heinrich von Thünen-Institut, 296p, Thünen Rep 2020, 76, pp. 72-80.

Caré, O.; Gailing, O.; Müller, M.; Krutovsky, K. V.; Leinemann, L. Mating system in a native Norway spruce (Picea abies [L.] KARST.) stand - Relatedness and effective pollen population size show an association with the germination percentage of single tree progenies. Diversity 2020, 12, 266. 